MLCW MEY

REOPTING O

-

tol

MOLUMIMEY

DOEIEIA-0608

REDTHE

October 199

QREENHOUSE

U1DTh GSE

1017

. TIIIU

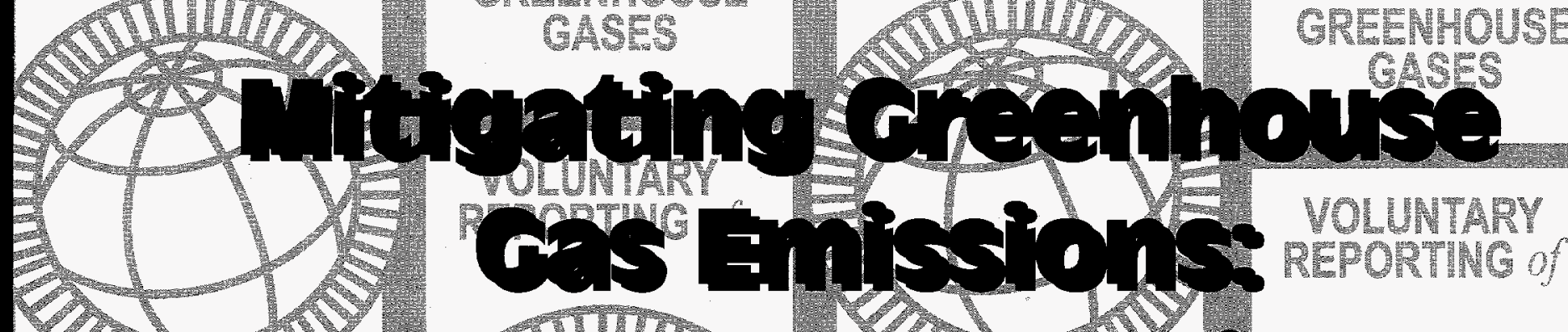

Q DIVII

GREENHOUSE CASES

MOLUNTARY REPORTING of

11120

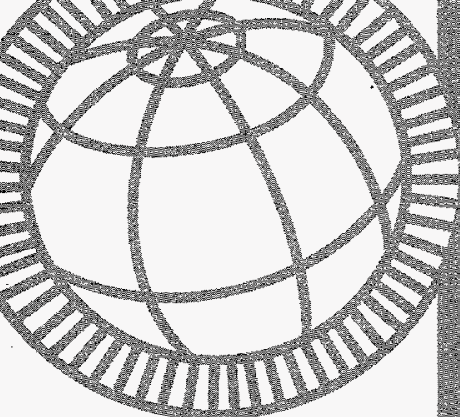

GREENHOUSE GASES

VOLUNTARY REPORTING of

11117

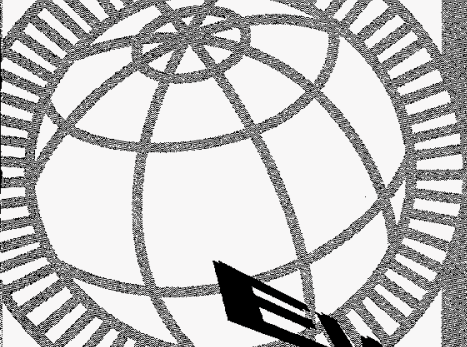

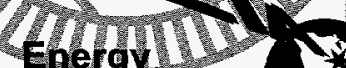
Energy GRpformations

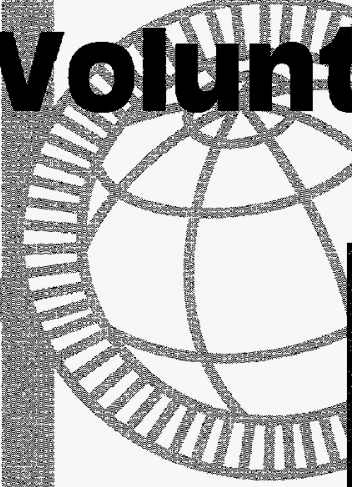

GREENHO

GASES

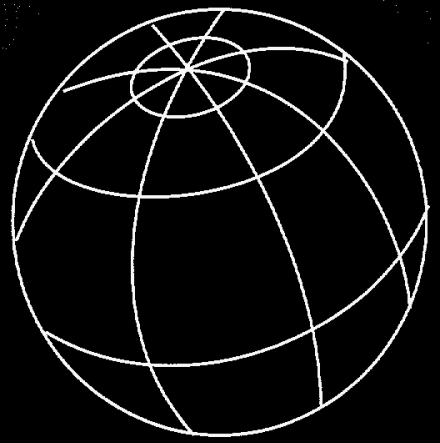

\section{VOLUNTARY REPORTING of}

QASES

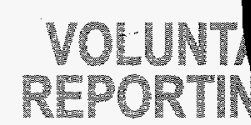

11112

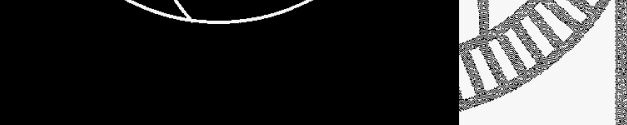

1428

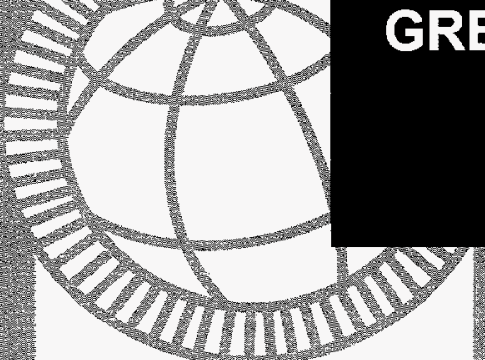
CASES

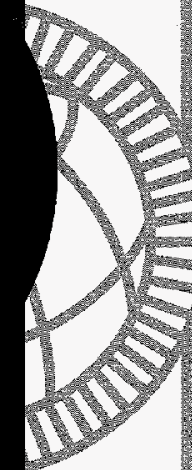

GREENHOUSE GASES

VOLUNTARY

REPORTING of

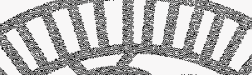

111172

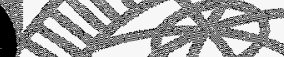

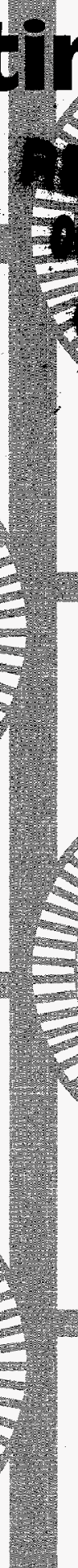

(6)

(1) -12

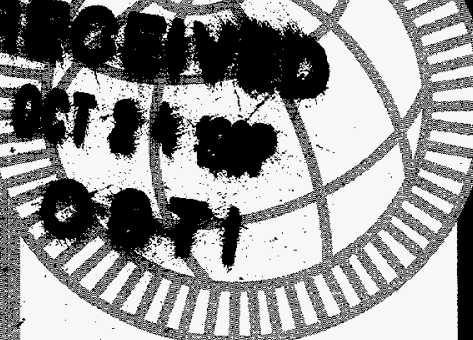

GRENHOUSE GASES

MOLUNARY
REPORTMG of

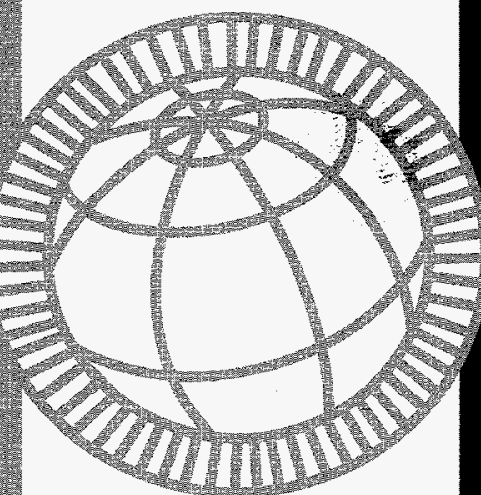

CPEMHOHSE GESES

VOLUNTARY REPORTING of 


\section{HOW TO OBTAIN EIA PRODUCTS AND SERVICES}

For further information on any of the following services, or for answers to energy information questions, please contact EIA's National Energy Information Center:
National Energy Information Center (NEIC)
(202) 586-8800
Energy Information Administration
(202) 586-0727 (fax)
Forrestal Building, Room 1F-048
TTY: (202) 586-1181
Washington, DC 20585
E-mail: infoctr@eia.doe.gov

\section{Electronic Products and Services}

EIA's Internet Site Services offer nearly all ElA publications. Users can view and download selected pages or entire reports, search for information, download EIA data and analysis applications, and find out about new EIA information products and services.

\section{World Wide Web: http://www.eia.doe.gov \\ Gopher: gopher://gopher.eia.doe.gov \\ FTP: ftp://ftp.eia.doe.gov}

EIA also offers a listserve service for EIA press releases and other short documents. Sign up on the EIA World Wide Web site.

EIA's CD-ROM, Energy InfoDisc, contains most EIA publications, several databases, and an energy forecasting model. The Energy InfoDisc, produced quarterly, is available for a fee from STAT-USA, Department of Commerce, 1-800-STAT-USA.

The Comprehensive Oil and Gas Information Source (COGIS), a bulletin board service, contains data files from most of EIA's oil- and gas-related reports. It is available for a fee from STAT-USA, on 1-800-STAT-USA.

EIA's Electronic Publishing System (EPUB) bulletin board contains data files, directories, and forecasts from most EIA reports. It can be accessed free of charge by dialing (202) 586-2557.

Many of EIA's data files and modeling programs are available for sale on diskette, tape, or cartridge, through either the National Technical Information Service or the Office of Scientific and Technical Information, Department of Energy. Contact NEIC for information on specific products, sources, and media, and ordering instructions.

\section{Printed Publications}

EIA directories are available free of charge from NEIC. Recent EIA periodicals and other publications are available from the Government Printing Office. Older reports are available from the National Technical Information Service:

\author{
Superintendent of Documents \\ U.S. Government Printing Office \\ P.O. Box 371954 \\ Pittsburgh, PA 15250-7954 \\ (202) 512-1800; (202)-512-2250 (fax)
}

\author{
National Technical Information Service \\ U.S. Department of Commerce \\ 5285 Port Royal Road \\ Springfield, VA 22161 \\ (703) 487-4650; (703) 321-8547 (fax)
}


DOE/EIA-0608(96)

Distribution Category UC-950

\title{
Mitigating Greenhouse Gas Emissions: Voluntary Reporting
}

\author{
October 1997
}

\author{
Energy Information Administration \\ Office of Integrated Analysis and Forecasting \\ U.S. Department of Energy \\ Washington, DC 20585
}

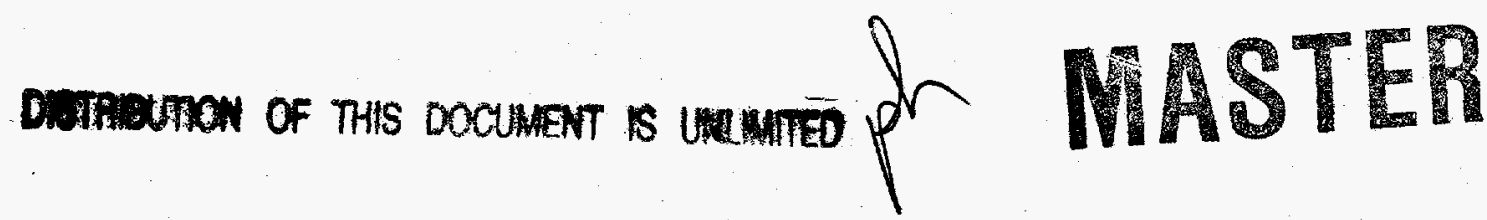

This report was prepared by the Energy Information Administration, the independent statistical and analytical agency within the Department of Energy. The information contained herein should not be construed as advocating or reflecting any policy position of the Department of Energy or of any other organization. 


\section{For More Information}

Individuals or members of organizations wishing to report reductions in emissions of greenhouse gases under the auspices of the Voluntary Reporting Program can contact the Energy Information Administration (EIA) at:

Voluntary Reporting of Greenhouse Gases Energy Information Administration

U.S. Department of Energy

Forrestal Building

EI-81, Room 2F-081

1000 Independence Avenue, SW

Washington, DC 20585

Telephone: 1-800-803-5182 or 202-586-0688

FAX: 202-586-3045

e-mail: infoghg@eia.doe.gov
The EIA has both a long form (EIA-1605) and a short form (EIA-1605EZ) available, as well as an electronic version of the form. They are available upon request or on EIA's web site at www.eia.doe.gov/oiaf/1605/ frntend.html.

General or specific technical information concerning the contents of this report may also be obtained by contacting the Voluntary Reporting Program. 


\section{DISCLAIMER}

This report was prepared as an account of work sponsored by an agency of the United States Government. Neither the United States Government nor any agency thereof, nor any of their employees, make any warranty, express or implied, or assumes any legal liability or responsibility for the accuracy, completeness, or usefulness of any information, apparatus, product, or process disclosed, or represents that its use would not infringe privately owned rights. Reference herein to any specific commercial product, process, or service by trade name, trademark, manufacturer, or otherwise does not necessarily constitute or imply its endorsement, recommendation, or favoring by the United States Government or any agency thereof. The views and opinions of authors expressed herein do not necessarily state or reflect those of the United States Government or any agency thereof. 


\section{DISCLAMIIXR}

Portions of this document may be illegible in electronic image products. Images are produced from the best available original document. 


\section{Preface}

Title XVI, Section 1605(b) of the Energy Policy Act of 1992 (EPACT), enacted on October 24, 1992, directed the Energy Information Administration (EIA) to establish a mechanism for "the voluntary collection and reporting of information on ... annual reductions of greenhouse gas emissions and carbon fixation achieved through any measures, including fuel switching, forest management practices, tree planting, use of renewable energy, manufacture or use of vehicles with reduced greenhouse gas emissions, appliance efficiency, methane recovery, cogeneration, chlorofluorocarbon capture and replacement, and power plant heat rate improvement ...."

The legislation further instructed EIA to create forms for the reporting of greenhouse gas emissions and reductions, and to establish a database of the information voluntarily reported under this subsection of EPACT. The reporting Forms EIA-1605 and EIA-1605EZ, "Voluntary Reporting of Greenhouse Gases," were first made available to the public in July 1995, providing a vehicle for voluntary reporting on activities that occurred before and during 1994. This publication summarizes data reported for 1995, the second year of data collection for the Voluntary Reporting of Greenhouse Gases Program.

The data reported to the program are available through several media. All nonconfidential reports received by the program are compiled into a public-access database, available either on CD-ROM or a set of diskettes. The software is interactive and modular by design, allowing the user to select, view, and if desired print the reports filed by the voluntary reporters, for each year of their participation. Predesigned queries allow the user to access and print a variety of summary reports; the user can also build original queries with commercially available SQL software.

The Public Use Database and the current reporting software are also available at the program's FTP (File Transfer Protocol) site on the World Wide Web. The site is: ftp://ftp.eia.doe.gov/pub/oiaf/1605/cdrom. Interested parties are encouraged to visit the Program's home page at http://www.eia.doe.gov/oiaf/1605/frntend.html for more information and background on the Program. Software, additional copies of this report, paper reporting forms, and technical support information can be obtained from the Voluntary Reporting of Greenhouse Gases Communications Center by e-mail at infoghg@ eia.doe.gov, toll-free at 1-800-803-5182, or locally at 202-586-0688.

This report was prepared under the guidance of Mary J. Hutzler, Director of EIA's Office of Integrated Analysis and Forecasting. People who have made significant contributions to the program, the current software, and the preparation of this report include: Arthur $\mathrm{T}$. Andersen, Director of the Energy Demand and Integration Division, Stephen Calopedis, Laura Gehlin, William LaPerch, Gabriela Martin, Kenneth Pruitt, Chris Minnucci, John Molineaux, Michael Mondshine, Richard Richards, and Arthur Rypinski.

EIA would also like to express special thanks to the voluntary reporters, without whom this program would be impossible. 



\section{Contents}

Executive Summary $\ldots \ldots \ldots \ldots \ldots \ldots \ldots \ldots \ldots \ldots \ldots \ldots \ldots \ldots \ldots \ldots \ldots \ldots \ldots \ldots \ldots$

1. Voluntary Reporting of Emissions Reduction Actions: An Overview $\ldots \ldots \ldots \ldots \ldots \ldots \ldots \ldots$

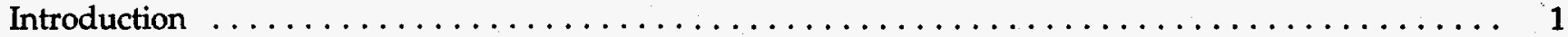

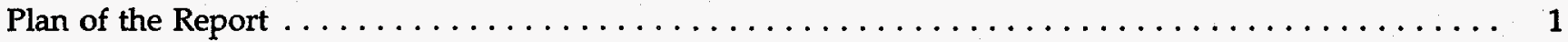

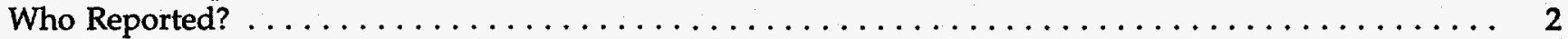

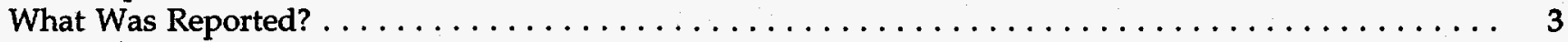

Emissions Mitigation Reporting in the Context of National Emissions Trends . . . . . . . . . . 7

2. Reducing Emissions from Electricity Supply $\ldots \ldots \ldots \ldots \ldots \ldots \ldots \ldots \ldots \ldots \ldots \ldots \ldots \ldots \ldots$

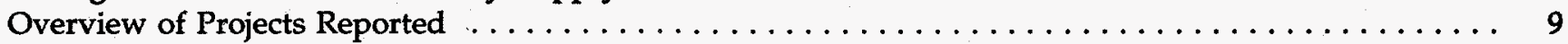

Reducing the Carbon Content of Energy Sources $\ldots \ldots \ldots \ldots \ldots \ldots \ldots \ldots \ldots \ldots \ldots$

Increasing Efficiency in Electricity Production and Distribution $\ldots \ldots \ldots \ldots \ldots \ldots \ldots \ldots \ldots$

Federal Voluntary Programs for the Electric Utility Industry $\ldots \ldots \ldots \ldots \ldots \ldots \ldots \ldots \ldots \ldots$

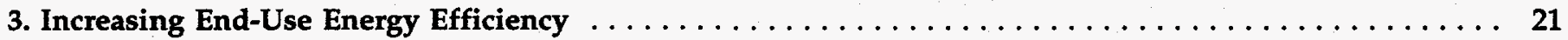

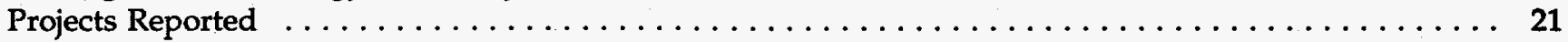

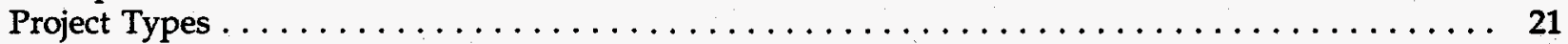

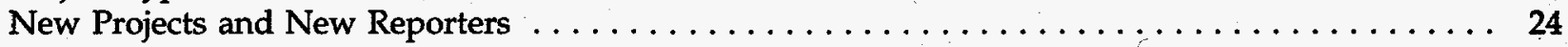

Federal Voluntary Programs To Increase End-Use Energy Efficiency $\ldots \ldots \ldots \ldots \ldots \ldots \ldots \ldots \ldots \ldots 27$

4. Reducing Oil-Based Transportation Fuel Use $\ldots \ldots \ldots \ldots \ldots \ldots \ldots \ldots \ldots \ldots \ldots \ldots \ldots \ldots \ldots$

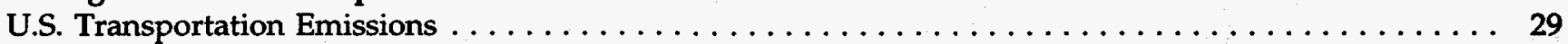

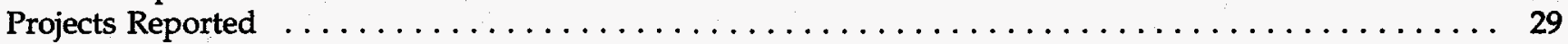

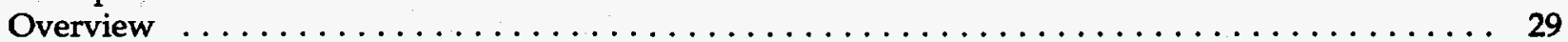

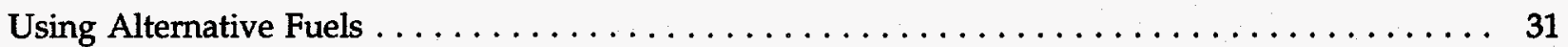

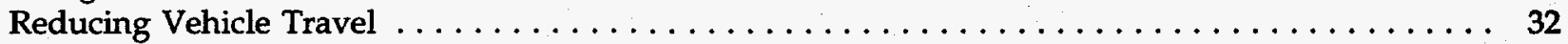

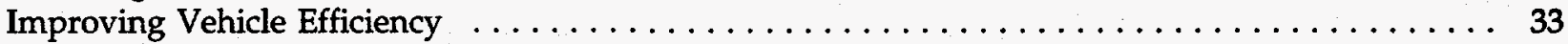

Federal Voluntary Programs for the Transportation Sector $\ldots \ldots \ldots \ldots \ldots \ldots \ldots \ldots \ldots \ldots \ldots \ldots$

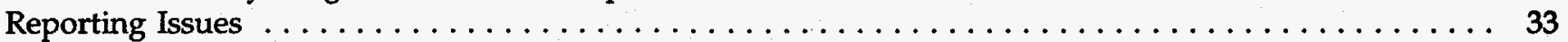

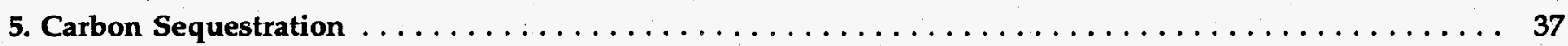

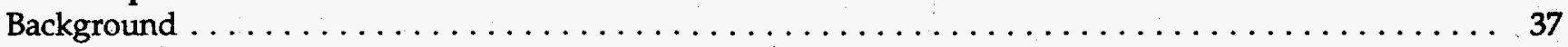

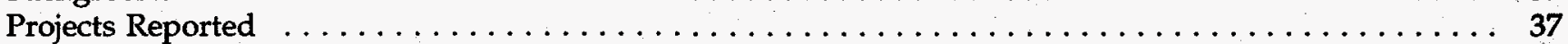

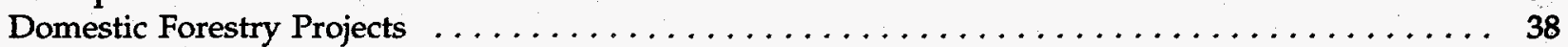

International Forestry Projects $\ldots \ldots \ldots \ldots \ldots \ldots \ldots \ldots \ldots \ldots \ldots \ldots \ldots \ldots \ldots$

Urban Forestry Projects $\ldots \ldots \ldots \ldots \ldots \ldots \ldots \ldots \ldots \ldots \ldots \ldots \ldots \ldots \ldots \ldots \ldots$

Federal Voluntary Carbon Sequestration Programs $\ldots \ldots \ldots \ldots \ldots \ldots \ldots \ldots \ldots \ldots \ldots \ldots \ldots \ldots .45$

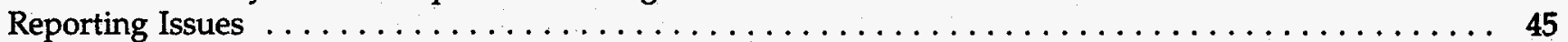


6. Projects To Reduce Methane Emissions $\ldots \ldots \ldots \ldots \ldots \ldots \ldots \ldots \ldots \ldots \ldots \ldots \ldots \ldots \ldots \ldots \ldots \ldots$

U.S. Methane Emissions in Perspective . . . . . . . . . . . . . . . . . . . . . . . . . . 49

Projects Reported $\ldots \ldots \ldots \ldots \ldots \ldots \ldots \ldots \ldots \ldots \ldots \ldots \ldots \ldots \ldots \ldots \ldots \ldots \ldots \ldots \ldots$

Emissions Reductions by Source $\ldots \ldots \ldots \ldots \ldots \ldots \ldots \ldots \ldots \ldots \ldots \ldots \ldots \ldots \ldots \ldots \ldots \ldots \ldots$

Methane Emissions from Waste Generation and Disposal .................. 50

Methane Emissions from Energy Production and Distribution: Natural Gas Systems . . . . . . 53

Methane Emissions from Energy Production and Distribution: Coal Mining . . . . . . . . . 54

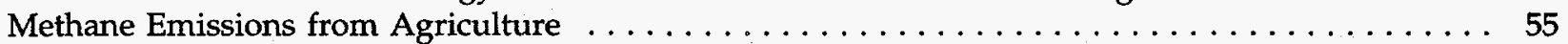

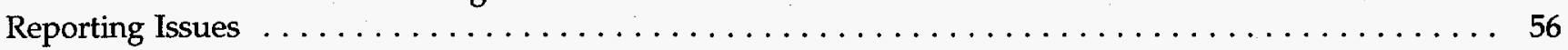

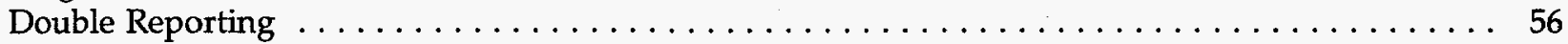

Methane Recovery as a Proxy for Emissions Reductions $\ldots \ldots \ldots \ldots \ldots \ldots \ldots \ldots \ldots \ldots$

The Role of Carbon Sequestered in Waste in the Global Carbon Cycle . . . . . . . . . . . . 56

7. Halogenated Substances and Other Gases $\ldots \ldots \ldots \ldots \ldots \ldots \ldots \ldots \ldots \ldots \ldots \ldots \ldots \ldots \ldots \ldots$

U.S. Emissions of Halogenated Substances and Other Gases in Perspective . . . . . . . . . . . . 59

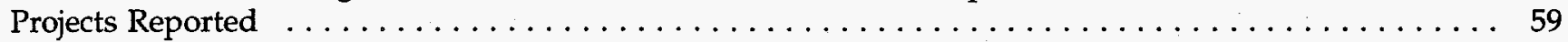

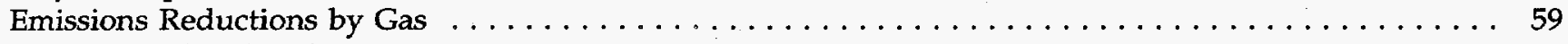

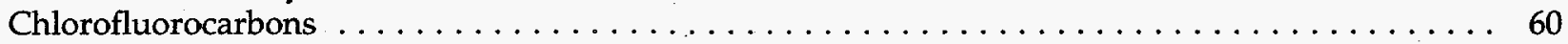

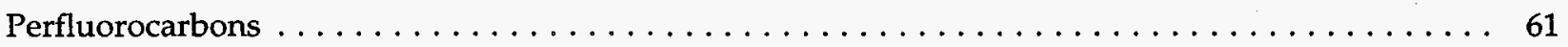

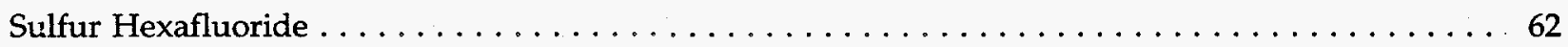

8. Entity-Level Emissions and Future Commitments $\ldots \ldots \ldots \ldots \ldots \ldots \ldots \ldots \ldots \ldots \ldots \ldots \ldots \ldots \ldots$

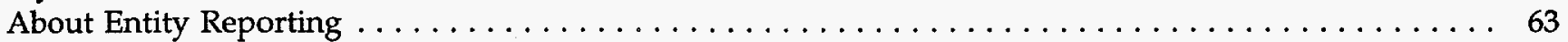

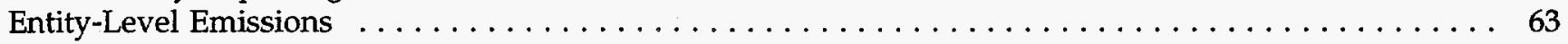

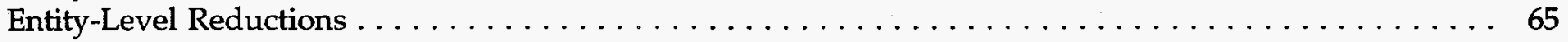

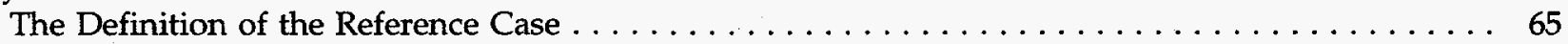

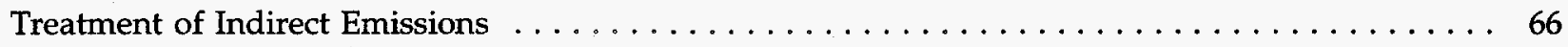

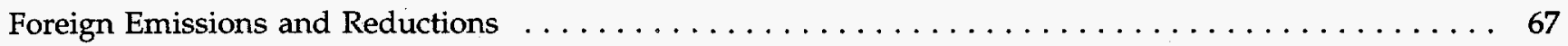

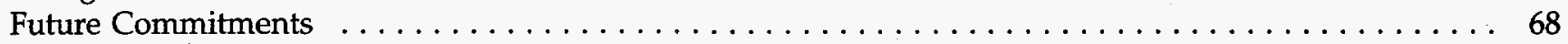

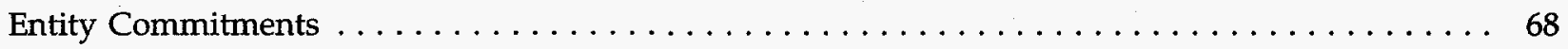

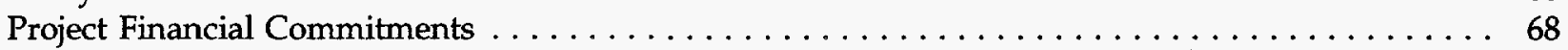

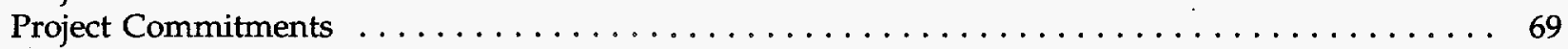

\section{Appendixes}

A. The Voluntary Reporting Program: A Developmental Overview $\ldots \ldots \ldots \ldots \ldots \ldots \ldots \ldots \ldots \ldots 71$

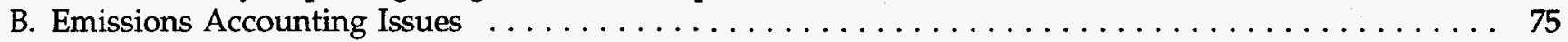

C. Summary of Reports Received $\ldots \ldots \ldots \ldots \ldots \ldots \ldots \ldots \ldots \ldots \ldots \ldots \ldots \ldots \ldots \ldots \ldots \ldots$

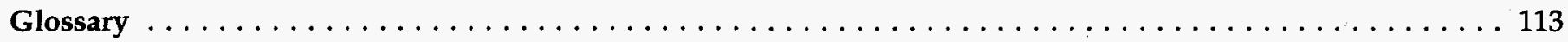

\section{Tables}

ES1. Profile of Voluntary Reporting Program Reports . . . . . . . . . . . . . . . . . .

1. Forms Filed, by Standard Industrial Classification and Data Year, 1994 and 1995 . . . . . . . . . . . 3

2. Distribution of Projects by Reduction Objective and Project Type, Data Year $1995 \ldots \ldots \ldots \ldots \ldots \ldots$

3. Geographic Scope of Reports Received and Location of Emissions Reductions Projects, Data Years 1994 and 1995

4. Summary of Project-Level Emissions Reductions and Carbon Sequestration by Reduction Objective,

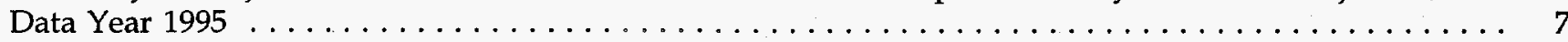

5. Number of Projects and Carbon Dioxide Emissions Reductions for Transportation Projects

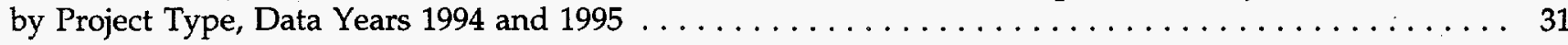

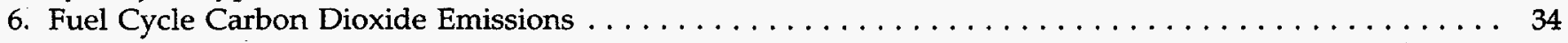

7. Electricity Supply Requirements for Recent Electric Vehicle Models $\ldots \ldots \ldots \ldots \ldots \ldots \ldots \ldots \ldots .34$ 
8. Estimated U.S. Emissions of Carbon Dioxide and Methane, 1990-1995 . . . . . . . . . . . . . . . 49

9. Total Reported Methane Emissions Reductions, Data Years 1991-1995 . . . . . . . . . . . . . . 50

10. Reported Methane Emissions Reductions from Waste Generation and Disposal Projects, Data Years 1991-1995 . . . . . . . . . . . . . . . . . . . . . . . . . . . . . . . 51

11. Reported Methane Emissions Reductions from Natural Gas System Projects, Data Years 1991-1995 . . . 53

12. Estimated U.S. GWP-Weighted Emissions of Greenhouse Gases, 1990-1995 . . . . . . . . . . . . . . . . . 59

13. Reported Halocarbon Emissions Reductions, Data Years $1991-1995 \ldots \ldots \ldots \ldots \ldots \ldots \ldots \ldots \ldots$

14. Reported Increases in Emissions of CFC Substitutes, Data Years $1991-1995 \ldots \ldots \ldots \ldots \ldots \ldots \ldots$

15. Reported U.S. Entity-Level Carbon Dioxide Emissions by Type of Activity, 1988-1995 . . . . . . . . . 64

16. Reported U.S. Entity-Level Emissions of Other Greenhouse Gases, 1988-1995 . . . . . . . . . . . . . . 65

17. Reported U.S. Entity-Level Carbon Dioxide Emissions Reductions by Type of Activity, 1991-1995 . . . 66

18. Reported 1990 and 1995 Carbon Dioxide Emissions for Selected Reporters

Using a "Basic Reference Case" . . . . . . . . . . . . . . . . . . . . . . . . . 67

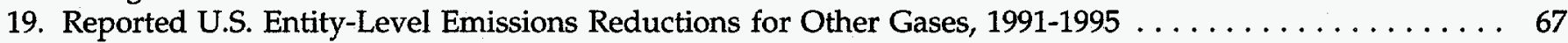

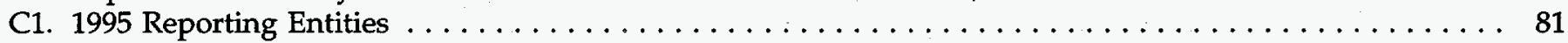

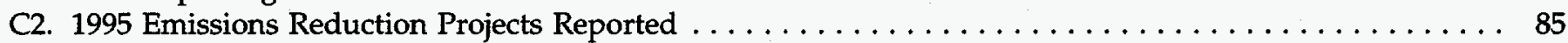

C3. Reporting Entities by Type of Form and Organization, Data Years 1994 and $1995 \ldots \ldots \ldots \ldots \ldots$. . . . 109

C4. Summary of Reports Received by Schedule, Data Years 1994 and 1995 . . . . . . . . . . . . . . . . . 109

C5. Distribution of Projects Reported by Project Type Category, Data Years 1994 and 1995 . . . . . . . . 110

C6. Distribution of Projects Reported by Project Type Category and Reporting Form, Data Year 1995 . . . 110

C7. Affiliation of Reported Emissions Reduction and Carbon Sequestration Projects with Voluntary Programs by Project Type Category, Data Year 1995

\section{Figures}

ES1. Project-Level Emissions Reductions Reported to the Voluntary Reporting Program, 1994 and 1995 . . . . x

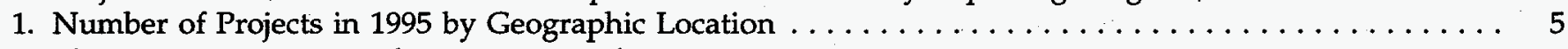

2. Electricity Emissions Reduction Projects by Project Size $\ldots \ldots \ldots \ldots \ldots \ldots \ldots \ldots \ldots \ldots \ldots$

3. Carbon Content Reduction Projects by Project Type $\ldots \ldots \ldots \ldots \ldots \ldots \ldots \ldots \ldots \ldots \ldots \ldots \ldots$

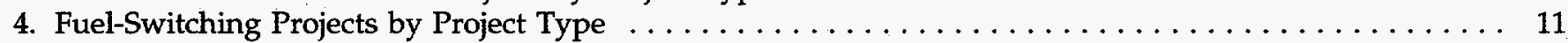

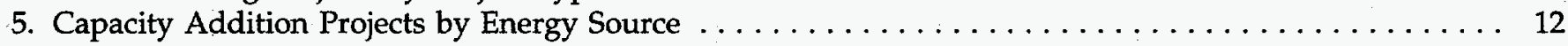

6. Efficiency Improvement Projects by Project Type $\ldots \ldots \ldots \ldots \ldots \ldots \ldots \ldots \ldots \ldots \ldots \ldots \ldots \ldots \ldots$

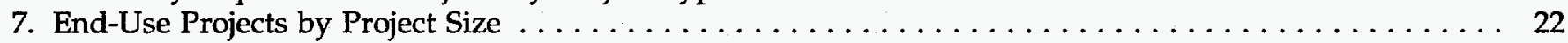

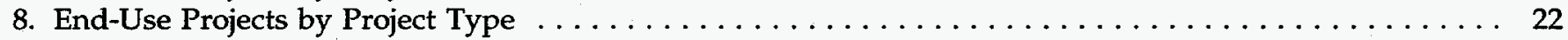

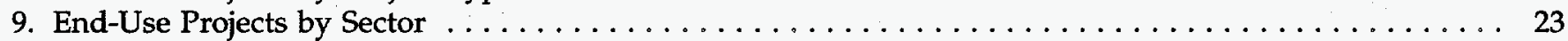

10. End-Use Projects by Load Shape Objective $\ldots \ldots \ldots \ldots \ldots \ldots \ldots \ldots \ldots \ldots \ldots \ldots \ldots \ldots \ldots \ldots 24$

11. Trends in Carbon Dioxide Emissions from the U.S. Transportation Sector, 1980-2015 . . . . . . . . . 29

12. Transportation Sector Carbon Emissions by Fuel, $1995 \ldots \ldots \ldots \ldots \ldots \ldots \ldots \ldots \ldots \ldots \ldots \ldots \ldots$

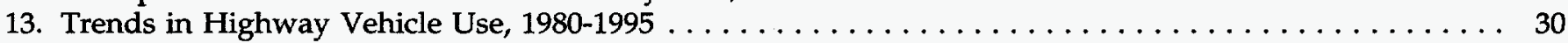

14. Transportation Sector Carbon Emissions Reduction Projects by Project Size and Type, 1995 . . . . . . 31

15. Comparison of Fuel Cycle Carbon Dioxide Emissions for Electric and Gasoline Vehicles . . . . . . . . 34

16. Carbon Sequestration Projects by Project Size $\ldots \ldots \ldots \ldots \ldots \ldots \ldots \ldots \ldots \ldots \ldots \ldots \ldots \ldots$

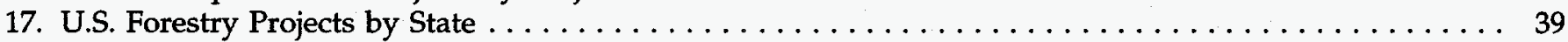

18. American Electric Power's Domestic Forestry Projects by Size . . . . . . . . . . . . . . 40

19. Total Sequestration for American Electric Power's Domestic Forestry Projects, 1992-1995 . . . . . . . . . 40

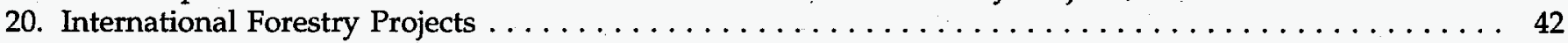

21. U.S. Urban Tree Planting Projects by State $\ldots \ldots \ldots \ldots \ldots \ldots \ldots \ldots \ldots \ldots \ldots \ldots \ldots \ldots \ldots \ldots \ldots . \ldots \ldots$

22. U.S. Methane Emissions by Source, 1990 and $1995 \ldots \ldots \ldots \ldots \ldots \ldots \ldots \ldots \ldots \ldots \ldots$ 



\section{Executive Summary}

The Voluntary Reporting Program, developed pursuant to Section 1605(b) of the Energy Policy Act of 1992, permits corporations, government agencies, households, and voluntary organizations to report on their emissions of greenhouse gases, and on actions taken that have reduced or avoided emissions or sequestered carbon, to the Energy Information Administration (EIA).

This, the second annual report of the Voluntary Reporting Program, describes information provided by the participating organizations on their aggregate emissions and emissions reductions, as well as their emissions reduction or avoidance projects, through 1995 . This information has been compiled into a database that includes reports from 142 organizations and descriptions of 967 projects that either reduced greenhouse gas emissions or sequestered carbon. Fifty-one reporters also provided estimates of emissions, and emissions reductions achieved, for their entire organizations.

The projects described actions taken to reduce emissions of carbon dioxide from energy production and use; to reduce methane and nitrous oxide emissions from energy use, waste management, and agricultural processes; to reduce emissions of halocarbons, such as CFCs and their replacements; and to increase carbon sequestration. Current reporters represent 13 different industries, as defined by the two-digit Standard Industrial Classification (SIC) code. More than 80 percent are electric utilities. Nonetheless, representation from other sectors is significant. Other reporters include large enterprises in the automotive, metals, chemicals, and computer industries.

In the past year, the prospect of global climate change and public policies to ameliorate climate change have received increasing attention from policymakers in Washington and from the public at large. Interest has been stimulated by the progress of the international climate change negotiations and the successive policy announcements of the U.S. Government, which have gradually committed the United States to a long-term strategy aimed at limiting U.S. emissions of greenhouse gases over the next two decades. The methods by which such a strategy might be implemented, however, have not been decided, and they remain a topic of active discussion.
To date, U.S. policy initiatives to promote progress toward the goal of stabilizing U.S. greenhouse gas emissions have emphasized voluntary efforts. President Clinton's Climate Change Action Plan (CCAP) sought to energize cooperative approaches to identify and implement actions that could reduce emissions of greenhouse gases. In that spirit, an array of government-industry partnerships were formed to search for and pursue opportunities to mitigate greenhouse gas emissions. Most Voluntary Reporting Program participants are also affiliated with one or more governmentsponsored voluntary programs.

Table ES1 indicates the number of contributors to the Voluntary Reporting Program for 1994 and 1995. The number of reports received increased by 31 percent, to 142. The number of individual projects described increased by 50 percent, to 967 . Reporters claimed that the 967 projects reduced emissions by a total of $184 \mathrm{mil}-$ lion metric tons of carbon dioxide equivalent in 1995 (Figure ES1).

Electricity supply projects were the most numerous of all projects reported under the Voluntary Reporting

\section{Figure ES1. Project-Level Emissions Reductions Reported to the Voluntary Reporting Program, 1994 and 1995}

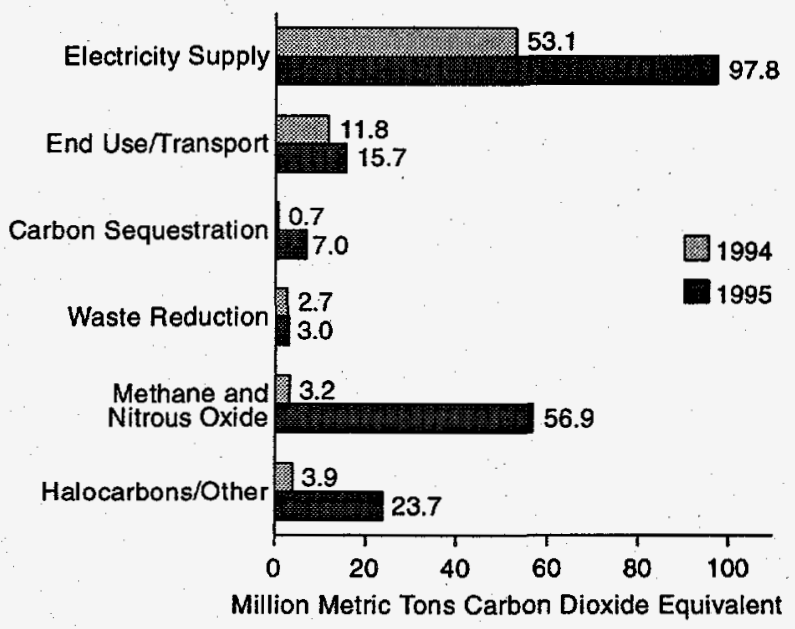

Source: Energy Information Administration, Forms EIA-1605 and EIA-1605EZ, "Voluntary Reporting of Greenhouse Gases." 
Table ES1. Profile of Voluntary Reporting Program Reports

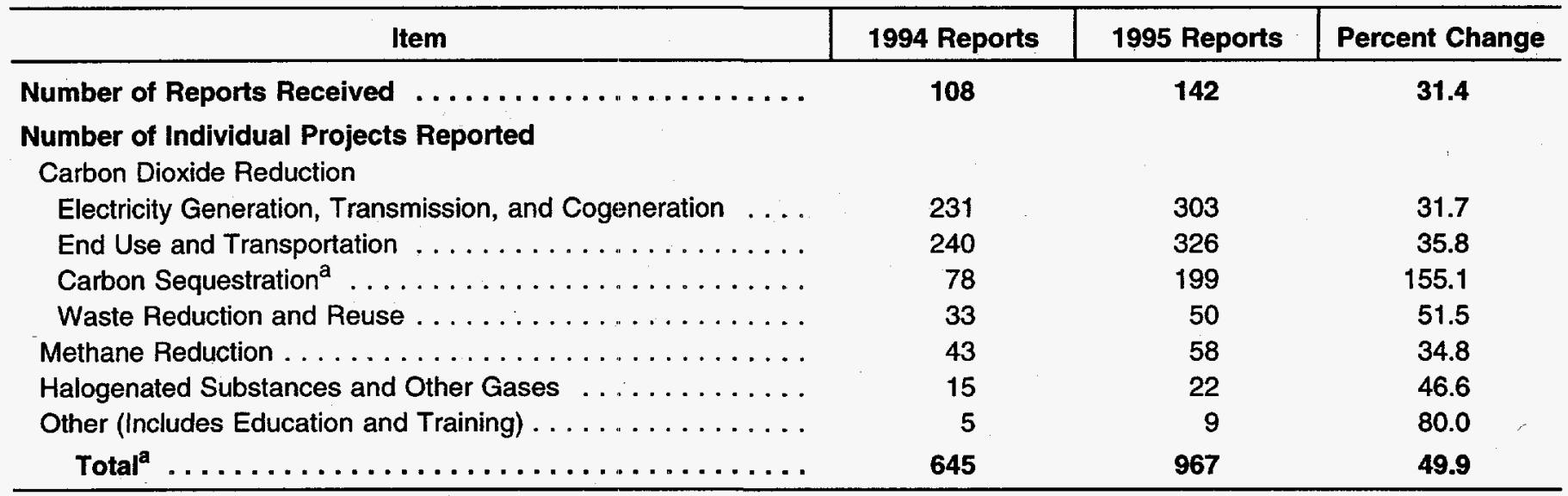

ancludes reports from 20 participants on their pro-rated shares of joint international forestry projects.

Source: Energy Information Administration, Forms EIA-1605 (long form) and EIA-1605EZ (short form), "Voluntary Reporting of Greenhouse Gases" (1994 and 1995 data from the 1995 and 1996 reporting cycles).

Program. Such projects can reduce emissions in two ways: replace high emitting fuels with lower emitting or non-emitting energy sources for power generation; or improve the efficiency of electricity generation and distribution to reduce energy use per unit of delivered electric power. Eighty-six organizations reported 303 electricity supply projects, one-half of which achieved carbon dioxide emissions reductions of 10,000 metric tons or more. More than one-third of the reductions came from 15 large electricity generation-related projects, which collectively reduced emissions by 79 million metric tons carbon dioxide equivalent, and most of which were nuclear availability improvement projects.

Ninety-one organizations reported 276 projects that improved energy end-use efficiency. Most reporters described electric utility demand-side management (DSM) programs. End-use projects tend to yield small reductions in carbon dioxide emissions; however, many (for example, installation of improved lighting or motor drive equipment) have the potential for widespread adoption.

Fifty transportation-related projects were reported. The most commonly reported transportation project was switching to alternative fuels, particularly compressed natural gas. However, there were several unusual transportation demand reduction projects. One company reported a half-million mile savings in employee commuting from the use of videoconferencing for regional meetings.

Almost 200 carbon sequestration projects were reported. Most States are benefiting from one or more projects sponsored by participants in the Voluntary Reporting Program. In addition, reported initiatives are underway in $\mathbf{1 5}$ foreign countries. Electric utilities are very active in supporting forestry projects. Their efforts are significantly complemented by a variety of nonprofit environmental protection organizations.

Emissions reductions for gases other than carbon dioxide accounted for 16 percent of the reported 1995 reductions (on a carbon dioxide equivalent basis). Coal mining companies reported initiatives to capture and use methane emissions from their operations; waste management organizations reported actions that captured methane from landfills and reduced waste accumulation that would otherwise have produced methane emissions in the future. One electric utility reported halving its emissions of sulfur hexafluoride-a gas that has a global warming potential of 23,900 . (For a discussion of global warming potential, see "What Are Greenhouse Gases?" on page 6.)

Fifty-one reporters provided information on their aggregate levels of both greenhouse gas emissions and reductions. These reporters collectively reported direct emissions of some 855 million metric tons and indirect emissions of 378 million metric tons carbon dioxide equivalent in 1995. They reported reductions of about 84 million metric tons carbon dioxide equivalent in 1995. Most reporters calculated their company-wide reductions based on what their emissions would have been if they had not undertaken actions tending to reduce their emissions. However, 10 firms reported reductions calculated on the basis that their emissions were lower than in some baseline year, usually 1990. For most reporters, increases in overall activity levels associated with economic growth have tended to offset improved emissions rates per unit of activity, leading to increases in emissions. These increases, however, are less than they would have been in the absence of their voluntary greenhouse gas reduction efforts. 


\section{Voluntary Reporting of Emissions Reduction Actions: An Overview}

\section{Introduction}

The Energy Policy Act of 1992 (EPACT) directed the Energy Information Administration (EIA) to develop two new programs to enhance understanding of U.S. emissions of greenhouse gases as well as the scope of efforts directed toward reducing emissions (see box on page 2). ${ }^{1}$ This report focuses on the second program, mitigation of emissions. ${ }^{2}$ It is based on a reporting system designed to document voluntary actions that reduce emissions of greenhouse gases or remove such gases from the atmosphere. The reporting program was developed in cooperation with the Department of Energy's Office of Policy and with the U.S. Environmental Protection Agency.

This report presents information on activities underway in 1995, which reflects the second year of data collection for the program. The database compilation includes reports from 142 volunteers and describes more than 900 projects that either reduce greenhouse gas emissions or sequester carbon. Projects relate to emissions of carbon dioxide from energy production and use; methane and nitrous oxide emissions from energy use, waste management, and agricultural processes; emissions involving a wide range of halocarbon use; and actions that increase carbon sequestration. Current reporters represent 13 different industries, as defined by the twodigit Standard Industrial Classification (SIC) code. More than 80 percent are electric utilities. Nonetheless, representation from other sectors is significant, including large enterprises in the automotive, metals, chemicals, and computer industries.

As concern about global climate change grows, the search for remediation options intensifies. Voluntary reporting of emissions mitigation initiatives can help identify innovative actions that can spur imitation and widespread replication across the economy. To the extent that achievements are realized in this voluntary manner, pressures for more direct action to control emissions may be ameliorated.

To date, U.S. policy initiatives to promote progress toward the goal of stabilizing U.S. greenhouse gas emissions have emphasized voluntary efforts. President Clinton's Climate Change Action Plan (CCAP) sought to energize cooperative approaches to identify and implement actions that could reduce emissions of greenhouse gases. ${ }^{3}$ In that spirit, an array of government/ industry partnerships were formed to search for and pursue opportunities to mitigate greenhouse gas emissions. Most of the contributors to the database on voluntary greenhouse gas emissions mitigation efforts are affiliated with one or more government-sponsored voluntary programs.

\section{Plan of the Report}

This report is divided into eight chapters. The remainder of this chapter provides an overview of participation in the Voluntary Reporting Program, a perspective on the composition of activities reported, and a review of some key issues in interpreting and evaluating achievements associated with reported emissions mitigation initiatives.

Chapters 2 through 7 provide a more detailed review of the variety of project-level emissions reduction initiatives reported to the program. Carbon dioxide emissions reductions are the focus of Chapters 2 through 4. Chapter 2 examines projects involving energy efficiency improvements in the production and distribution of electricity and reductions in the use of higher emitting carbon-based fuels. Chapter 3 considers improvements in end-use efficiency in the residential, commercial, and industrial sectors. Chapter 4 reviews transportation projects that reduce travel activity or diminish reliance on petroleum-based fuels. Activities to improve or

\footnotetext{
${ }^{1}$ Title XVI of the Energy Policy Act, Public Law 102-486 (October 24, 1992), in Section 1605(a) called for an annual report on national aggregate emissions of greenhouse gases. Section 1605 (b) called for the establishment of a database on annual reductions of emissions as reported on a voluntary basis.

${ }^{2}$ Since 1993, EIA has issued an annual report on aggregate U.S. emissions-Emissions of Greenhouse Gases in the United States-which deals with the first program.

${ }^{3}$ U.S. Department of State, Climate Action Plan, Publication 10496 (Washington, DC, July 1997 ).
} 


\section{The Energy Policy Act of 1992, Sections 1605(b) and (c)}

(B) Voluntary Reporting.-

(1) ISSUANCE OF GUIDELINES.-Not later than 18 months after the date of the enactment of this Act, the Secretary shall, after opportunity for public comment, issue guidelines for the voluntary collection and reporting of information on sources of greenhouse gases. Such guidelines shall establish procedures for the accurate voluntary reporting of information on-

(A) greenhouse gas emissions-

(i) for the baseline period of 1987 through 1990; and

(ii) for subsequent calendar years on an annual basis;

(B) annual reductions of greenhouse gas emissions and carbon fixation achieved through any measures, including fuel switching, forest management practices, tree planting, use of renewable energy, manufacture or use of vehicles with reduced greenhouse gas emissions, appliance efficiency, methane recovery, cogeneration, chlorofluorocarbon capture and replacement, and power plant heat rate improvement;

(C) reductions in greenhouse gas emissions achieved as a result of-

(i) voluntary reductions;

(ii) plant or facility closings; and

(iii) State or Federal requirements; and

(D) an aggregate calculation of greenhouse gas emissions by each reporting entity.
Such guidelines shall also establish procedures for taking into account the differential radiative activity and atmospheric lifetimes of each greenhouse gas.

(2) REPORTING PROCEDURES.-The Administrator of the Energy Information Administration shall develop forms for voluntary reporting under the guidelines established under paragraph (1), and shall make such forms available to entities wishing to report such information. Persons reporting under this subsection shall certify the accuracy of the information reported.

(3) CONFIDENTIALITY.-Trade secret and commercial or financial information that is privileged or confidential shall be protected as provided in section 552(b)(4) of title 5, United States Code.

(4) ESTABLISHMENT OF DATA BASE.-Not later than 18 months after the date of the enactment of this Act, the Secretary through the Administrator of the Energy Information Administration shall establish a data base comprised of information voluntarily reported under this subsection. Such information may be used by the reporting entity to demonstrate achieved reductions of greenhouse gases.

\section{(C) Consultation.-}

In carrying out this section, the Secretary shall consult, as appropriate, with the Administrator of the Environmental Protection Agency. expand carbon sinks, notably through reforestation and afforestation, are the subject of Chapter 5 . Emissions reduction initiatives associated with methane and halogenated substances are examined in Chapters 6 and 7, respectively.

Chapter 8 reviews emissions reports of participants who provided data on aggregate entity emissions. A total of 51 reporters provided information on both aggregate emissions and aggregate reductions. These include most of the largest electric utilities in the United States. Appendixes provide information on the development and structure of the data collection instrument, a discussion of issues in the interpretation of the data, and summary lists of reporters and projects reported.

\section{Who Reported?}

The data collection program for emissions mitigation actions is highly flexible. At one extreme, participants can limit their reporting to a single project. At the other extreme, a report can include multiple projects placed in the context of the reporter's aggregate or "entitylevel" emissions inventory.

Reports for 1995 were received from 142 participants in 13 different industries or services, compared with 108 reports from participants in nine different industries or services for 1994 (Table 1). Most reporters were utilities actively involved in the production and distribution of electricity. Electric utilities accounted for 81 percent (115) of the total number of reporting entities, 
Table 1. Forms Filed, by Standard Industrial Classification and Data Year, 1994 and 1995

(Number of Reports)

\begin{tabular}{|c|c|c|c|}
\hline \multirow[b]{2}{*}{ SIC Code } & \multirow[b]{2}{*}{ Description } & \multicolumn{2}{|c|}{ Data Year } \\
\hline & & 1994 & 1995 \\
\hline 08 & Forestry & 1 & 2 \\
\hline 12 & Coal Mining & 1 & 2 \\
\hline 27 & 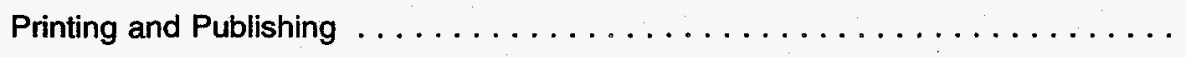 & 0 & 1 \\
\hline 28 & Chemical and Allied Products & 1 & 3 \\
\hline 33 & Primary Metals . . . . . . . . & 2 & 2 \\
\hline 34 & Fabricated Metal Products, Except Machinery and Transportation Equipment & 0 & 2 \\
\hline 36 & Electronic Equipment & 1 & 1 \\
\hline 37 & Transportation Equipment & 1 & 1 \\
\hline 38 & Miscellaneous Manufacturing Industries & 0 & 1 \\
\hline 49 & Electric, Gas, and Sanitary Services. & 98 & 123 \\
\hline 65 & Real Estate & 0 & 1 \\
\hline 82 & Educational Services & 1 & 2 \\
\hline 88 & Private Households & 2 & 1 \\
\hline Total & $\ldots \ldots$ & 108 & 142 \\
\hline
\end{tabular}

Source: Energy Information Administration, Forms EIA-1605 (long form) and EIA-1605EZ (short form), "Voluntary Reporting of Greenhouse Gases."

compared with 88 percent (96) during the previous reporting cycle. Of the 115 electric utility reporters to the Voluntary Reporting Program, 41 (36 percent) reported entity-wide information on emissions and reductions. Even though the number of reporters from other industries remained relatively small, in many cases reports were received from key companies in those industries. For example, the automotive products industry was represented by General Motors; the metals industry was represented by Noranda and an operating division of Alcan; Peabody reported on coal mining; and IBM represented the electronic equipment sector. A complete listing of all reporters is provided in Appendix C.

Most reporters indicated that their projects were affiliated with one or more government-sponsored voluntary programs. Of the projects reported, 721 were affiliated with the Climate Challenge Program, 29 with EPA's Green Lights Program, 19 with the U.S. Initiative on Joint Implementation, 13 with the Climate Wise Recognition Program, 9 with the Natural Gas STAR Program, and 8 each with the Landfill Methane Outreach and Energy Star Building Programs. Other voluntary programs cited included Energy Star Computers, Energy Star Transformers, the Voluntary Aluminum Industrial Partnership, Motor Challenge, Waste Wise, and Coalbed Methane Outreach.
Not all participants in the various voluntary programs provide information for the EIA database. The level of participation rose in the second reporting cycle, however, as familiarity with emissions accounting methodology improved, and as organizational efforts to promote accomplishments gained momentum.

\section{What Was Reported?}

Of the 142 reporters, 129 (91 percent) provided information on a total of 967 projects (931 domestic and 36 foreign), and 13 provided data on reduction accomplishments without providing specific information on project characteristics (Table 2 and Figure 1). The projects were widely distributed geographically within the United States. A limited number were located abroad, where several forestry initiatives are underway. The total number of projects reported increased by 322 , or 50 percent, compared with the previous reporting cycle (Table 3).

About one-third of all the projects reported were related to electricity generation, transmission, and distribution. More than 200 involved actions to improve power generation heat rates or to reduce energy losses associated with electricity transmission and distribution. 
Table 2. Distribution of Projects by Reduction Objective and Project Type, Data Year 1995

\begin{tabular}{|c|c|c|}
\hline Reduction Objective and Project Type & Number of Projects & Number of Reporters \\
\hline Electricity Generation, Transmission, and Distribution & 292 & 86 \\
\hline Cogeneration and Waste Heat Recovery $\ldots \ldots \ldots \ldots \ldots$ & 11 & 8 \\
\hline Energy End Use $\ldots \ldots \ldots \ldots \ldots \ldots \ldots \ldots \ldots \ldots$ & 276 & 91 \\
\hline Transportation and Offroad Vehicles $\ldots \ldots \ldots \ldots \ldots$ & 50 & 34 \\
\hline Waste Treatment and Disposal (Methane) & 39 & 20 \\
\hline Agriculture (Methane and Nitrous Oxide) $\ldots \ldots \ldots$ & 3 & 2 \\
\hline Oil and Natural Gas Systems and Coal Mining (Methane) . . . . . . & 16 & 10 \\
\hline Carbon Sequestration $\ldots \ldots \ldots \ldots \ldots \ldots \ldots \ldots \ldots$ & 199 & 62 \\
\hline
\end{tabular}

Note: The total number of reporters are smaller than the sum of the numbers of reporters for each project type, because most reporters provided information on more than one project.

Source: Energy Information Administration, Forms EIA-1605 and EIA-1605EZ, "Voluntary Reporting of Greenhouse Gases."

Table 3. Geographic Scope of Reports Received and Location of Emissions Reductions Projects, Data Years 1994 and 1995

\begin{tabular}{|c|c|c|c|c|}
\hline \multirow[b]{2}{*}{ Geographic Scope } & \multicolumn{2}{|c|}{ Reports Received } & \multicolumn{2}{|c|}{ Projects Reported } \\
\hline & 1994 & 1995 & 1994 & 1995 \\
\hline U.S. Only & 102 & 124 & 636 & 931 \\
\hline Foreign Only & 2 & 2 & 9 & 36 \\
\hline Both U.S. and Foreign . . . . . & 4 & 16 & NA & NA \\
\hline Total $\ldots \ldots \ldots \ldots \ldots \ldots \ldots \ldots \ldots \ldots \ldots$ & 108 & 142 & 645 & 967 \\
\hline
\end{tabular}

$\mathrm{NA}=$ not applicable.

Source: Energy Information Administration, Forms EIA-1605 and EIA-1605EZ, "Voluntary Reporting of Greenhouse Gases."

Another 100 projects involved increasing reliance on non-carbon or low-carbon fuels for generation. From an emissions standpoint, the largest reduction achievements came from improving nuclear plant availability so that coal-fired generation could be reduced. Other carbon-reducing projects included increased use of wind power and biomass for electricity generation.

Numerous projects (276) designed to improve energy end-use efficiency were also reported, most of them by electric utilities. They covered an array of demand-side management efforts to replace inefficient equipment and improve building shell integrity. Projects reported by industrial firms included motor drive replacement; integrated control of heating, cooling, and lighting systems; and cogeneration. Many utilities reported multiple projects affecting both supply and demand for energy. Only a limited number of reporters provided information on the costs and benefits of their actions; however, those that provided such information usually indicated a payback period of less than 2 years.

Among the remaining projects reported, those designed to improve carbon sinks were most numerous. A wide variety of forestry projects were identified. Of those initiated in the United States, 14 percent involved urban tree planting, and 54 percent involved reforestation or afforestation. One or more such projects were initiated in 41 States. Although utilities sponsored most of the projects, substantial activity was reported by nonprofit organizations. Thirty-six foreign forestry initiatives were also reported, involving 15 countries (Table 3 ). 
Figure 1. Number of Projects in 1995 by Geographic Location

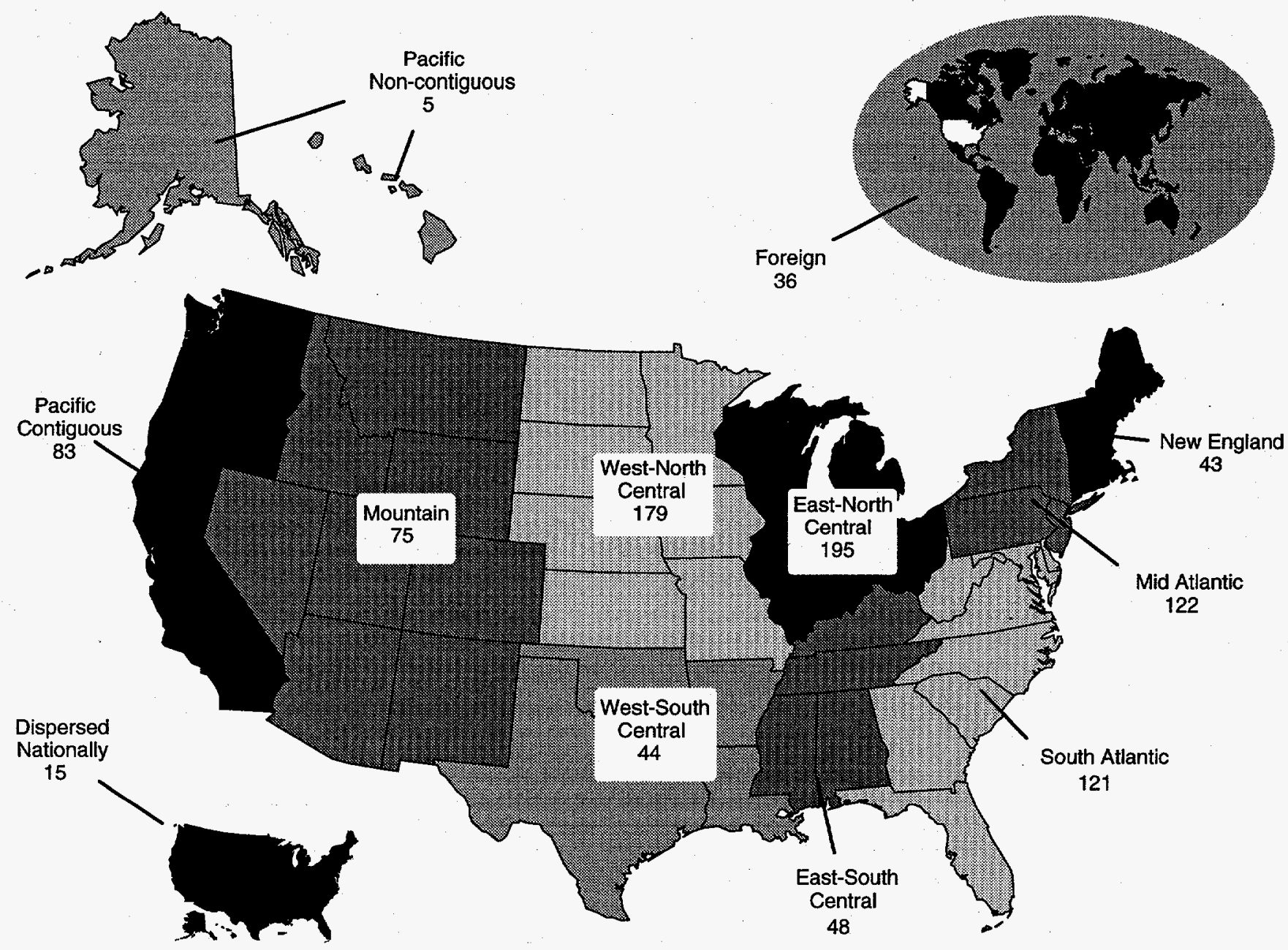

Notes: Fractions of projects dispersed across regions were allocated to the individual regions. As a result, the regional values do not add to the total number of projects reported (967) due to rounding. Of the 36 foreign projects reported, 20 represent shares in the Rio Bravo Carbon Sequestration Pilot Project.

Source: Energy Information Administration, Forms EIA-1605 and EIA-1605EZ, "Voluntary Reporting of Greenhouse Gases."

Fifty projects affecting transportation fuel use were reported. Two-thirds promoted substitution of alternative fuels for gasoline. Natural gas conversions were the most numerous. From an emissions reduction perspective, the single largest project involved the replacement of conventional rail coal cars with lightweight aluminum cars, which enabled more coal to be shipped per trip. As a result, the number of deliveries and freight miles needed to service major coal-fired power facilities were reduced. The most comprehensive transportation project reported was developed by Quad/Graphics, which simultaneously incorporated decisions on plant location, alternate work schedules, car pooling, and mass transit development to minimize workforce commuting costs and related emissions.
A variety of efforts to reduce methane emissions and the emissions of other gases with high global warming potential were also reported. (For a discussion of global warming potential, see "What Are Greenhouse Gases?" on page 6.) Methane projects were numerous, with most capturing methane from waste in landfills, wastewater treatment, or animal husbandry. The recovered methane was typically combusted to supply electricity. The greatest methane emissions reductions were associated with a large waste diversion project. The Integrated Waste Services Association (IWSA) represents 65 of the Nation's 114 waste-to-energy facilities in operation in 1995. The IWSA reported reductions of 944,000 metric tons of carbon dioxide. Other initiatives were directed toward reducing fugitive emissions from 


\section{What Are Greenhouse Gases?}

Many chemicals found in the Earth's atmosphere act as "greenhouse gases," which received their appellation because they tend to be transparent to sunlight radiated largely in the visible and ultraviolet spectra, whereas they tend to absorb infrared radiation (heat) that is radiated back into the atmosphere from the Earth's surface. This process traps the heat from sunlight at, or close to, the Earth's surface and significantly raises the average temperature of the planet. Many gases that occur naturally in the atmosphere exhibit such "greenhouse" properties, including water vapor, carbon dioxide, methane, nitrous oxide, and an array of largely manufactured halogenated substances. Other gases have so-called "indirect effects" on global warming, because they may contribute to the buildup or decomposition of other greenhouse gases in the atmosphere. For instance, some urban air pollutants (nitrogen oxides and nonmethane volatile organic compounds) react in the presence of sunlight to create ozone $\left(\mathrm{O}_{3}\right)$, which is also a greenhouse gas. Sulfur dioxide may have a net cooling effect by promoting cloud formation, while chlorofluorocarbons and hydrochlorofluorocarbons have a direct warming effect that is offset to some unknown degree by an indirect cooling effect caused by their propensity to destroy ozone in the stratosphere.

Atmospheric concentrations of several important greenhouse gases (carbon dioxide, methane, nitrous oxide, and most halogenated substances) have been increasing rapidly for many years. The growth in their concentrations is believed to be caused by human activities-particularly, by the burning of fossil fuels and by deforestation. In recent years, some scientists and policymakers have become concerned that the buildup of greenhouse gases in the atmosphere may increase the share of the sun's heat retained in the atmosphere, which in turn may affect the Earth's climate in uncertain but potentially disruptive ways.

Some greenhouse gases are more effective in trapping reflected infrared radiation than others. Since policymakers need to know on which gases their efforts should be concentrated, scientists working with the Intergovernmental Panel on Climate Change (IPCC) have engaged in efforts to develop an index of the relative marginal heat-trapping capacities of various greenhouse gases. This index, called a "global warming potential" (GWP), is intended to measure only the marginal direct radiative forcing of greenhouse gases, ignoring most indirect effects, which proved too complex and uncertain to incorporate in the GWP measure. GWPs are calculated on the basis of the radiative forcing ability of a unit of carbon dioxide, which is set equal to 1 , integrated over periods of 20 , 100 , and 500 years.

The IPCC periodically revises its GWP calculations. The table below shows the most recent (1995) 100-year GWPs for some of the most important greenhouse gases. The IPCC indicates that the typical uncertainty for these estimates is \pm 35 percent.

\section{Numerical Estimates of 100-Year Global Warming Potential Relative to Carbon Dioxide (Carbon Dioxide $=1$ )}

\begin{tabular}{|c|c|}
\hline Gas & $\begin{array}{c}\text { 100-Year } \\
\text { Global Warming } \\
\text { Potential }\end{array}$ \\
\hline Carbon Dioxide . . . . . . . . & 1 \\
\hline Methane $\ldots \ldots \ldots \ldots \ldots$ & 21 \\
\hline Nitrous Oxide $\ldots \ldots \ldots \ldots \ldots$ & 310 \\
\hline \multicolumn{2}{|l|}{ Halogenated Substances } \\
\hline HFC-23 $\ldots \ldots \ldots \ldots \ldots$ & 11,700 \\
\hline HFC-32 $: \ldots \ldots \ldots \ldots \ldots$ & 650 \\
\hline HFC-41 $\ldots \ldots \ldots \ldots \ldots \ldots$ & 150 \\
\hline HFC-43-10mee . . . . . . . . . . & 1,300 \\
\hline HFC-125 $\ldots \ldots \ldots \ldots \ldots$ & 2,800 \\
\hline HFC-134 $\ldots \ldots \ldots \ldots \ldots$ & 1,000 \\
\hline HFC-134a $\ldots \ldots \ldots \ldots \ldots$ & 1,300 \\
\hline HFC-143 $\ldots \ldots \ldots \ldots \ldots$ & 300 \\
\hline HFC-143a $\ldots \ldots \ldots \ldots \ldots$ & 3,800 \\
\hline HFC-152a $\ldots \ldots \ldots \ldots \ldots$ & 140 \\
\hline HFC-227ea $\ldots \ldots \ldots \ldots \ldots$ & 2,900 \\
\hline HFC-236fa $\ldots \ldots \ldots \ldots \ldots$ & 6,300 \\
\hline HFC-245ca $\ldots \ldots \ldots \ldots \ldots$ & 560 \\
\hline Chloroform ............ & 4 \\
\hline Methylene Chloride ........ & 9 \\
\hline Perfluoromethane ... & 6,500 \\
\hline Perfluoroethane & 9,200 \\
\hline Perfluoropropane $\ldots \ldots \ldots \ldots$ & 7,000 \\
\hline Perfluorobutane & 7,000 \\
\hline Perfluoropentane ... & 7,500 \\
\hline Perfluorohexane $\ldots \ldots \ldots \ldots$ & 7,400 \\
\hline Perfluorocyclobutane . . . . . . . & 8,700 \\
\hline Trifluoroiodomethane & $<1$ \\
\hline Sulfur Hexafluoride $\ldots \ldots \ldots \ldots$ & 23,900 \\
\hline
\end{tabular}


coal mining and natural gas production and delivery. The CONSOL Coal Group, one of the top 10 producers and distributors of coal in the United States, reported methane emissions reductions in excess of 500,000 metric tons in 1995 (equivalent to 12 million metric tons of carbon dioxide) through methane recovery from mine operations and closure of coal mines with high methane emissions.

As shown in Table 4, projects with the principal objective of reducing methane emissions also had substantial carbon dioxide reduction benefits. Such benefits may accrue when captured methane displaces oil or coal as an energy source, or when reduced landfilling results in the release of less carbon dioxide from aerobic decomposition (in the presence of oxygen). Projects that reduced emissions of perfluorocarbons and sulfur hexafluoride also generated large reductions on a carbon dioxide equivalent basis. Overall, the less than 10 percent of projects that focused on controlling emissions other than carbon dioxide were responsible for nearly 40 percent of the total carbon dioxide equivalent reductions reported. This total excludes chlorofluorocarbons (CFCs) and hydrochlorofluorocarbons (HCFCs), despite the large reductions reported for them on a full molecular weight basis, because of the uncertainty associated with their net warming potential. ${ }^{4}$

\section{Emissions Mitigation Reporting in the Context of National Emissions Trends}

Emissions mitigation projects reported for 1995 indicate aggregate reductions in the range of $\mathbf{1 8 0}$ million metric tons carbon dioxide equivalent. How could such large reductions be achieved by reports from a relatively limited number of respondents? Equally important, how can one reconcile such a total to national emissions levels that are rising at an annual rate of 50 to 100 million metric tons carbon dioxide equivalent?

In fact, the voluntary reporting database cannot be reconciled to the database for the national emissions inventory. They reflect two different accounting frameworks. For the most part, the national inventory calculates emissions from energy used to produce a wide variety of goods and services. Year-to-year comparisons are based on historical performance, mainly associated with trends in energy production and consumption.

Emissions mitigation data are not necessarily related to historical experience. Only a handful of reporters indicate mitigation achievements in comparison with historical performance baselines. The vast majority of

Table 4. Summary of Project-Level Emissions Reductions and Carbon Sequestration by Reduction Objective, Data Year 1995

(Metric Tons Carbon Dioxide Equivalent)

\begin{tabular}{|c|c|c|c|c|c|}
\hline \multirow[b]{2}{*}{ Gas } & \multicolumn{4}{|c|}{ Reductions by Project Objective } & \multirow[b]{2}{*}{$\begin{array}{c}\text { Total } \\
\text { Reductions }\end{array}$} \\
\hline & \begin{tabular}{c|} 
Reduce \\
Carbon Dioxide \\
Emissions
\end{tabular} & $\begin{array}{c}\text { Reduce } \\
\text { Methane and } \\
\text { Nitrous Oxide } \\
\text { Emissions }\end{array}$ & $\begin{array}{c}\text { Increase } \\
\text { Carbon } \\
\text { Sequestration }\end{array}$ & $\begin{array}{l}\text { Reduce } \\
\text { Emissions of } \\
\text { Halogenated } \\
\text { Substances }\end{array}$ & \\
\hline Carbon Dioxide & $115,039,852$ & $33,267,241$ & $7,037,746$ & 0 & $155,344,840$ \\
\hline Methane ...... & 249,010 & $23,613,180$ & 0 & 0 & $23,862,190$ \\
\hline Nitrous Oxide & $1,253,526$ & 1,181 & 0 & 0 & $1,254,707$ \\
\hline PFCs ...... & 0 & 0 & 0 & $3,192,463$ & $3,192,463$ \\
\hline Other Gases & 0 & 0 & 0 & 208,481 & 208,481 \\
\hline Total & $116,542,389$ & $56,881,602$ & $7,037,746$ & $3,400,944$ & $183,862,681$ \\
\hline CFCs, HCFCs & 0 & 0 & 0 & $20,304,696$ & $20,304,696$ \\
\hline
\end{tabular}

Notes: Totals include all emissions reductions reported. No attempt has been made to correct for double counting, where more than one entity has (or may have) reported on the same emissions reduction project. CFCs and HCFCs are not included in the totals because of the uncertainty associated with estimates of net global warming potential for these gases. Their direct warming effects (radiative forcing) are offset by indirect cooling effects (destruction of stratospheric ozone, another greenhouse gas). For the same reason, methyl chloroform has been excluded from the "Other Gases" category.

Source: Energy Information Administration, Forms EIA-1605 and EIA-1605EZ, "Voluntary Reporting of Greenhouse Gases."

\footnotetext{
${ }^{4}$ For a discussion of global warming potentials, see Intergovernmental Panel on Climate Change, Climate Change 1995: The Science of Climate Change (Cambridge, UK: Cambridge University Press, 1996).
} 
reporters report emissions mitigation accomplishments relative to a hypothetical baseline-what emissions would have been had the mitigation effort not been undertaken. Reporters can participate in establishing mitigation records even for projects that involve new activities for which no historical records exist and which, in fact, lead to overall increases in emissions levels. In this context, success of the mitigation effort relates to moderating the growth rate of emissions. Similarly, an entity whose scope of activity is not increasing, but whose customer base is growing, may report mitigation actions that only slow a rise in emissions. Thus, it is possible to observe both increases in specific emissions mitigation successes and rising levels of national emissions (see box in Chapter 3, page 28).

Several other factors complicate the interpretation of data on emissions mitigation efforts. Many actions have both direct and indirect effects on emissions. The scope of project accounting may ignore indirect increases associated with a project's implementation. Thus, the shutdown of a coal-fired power plant could save direct emissions for a reporter which, in some measure, might be offset if replacement power were supplied by a nonreporting emitter. Even if a project is unambiguous in its effect, the responsibility for its implementation may not be. Is the entity capturing methane from a landfill the mitigating agent, or is it the utility that promises to purchase the methane as fuel (thereby justifying investment in recovery equipment)? Multiple sponsorship of individual projects can lead to double reporting of emissions savings when pro rata contributions to project implementation cannot be readily identified and adjusted.

Still another consideration affecting interpretation of reduction reports relates to the selection bias inherent in voluntary reporting. Reporters participate to share data on successes. Many nonreporters may have successes to report as well. Even more important, however, is the fact that nonreporters will include actors who have no reductions to report or who are engaged primarily in activities that generate increasing levels of greenhouse gas emissions.

How then does the voluntary reporting of emissions mitigation efforts help to address the national problem of rising levels of greenhouse gas emissions? The estab- lishment of an accounting framework for enterprises to assess emissions sources and options for reduction helps provide a new metric for decisionmakers reviewing the consequences of actions taken. Heightened awareness can set the stage for emissions avoidance or mitigation. Additionally, the program can help promote activism and innovation in the search for emissions reduction strategies in at least three ways:

- Replicating of small projects on a large scale. Many projects achieve modest emissions reduction benefits individually, but are widely applicable. One major utility described how videoconferencing reduced employee travel between its various locations for meetings. While the reduction in emissions resulting from the decrease in vehicle miles traveled was not extraordinary, multiplying this reduction by even a fraction of the numbers of companies across the United States that are similarly geographically dispersed could produce a substantial aggregate benefit. By sharing information on projects such as this, voluntary reporting can promote replication of cost-effective emissions mitigation measures.

- Enhancing project scale through pooling of resources. Organizational initiatives in which several participants pool resources can enhance the scale of the projects undertaken. For example, 40 different electric utilities are jointly sponsoring a forestry project in Belize that will enhance carbon sequestration through improved forest management techniques on 120,000 acres. Voluntary reporting promotes such collaborations by providing recognition to the participating companies.

- Identifying reduction opportunities. Through the accounting of emissions performance records necessary for voluntary reporting, reporters gain an understanding of the greenhouse gas emissions consequences of their activities, which enables them to identify the most cost-effective reduction opportunities. The realization that the global warming potential of sulfur hexafluoride is nearly 24,000 times that of carbon dioxide spurred at least one reporter to halve its emissions of this gas.

If the Voluntary Reporting of Greenhouse Gases Program assists in any of these dimensions, some progress toward national stabilization targets may be made. 


\section{Reducing Emissions from Electricity Supply}

The electric utility sector produces more than 1.81 billion metric tons of carbon dioxide per year-about one-third of total U.S. carbon dioxide emissions. These emissions result from the combustion of fossil fuelscoal, oil, and natural gas-during the electricity generation process. Coal is the largest contributor to utility emissions, accounting for 88 percent of the total, reflecting the fact that coal is the primary energy source used for electricity generation (51 percent of total U.S. generation), as well as having the highest emissions per unit of energy used. When it is burned, coal emits about 70 percent more carbon dioxide per British thermal unit (Btu) of energy produced than does natural gas.

Between 1990 and 1995, carbon dioxide emissions from the utility sector ${ }^{5}$ increased by 62 million metric tons, or 3.5 percent. This trend reflects U.S. economic growth and corresponding increases in energy consumption. However, electric utility carbon dioxide emissions grew at a slower rate than total energy consumption, which grew by 7.3 percent between 1990 and 1995, which, in turn, is slower than the growth of the U.S. economy (10.5 percent). Factors that helped to slow the growth in emissions include increased reliance on natural-gasfired and nuclear power plants and efficiency improvements in both the generation and use of electricity. Between 1994 and 1995, electric utility emissions declined despite a 2.9-percent increase in electricity consumption, because nuclear and hydroelectric power plants increased their share of total generation at the expense of fossil-fuel-fired plants. ${ }^{6}$

\section{Overview of Projects Reported}

Projects undertaken by the electric utility industry usually reduce emissions in one of two ways. First, they may displace higher emitting fossil fuels (e.g., coal) with lower emitting fuels (e.g., natural gas) or non-emitting energy sources (hydropower, geothermal, solar, wind, and nuclear). Alternatively, by improving the efficiency of electricity generation, transmission, and distribution, they may reduce the quantity of fossil fuel used by power plants. This chapter considers these two groups of projects separately, following a brief overview of the reported electricity supply projects.

Electricity supply projects are the most numerous reported to the Voluntary Reporting Program, accounting for 31 percent of all projects reported in 1996. Eighty-six organizations, including one trade association, one independent power producer, and 84 electric utilities, reported a total of 303 electricity supply projects, a 31-percent increase from the previous reporting year. Forty-four new projects were undertaken in 1995-a slight decline from 1994, when 49 new projects were begun.

Electricity supply projects are also the largest projects reported. More than one-half of all electricity supply projects reported in 1996 achieved carbon dioxide reductions in excess of 10,000 metric tons each. Of the 21 largest projects reported (yielding a total of more than 1 million metric tons of carbon dioxide reductions in 1995), 15 were electricity supply projects (Figure 2).

\section{Figure 2. Electricity Emissions Reduction Projects by Project Size}

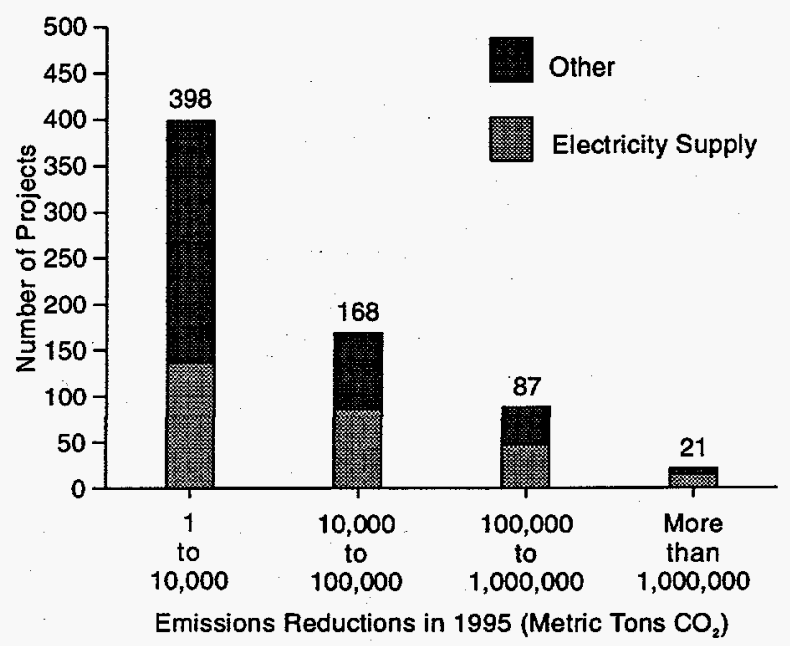

Source: Energy Information Administration, Forms EIA-1605 and EIA-1605EZ, "Voluntary Reporting of Greenhouse Gases."

\footnotetext{
${ }^{5}$ Including independent power producers but excluding cogeneration facilities.

${ }^{6}$ Energy Information Administration, Emissions of Greenhouse Gases in the United States 1996, DOE/EIA-0573(96) (Washington, DC, October 1997), pp. 11-19.
} 


\section{Reducing the Carbon Content of Energy Sources}

Fuel-switching projects, power plant availability improvements, and increases in low-emitting capacity typically reduce the carbon content of the fuel or energy sources used in electricity generation. A total of 104 such projects were reported for 1995 (Figure 3), including some of the largest projects reported to the Voluntary Reporting Program. It should be noted that some carbon content reduction projects are in fact "hybrids," combining efficiency improvements with measures such as availability improvements or increases in low-emitting capacity.

\section{Figure 3. Carbon Content Reduction Projects} by Project Type

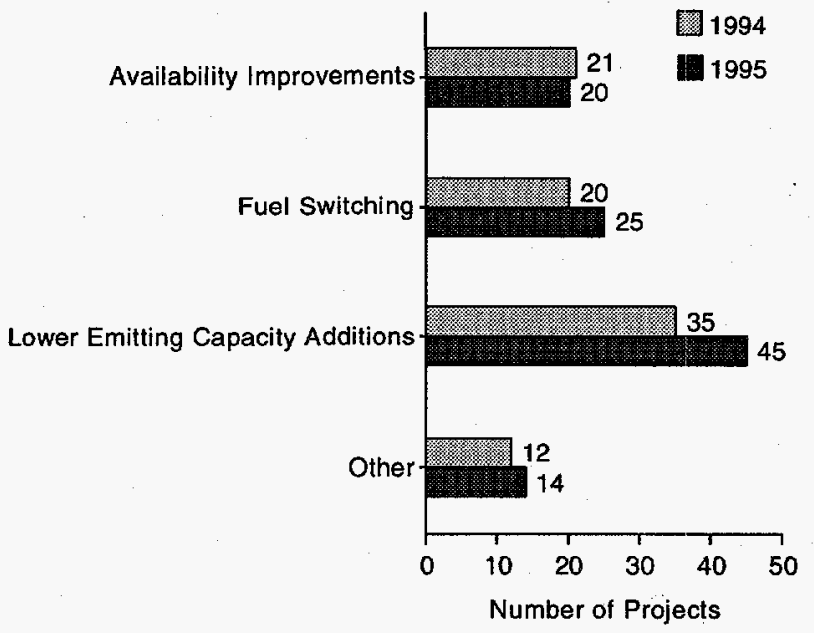

Notes: Excludes electricity supply projects reported on Form ElA1605EZ. Some projects may be counted in more than one category. Source: Energy Information Administration, Form EIA-1605, "Voluntary Reporting of Greenhouse Gases."

\section{Availability Improvements}

By increasing the generation from lower emitting power plants, availability improvement projects provide a commensurate reduction in the amount of generation supplied by higher emitting plants. The number of availability improvement projects reported for 1995 held fairly steady at 20, down one from the 21 reported for 1994 (Figure 3). ${ }^{7}$ As was the case last year, availability improvement projects were among the most effective in terms of the magnitude of their impact on carbon dioxide emissions. On average, availability improvements reduced carbon dioxide emissions by more than 2.2 million metric tons per project in 1995.

Availability improvement projects primarily reflect developments within the nuclear power industry. Of the 20 availability improvement projects reported, 11 occurred at nuclear power plants. Mainly through significant advances in operating, maintenance, and refueling procedures, capacity factors at nuclear plants were increased, displacing fossil-based power generation. Because nuclear power plants are invariably large baseload facilities, even a fairly small improvement in plant availability can lead to a major reduction in fossil fuel consumption. In some cases, the capacity factor improvements were anything but small; for example, Niagara Mohawk Power Corporation raised the capacity factor at its Nine Mile Point nuclear plant from about 30 percent during the 1987 to 1990 time period, to over 70 percent during the 1991 to 1995 period.

Examples of specific actions taken to improve nuclear plant capacity factors include:

- Carolina Power \& Light Company's adoption of techniques for on-line maintenance to avoid maintenance outages, and its adoption of industry best practices to reduce the duration of refueling outages.

- A move to a 2-year refueling cycle and enhancement of the Preventive Maintenance and Surveillance programs at General Public Utilities Corporation's Oyster Creek and Three Mile Island nuclear plants.

- The extension of refueling schedules and reduction of refueling outage durations at Texas Utilities Electric Company's Comanche Peak nuclear power plant.

\footnotetext{
${ }^{7}$ Most of the 21 projects reported for 1994 were included in the 20 projects reported for 1995 , because they continued to yield emissions reductions in 1995 . This is typically true not only of availability improvement projects but of all reported projects. Most projects continue to yield emissions reductions over an extended period of time; for example, many of the availability improvement projects at nuclear power plants involved the adoption of new maintenance and refueling programs that, once in place, are followed over a multi-year period. Reporters continue to report the annual emissions reductions achieved by these long-lived projects on a yearly basis. Note, however, that some projects reported for 1994 were not reported for 1995 (e.g., because the projects were discontinued, or reporters chose not to report them). Also, in a few cases, projects may have been reclassified as to their project type between 1994 and 1995. For these reasons, the number of reported projects in some cases declined between 1994 and 1995 (availability improvement projects are an example). For the vast majority of project types, however, the number of reported projects increased, as 1994 projects continued and new projects were reported for the first time.

${ }^{8}$ Estimates of average reductions across reporters should be viewed with caution, since reporters may not calculate reductions in the same way, and multiple reporters may report on some of the same activities (see Appendix B). Averages are presented only to provide a rough indication of the relative sizes of different types of projects.
} 


\section{Carbon Content Reduction Projects: Definitions and Terminology}

The purpose of the electricity generation process is to convert other forms of energy (e.g., heat) into electrical energy. During this process, the combustion of fossil fuels to produce heat causes greenhouse gas emissions. In addition to substantial releases of carbon dioxide, fossil fuel combustion also results in the emission of small quantities of methane and nitrous oxide. Carbon content reduction projects typically reduce greenhouse gas emissions by replacing higher emitting fuels (such as coal) with cleaner burning fuels (such as natural gas) or non-emitting energy sources (such as nuclear power).

Availability Improvements. By reducing the frequency and length of planned and unplanned power plant outages, availability improvement projects can result in increased use of the affected plant. This is particularly true if the plant is a baseload plant (i.e., a plant that is generally used on an around-the-clock basis except during plant outages), but it may hold true for other types of plants as well. If the resulting increased generation from the affected plant displaces generation that otherwise would have been produced by a higher emitting plant, emissions reductions will result. Power plant utilization is measured by the plant's capacity factor, defined as the ratio of the average load on the plant over a given period to its total capacity. For example, if a 100-megawatt plant operates (on average) at 75 percent of capacity (i.e., at a load of 75 megawatts) over a period of a year, the plant's capacity factor is 75 percent.

Fuel Switching. The amount of carbon contained in fossil fuels and released in the form of carbon dioxide during combustion varies, depending on the type of fuel. Thus, carbon dioxide emissions from a power plant can be reduced by switching from a higher emitting fuel (such as coal) to a lower emitting fuel (such as natural gas).

Increases in Lower Emitting Capacity. By increasing the capacity of an existing lower emitting or nonemitting plant (e.g., a hydroelectric plant), or by constructing new generating capacity (e.g., wind turbines), a utility can reduce or avoid reliance on higher emitting plants. The result will be a reduction in greenhouse gas emissions from the displaced plants.

\section{Fuel Switching}

Twenty-five fuel-switching projects were reported, ${ }^{9}$ compared with 20 in the previous reporting year. Seventeen of the projects involved switching from coal to other fuel types (Figure 4). Fuels used in place of (or co-fired with) coal included natural gas, waste oil from transformers, wood waste, and tire-derived fuel. Since coal is the highest emitting fossil fuel, switching from. coal to other fuels can have a substantial effect on carbon dioxide emissions. For example, switching from bituminous coal to natural gas will reduce carbon dioxide emissions per unit of energy consumed by approximately 43 percent. While other reported actions-namely, switching from oil to gas-may not lead to reductions of the same magnitude, they too can affect emissions. Typically, carbon dioxide emissions reductions on the order of 200,000 metric tons per year were achieved as a result of the reported fuel-switching projects.

The 25 reported fuel switching projects include a number of new projects that were started in 1995:

- American Electric Power added natural gas firing capability at its coal-fired Conesville Units 1-3. In 1995, natural gas accounted for approximately 7 percent of the generation produced by the units and 7 percent of the heat input to the units. The use of natural gas offset approximately 38,000 metric tons of coal.

\section{Figure 4. Fuel-Switching Projects by Project Type}

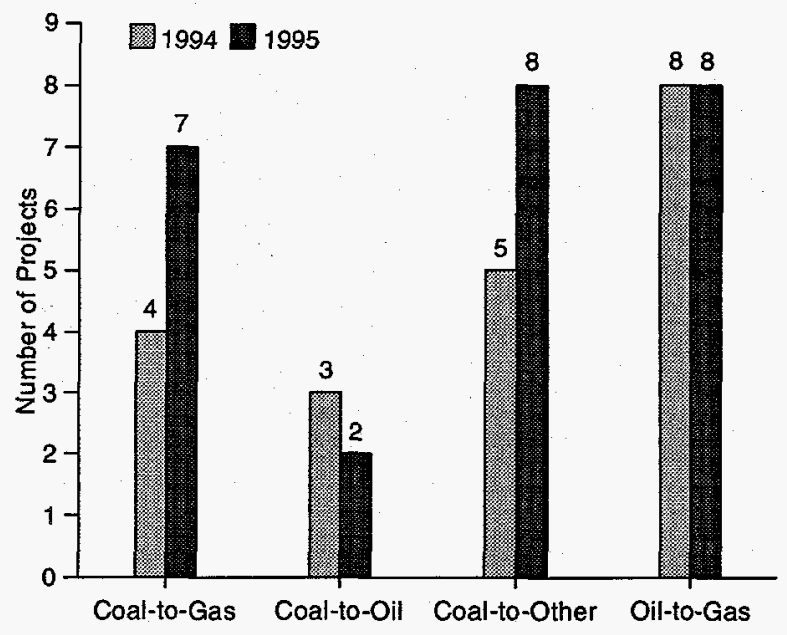

Notes: Excludes electricity supply projects reported on Form EIA1605EZ.

Source: Energy Information Administration, Form EIA-1605, "Voluntary Reporting of Greenhouse Gases."

${ }^{9}$ Some of these projects were "hybrids," combining fuel switching with other project types. 
- General Public Utilities Corporation initiated a demonstration project in conjunction with the Electric Power Research Institute, involving co-firing wood resources with coal at its Shawville generating station. Three types of wood fuel were tested: sawdust, right-of-way tree trimmings, and hybrid poplar. The Pennsylvania Energy Office provided assistance on the project.

- Illinois Power Company converted its Vermilion Units 1 and 2 from coal to natural gas in June 1995, resulting in estimated carbon dioxide emissions reductions of more than 49,000 metric tons.

- Mississippi Power Company, an operating unit of The Southern Company, spent approximately $\$ 2$ million on burners, piping and controls to make Units 4 and 5 at the Plant Jack Watson capable of burning natural gas as well as coal. In 1995, this project offset nearly 1.8 trillion Btu of coal and reduced carbon dioxide emissions by an estimated 66,942 metric tons. The plant will continue to burn gas as a substitute for coal whenever the economics and fuel availability are favorable.

\section{Increases in Lower Emitting Capacity}

Projects involving the construction of new, lower emitting power plants or increases in the capacity of existing lower emitting plants were among the most numerous electricity supply projects reported. A total of 45 such projects were reported; ${ }^{10}$ up from 35 in the last reporting year. The majority involved the installation of new nuclear, renewables, and hydropower capacity, with essentially no greenhouse gas emissions (Figure 5); 6 projects involved additional natural-gasfired capacity, up from 3 projects reported last year.

In general, most of these projects were either small additions to existing power plants or the opening of small new plants (primarily renewables plants). The emissions reductions achieved therefore tended to be small in comparison with those for availability improvement projects. One major exception was the return of the Tennessee Valley Authority's (TVA) Browns Ferry Nuclear Units 2 and 3 to service. These units had been shut down in 1985. After extensive modifications, Unit 2 was restarted in 1991 and Unit 3 in December 1995. The return of the units to operation reduced TVA's need to rely on coal-fired generation. TVA estimated the project's total carbon dioxide emissions reductions (due to the operation of both units) at nearly 9.3 million metric tons in 1995, making this one of the largest projects reported on Form EIA-1605. Furthermore, TVA expected the Watts Bar Nuclear Plant Unit
Figure 5. Capacity Addition Projects by Energy Source

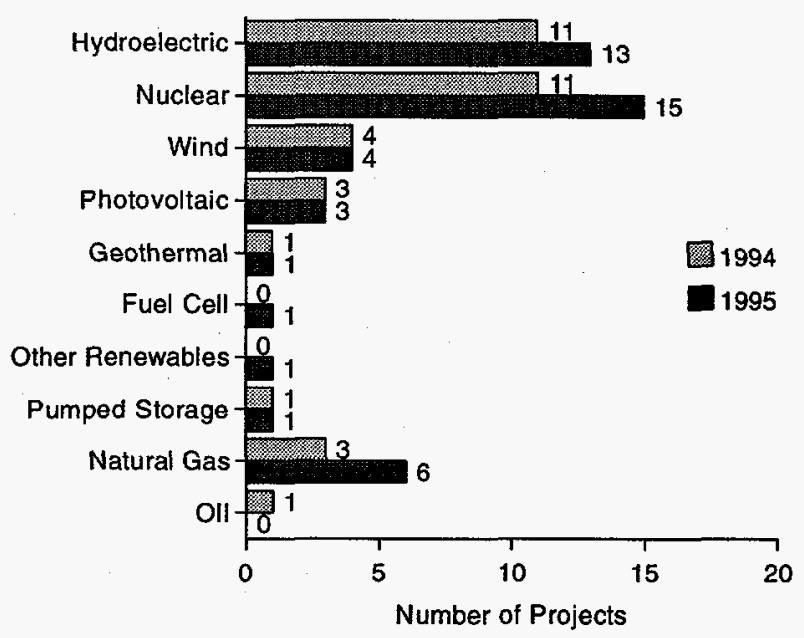

Note: Excludes electricity supply projects reported on Form ElA1605EZ.

Source: Energy Information Administration, Form ElA-1605, "Voluntary Reporting of Greenhouse Gases."

1 to begin operation in 1996. With the addition of Watts Bar, and the realization of the full impact of Browns Ferry Unit 2 (which operated for only one month in 1995), TVA projects that emissions reductions will rise to over 16 million metric tons per year. To put this in perspective, 16 million metric tons corresponds to 0.9 percent of total U.S. carbon dioxide emissions from the electricity sector.

One of the new capacity addition projects reported this year was a fuel cell research project undertaken by Duquesne Light Company, one of 36 new reporters. The project, begun in July 1993, installed and operated a 200-kilowatt natural gas fuel cell at Pittsburgh International Airport. The fuel cell is used in baseload mode and meets the needs of approximately 3 percent of the total load on its circuit. Waste heat from the fuel cell is recovered and used to provide space heating.

Other new projects that became operational in 1995 include New England Electric System (NEES) Companies' repowering of the Manchester Street Station and Niagara Mohawk Power Corporation's capacity upgrade at the Nine Mile Point Unit 2 nuclear plant. The new NEES project converted Manchester Street from a small, relatively inefficient oil-fired plant to a midsized, efficient combined-cycle plant utilizing natural gas. Estimated emissions reductions resulting from the project were over 236,000 metric tons in 1995 . Niagara Mohawk's project, which increased the capacity of Nine

\footnotetext{
${ }^{10}$ Some of these projects were "hybrids," combining capacity additions with other project types.
} 


\section{Project Profile: Waverly Light \& Power Company's Wind Turbine Project}

Renewable electricity generation projects, such as geothermal energy, photovoltaics, and wind power, produce essentially no greenhouse gas emissions, while at the same time reducing reliance on fossilfuel-fired generating stations. A number of electric utilities have been experimenting with these relatively new generation technologies, including Waverly Light \& Power Company (WLP), a small municipal utility serving the town of Waverly, Iowa. In 1993, WLP installed an 80-kilowatt wind turbine as an experimental demonstration project. On Form EIA-1605, WLP describes the wind turbine project as follows:

\begin{abstract}
Waverly Light \& Power contracted with $R$. Lynette and Associates in 1991 to perform a preliminary study to investigate the potential for wind energy in the Waverly, Iowa area. The results of that study indicated that wind energy may be feasible in the area, but that a more thorough investigation, using actual site wind speed data, was necessary to confirm this.
\end{abstract}

In September, 1991, WLP applied for, and was awarded, a Demonstration of Energy-Efficient Developments (DEED) Program grant from the American Public Power Association (APPA) to further study the potential for wind energy applications in the Waverly, Iowa area. The WLP Board of Directors authorized Phase I of the study, which was limited to the following tasks:

(1). Determining performance issues;

(2). Resolving utility and government issues; and

(3). Developing a financial model for estimating the cost of energy.

The goals of this project were to gain experience and knowledge in operating and maintaining wind generating systems, to document the costs and performance of wind turbines with advanced components in Midwest wind regimes, to demonstrate the ability of a small utility to incorporate wind energy into their generation mix, and to acquire knowledge that can be used to develop larger scale projects in the future. All of these goals were fully achieved during this project....

The wind turbine project displaced power that would have been generated by a coal-fired power plant. WLP estimated the resulting annual carbon dioxide emissions reduction at 37 metric tons in 1992, rising to 113 metric tons in 1995. Based on the success of the initial 80-kilowatt wind turbine, WLP is pursuing plans to install approximately 1 megawatt of wind capacity.
Mile Point Unit 2 by 116 megawatts, yielded carbon dioxide emissions reductions of just over 100,000 metric tons.

\section{Other Carbon Content Reduction Projects}

Fourteen other projects were reported (up from 12 for 1994), including 6 projects involving decreases in higher emitting capacity and 6 involving changes in the dispatching of power plants. The demand for electricity is not constant but fluctuates according to such factors as the time of day and the season. Individual power plants are brought on line or taken off line as demand fluctuates. The order in which power plants are used or dispatched is generally determined by economics; i.e., the plants that can be operated at the lowest cost are dispatched first, while the highest cost plants are last in the dispatch order. Changes in the dispatch order can affect carbon dioxide emissions; emissions will be reduced when lower emitting plants are moved up in the dispatch order and used more frequently.

As an example, Southern California Edison (SCE) reported three projects involving their purchase of electricity from independent power producers (IPPs).
Because the IPPs generated the power using new (post1990) renewables facilities (specifically, biomass, geothermal, and wind facilities), the power purchases effectively represented a change in Southern California Edison's dispatch order; specifically, the renewable energy displaced SCE's marginal natural-gas-fired generating stations. It should be noted that the IPPs that generated the power were classified as "qualifying facilities" under the Public Utility Regulatory Policies Act of 1978 (PURPA). Under PURPA, electric utilities are required to purchase power from such qualifying facilities. SCE estimated that, in 1995, carbon dioxide emissions were reduced by a total of over 500,000 metric tons as a result of the three dispatching projects.

General Public Utilities (GPU) Corporation's Form EIA1605 provides examples of projects involving decreases in higher emitting capacity. GPU reported the retirement of generating units at the Sayerville, Front Street, and Williamsburg power plants as three separate projects. The Front Street and Williamsburg units were coal-fired, while the Sayerville units burned natural gas and oil. The total emissions reductions resulting from these three projects were estimated at 628,000 metric tons of carbon dioxide in 1995. 


\section{Increasing Efficiency in Electricity Production and Distribution}

Reported projects that improve the efficiency of electricity generation, transmission, and distribution were both more numerous and smaller than carbon content reduction projects. Efficiency improvement tends to be an ongoing effort at electric utilities, yielding a continuous stream of small, incremental improvements rather than one-time dramatic increases in efficiency. For example, heat rate improvement projects are often undertaken in response to normal plant deterioration. As power plants age, efficiency tends to erode gradually. Utilities seek to maintain heat rates by replacing old, worn-out equipment. Similarly, new energy-efficient transformers are often installed gradually over a period of years, as old transformers fail.

Although the impact of any one efficiency project on carbon dioxide emissions may be relatively small, their combined potential is significant. Consider, for example, electricity transmission and distribution. Among U.S. utilities, energy losses associated with transmission and distribution typically fall in the 5 to 10 percent range, with an average of about 7 percent. The generation of this lost energy causes carbon dioxide emissions of about 127 million metric tons. Hence, a one percentage point reduction in transmission losses for the United States as a whole would yield an annual reduction in emissions of 18 million metric tons. This is a sizable quantity (although, in perspective, it is only about 2 million metric tons larger than the annual emissions reductions TVA expects to achieve from the opening of the Browns Ferry and Watts Bar nuclear plants).

A total of 185 efficiency improvement projects were reported for 1995, including some "hybrid" projects that combined efficiency improvements with measures such as availability improvements. Efficiency improvement projects fall into two main categories: (1) generation, involving efficiency improvements in the conversion of fossil fuels and other energy sources into electricity; and (2) transmission and distribution, involving improvements in the delivery of electricity from the power plant to the end user. For 1995, 107 generation projects and 78 transmission and distribution projects were reported (Figure 6).

\section{Generation Projects}

Efficiency Improvements. Improvements in generating efficiency are the most numerous type of efficiency project reported (Figure 6). A total of 97 such projects were undertaken, up 24 percent from the number reported last year. ${ }^{11}$ Heat rate improvements at coalfired power plants are a particularly popular means of increasing efficiency and reducing emissions. The average carbon dioxide emissions reduction per project was roughly 60,000 metric tons per year, making these projects somewhat larger than transmission and distribution projects but significantly smaller (less than half the size) of the reported cogeneration projects. ${ }^{12}$ There are numerous opportunities for improving efficiency at existing power plants, but the efficiency gains-and hence reductions in fuel consumption and emissionsare limited by technology and tend to be small. Even in the context of long-established technologies (e.g., coalfired steam turbine plants) efficiency gains were reported in a wide range of projects. Reported heat rate improvements typically were between 0.5 and 2.5 percent.

\section{Figure 6. Efficiency Improvement Projects by Project Type}

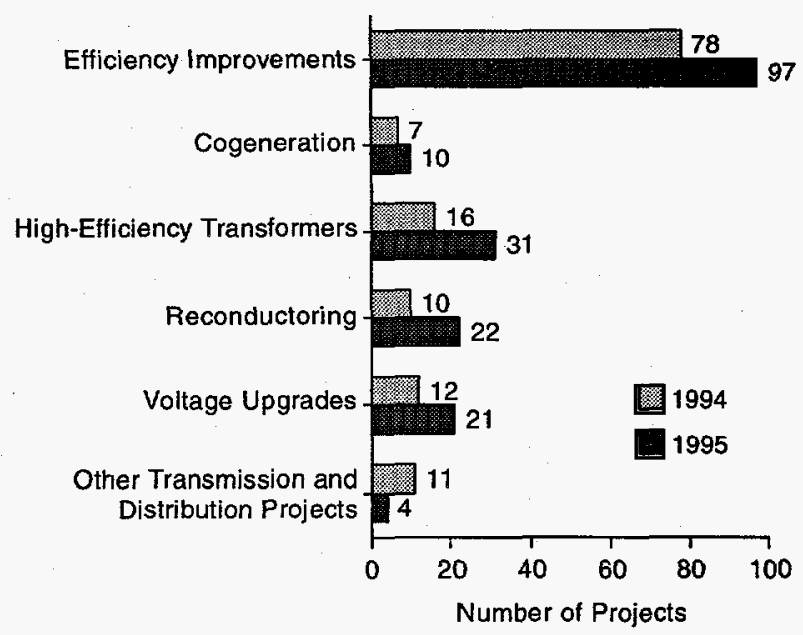

Notes: Excludes electricity supply projects reported on Form EIA$1605 E Z$. Some projects may be counted in more than one category. Source: Energy information Administration, Form EIA-1605, "Voluntary Reporting of Greenhouse Gases."

New projects undertaken in 1995 provide some examples of the types of improvements made and the magnitude of the resulting efficiency gains:

- Allegheny Power Service Corporation replaced the boiler pressure components, burners, and air preheating devices at its Armstrong Unit 1. Initial performance data indicate that a 2-percent improvement in boiler efficiency was achieved. Reported carbon dioxide emissions reductions for the project were 3,079 metric tons.

\footnotetext{
${ }^{11}$ Some of these projects were "hybrids," combining efficiency improvements with other project types.

${ }^{12}$ Estimates of average reductions across reporters should be viewed with caution, since reporters may not calculate reductions in the same way, and multiple reporters may report on some of the same activities (see Appendix B). Averages are presented only to provide a rough indication of the relative sizes of different types of projects.
} 


\section{Efficiency Projects: Definitions and Terminology}

\section{Generation Projects}

It is neither theoretically nor practically possible to convert all of the thermal or other energy produced by a power plant into electrical energy. In fact, most of the energy is lost rather than converted. Typically, U.S. steam-electric generating plants operate at efficiencies of about 33 percent, meaning that two-thirds of the thermal energy produced is lost. Some more advanced power plants have higher efficiencies, but even combined-cycle plants (in which the waste heat from a gas turbine is recovered to produce steam to drive a steam turbine) typically have efficiencies of only 45 percent. Generator projects seek to improve power plant efficiencies either by reducing the amount of energy lost during the conversion process or by recovering the lost energy for subsequent application.

Efficiency Improvements. By increasing the efficiency of the generation process, efficiency improvement projects at fossil-fuel-fired power plants reduce the plants' heat rate, defined as the amount of fossil energy (measured in Btu) needed to produce each kilowatthour of electricity. The result is a reduction in the amount of fuel that must be burned to meet generation requirements, and hence a reduction in carbon dioxide (and other greenhouse gas) emissions. Efficiency improvements at nonfossil power plants (e.g., hydroelectric plants) can also reduce greenhouse gas emissions. Emissions reductions occur if the efficiency improvement leads to an increase in the amount of electricity generated by the affected plant, with a consequent reduction in the amount of electricity that must be generated by other (fossil fuel) plants to meet demand.

Cogeneration. Only a portion of the heat generated during the combustion of fossil fuels can be converted into electrical energy; the remainder is generally lost. Cogeneration involves the recovery of this thermal energy, for use in subsequent applications. Cogeneration facilities typically employ either topping or bottoming cycles. In a topping cycle, thermal energy is first used to produce electricity and then recovered for subsequent applications. Topping cycles are widely used in industry as well as utility power plants that sell electricity and steam to customers. In bottoming cycles, the thermal energy is first used to provide process heat, from which waste heat is subsequently recovered to generate electricity. Bottoming cycle applications are less common and are usually associated with high-temperature industrial processes. Because cogeneration involves the recovery and use of thermal energy that would otherwise be wasted, it reduces the amount of fossil fuel that must be burned to meet electrical and thermal energy requirements, hence reducing greenhouse gas emissions.

\section{Transmission and Distribution Projects}

The purpose of the electricity transmission and distribution system is to deliver electrical energy from the power plant to the end user. Due to resistance to the flow of the electrical current in the cables, transformers, and other components comprising the transmission and distribution system, a portion of the energy (typically about 7 percent) is lost in the form of heat. Improving the efficiency of the various system components can reduce such "line losses," reducing the amount of generation required to meet end-use demand and, thus, power plant fossil fuel consumption and greenhouse gas emissions.

High-Efficiency Transformers. Transformers, used to change the voltage between different segments of the transmission and distribution system, are a major source of system losses. Transformer losses occur as a result of impedance to the flow of current in the transformer windings, and because of hysteresis and eddy currents in the steel core of the transformer. When existing transformers are replaced with highefficiency transformers (including improved silicon steel transformers and amorphous core transformers) transformer losses are reduced.

Reconductoring. Like transformers, conductors (including feeders and transmission lines) are a major source of transmission and distribution system losses. In general, the smaller the diameter of the conductor, the greater its resistance to the flow of electric current, and the greater the consequent line losses. Reconductoring involves the replacement of existing conductors with larger diameter conductors.

Distribution Voltage Upgrades. Line losses are dependent, in part, on the voltage at which the various segments of the transmission and distribution system operate. By upgrading the voltage of any segment, line losses can be reduced. 


\section{Reporter Profile: The Southern Company}

The Southern Company is a large investor-owned utility, whose operating subsidiaries include Georgia Power, Alabama Power, and Mississippi Power, among others. For 1995 The Southern Company reported on projects that cover the full gamut of efficiency improvement measures, from voltage upgrades and transformer replacements to cogeneration and heat rate improvements at all 22 of the utility's coal-fired power plants. The Southern Company describes its various efficiency improvement projects as follows:

\begin{abstract}
Heat Rate Improvement on Coal-Fired Capacity. From 1990 to 1994, coal-fired generating plants in The Southern Company improved their average net heat rate from $9,810 \mathrm{Btu}$ per kilowatthour to 9,739 Btu per kilowatthour. Upgrades and better operation and maintenance of plant equipment were key to the heat rate improvement effort. Examples of the types of projects undertaken during this time include enhanced boiler heat recovery in economizer and air preheater systems, component replacement for efficiency gain (fans, heat exchangers, pumps), heat rejection upgrades, improved turbine performance monitoring/maintenance, etc. This focus on efficiency has significantly lowered the amount of coal used to provide each unit of energy from the plants.
\end{abstract}

This project includes all 22 of the Southern Company's coal-fired power plants.

Chevron Cogenerating Plant, Unit 5. The Southern Company subsidiary, Mississippi Power Company, upgraded the cogeneration facility at the Cheoron refinery in Pascagoula, Mississippi to include a new 75-megawatt unit in 1994. Although the facility has been in service for 28 years, this fifth unit, which essentially doubled the plant capacity, began commercial operation on May 14, 1994. This natural gas-fired facility produces electricity and process steam for a significant industrial customer and provides The Southern

- Entergy Services, Incorporated replaced the highpressure feedwater heater at its Independence unit, resulting in a 2-percent heat rate improvement and carbon dioxide emissions reductions of 65,693 metric tons.

- Union Electric Company upgraded the control system at its Sioux Plant. Before the project, many of the plant's critical controls frequently had to be operated on a "manual" basis. The project has en-
Company system with less $\mathrm{CO} 2$ emissions as compared to coal-fired baseload capacity.

The $\mathrm{CO} 2$ reductions are the result of the following: (1) Without the addition of this unit, Mississippi Power would have continued to serve Chevron's baseload electrical need with coal-fired generation ....

(2) Without the addition of this unit, Cheoron would have met its steam needs less efficiently with its own natural gas-fired boilers....

Bulk Power Transmission Improvements. In 1991, about 7.4 percent of U.S. electric energy was lost between generation facilities and end use. In the Southern Company system, the losses associated with the bulk transmission system in general are approximately 3.0 percent of the power transmitted during peak load conditions.

In a tightly integrated bulk transmission system, such as The Southern Company, the ability to make substantial loss reductions is limited when considering the already low-loss transmission system. This does not lessen the need to evaluate losses, since the value of losses can be significant; hence The Southern Company pursues cost-effective loss reduction options in the expansion of its transmission system. Examples of projects being pursued by The Southern Company include the operation of some of the transmission systems at a higher voltage profile, addition of new capacitors on the transmission grid, and substitution of more efficient transformers.

Of the above three projects, the heat rate improvement was the largest, yielding total carbon dioxide emissions reductions of nearly 670,000 metric tons in 1994. No reductions were reported for this project in 1995; however, reported emissions reductions for the cogeneration project totaled over 358,000 metric tons in 1995, and the bulk power transmission project produced reductions of more than 168,000 metric tons.

abled automated operation and improved control of steam temperature, excess oxygen, gas temperature, and reheat spray. Union Electric reported an estimated 0.56-percent improvement in the heat rate as a result of the project. Reported emissions reductions were 12,648 metric tons.

Cogeneration. A total of 10 cogeneration projects were reported this year, up from 7 in the previous reporting cycle. Average carbon dioxide emissions reductions 
resulting from these projects were about 145,000 metric tons in 1995, making cogeneration projects the largest of the various efficiency improvement projects, but smaller than the carbon content reduction projects described in the preceding section. ${ }^{13}$ Some of the industrial partners in the cogeneration projects included a grain processor, a greenhouse, a chemical plant, a food processing plant, and a paper mill. Seven of the projects used natural-gas-fired cogeneration systems, one used oil and gas, and one used coal. ${ }^{14}$ Reported end uses of the thermal energy included electricity generation, process heat applications, and space heating/cooling.

The three new projects reported this year include one undertaken by a new reporter, Duquesne Light Company, and two undertaken by previous reporters, Bountiful City Light \& Power and General Public Utilities Corporation (GPU). Bountiful City Light \& Power, a municipal utility serving the town of Bountiful, Utah, uses the excess hot water produced by its natural gas and diesel generators to provide space heating for the power plant, as well as a warehouse, truck bay, and office complex owned by the utility. GPU's new cogeneration project utilizes a 200-kilowatt/235-kilovolt phosphoric acid fuel cell fueled by natural gas. In addition to generating premium quality power for dedicated lines, the cogeneration system provides thermal energy for heating and cooling applications. In 1995, the fuel cell generated 825 megawatthours of electricity and 48 million Btu of thermal energy. Total carbon dioxide emissions reductions resulting from the avoidance of transmission and distribution losses and the displacement of higher emitting boilers and generators was estimated by GPU at 111 metric tons.

\section{Transmission and Distribution Projects}

Transmission and distribution projects, although not as frequently reported as generation projects, were nonetheless reported in significant numbers. A total of 78 transmission and distribution projects were reported, up from 49 for 1994 (Figure 6). Many of the "new" projects were initiated before 1995; however, they were undertaken by new reporters and are hence "new" to the Voluntary Reporting Program. Only 6 transmission and distribution projects were initiated in 1995. Unlike generation projects, which typically have discrete start and completion dates, efforts such as upgrading conductors and replacing transformers are ongoing activities at electric utilities. Hence, most of the transmission and distribution efficiency improvements made in 1995 were reported as continuations of long-standing projects rather than as new projects.

In terms of average emissions reductions, transmission and distribution projects are typically somewhat smaller than generation projects. While there are numerous opportunities for improving efficiencies in the delivery of electricity, the magnitude of the efficiency gains that can be realized is limited.

The three most frequently reported types of transmission and distribution projects were (1) highefficiency transformers (including improved silicon steel and amorphous core transformers), (2) reconductoring (replacing existing conductors 'with large-diameter conductors to reduce line losses), and (3) distribution voltage upgrades (increasing the voltage at which the various segments of the system operate, to reduce line losses). Figure 6 shows the number of reported projects for each type. Installation of high-efficiency transformers was the most frequently reported type of project. A total of 31 such projects were reported-nearly double the number reported in the previous reporting year (16). Many of these projects were "hybrids," combining high efficiency transformer installation with one or more other activities (e.g., reconductoring).

Twenty-two projects involving reconductoring and 21 projects involving distribution voltage upgrades (again often in combination with other activities) were reported. Only 4 projects were classified as "general" or "other" transmission and distribution by the reporters, down from 11 in 1994. An example of "other" projects is American Electric Power's application of an "openloop" technique to reduce losses in ground wires. This project yielded carbon dioxide emissions reductions of nearly 1,000 metric tons in 1995.

Some of the new transmission and distribution projects undertaken in 1995 include the following:

- Wisconsin Power \& Light (WP\&L) reported on a transmission line improvement project. As stated on Form EIA-1605, "WP\&L routinely reviews loadings on transmission lines and determines where improvements can be made to reduce system losses. Losses are also reduced when new lines are installed or old lines upgraded to improve system reliability." Estimated carbon dioxide emissions reductions for this project were 9,744 metric tons in 1995.

\footnotetext{
${ }^{13}$ Estimates of average reductions across reporters should be viewed with caution, since reporters may not calculate reductions in the same way, and multiple reporters may report on some of the same activities (see Appendix B). Averages are presented only to provide a rough indication of the relative sizes of different types of projects.

${ }^{14}$ The fuel type for the remaining cogeneration project was not reported.
} 


\section{Project Profile: Allegheny Power Service Corporation's Transmission and Distribution Projects}

One of the key facts that emerges from the Form EIA1605 data is the frequent compatibility between the goals of reducing emissions and reducing costs. Many of the projects reported on Form EIA-1605 were undertaken because they were sound investments; the resulting emissions reductions are an added bonus. This is perhaps no more evident than in the case of electricity transmission and distribution projects, all of which have the goal of reducing the amount of electrical energy lost between the power plant and the end user. The resulting energy savings reduce the amount of electricity that must be generated to meet a given level of demand, hence reducing generation costs and lowering emissions.

Energy savings, however, typically come at the expense of higher capital costs. Larger diameter conductors are more expensive than smaller conductors; similarly, amorphous steel core transformers have higher purchase and installation costs than less efficient silicon steel transformers. Utilities must weigh the energy savings resulting from the use of more efficient transmission and distribution equipment against the generally higher price tag of the equipment. Nonetheless, the economic calculus often favors the more efficient equipment. How do utilities make the economic evaluations that lead to the use of more efficient equipment? Two projects described by Allegheny Power Service Corporation (APS) provide insight into the decisionmaking process for one utility:

- Shenandoah Valley Electric Cooperative reported on its purchase of energy-efficient transformers. Estimated emissions reductions for the project were 131 metric tons of carbon dioxide.

- UNICOM (Commonwealth Edison Company) reported its purchase of 12,496 transformers, yielding carbon dioxide emissions reductions of 2,114 metric tons.

In addition to the above transformer project, Shenandoah Valley Electric Cooperative-a new reporter for 1995-reported an older project involving routine upgrades to its transmission and distribution system to provide for load growth and other changes. The specific work included the conversion of two existing substations and surrounding lines to higher voltages, as well as the installation of a new substation. The resulting emissions reductions were estimated at 212 metric tons of carbon dioxide in 1993, rising to 428 metric tons in 1995. Shenandoah Valley also described work planned for 1996 through 1998, which will include the reconduc-

\begin{abstract}
Economic Conductor Selection. Subtransmission and distribution line design alternatives are evaluated based on lowest total owning cost, which includes construction costs plus the cost of electrical losses. On average, this results in a conductor one wire size larger than would be used without economic considerations. For example, the smallest wire size now used for primary distribution lines is \#2 AAAC. Before economic considerations, the smallest wire size was \#4 ACSR. Larger conductors exhibit lower losses than smaller conductors. Computer software used for line design shows specific loss values associated with different conductor alternatives.

Efficient Distribution Transformers. Distribution transformers are purchased based on lowest total owning cost which includes purchase price plus the cost of electrical losses. APS loss cost per watt is provided to transformer manufacturers prior to bidding. Manufacturers use this information to determine which design to bid. Both low price and lowest total owning cost bids are requested from manufacturers.
\end{abstract}

APS estimates that the Economic Conductor Selection project reduced carbon dioxide emissions by 4,722 metric tons in 1995, while the Efficient Distribution Transformers project yielded carbon dioxide emissions reductions of 52,336 metric tons in the same year.

toring of various lines totaling nearly 14 miles in length.

Another new reporter, Prince George Electric Cooperative, reported various transmission and distribution efficiency efforts as a single project. Specific programs included a Conductor Replacement Program (in which small-gauge, high-loss conductors are systematically identified and replaced with larger conductors), Capacitor Optimization Program (involving the efficient placement of capacitors system-wide to raise power factors and reduce losses), and their Transformer Purchase Program. Prince George Electric Cooperative also included Economic Conductor Studies in the reported project, involving comparisons of alternative conductors based on total ownership costs, including the costs of energy losses and construction and financing costs. The cooperative noted that this total cost approach typically results in the selection of a larger, more efficient conductor than that required for voltage and amperage correction, because the higher capital 
costs associated with larger conductors are more than offset by the reduced energy losses. The total carbon dioxide emissions reductions resulting from this project have increased from 29 metric tons in 1992 to 57 metric tons in 1995.

\section{Federal Voluntary Programs for the Electric Utility Industry}

Most of the electricity supply projects reported by the utility industry were undertaken at least in part to fulfill commitments made under various federally sponsored voluntary emissions reduction programs. Many of these programs have their roots in the President's Climate Change Action Plan (CCAP), which identifies nine specific action items aimed at reducing supply-side greenhouse gas emissions from the electric utility sector. These action items are designed to increase natural gas utilization, enhance the commercialization of renewable technologies, improve the performance of hydroelectric generating stations, and improve the efficiency of electricity transmission and distribution systems. ${ }^{15}$

As part of the last goal, the U.S. Environmental Protection Agency (EPA) has launched the Energy Star Transformers program. Under this voluntary program, electric utilities enter into agreements with the EPA to purchase high-efficiency distribution transformers, and manufacturers commit to produce and market Energy Star distribution transformers. Five of the electricity supply projects reported to the Voluntary Reporting Program were Energy Star Transformer projects. In the area of renewables, the U.S. Department of Energy's (DOE) Renewable Energy Commercialization program sponsors cost-shared pilot and demonstration projects with utility and industry partners. Renewable technologies covered by the program include geothermal, photovoltaics, wind, and biomass.
The cornerstone of the CCAP for electric utilities, is the Climate Challenge program. Administered by DOE, Climate Challenge is a voluntary program in which electric utilities enter into formal agreements that spell out their commitments to reduce greenhouse gas emissions or sequester carbon. The contents of these formal accords vary from utility to utility, They may, for example, include commitments to stabilize overall greenhouse gas emissions at or below 1990 levels or commitments to undertake specific greenhouse gas reduction projects. In addition to the individual utilityDOE accords, the Climate Challenge program has spawned nine separate utility industry initiatives for collective action. Examples include the Earth Comfort Program, which has the goal of increasing annual sales of energy-efficient geothermal heat pumps; the Utility Forest Carbon Management Program and its affiliated nonprofit UtiliTree Carbon Company, which are funding 5 domestic and international forestry projects; and the International Utility Efficiency Partnership, which is currently assessing projects in 18 countries. The other Climate Challenge collective initiatives include the Envirotech charter, the Combined Purchasing Initiative, EV America (electric vehicles), the Electric End Use Efficiency Technology Initiative, Tree Power, and the International Donated Equipment Initiative.

Climate Challenge participants are encouraged to report their emissions reduction activities to the EIA. The Climate Challenge program is designed to give individual utilities flexibility in identifying and pursuing the most cost-effective approaches to greenhouse gas reductions. ${ }^{16}$ There are currently 117 participants in the Climate Challenge program, representing over 60 percent of total U.S. electric generating capacity. (excluding nonutility generators), and 69 percent of 1990 utility carbon dioxide emissions. ${ }^{17}$ Most of the electricity supply projects reported to the EIA ( 90 percent of the total) were included in the reporters' Climate Challenge commitments.

\footnotetext{
${ }^{15}$ President William J. Clinton, The Climate Change Action Plan (Washington, DC, October 1993), Summary Table of Actions, Actions 2331.

${ }^{16}$ President William J. Clinton, The Climate Change Action Plan (Washington, DC, October 1993), Foundation Actions, Launch the Climate Challenge.

${ }^{17}$ U.S. Department of Energy, "Climate Challenge Executive Summary," web site www.eren.doe.gov/climatechallenge (March 19, 1997).
} 


\section{Reporting Issue: The Form ElA-1605 Standard Emissions Coefficients}

Estimating the emissions reductions achieved as a result of electricity supply projects generally involves two steps. First, the reporter estimates the amount of electrical energy or fuel saved (or displaced in the case of fuel switching). Then, the reporter converts the energy savings estimate into an emissions reduction estimate, using standard emissions coefficients. The instructions for Form ELA-1605 provide reporters with emissions coefficients for this purpose (although reporters are free to use coefficients from other sources). Two sets of emissions coefficients are provided in the instructions. The first set provides coefficients for fuels (e.g., bituminous coal, subbituminous coal, diesel fuel, natural gas). For each fuel type, a coefficient is provided in pounds of $\mathrm{CO}_{2}$ per million Btu; in addition, a second coefficient is provided on a per weight or volume basis (e.g., pounds of $\mathrm{CO}_{2}$ per ton of bituminous coal). These "fuel-based" emissions coefficients can be used whenever the reporter knows the type of fuel saved and has estimated the project's fuel savings in Btu (or on a weight or volume basis).

The second set of coefficients are referred to in the instructions as "Adjusted Electricity Emission Factors." Three separate emissions factors are provided for each State, in pounds of $\mathrm{CO}_{2}$ per kilowatthour, short tons of $\mathrm{CO}_{2}$ per megawatthour, and metric tons of $\mathrm{CO}_{2}$ per megawatthour. These State-level emission factors can be applied to estimates of electrical energy saved, in kilowatthours or megawatthours.

The two sets of emissions coefficients provided in the Form EIA-1605 instructions are by no means equal. The fuel-based coefficients-intended as the primary coefficients, to be used whenever possible-are in general highly accurate and were derived from laboratory analyses of the carbon and heat contents of the different fuel types. Although the ratio of a fuel's carbon content to its heat content exhibits some variation, the variability is generally confined to a narrow range. Hence, the fuel-based coefficients can be applied to virtually all U.S. fuels with highly accurate results. It should be noted, however, that the coefficients expressed on a per million Btu basis are in general more accurate than the weight- or volumebased coefficients, particularly in the case of coal, which shows little variability in the ratio of carbon content to heat content but wide variations in the amount of carbon per ton, even within a particular coal rank.

The adjusted electricity emission factors, on the other hand, are much less accurate than the fuel-based co- efficients. These factors represent State-level averages reflecting the mix of fuels used to generate electricity throughout each State, although the actual fuel mix used by particular utilities within a State varies widely, depending on the energy resources available to each utility, the time of day, and the season. Thus, emissions reduction estimates derived using the Statelevel adjusted electricity emissions factors should be viewed as no more than rough approximations. These factors are intended for use only as a last resort, when the reporter has an estimate of the amount of electrical energy saved by a project but cannot determine the type(s) and amount of fuel saved.

Such situations arise frequently, because it is often difficult if not impossible to identify the specific power plants affected by a project. Consider, for example, the case of transmission and distribution projects. The energy saved as a result of such a project reduces the amount of power that must be generated to meet demand; the generation reduction will actually occur at the utility's marginal power plant. But the particular power plant operating at the margin changes constantly, depending on the time of day, the season, planned and unplanned outages, etc. Furthermore, the marginal power plant is often a plant owned by another utility selling wholesale power to the utility that undertook the project, and the buyer may have no knowledge of the specific power plants that generated the purchased power.

Still, the utility often has at least some information that enables it to make reasonable assumptions. For example, a utility that undertakes an availability improvement project at its nuclear plant may assume that the resulting increased generation displaces baseload coal-fired plants except during peak load periods, when it displaces gas-fired units. From this assumption, the utility can estimate the amount of coal and gas saved as a result of the project and apply the fuel-based emissions coefficients to derive emissions reductions. Such an approach, based on a reasonable, informed assumption, will generally yield a more accurate result than the alternative-i.e., simply applying the State-adjusted electricity emissions factor to the increased nuclear generation without attempting to approximate the specific fuel types affected. Although some reporting utilities do rely on the adjusted electricity emission factors, many, if not most, use the "reasonable assumption" approach that allows application of the more accurate fuel-based emissions coefficients. 


\section{Increasing End-Use Energy Efficiency}

Energy use in the residential, commercial, and industrial sectors account for more than 3.49 billion metric tons of carbon dioxide emissions per year-about twothirds of U.S. carbon dioxide emissions. This total includes about 1.8 billion metric tons of emissions from the generation of electricity consumed by each of the three sectors. Industry is the largest of the three sectors in terms of emissions, accounting for nearly half the total; the residential sector accounts for about 29 percent of total emissions, and the commercial sector contributes an additional 22 percent. $^{18}$

Between 1990 and 1995, carbon dioxide emissions associated with industrial, residential and commercial energy use increased by 4.3 percent. The residential sector is the fastest-growing emissions source, having registered a 7.5 percent emissions increase between 1990 and 1995. Emissions from the commercial sector increased by 3.2 percent over the same period, while industrial sector emissions rose by 3.0 percent. This upward trend in emissions across all three sectors reflects U.S. economic growth and corresponding increases in energy consumption. However, end-use energy emissions grew at a slower rate than energy consumption (7.3 percent between 1990 and 1995), which in turn grew at a slower rate than the U.S. economy (10.5 percent). Factors that helped to slow the growth in emissions included efficiency and other improvements in the supply of electricity (see Chapter 2) as well as end-use efficiency gains. ${ }^{19}$

\section{Projects Reported}

Energy end-use projects accounted for 28 percent of all projects reported for 1995, second only to electricity supply projects (in number of projects reported). The 276 reported energy end-use projects represent a 33percent increase over the number reported for 1994. A total of 91 entities reported energy end-use projects, 63 of them on the long form. Most (83) of these entities were utilities. The remaining reporters included a nonprofit forestry organization (American Forests), a printing company (Quad/Graphics, Incorporated), a pharmaceutical company (Johnson \& Johnson), a metals fabricator (Majestic Metals, Incorporated), an automobile manufacturer (General Motors), a defense/ aerospace firm (Lockheed Martin), a university (the Rochester Institute of Technology), and one private household.

Only 20 new energy end-use projects were initiated in 1995, down from 34 in 1994 and 62 in 1993. This may reflect the fact that most of the reported end-use projects ( 88 percent of the total ${ }^{20}$ ) are demand-side management (DSM) programs sponsored by electric utilities. Most utilities introduced their DSM programs in the late 1980s and early 1990s; hence, the bulk of DSM projects reported this year represent established, ongoing programs.

Carbon dioxide emissions reductions reported for individual projects ranged from less than 1 metric ton to more than 1 million metric tons, primarily because of the flexibility allowed in defining the scope of a project. Projects could range from the installation of a compact fluorescent light bulb reported by a household, up to a system-wide DSM program reported by a large utility. Nonetheless, like most other project types, energy enduse projects tended to fall in the emissions reduction range of 0 to 100,000 metric tons carbon dioxide equivalent (Figure 7). Ninety percent of the end-use projects yielded emissions reductions in this range in 1995. Twenty-four large projects yielded emissions reductions between 100,000 and 1 million metric tons, and three very large projects yielded reductions in excess of 1 million metric tons.

\section{Project Types}

Most of the reported projects are "hybrids" that target multiple end uses; this is particularly true of the

\footnotetext{
${ }^{18}$ In terms of their contribution to overall energy-related carbon dioxide emissions, the industrial sector leads with a 33-percent share of the total, followed by the residential sector (19 percent) and the commercial sector (16 percent). Transportation, which is considered in the next chapter, accounts for the remaining 33 percent.

${ }^{19}$ Energy Information Administration, Emissions of Greenhouse Gases in the United States 1996, DOE/EIA-0573(96) (Washington, DC, October 1997), pp. 11-19.

${ }^{20}$ This percentage includes in-house utility demand-side management programs aimed at reducing the utilities' own energy consumption.
} 
Figure 7. End-Use Projects by Project Size

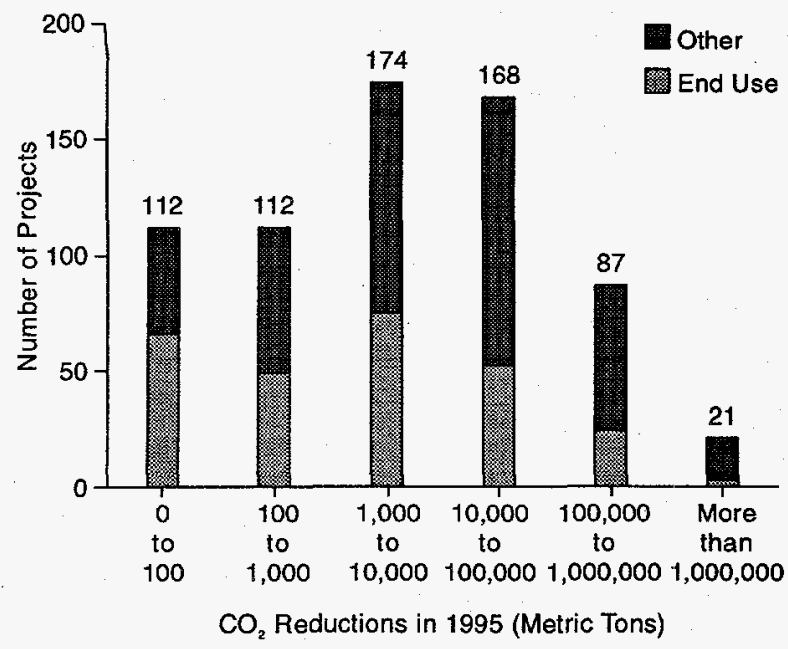

Source: Energy Information Administration, Forms EIA-1605 and ElA-1605EZ, "Voluntary Reporting of Greenhouse Gases."

various DSM programs reported by electric utilities. Nonetheless, end-use projects most frequently targeted lighting and lighting controls, followed by equipment and appliances and heating, ventilation, and airconditioning (HVAC) (Figure 8). These three types of projects also showed the most growth in terms of numbers reported since the last reporting cycle.

The prevalence of projects involving lighting, equipment and appliances, and HVAC reflects the importance of these three energy end uses in the United States. Space heating, ventilation and air conditioning is the primary energy end use in both the residential sector (where it accounts for about 58 percent of total energy use ${ }^{21}$ ) and the commercial sector ( 45 percent of total energy consumption ${ }^{22}$ ). Furthermore, the potential for reducing the amount of energy consumed by HVAC equipment is considerable. Consider, for example, that new homes (constructed between 1988 and
Figure 8. End-Use Projects by Project Type

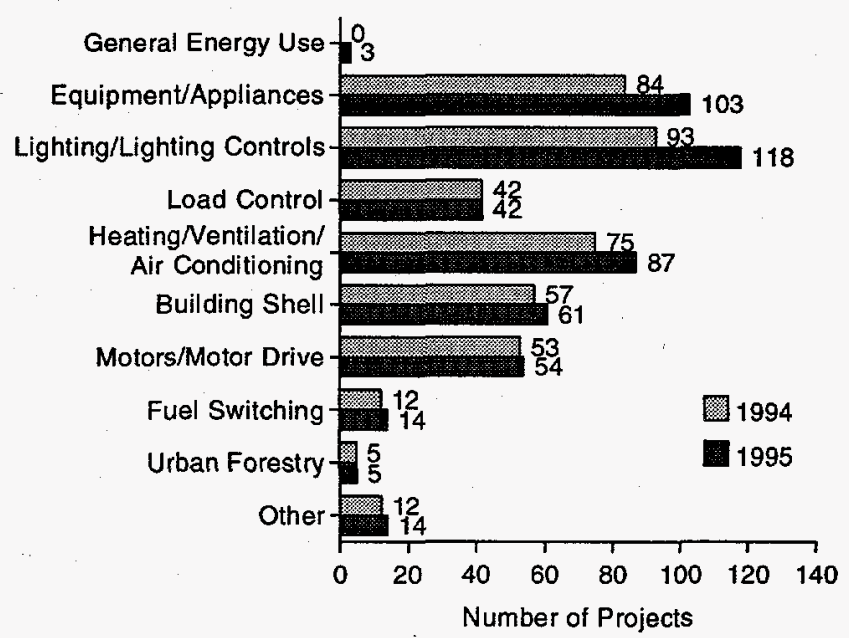

Notes: Excludes energy end-use projects reported on Form EIA$1605 E Z$. Some projects may be counted in more than one category.

Source: Energy Information Administration, Form ElA-1605, "Voluntary Reporting of Greenhouse Gases."

1993) use only 79 percent of the electricity consumed by old (pre-1988) homes for space heating and 88 percent of the electricity used by old homes for air conditioning -in part because they are more likely to use highefficiency HVAC equipment, such as heat pumps. ${ }^{23}$

Energy consumed by equipment and appliances accounts for 39 percent of the U.S. total in the residential sector ${ }^{24}$ and about one-fourth of the total in the commercial sector. ${ }^{25}$ Lighting is a less significant energy end use in the residential sector (accounting for only about 3 percent of the total), ${ }^{26}$ but it is important in the commercial sector, where it accounts for 18 percent of total energy consumed and 29 percent of total energy expenditures. ${ }^{27}$ Reducing these disproportionately high expenditures is no doubt a motive behind many of the lighting projects reported for the commercial sector.

\footnotetext{
${ }^{21}$ Estimated from data contained in Energy Information Administration, Household Energy Consumption and Expenditures 1993, DOE/EIA0321(93) (Washington, DC, October 1995).

${ }^{22}$ Energy Information Administration, Energy End-Use Intensities in Commercial Buildings, DOE/EIA-0555(94)/2 (Washington, DC, September 1994), p. 7.

${ }^{23}$ Energy Information Administration, Household Energy Consumption and Expenditures 1993, DOE/EIA-0321(93) (Washington, DC, October 1995), p. 15.

${ }^{24}$ Estimated from data contained in Energy Information Administration, Household Energy Consumption and Expenditures 1993, DOE/EIA0321(93) (Washington, DC, October 1995).

${ }^{25}$ Energy Information Administration, Energy End-Use Intensities in Commercial Buildings, DOE/EIA-0555(94)/2 (Washington, DC, September 1994), p. 7.

${ }^{26}$ Estimated from data contained in Energy Information Administration, Household Energy Consumption and Expenditures 1993, DOE/EIA0321(93) (Washington, DC, October 1995).

${ }^{27}$ Energy Information Administration, Energy End-Use Intensities in Commercial Buildings, DOE/EIA-0555(94)/2 (Washington, DC, September 1994), pp. 7 and 11.
} 


\section{Project Profile: Lockheed Martin's Motor Challenge Project}

As part of the U.S. Department of Energy's Motor Challenge program, a limited number of companies have been selected to showcase energy-efficient motor systems. One is Lockheed Martin, a major U.S. defense contractor and aerospace firm. Lockheed Martin describes the ongoing Motor Challenge project at its Lakeside Avenue industrial plating plant in Burlington, Vermont, as follows:

Lockheed Martin Armament Systems was looking for a way to improve the performance of the ventilation system [at the plant]. By utilizing variable frequency drives (VFDs) and making other modifications to the system, they were able to improve the plant's overall operating efficiency, reduce costs, and improve the work environment and worker health and safety. This Motor Challenge Showcase Demonstration Project has resulted in annual savings of more than $\$ 68,000$, with a payback of just under one and a half years.... .

Concerned with rising overhead rates, Lockheed Martin management targeted energy expenditures as a prime opportunity for cost savings. At the Burlington facility, electrical costs are more than 10 cents per kilowatthour, the highest of any Lockheed Martin plant in the country.

The previously existing ventilation system, which has been in use for more than 25 years, was de-

For the second year, end-use projects in the residential and commercial sectors outnumbered those in the industrial sector, which, in turn, greatly outnumbered agricultural projects (Figure 9). The number of projects reported in the commercial sector increased by 43 percent relative to the last reporting cycle, and residential and industrial sector projects also saw significant growth, whereas the number of projects reported for the agricultural sector dropped from 25 to 24 . It should be noted that many projects-particularly utility DSM programs-cover more than one end-use sector.

On average, industrial sector projects yielded slightly larger carbon dioxide emissions reductions than projects involving the commercial and residential sectors. Whereas HVAC and lighting represent major end uses in the latter two sectors, less than 8 percent of the energy consumed by U.S. manufacturers is used for facility support (including HVAC and lighting). Energy consumed by the manufacturing sector is used mainly in direct process applications (which account for over half of all energy utilized). Process heating is the primary direct process application, accounting for more signed for continuous 24-hour operation. Currently, however, the plant only operates one shift per day....

During the installation of the VFDs, Lockheed Martin also decided to install a new energy management system (EMS) in conjunction with the VFDs. This was done so that the motors could be controlled as a system. The EMS also allows a trending capability and has the capacity to control the entire facility.

The new variable-output ventilation system includes nine electronic VFDs which reduce ventilation during idle times . . . . Flow has been reduced to 55-65 percent of full speed during idle times ...

Benefits of the new system include a 38 percent cost reduction in electric and natural gas utilities, emergency ventilation control, fewer emissions, and improved system control. The project cost was approximately $\$ 99,400$ to implement and has resulted in annual savings of more than $\$ 68,000$, providing a simple payback of just under 1.5 years. Key to this low payback is the dramatic reduction in VFD costs over the last few years....

Estimated carbon dioxide emissions reductions for the project were 215 metric tons in 1995.
Figure 9. End-Use Projects by Sector

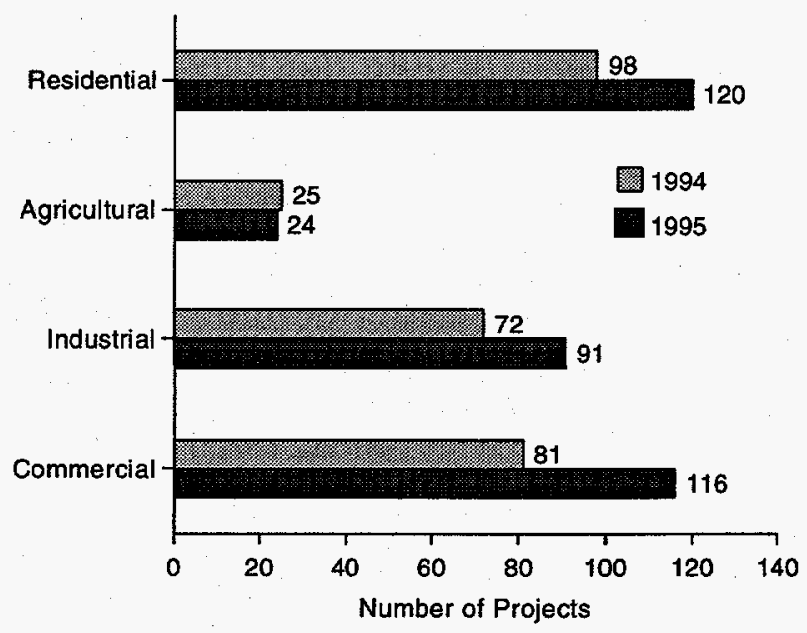

Notes: Excludes energy end-use projects reported on Form EIA$1605 E Z$. Some projects may be counted in more than one category. Source: Energy Information Administration, Form ElA-1605, "Voluntary Reporting of Greenhouse Gases." 
than one-third of all energy consumed by manufacturing establishments. Motors and motor drives are also an important end use, with about a 13-percent share of total consumption. ${ }^{28}$ Fifty-four projects involving motor/motor drive efficiency improvements were reported to the Voluntary Reporting Program.

Many of the utility DSM programs reported on Form EIA-1605 have multiple load shape objectives; however, simply improving energy efficiency is at least one of the objectives for a majority of the reported DSM programs (Figure 10). Peak clipping was the second most frequently reported load shape objective, and load shifting was the third.

\section{Figure 10. End-Use Projects by Load Shape Objective}

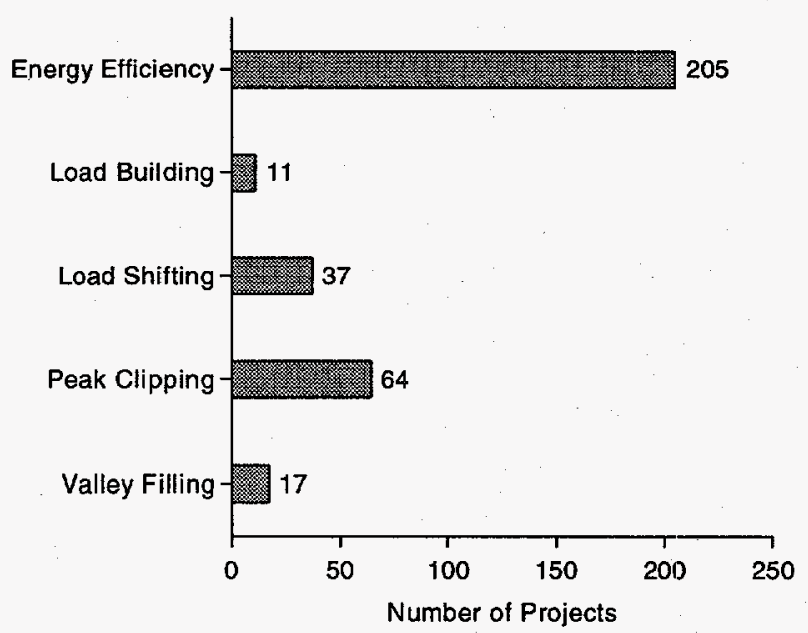

Notes: Excludes energy end-use projects reported on Form EIA1605EZ. Some projects may be counted in more than one category.

Source: Energy Information Administration, Form EIA-1605, "Voluntary Reporting of Greenhouse Gases.”

\section{New Projects and New Reporters}

Opportunities for reducing emissions through improvements in end-use efficiency are almost as varied as the types of energy end uses themselves. A consideration of the new projects reported this cycle provides some sense of the extent and variety of emissions reduction options available. Of the 20 new end-use projects initiated in 1995, 5 were undertaken by Johnson \& Johnson:

- A building shell project involving facility audits and thermal integrity improvements, such as the installation of window film and insulation

- An equipment and appliances project, aimed at heaters, office and manufacturing support equipment, and power conditioning equipment:

\section{Utility DSM Load Shape Objectives}

Utility DSM programs may have a number of different objectives beyond simply improving energy efficiency. Some DSM programs have the objective of altering load shapes. For example, programs aimed at peak clipping seek to reduce energy consumption at certain critical times, typically when the utility experiences system peaks. Load shifting programs have the objective of shifting energy consumption from one time of day to another, typically from peak to off-peak periods. Although (unlike the case for peak clipping) overall energy consumption is not necessarily reduced by load shifting, emissions reductions may nonetheless occur, depending on the types of fuel used during peak and off-peak periods. For example, load shifting will reduce emissions if hydropower is used to meet baseload demand and natural gas-fired generators are used as peaking units. Similarly, load building programs, which seek to increase electricity consumption (e.g., through the promotion of industrial electrotechnologies) may reduce emissions if the increased electricity demand displaces higher emitting energy sources. Valley filling, which is aimed at increasing off-peak electricity consumption, may also reduce emissions, depending on the energy sources displaced.

- An HVAC project, involving measures such as the use of energy management systems and boiler/ chiller upgrades

- A load control project

- A motor efficiency project.

Johnson \& Johnson undertook the above projects as part of its efforts under a number of voluntary emissions reduction programs, including DOE's and EPA's Climate Wise, EPA's Energy Star Buildings, and DOE's Motor Challenge. Taken together, the five projects reduced carbon dioxide emissions by an estimated 5,145 metric tons in 1995.

Next to Johnson \& Johnson, PacifiCorp led the reporters in terms of the number of new end-use projects undertaken in 1995, with a total of four. These projects included one conducted in conjunction with CES/Way, an energy conservation contractor. CES/Way performs detailed engineering analyses of commercial, government, and institutional facilities and recommends energy efficiency improvements. The measures evaluated include energy management control systems and

${ }^{28}$ Energy Information Administration, Manufacturing Consumption of Energy 1991, DOE/EIA-0512(91) (Washington, DC, December 1994), pp. 18-19. 


\section{Reporter Profile: Seattle City Light}

Seattle City Light is a municipal utility serving the city of Seattle, Washington. For 1995 it reported on 10 separate DSM projects with a variety of incentives and methods to encourage energy efficiency and conservation in the residential, commercial, and industrial sectors. Many were undertaken in conjunction with the Bonneville Power Administration (BPA). Eight of the projects are described below.

Energy \$avings Plan (E\$P). This project was originally funded directly by the BPA, but in September 1991 Seattle City Light signed a contract with the BPA to market the program. $\mathrm{E} \$ \mathrm{P}$ is an incentive program to encourage energy savings in the industrial sector. The program provides funding for energy audits, financial incentives for energy conservation, and rebates for energy-efficient motors. The eligible population for this program includes Seattle City Light's 293 industrial customers.

Energy-Efficient Water Heater Rebate Program. This program, operated in conjunction with the BPA, is designed specifically to increase the installation of energy-efficient electric water heaters when old water heaters are replaced. If the new water heater meets the specified energy efficiency standards, the customers receives a rebate of $\$ 30$. Originally the program targeted the residential sector, but in 1994 it was expanded to include commercial customers with water heaters smaller than 120 gallons. The program currently leads the northwestern region in the number of energy-efficient water heaters installed.

Home Water Savers Program (HWSP). Under this program, Seattle City Light, in cooperation with the Seattle Water Department and Puget Sound Power and Light Company, distributed free home water savers kits to 147,000 residences with electric water heaters. Each kit included an efficient-flow showerhead, a bathroom faucet aerator, a toilet flow device, and toilet leak detection tablets. Installation was also provided for elderly and disabled customers and, beginning in November 1992 and continuing until 1994, for multifamily buildings with five or more units. Installation services were provided by the Seattle Conservation Corps, the Seattle Water Department, and the Seattle Housing Authority, as well as building owners. Two surveys conducted after the original kit distribution indicated that, excluding free riders, 56 percent of single-family residences had installed the showerheads and 40 percent had installed the bathroom faucet aerators. Seattle City Light estimates that the average single-family residence saved 300 kilowatthours per year by using the efficient-flow showerhead and 65 kilowatthours per year by using the faucet aerator, representing approximately 3 percent of the total energy used by the typical single family residence with electrically heated water. The typical multiplex (two- to four-unit) residence saved an estimated 200 kilowatthours per year for each showerhead and 80 kilowatthours for each the faucet aerator, corresponding to 2 percent of the total energy used by such residences. Finally, the average multifamily (five or more units) residence saved 200 kilowatthours per year per showerhead and 170 kilowatthours per year per faucet aerator, corresponding to 5 percent of the total energy consumed by such residences. Supporting partners in this project included the BPA, the Municipality of Metropolitan SeattleMetro (waste water), and the Washington Natural Gas Company.

Long-Term Super Good Cents Program. This is a "beat the code" financial incentive program designed to encourage builders of new multifamily residential dwellings to employ more efficient construction practices. Incentives are paid for buildings that meet the specified goals in the areas of building shell, lighting, and appliances such as water heaters, refrigerators, and showerheads. Partial funding for the program was provided by the BPA up until 1996, when Seattle City Light took over full funding. Based on an evaluation completed in 1996, Seattle City Light estimated the annual average energy savings per residential unit to be 2,350 kilowatthours for buildings completed in 1993-94. The savings break down as follows: 1,090 kilowatthours in space heat savings, 65 kilowatthours in internal (within unit) lighting savings, and 1,195 kilowatthours in common area lighting savings. Units that received efficient refrigerators were assumed to save an additional 120 kilowatthours per year.

Low-Income Electric Program (LIEP). This program provides weatherization grants to households for building and water heater insulation, water heater thermostat setbacks, caulking, weatherstripping, and smoke detectors. LIEP targets low-income singlefamily homes and small (two- to four-unit) multiplexes with electric space heating. The program is administered jointly with the Department of Housing and Human Services. The estimated energy savings per home averaged 2,450 kilowatthours per year for single-family residences and 1,308 kilowatthours per year for multiplex buildings. 


\section{Reporter Profile: Seattle City Light (Continued)}

Multifamily Conservation Program-Standard Income. This program provides financial and technical help to apartment owners for improving building insulation, lighting and water heating. It is partially funded by the Bonneville Power Administration. The standard-income program targets an eligible population of 2,373 buildings with 47,461 units. Seattle City Light's goal is to bring 62 percent of the eligible population into the program.

Multifamily Conservation Program-Low Income. This program targets low-income households. On average, participants in both the standard-income and low-income programs saved an estimated 1,490 kilowatthours per residential unit per year in 1992. An additional average of 390 kilowatthours per unit was saved through common area lighting measures. The eligible population for the low-income program includes 791 low-income buildings with a total of 15,820 units.
Warm Home Program. The Warm Home Program provides grants and loans for weatherizing electrically heated homes. The program is marketed by private contractors paid and managed by Seattle City Light. Insulation is provided at no cost, and a grant of $\$ 3$ per square foot plus a loan of up to $\$ 12$ per square foot is provided for insulated windows. Average annual energy savings were reported as 2,664 kilowatthours for single-family residences and 2,044 kilowatthours per unit for multiplex residences.

Total estimated emissions reductions for all 10 reported projects (including 2 not described above) increased more than threefold between 1992 and 1995, from 29,697 metric tons to 105,043 metric tons. The projects saved an estimated 267,782 megawatthours in 1995, equivalent to 3.8 percent of Seattle City Light's total 1995 electricity generation (based on data from the Energy Information Administration's Electric Power Monthly, DOE/EIA-0226, various issues). retrofits of motor, lighting, shell insulation, and HVAC systems. CES/Way provides up-front funding for the recommended measures, with repayment from PacifiCorp and the customer, based on the verification of energy savings.

Duquesne Light Company reported its 10-percent share of a joint research project on thermal storage that was initiated in March 1995. The project involves a thermal storage system installed in a Carnegie Mellon University Research Institute building. The system stores chilled water during off-peak evening hours, for use in space cooling during business hours.

Union Electric Company reported its 15.9-percent share in the EnviroTech Fund, an investment program that supports the development of energy-efficient technologies. The fund is managed by Advent International Corporation, in cooperation with the Edison Electric Institute. Advent International uses the fund to invest in promising technologies. New investments are expected over the next several years.

In addition to the above projects, which were initiated in 1995, a number of older projects were reported for the first time by new reporters. Rochester Institute of Technology (RIT) reported on nine separate projects, including the conversion of 1,257 exit signs to LED signs in 41 buildings, the installation of 1,562 occupancy sensors, and a number of projects involving the installa- tion of 32-watt T-8 lamps and electronic ballasts in various buildings on the campus. The university estimated its total energy savings for all of these projects at 2,679 megawatthours in 1995. Assuming electricity costs between $\$ 0.05$ and $\$ 0.09$ per kilowatthour, the corresponding monetary savings can be estimated at roughly $\$ 135,000$ to $\$ 240,000$. RIT estimated the total carbon dioxide emissions reductions for the nine projects at 1,259 metric tons for 1995.

Duquesne Light Company reported on a DSM project that has evolved over the years from a "heating approach" to an "end-use approach." The program was originally intended to reduce the electricity bills of lowincome customers through the provision of weatherization services; however, because the use of electric resistance heating was relatively limited among the targeted low-income customers, Duquesne Light changed the program's focus to encompass a broader array of end uses. The utility provides program participants with various no-cost services, including advice on reducing energy bills and installation of energyefficient technologies such as compact fluorescent lamps. Refocusing the program appears to have had.a significant positive impact. Estimated project energy savings grew from 3,974 megawatthours in 1992 to 9,935 megawatthours in 1995, and carbon dioxide emissions reductions increased from 3,064 metric tons to 7,661 metric tons over the same period. 


\section{Federal Voluntary Programs To Increase End-Use Energy Efficiency}

Most of the reported end-use projects were undertaken in conjunction with various Federal voluntary emissions reduction programs. The President's Climate Change Action Plan (CCAP) includes 18 different action items aimed at reducing energy demand through efficiency improvements and conservation. In the industrial sector, 7 action items seek to accelerate efficiency improvements in motors, compressors, pumps, fans, and process technologies, to promote source reduction and recycling, and to reduce the amount of energy used in the manufacture of fertilizers (by reducing fertilizer usage). In the commercial sector, CCAP includes 5 action items aimed at improving the energy efficiency of commercial buildings, demonstrating emerging energy efficiency and renewables technologies, and providing the building industry with information and training on renewable and energy efficiency options. In the residential sector, 6 action items are designed to improve the efficiency of houses and home appliances. ${ }^{29}$

The Federal Government sponsors a wide variety of programs aimed at reducing greenhouse gas emissions by lowering energy consumption. Some were created under the Climate Change Action Plan; others predate CCAP. The EPA's various Energy Star programs seek to improve the efficiency of buildings and appliances through such means as certifying equipment that meets EPA specifications with the Energy Star label. The Energy Star programs include Energy Star Buildings, Energy Star Homes, Energy Star Exit Signs, Energy Star Office Equipment, and Energy Star Residential Heating and Cooling. Eight Energy Star Building projects and one Energy Star Computers project were reported to the Voluntary Reporting Program for 1995.

Other voluntary programs include:

- DOE's Building America program, which is aimed at researching and testing systems engineering approaches to improving the energy efficiency of residential buildings. Project funding is 50 percent cost-shared with industry participants

- DOE's Cool Communities program, which encourages the use of lighter wall and roof colors and the planting of shade trees around buildings, through technical assistance and education

- DOE's Rebuild America program, under which participating communities agree to develop and implement Action Plans for energy-efficient retrofits of existing buildings
- DOE's Energy Efficiency and Renewable Energy Information and Training programs, which are aimed at the building industry

- DOE's Energy Fitness program, which seeks to identify and remove barriers (e.g., information barriers) to increasing the delivery of energyefficient technologies to energy service companies

- EPA's Green Lights program, under which participants commit to surveying their facilities and upgrading their lighting where profitable within 5 years (29 Green Lights projects were reported to the Voluntary Reporting Program for 1995)

- DOE's Energy Analysis and Diagnostic Centers (3 projects reported)

- DOE's Motor Challenge program, under which industrial participants showcase energy-efficient motor systems installed with technical assistance from DOE and EPA (4 projects reported)

- The NICE ${ }^{3}$ Industrial Pollution Prevention Grants program (jointly sponsored by DOE, EPA, and the Department of Agriculture), which provides grants to prevent pollution and improve energy efficiency

- EPA's Waste Wi\$e program, which encourages businesses and State, local, and tribal governments to reduce waste through waste prevention, collection of recyclables, and the purchase of recycled products ( 1 project reported to the Voluntary Reporting Program for 1995).

Finally, the analog of the Climate Challenge Program within the industrial sector is the Climate Wise Recognition Program, jointly supported by DOE and EPA. Participating companies enter into agreements to reduce greenhouse gas emissions. The specifics of these agreements vary for each participant, but they may, for example, include commitments to undertake specific emissions reduction projects, or to reduce overall company emissions to 1990 levels. Current participants include DuPont, General Motors, Johnson \& Johnson, and Quad/Graphics, among others. Climate Wise companies are encouraged to report on Form EIA-1605. Eight of the energy end-use projects reported this year were Climate Wise projects, and 221 ( 80 percent) were Climate Challenge projects. The dominance of Climate Challenge projects reflects the fact that the majority of energy end-use projects were reported by electric utilities.

${ }^{29}$ President William J. Clinton, The Climate Change Action Plan (Washington, DC, October 1993), "Summary Table of Actions." 


\section{Reporting Issue: "Basic" and "Modified" Reference Cases}

In order to estimate the emissions reductions resulting from an energy end-use project, reporters must compare current energy use (with the project) to some baseline usage level (without the project). The difference represents the amount of energy saved. The baseline usage level employed as the point of comparison is referred to as the reference case. Reporters have a choice between basic and modified reference cases. In a basic reference case, the point of comparison is the reporter's historical energy use before the project. In a modified reference case, the point of comparison is an estimate of what the reporter's energy use would have been without the project.

It may appear that a basic reference case will yield a more accurate, "real" estimate of emissions reductions than a modified reference case. The basic reference case is a historical value, which can be (at least in theory) directly measured. The modified reference case, on the other hand, is always by necessity a "what if" estimate of energy usage in the absence of the project. A modified reference case may yield emissions reductions even when emissions have increased from their historical level. Thus, reporters who have committed to reducing their total emissions below 1990 levels under the Climate Challenge or Climate Wise program should use a basic reference when reporting their entity-level emissions reductions. In this case, the objective of computing emissions reductions is to measure progress by comparison to a historical emissions level.

On the other hand, the modified reference case is usually more appropriate for computing project-level reductions. For many new projects there are no historical emissions to be compared with current emissions. Also, it is rarely possible to "screen out" the effects of factors unrelated to the project. Energy end-use projects-particularly utility DSM projectsprovide good examples.

Consider the problem of "free riders," defined as utility DSM participants who would have taken the utility-sponsored energy saving measures irrespective of the DSM program (e.g., customers who would have purchased an energy-efficient appliance even had they not received a rebate from the utility). Since by definition their actions are not influenced by DSM programs, the energy saved by free riders should be excluded from estimates of DSM program savings. With a modified reference case, the energy that would have been consumed by the participants in the absence of the DSM program can be estimated, and the energy savings for free riders can be computed as zero. Changes in energy consumption caused by weather provide another example of the advantages of the modified reference case, which can control for the effects of weather. A basic reference case does not provide this flexibility.

In summary, the purpose of the emissions reduction estimate should be considered when a reference case is selected. For estimating emissions reductions caused by a project, the modified reference case is typically preferable to the basic reference case. For 1995, most Form EIA-1605 reporters did use modified reference cases for estimating their project-level emissions. 


\section{Reducing Oil-Based Transportation Fuel Use}

\section{U.S. Transportation Emissions}

The transportation sector currently produces about onethird of U.S. carbon dioxide emissions and is expected to be the fastest growing source of this gas through the year 2000 (Figure 11). Carbon dioxide results from the combustion of fossil fuels, including gasoline, diesel, jet fuel, and natural gas. Emissions from the transportation sector currently exceed 1,680 million metric tons of carbon dioxide annually. ${ }^{30}$ Nearly 80 percent comes from the consumption of motor gasoline and distillate (diesel) fuel (Figure 12), over 95 percent of which is used in highway vehicles. ${ }^{31}$

Carbon dioxide emissions from fuel combustion increased by 21 percent between 1980 and 1995, largely as

\section{Figure 11. Trends in Carbon Dioxide Emissions from the U.S. Transportation Sector, 1980-2015}

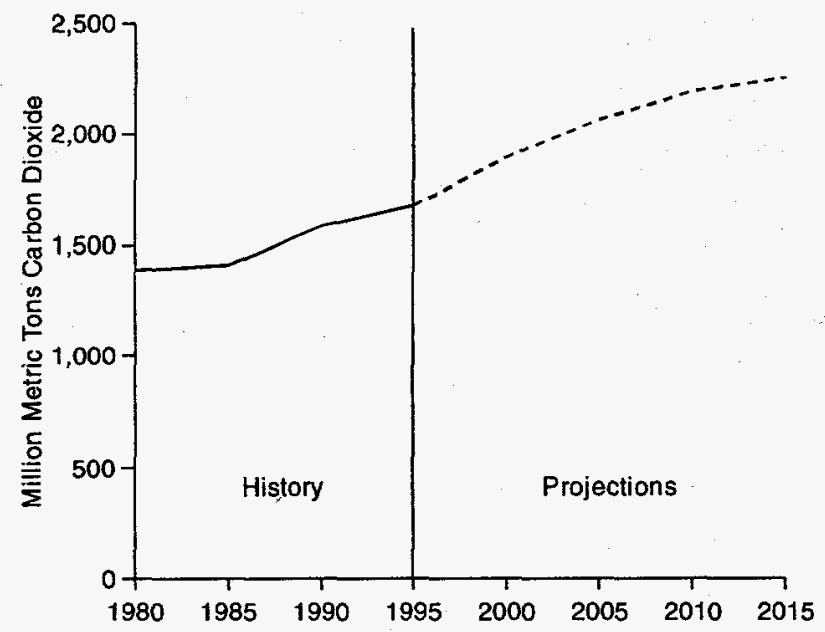

Sources: History: 1980 and 1985-Energy Information Administration (E|A), Annual Energy Review 1995, DOE/EIA-0384(95) (Washington, DC, July 1996), p. 333. 1990 and 1995-EIA, Emissions of Greenhouse Gases in the United States 1996, DOE/EIA-0573(96) (Washington, DC, October 1997), p. 20. Projections: ElA, Annual Energy Outlook 1997, DOE/EIA-0383(97) (Washington, DC, December 1996), p. 120. the result of a corresponding increase in highway vehicle usage (Figure 13). Between 1980 and 1995, the number of registered vehicles and the average miles traveled per vehicle increased by 27 percent and 25 percent, respectively. Vehicle miles traveled increased by 59 percent, reaching nearly 2.5 trillion miles in 1995. This increase has translated directly into higher carbon dioxide emissions, which have been mitigated somewhat by a 27-percent increase in average fuel efficiency, from 13.29 miles per gallon in 1980 to 16.91 miles per gallon in 1995.

\section{Projects Reported}

\section{Overview}

A total of 50 transportation projects were reported for 1995 by 34 entities, 32 of which (94 percent) were electric utilities. The two nonutilities were Majestic Metals, Inc., a fabricated metal product manufacturer,

\section{Figure 12. Transportation Sector Carbon Emissions by Fuel, 1995}

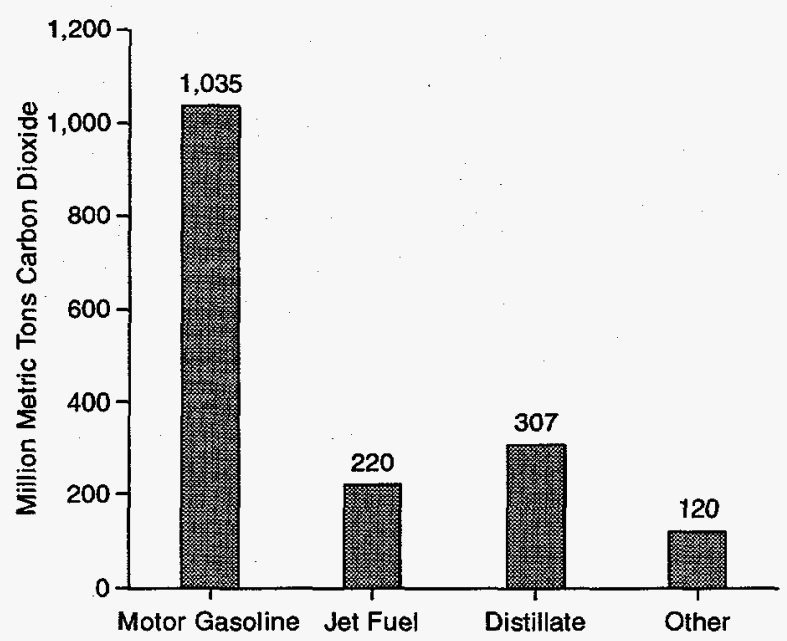

Source: Energy Information Administration, Emissions of Greenhouse Gases in the United States 1996, DOE/EIA-0573(96) (Washington, DC, October 1997).

\footnotetext{
${ }^{30}$ Energy Information Administration, Emissions of Greenhouse Gases in the United States 1996, DOE/EIA-0573(96) (Washington, DC, October 1997), p. 12.

${ }^{31}$ U.S. Department of Transportation, Bureau of Transportation Statistics, National Transportation Statistics 1997, DOT-VNTSC-BTS-96-4 (Washington, DC, December 1996), Table-4-3, p. 161.
} 
Figure 13. Trends in Highway Vehicle Use, 1980-1995
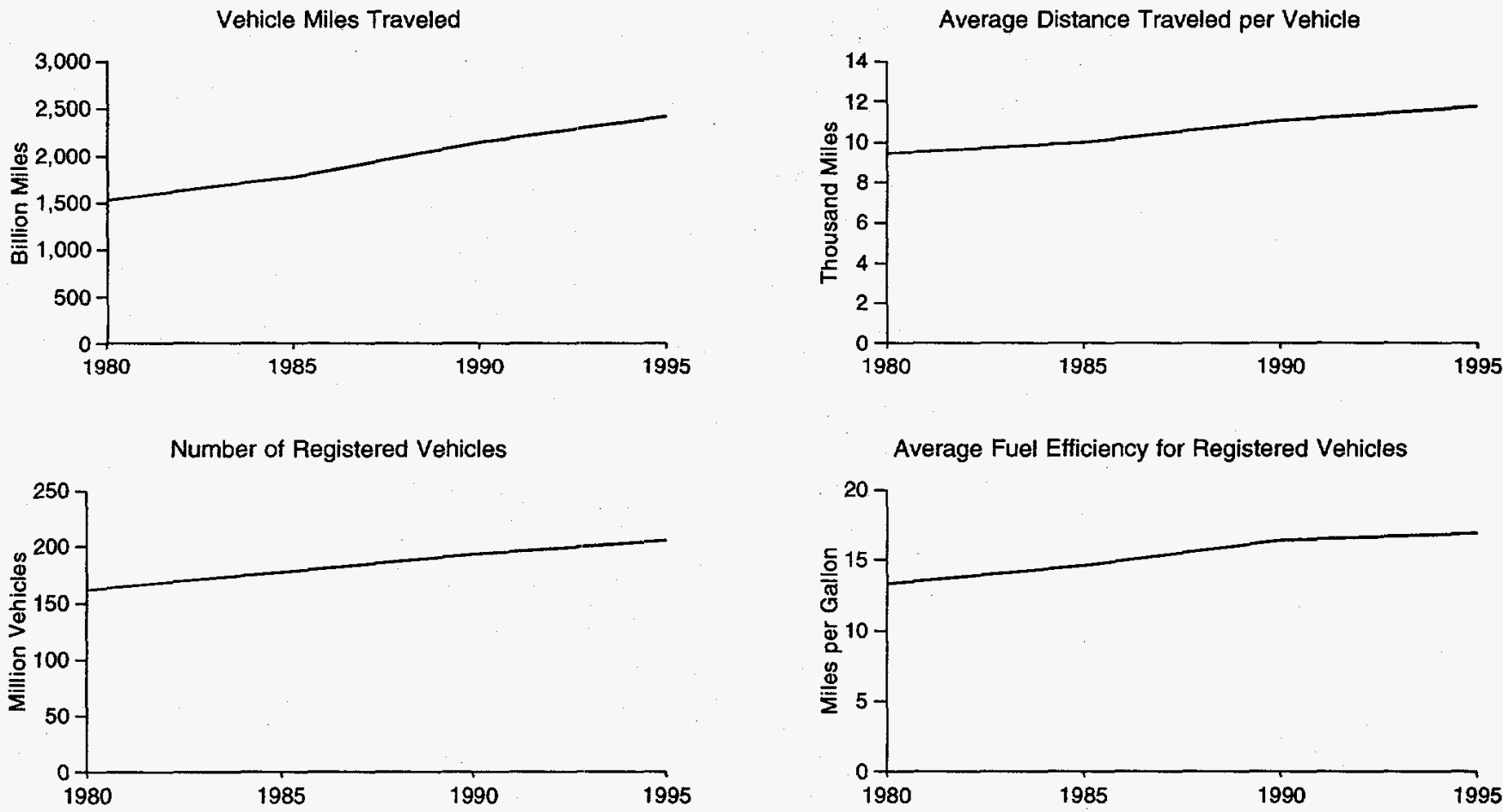

Source: U.S. Department of Transportation, Bureau of Transportation Statistics, National Transportation Statistics 1995, DOT-VNTSC-BTS-96-4 (Washington, DC, December 1996).

and Quad/Graphics, Inc., a printing company. Detailed information was provided for 40 (80 percent) of the projects on the long form (Form EIA-1605). (See Appendix A for a description of the reporting format.) Summary data for the remaining 10 projects were reported on the short form (Form EIA-1605EZ). Thirty-three (66 percent) of the projects reported in 1996 were affiliated with either Climate Challenge or Climate Wise.

The projects reported fell into three broad categories:

- Alternative fuel use ( 25 projects or 50 percent)

- Travel reduction (19 projects or 38 percent)

- Vehicle efficiency improvements (6 projects or 12 percent).

The majority ( 88 percent) of the projects involved passenger travel. For the 6 projects involving freight transportation, emissions reductions were achieved by reducing fuel consumption through improving vehicle efficiency ( 5 projects) or reducing travel ( 1 project).

The primary effect of the transportation projects reported was to reduce emissions of carbon dioxide, although reductions in emissions of nitrous oxide or methane were also reported for four projects. For 5 of the 50 transportation projects reported, emissions reductions were not estimated. The total reduction in carbon di- oxide emissions reported for 1995 for the remaining 45 transportation projects was 86,584 metric tons, almost 4 times the 22,146 metric tons reported last year for 1994 (Table 5). The increase between 1994 and 1995 was principally in efficient vehicle projects. The emissions reductions reported for these projects rose from 6,729 metric tons to 54,275 metric tons, primarily as a result of three new projects involving the operation of lightweight aluminum coal cars, accounting for over half of the total 1995 carbon dioxide emissions reduction for transportation projects (see box on page 31). Emissions reductions reported for travel reduction projects also increased by an impressive amount, from 594 metric tons in 1994 to 19,903 metric tons in 1995.

The average size of the reported carbon dioxide emissions reductions for transportation projects reported this year increased significantly over the previous year. The average reduction for 1995 was 1,924 metric tons, compared with 728 metric tons reported last year for 1994. Nevertheless, most reported transportation projects are still modest in size. Of those projects for which estimates were developed, 33 (73 percent) reported carbon dioxide emissions reductions of less than 1,000 metric tons in 1995. In 1995, efficient vehicle projects tended to be the largest projects, followed in order by travel reduction and alternative fuels projects (Figure 14). 
Table 5. Number of Projects and Carbon Dioxide Emissions Reductions for Transportation Projects by Project Type, Data Years 1994 and 1995

\begin{tabular}{|c|c|c|c|c|}
\hline \multirow[b]{2}{*}{ Project Type } & \multicolumn{2}{|c|}{ Number of Projects } & \multicolumn{2}{|c|}{$\begin{array}{l}\text { Emissions Reductions } \\
\text { (Metric Tons) }\end{array}$} \\
\hline & 1994 & 1995 & 1994 & 1995 \\
\hline Vehicle Efficiency & 2 & 6 & 6,729 & 54,277 \\
\hline Travel Reduction. & 9 & 19 & 594 & 19,903 \\
\hline Alternative Fuels & 22 & 25 & 14,823 & 12,403 \\
\hline Total $\ldots \ldots \ldots$ & 33 & 50 & 22,146 & 86,584 \\
\hline
\end{tabular}

Note: Totals may not equal sum of components due to independent rounding.

Source: Energy Information Administration, Forms EIA-1605 and EIA-1605EZ, "Voluntary Reporting of Greenhouse Gases."

\section{Figure 14. Transportation Sector Carbon Emissions Reduction Projects by Project Size and Type, 1995}

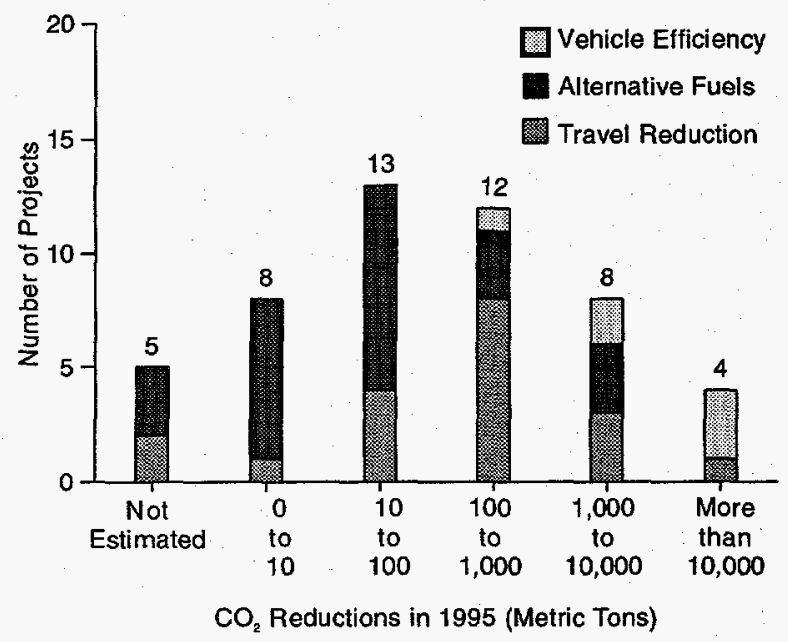

Source: Energy Information Administration, Forms EIA-1605 and EIA-1605EZ, "Voluntary Reporting of Greenhouse Gases."

There was a significant difference in the magnitude of emissions reductions reported for projects involving passenger and freight transportation. The six projects involving freight transportation accounted for 75 percent of the carbon dioxide emissions reductions reported for 1995. On average, freight transportation projects reduced emissions by more than 10,000 metric tons, nearly 20 times the average reduction achieved for measures involving passenger travel.

The level of activity necessary for passenger travel projects to reduce emissions by more than 100 metric tons is substantial. For example, to achieve a reduction in carbon dioxide emissions of 109 metric tons in 1995, Cinergy ran a fleet of 105 vehicles on compressed natural gas or propane instead of gasoline. General Public Utilities reduced vehicle travel by 885,805 miles to reduce emissions by 356 metric tons. On the other

\section{UNICOM's Aluminum Coal Cars Save Fuel}

In order to meet sulfur dioxide emissions reductions mandated by the Clean Air Act, UNICOM (formerly Commonwealth Edison Company) has been using low-sulfur coal since the 1970s. The coal is transported to UNICOM's power plants in Illinois by train from the Powder River Basin in Wyoming and Montana. Although the environmental benefits in acid rain reduction are significant, more energy is used for transporting the coal. UNICOM purchased lightweight aluminum coal cars to reduce the energy requirement.

Weighing in at 43,000 pounds each, the aluminum coal cars are 28 percent lighter than the 60,000pound steel cars they replaced. Lighter coal cars provide fuel savings on both legs of the 1,200-mile journey between Illinois and Wyoming or Montana. UNICOM operates 26 train sets, each of which makes 3.5 trips per month, for a total of 1,092 round trips per year. UNICOM estimates that the aluminum train sets save 1,533 gallons of diesel fuel per round trip. Therefore, in 1995, UNICOM saved $1,674,036$ gallons of fuel and avoided emissions of nearly 17,000 metric tons of carbon dioxide.

hand, many of these projects have wide applicability and could substantially reduce national carbon dioxide emissions if they were duplicated by companies throughout the industrial and commercial sectors.

\section{Using Alternative Fuels}

The alternative fuel vehicle projects reported involve the use of natural gas, electricity, propane, M-85 (a blend of 85 percent methanol and 15 percent gasoline), and ethanol (in a blend with gasoline). At least 97 percent of the reductions associated with altemative fuels 
were attributed to vehicles using natural gas, which was used in 16 of the 25 alternative transportation fuel projects reported and was the only alternative fuel used in 13 projects. Eleven projects involved the operation of electric vehicles. Nine were exclusively electric vehicle projects. The emissions reductions reported for electric vehicle projects in 1995 were relatively small (about 1 percent of the total for alternative fuel vehicles). Five alternative fuel vehicle projects also included infrastructure improvements associated with deployment of refueling stations for natural gas vehicles.

Three projects were oriented toward research and development. The Southern Company conducted or sponsored a range of research and development activities, including participation in the United States Advanced Battery Consortium, the Electric Power Research Institute's Electric Transportation Business Unit, and the Electric Vehicle Research Network. Public Utility District No. 1 of Snohomish County reported its sponsorship of an annual battery- and solar-powered boat race and an electric car race, the latter a new project in 1995.

\section{Reducing Vehicle Travel}

Travel reduction accounted for 22 percent of the total reduction in carbon dioxide emissions reported for transportation projects for 1995, up from 3 percent last year. Of the 17 demand reduction projects reported, 13 involved employee commute reduction or company vehicle use reduction. These projects included carpooling, increased use of mass transit, compressed work weeks, and subscription bus service. The largest demand reduction project, reported by Quad/Graphics (see the box below), involved ensuring that delivery vehicles were always full on return trips from delivering printed materials to customers. This project reduced carbon dioxide emissions by 12,078 metric tons in 1995, representing 65 percent of the total for reported travel reduction projects.

Two utilities reported on efforts to reduce vehicle miles driven by corporate vehicles. General Public Utilities Corporation implemented a videoconferencing system in 1991 that reduced employee travel by nearly 1.5 million miles between 1991 and 1995. For 1995, GPU indicated an annual savings of over 500,000 miles of employee travel. Public Utility District No. 1 of Snohomish County continued a pilot program in which bicycles are used by meter readers on suitable routes (emissions reductions were not estimated).

Two service efficiency improvement projects were also reported this year. Texas Utilities Electric Company

\section{Quad/Graphics Finds Four Ways To Reduce Demand}

Industrial and commercial companies consume much of the petroleum fuel used in the transportation sector either directly, for hauling raw materials and products, or indirectly, for employee commuting. Quad/ Graphics, Inc., a Climate Wise partner, is a printing company based in Wisconsin that has found four ways to reduce its own and its employees' demand for transportation services. The activities could easily be accomplished by other companies, and the relatively modest reductions achieved by the individual projects could be multiplied considerably.

The activities reported by Quad/Graphics and the associated carbon dioxide emissions reductions for 1995 were as follows:

- Duplainville Return Load Project (12,078 metric tons). Quad/Graphics ensures that trucks delivering finished printed products from its Duplainville plant do not return to the plant empty, but are used to haul supplies and raw materials. Quad/ Graphics estimates that this program saves $8 \mathrm{mil}-$ lion vehicle miles per year.
- 12-Hour Shift (2,844 metric tons). Quad/Graphics changed from three 8-hour shifts to two 12-hour shifts, which means that its employees work fewer days per year, reducing commuting trips and associated emissions. The employees added to the 12-hour shift since 1991 drove an estimated 20 million fewer miles in 1995.

- West Allis Plant Brownfield Site (1,550 metric tons). Needing a new facility, Quad/Graphics redeveloped an existing structure in West Allis, Wisconsin, instead of developing a greenfield site. A benefit of the West Allis site is that it is closer to town and workers' homes than was the greenfield site considered, with estimated savings of 3.5 million vehicle miles traveled in 1995.

- New Mass Transit Routes (1,887 metric tons). Quad/Graphics entered into a joint venture bus program with Milwaukee County Transit System (MCTS) in 1995. MCTS now provides service to the Pewaukee and Sussex plants twice daily to serve both shifts of workers, reducing the number of employee vehicle round trips by 23,185 and saving more than 20,000 gallons of gasoline. 
reported that use of fleet vehicles has been reduced through more efficient dispatching (including modifying service routes to put workers closer to work areas) and corporate downsizing. Duquesne Light Company has also reduced the size of its vehicle fleet and has achieved a 21-percent reduction in gasoline consumption since the effort was initiated in 1993.

\section{Improving Vehicle Efficiency}

Six projects involving the operation of more efficient vehicles were reported, five of which claimed relatively large emissions reductions (more than 1,000 metric tons) in 1995. The Tennessee Valley Authority has increased the fuel efficiency of its fleet vehicles since 1991, with cumulative savings in carbon dioxide emissions of more than 10,000 metric tons. Four Midwestern utilities reported the utilization of aluminum railroad cars to transport coal to their plants. UNICOM (formerly Commonwealth Edison Company) reduced 1995 carbon dioxide emissions by nearly 17,000 metric tons (see box on page 31). Substantial reductions were achieved by three other utilities using aluminum coal cars: Kansas City Power \& Light (15,786 metric tons), Western Resources, Inc. (14,713 metric tons), and Union Electric Company (5,330 metric tons). The smallest efficient vehicle project was an investment by Central Louisiana Electric Company (CLECO) in a company that developed and commercialized a device for monitoring and adjusting tire pressure on trucks to achieve optimal fuel efficiency. CLECO reported carbon dioxide emissions reductions of 303 metric tons for its 5-percent share of the project. The entire project reduced carbon dioxide emissions by more than 6,000 metric tons.

\section{Federal Voluntary Programs for the Transportation Sector}

The President's Climate Change Action Plan did not involve establishing participatory voluntary programs specifically for reducing greenhouse gas emissions in the transportation sector; however, participants in voluntary programs such as Climate Challenge and Climate Wise have made commitments involving, and are conducting, transportation projects. Government initiatives that affect motor vehicles and have the potential to reduce greenhouse gas emissions are regulatory in nature, with the primary objective of reducing emissions of the "criteria pollutants" that cause urban air pollution. Many of the measures that are being implemented in response to these regulations, particu- larly those aimed at reducing vehicle use (increased mass transit use, carpooling, and telecommuting) and those increasing vehicle fuel efficiency, will also reduce emissions of greenhouse gases. On the other hand, measures designed specifically to reduce the emissions of criteria pollutants often have ambiguous consequences for greenhouse gas emissions, particularly when fuel cycle effects are considered. Such measures include onboard pollution control equipment, fuel reformulation, and switching to alternative fuels.

\section{Reporting Issues}

Many reporting issues for transportation projects concern the proper accounting of fuel cycle emissions. One of the problems is making the distinction between direct and indirect emissions. For most reporters, direct emissions are those that result from the combustion of fuels in vehicles. Indirect emissions, which occur upstream of the vehicles, include emissions associated with such activities as exploration, production, transportation, and refining in the case of petroleum fuels.

Reporting reductions of direct emissions is relatively simple for projects that reduce fuel consumption through efficiency enhancement or travel reductions. Emissions coefficients are provided in an appendix to the instructions for Forms EIA-1605 and EIA-1605EZ. Estimating only direct emissions reductions for such projects is considered acceptable by the Voluntary Reporting Program, because it provides both accurate and conservative estimates of reductions achieved. (The accuracy of upstream, indirect emissions reduction estimates is more uncertain. Furthermore, since upstream reductions are proportional to both direct reduction achieved and fuel saved, omitting these values makes little difference in the qualitative information included.)

For projects that involve fuel switching, full fuel cycle effects are more important, because differences in upstream emissions associated with different fuels can be significant. Reporters had difficulty evaluating such projects because of the unavailability of suitable emissions coefficients. The fuel cycle emissions coefficients for transportation fuels given in the program's guidelines $^{32}$ do not distinguish between vehicle (direct) and nonvehicle (indirect) emissions for reporters interested in conducting fuel cycle analyses of their projects. EIA recently published fuel cycle emissions coefficients for gasoline, methanol, ethanol, compressed natural gas, and liquefied natural gas that separate vehicle and nonvehicle emissions (Table 6).

\footnotetext{
${ }^{32}$ U.S. Department of Energy, Sector-Specific Issues and Reporting Methodologies Supporting the General Guidelines for the Voluntary Reporting of Greenhouse Gases under Section 1605(b) of the Energy Policy Act of 1992, Volume II, DOE/PO-0028 (Washington, DC, October 1994), pp. 4.16-4.23.
} 
Table 6. Fuel Cycle Carbon Dioxide Emissions

(Grams per Vehicle Mile Traveled)

\begin{tabular}{|c|c|c|c|c|c|c|c|c|c|}
\hline \multirow[b]{2}{*}{ Fuel } & \multicolumn{3}{|c|}{ Vehicle } & \multicolumn{3}{|c|}{ Other Fuel Cycle } & \multicolumn{3}{|c|}{ Total } \\
\hline & $\mathrm{CO}_{2}$ & $\mathrm{CH}_{4}$ & $\mathrm{~N}_{2} \mathrm{O}$ & $\mathrm{CO}_{2}$ & $\mathrm{CH}_{4}$ & $\mathrm{~N}_{2} \mathrm{O}$ & $\mathrm{CO}_{2}$ & $\mathrm{CH}_{4}$ & $\mathrm{~N}_{2} \mathrm{O}$ \\
\hline Gasoline & 272.4 & 0.080 & 0.070 & 74.9 & 0.269 & 0.004 & 347.3 & 0.349 & 0.074 \\
\hline Methanol from Natural Gas & 270.4 & 0.080 & 0.070 & 112.7 & 0.467 & 0.005 & 383.1 & 0.547 & 0.075 \\
\hline Ethanol from Corn ....... & 301.1 & 0.080 & 0.070 & 24.4 & 0.541 & 0.341 & 325.5 & 0.647 & 0.411 \\
\hline Compressed Natural Gas & 204.7 & 0.900 & 0.070 & 43.5 & 0.559 & 0.001 & 248.2 & 1.459 & 0.071 \\
\hline LPG from Oil and Gas . & 235.4 & 0.080 & 0.070 & 28.1 & 0.190 & 0.001 & 263.5 & 0.270 & 0.071 \\
\hline
\end{tabular}

$L P G=$ liquefied petroleum gases.

Source: Energy Information Administration, Alternatives to Traditional Transportation Fuels 1994, Volume 2, "Greenhouse Gas Emissions," DOE/EIA-0508(94/2) (Washington, DC, August 1996), p. 16.

For electric vehicles, it is particularly important to evaluate emissions impacts upstream, where virtually all the emissions occur. Analysis of these projects presents the most difficulty, however, since reporters do not typically meter the electricity used to recharge vehicle batteries. While some information on the electricity consumption of electric vehicles is available, it does not always reflect the supply losses associated with battery operation, recharging, and transmission that determine how much electricity must be generated to fuel the vehicle (Table 7). In addition, the applicability of this information to specific projects is questionable, given the ongoing advances in both electric vehicle and battery technology. Furthermore, once electricity consumption has been estimated, determining the emissions consequences presents more than the usual difficulties. Using average system- or State-level

Table 7. Electricity Supply Requirements for Recent Electric Vehicle Models (Kilowatthours per Mile)

\begin{tabular}{c|c|c}
\hline \multirow{2}{*}{ Model } & \multicolumn{2}{c}{ Requirement } \\
\cline { 2 - 3 } & Vehicle $^{\mathrm{a}}$ & Total $^{\mathrm{b}}$ \\
\hline GM Impact $\ldots \ldots \ldots \ldots \ldots \ldots$ & 0.185 & 0.305 \\
Cocconi Honda CRX $\ldots \ldots \ldots$ & 0.166 & 0.273 \\
BMW E-1 $\ldots \ldots \ldots \ldots$ & 0.204 & 0.336 \\
Chrysler Van $\ldots \ldots \ldots \ldots \ldots$ & 0.483 & 0.785 \\
Ford Ecostar $\ldots \ldots \ldots \ldots \ldots$ & 0.302 & 0.497 \\
Honda CUV4 $\ldots \ldots \ldots \ldots \ldots$ & 0.249 & 0.410 \\
\hline
\end{tabular}

${ }^{a}$ Based on city cycle test procedure.

${ }^{b}$ Reflects combined battery/charging efficiency of 65 percent and transmission losses of 7 percent.

Sources: Vehicle Consumption: U.S. Congress, Office of Technology Assessment, Advanced Automotive Technology: Visions of a Super-Efficient Family Car, OTA-ETI-638 (Washington, DC, September 1995). Battery and Charging Efficiencies: M.A. DeLuchi, Emissions of Greenhouse Gases from the Use of Transportation Fuels and Electricity, Volume 2, ANLESD/TM-22 (Chicago, IL: Argonne National Laboratory, November 1993), Table B.1. emissions coefficients may not be appropriate because of time-of-day considerations. Electric vehicles are often driven during the day and recharged overnight. This pattern would result in the consumption of primarily baseload power, which would result in a wide range of upstream emissions, depending on the region of the country and the specific generator or power pool providing the electricity. Upstream emissions would be

\section{Figure 15. Comparison of Fuel Cycle Carbon Dioxide Emissions for Electric and Gasoline Vehicles}

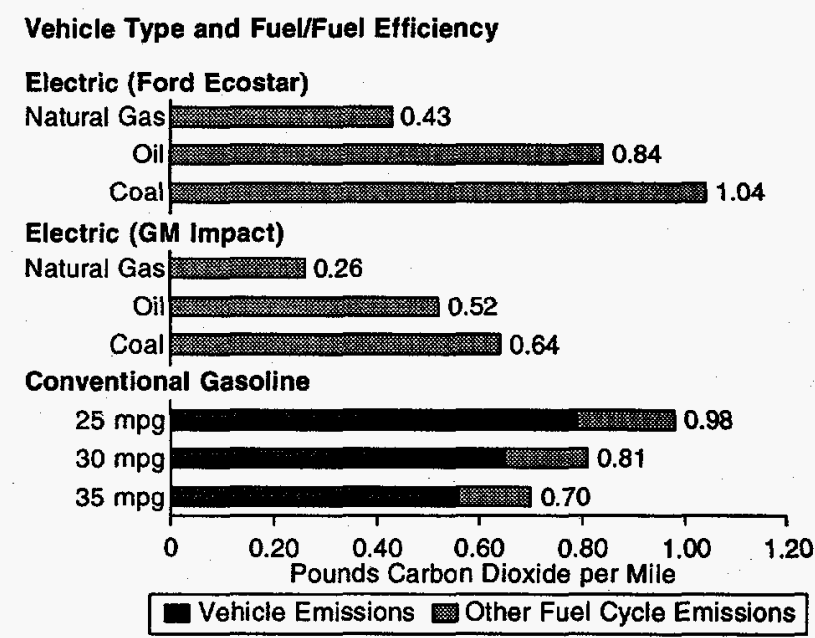

Notes: Electricity requirements to operate the electric vehicles are 0.497 and 0.305 kilowatthours per mile generated at source for the Ford Ecostar and GM impact, respectively. Assumed generation technologies are natural gas/combined cycle, oil/steam, and coal/ pulverized with wet flue gas desulfurization.

Sources: Electric Vehicle Electricity Consumption: U.S. Congress, Office of Technology Assessment, Advanced Automotive Technology: Visions of a Super-Efficient Family Car, OTA-ETI-638 (Washington, DC, September 1995). Carbon Dioxide Emissions: U.S. Department of Energy, Sector-Specific Issues and Reporting Methodologies Supporting the General Guidelines for the Voluntary Reporting of Greenhouse Gases under Section 1605(b) of the Energy Policy Act of 1992, Volume I, DOE/PO-0028 (Washington, DC, October 1994), Table 1.3. 
higher if coal, rather than natural gas or nonfossil fuels (nuclear, hydroelectric, wind, and other renewable sources), provided the bulk of the electricity.

Figure 15 compares the carbon dioxide emissions of gasoline vehicles (with fuel efficiencies of 25, 30, and 35 miles per gallon) with those of a Ford Ecostar (a twoseat light delivery vehicle) and a GM Impact (a twoseat passenger vehicle) operating on electricity from three different types of power plants: pulverized coal (with wet flue gas desulfurization), oil steam turbine, and natural gas combined cycle. Fuel efficiency for the electric vehicles is based on city driving. This analysis suggests that, under some circumstances, the use of electric vehicles may result in a net reduction in fuel cycle emissions. The magnitude of the reduction will depend on the fuel efficiency of the specific electric vehicle model, the efficiency of the conventional gasoline vehicle it replaces, and the source of the electricity used to recharge the electric vehicle's batteries. The use of larger or less efficient electric vehicles could even yield a net increase in emissions if the electricity used to recharge the batteries was generated from coal. 



\section{Carbon Sequestration}

\section{Background}

Carbon sequestration plays an important role in reducing carbon dioxide in the atmosphere. Green plants remove (sequester) carbon from the atmosphere through photosynthesis, whereby they extract carbon dioxide from the air, separate the carbon atom from the oxygen atoms, return oxygen to the atmosphere, and use the carbon to make biomass in the form of roots, stems, and foliage.

Every year in the United States and throughout the world a very large amount of carbon dioxide- on the order of 100 billion metric tons-is sequestered in biomass. ${ }^{33}$ At the same time, carbon is released to the atmosphere from vegetative respiration, combustion of wood as fuel, degradation of manufactured wood products, and the natural decay of expired vegetation. The net numerical difference, or flux, between carbon sequestration and release can be viewed as a measure of the relative contribution of biomass to the carbon cycle. World flux is difficult to measure, but it is thought to be a net "sink" of carbon dioxide.

Facts about the carbon content and sequestration potential of trees can give a sense of the importance of forests in offsetting human-produced carbon emissions. On average, trees are approximately 25 percent carbon by weight (live trees are approximately 50 percent water by weight, and oven-dried wood is approximately 50 percent carbon by weight). ${ }^{34}$ The amount of carbon a plant can sequester depends on a number of variables, including species and age, but can be quite large. For example, one large sugar maple tree is capable of removing more than 450 pounds of carbon dioxide from the atmosphere in a year. At that rate, preserving 25 trees per operating automobile in the United States would offset all U.S. automobile-related carbon dioxide emissions. ${ }^{35}$

Carbon sequestration on a national scale is substantial; the USDA Forest Service estimates that in the United States, all forests combined sequestered a net of approximately 281 million metric tons of carbon per year from 1952 to 1992 . This amount offset approximately 25 percent of U.S. emissions of carbon during that period. ${ }^{36}$

\section{Projects Reported}

A total of 62 entities reported forestry-related carbon sequestration or emissions reduction projects, a 155percent increase from the previous reporting cycle. The reporters included 58 electric utilities, 2 forestry organizations, a university, and a real estate company. A total of 199 carbon sequestration projects were reported, ${ }^{37}$ an increase of 255 percent from last year. Forestry projects were the third most popular type of project reported (after electricity supply and energy end-use projects), accounting for 21 percent of all reported projects for 1995 . Forestry projects are also the fastest growing project type in terms of the number of new projects reported. Fifty-seven new forestry projects were initiated in 1995-up 46 percent from the number started in 1994.

On average, carbon sequestration projects tend to be somewhat smaller than other types of projects (such as electricity supply and energy end use) in terms of their

\footnotetext{
${ }^{33}$ Intergovernmental Panel on Climate Change, Greenhouse Gas Inventory Reference Manual, IPCC Guidelines for National Greenhouse Gas Inventories, Vol. 3 (Paris, France, 1995), p. 5.2.

${ }^{34}$ R.A. Birdsey, Carbon Storage and Accumulation in United States Forest Ecosystems, (Washington, DC: USDA Forest Service, 1992 ), p. 12.

${ }^{35}$ Number of automobiles in operation in 1993, automobile miles traveled, and average miles per gallon from Energy Information Administration, Annual Energy Review 1994, DOE/EIA-0384(94) (Washington, DC, July 1995), pp. 67, 69. Carbon dioxide emissions per gallon of motor gasoline from U.S. Department of Energy, Sector-Specific Issues and Reporting Methodologies Supporting the General Guidelines for the Voluntary Reporting of Greenhouse Gases Under Section 1605(b) of the Energy Policy Act of 1992, DOE/PO-0028 (Washington, DC, October 1994), Vol. 2, p. 4.19.

${ }^{36}$ R.A. Birdsey and L.S. Heath, "Carbon Changes in U.S. Forests," in L.A. Joyce (ed.), Productivity of America's Forests and Climate Change, General Technical Report RM-GTR-271 (Fort Collins, CO: USDA Forest Service, 1995).

${ }^{37}$ Twenty-one of these projects were actually portions of the same project reported by 20 different entities participating in the Rio Bravo Carbon Sequestration Pilot Project (see text box in this chapter). Each entity reported only its share of carbon sequestered by the project.
} 
impact on atmospheric carbon dioxide. ${ }^{38}$ Most forestry projects sequestered between 10 and 10,000 metric tons of carbon dioxide (Figure 16). Their relatively small size is due in part to the fact that a significant number of the reported projects were urban forestry projects, involving the planting of trees in urban and suburban areas. Urban forestry projects are typically much smaller than forestry projects undertaken in rural or wilderness areas. The latter projects can in some instances be quite large, as evidenced by the fact that five such projects each sequestered more than 100,000 metric tons of carbon dioxide each.

\section{Figure 16. Carbon Sequestration Projects by Project Size}

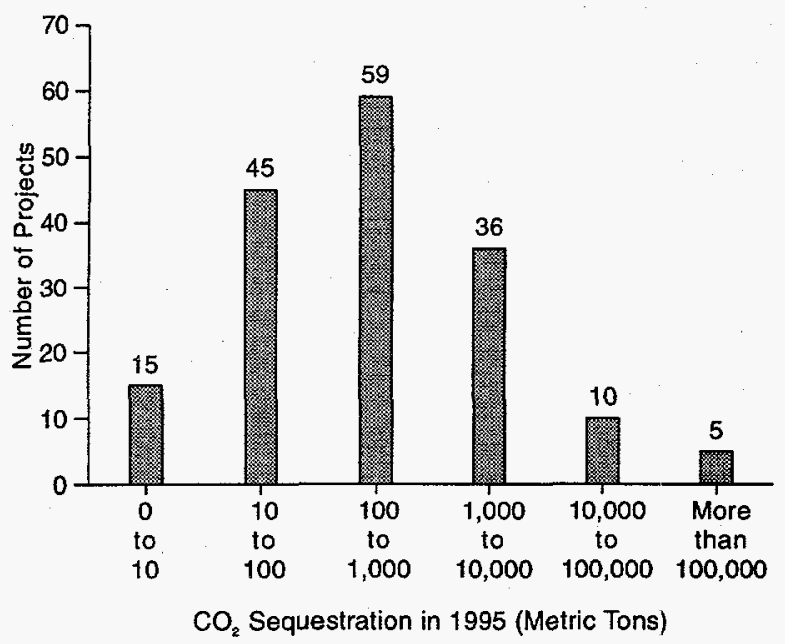

Source: Energy Information Administration, Forms EIA-1605 and EIA-1605EZ, "Voluntary Reporting of Greenhouse Gases."

The reported forestry projects were dispersed over a wide geographic area. Projects were reported in 40 States and 15 foreign countries. A total of 163 domestic and 36 international forestry projects were reported. Thirty-two of the domestic projects involved urban forestry.

\section{Domestic Forestry Projects}

Figure 17 shows the geographic distribution of the 133 domestic forestry projects reported (excluding urban forestry projects). Although they are scattered throughout the United States, the map indicates that projects are concentrated more heavily in and around the midAtlantic region (including Ohio, West Virginia, and Virginia) and the north central region (mainly Wisconsin, Minnesota, and Iowa). Many (68) of the reported domestic projects are reforestation projects, involving the planting of trees in areas that were recently cleared. Afforestation projects (involving the planting of trees in areas absent of trees in recent times) are less numerous but still fairly common; a total of 36 domestic afforestation projects were reported. Other project types reported in fewer numbers include forest preservation, improved forest management, and agroforestry.

Two organizations account for a disproportionate number of the domestic forestry projects reported. American Forests, a nonprofit forestry organization, reported on 62 different domestic forestry projects (as well as one urban forestry project). This was the largest number of projects reported by a single organization (see box on page 41). American Electric Power, Inc. (AEP), a large investor-owned utility, reported 36 domestic forestry projects and 1 foreign project. Taken together, American Forests and AEP account for nearly three-fourths of all of the domestic forestry projects reported for 1995.

Most of AEP's 36 domestic forestry projects were conducted on land owned by the utility in Ohio, West Virginia, and Virginia. The projects ranged in size from a 1.5-acre afforestation project that sequestered 4 metric tons of carbon dioxide in 1995 to a 1,265-acre improved forest management project that yielded 1,685 metric tons of sequestered carbon dioxide (Figure 18). AEP's total reported carbon dioxide sequestration for all projects more than doubled between 1992 and 1995 (Figure 19). The sharp upward trend reflects AEP's continuing efforts to develop new projects. Of the 36 projects reported, 15 were initiated in 1995.

The variety of measures undertaken by AEP can be seen in the following examples:

- The AEP-AEPSC-1995 project is an afforestation project. In March 1995, green ash, pin oak, and red oak were planted on idle land. The trees were planted as an Eagle Scout project, by Boy Scout Troop 166, on 1.5 acres at the rate of 700 seedlings per acre.

- AEP-APCo-1993 is another afforestation project, in which marginal cropland used for hay production was planted with loblolly pine. Eight acres were planted, at the rate of 625 seedlings per acre. The trees were planted in May 1993; an inspection conducted in March 1996 indicated that 80 percent of the seedlings had survived.

- AEP-APCo-1993FM is a forest management project, conducted in upland central hardwood stands ranging from 40 to 60 years in age. The stands were

\footnotetext{
${ }^{38}$ Reported estimates of carbon sequestration and emissions reductions may not be strictly comparable across projects. Participants employed a wide range of estimation methods in determining the effects of their projects. The database includes reported methodologies.
} 
Figure 17. U.S. Forestry Projects by State

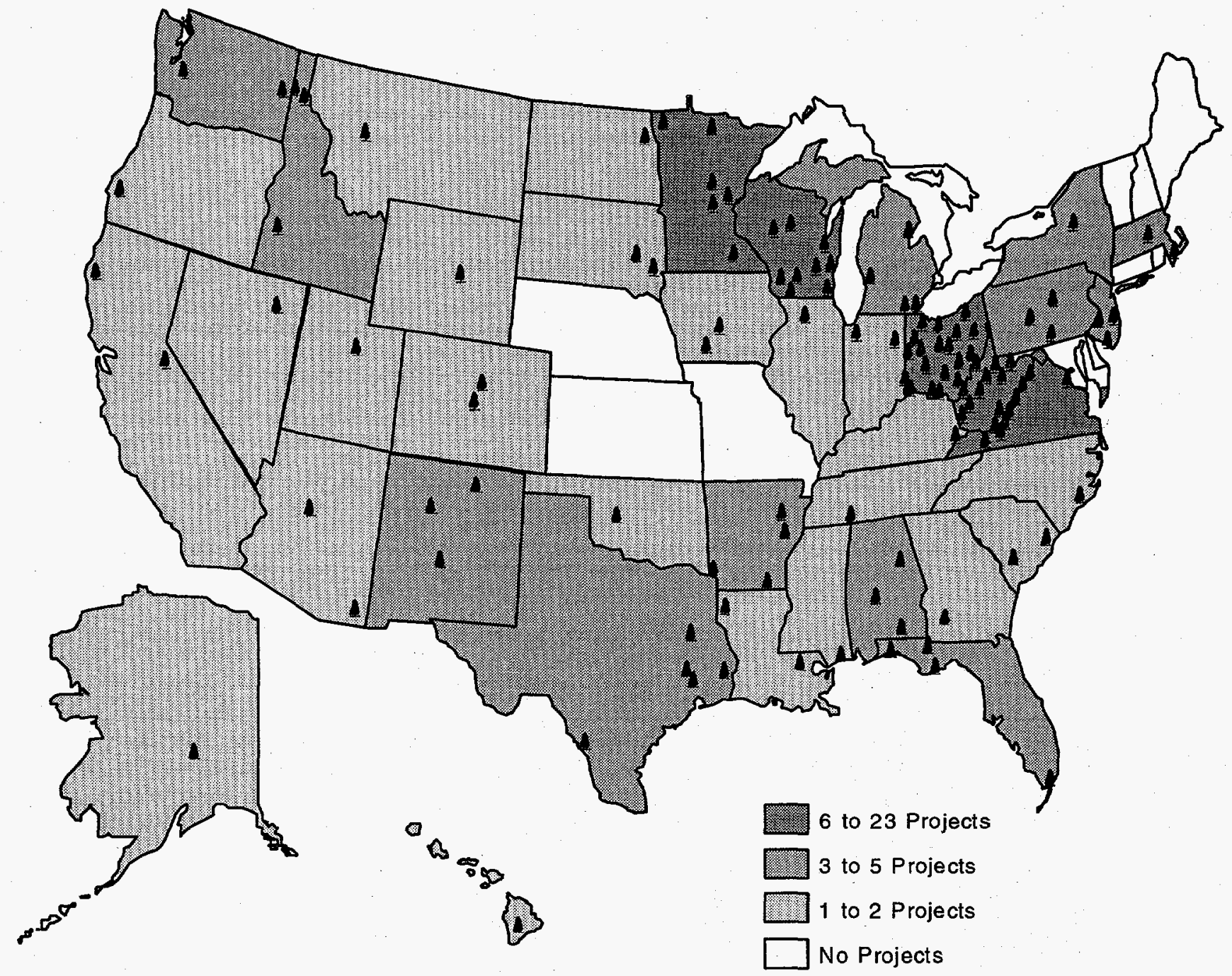

Source: Energy Information Administration, Forms EIA-1605 and EIA-1605EZ, "Voluntary Reporting of Greenhouse Gases."

selectively harvested to improve the growing space between trees by removing mature, over mature, and diseased trees. AEP estimates that 60 percent of the timber harvested is used in long-term wood products (e.g., furniture), where the carbon will remain sequestered for extended periods of time (e.g., 50 years).

- AEP-OPCo-1992P1 is an afforestation project, in which 129 acres of mined land reclaimed as pasture was planted with Austrian pine at the rate of 736 seedlings per acre. AEP reduced the sequestration estimate for this project by 50 percent from what they would otherwise have estimated, to reflect lower assumed tree growth productivities and survival rates for the reclaimed pasture.
In addition to the 15 new projects reported by AEP, a number of other organizations reported projects that were initiated in 1995. DTE Energy/Detroit Edison reported a forest management project involving a number of previously unmanaged woodlots consisting primarily of red oak, red maple, and ash. Because the sites were overstocked, it appeared that there had been very little increase in carbon sequestration in the years prior to the project. Detroit Edison conducted a commercial thin of the lots, which yielded approximately 2 million board feet of hardwood, for use mainly in durable goods such as furniture. Detroit Edison plans to manage the sites as sustainable yield forests, with selective harvesting on 5-year cycles. The project, which involves a total of 600 acres, sequestered an estimated 297 metric tons of carbon dioxide in 1995. 
Figure 18. American Electric Power's Dornestic Forestry Projects by Size

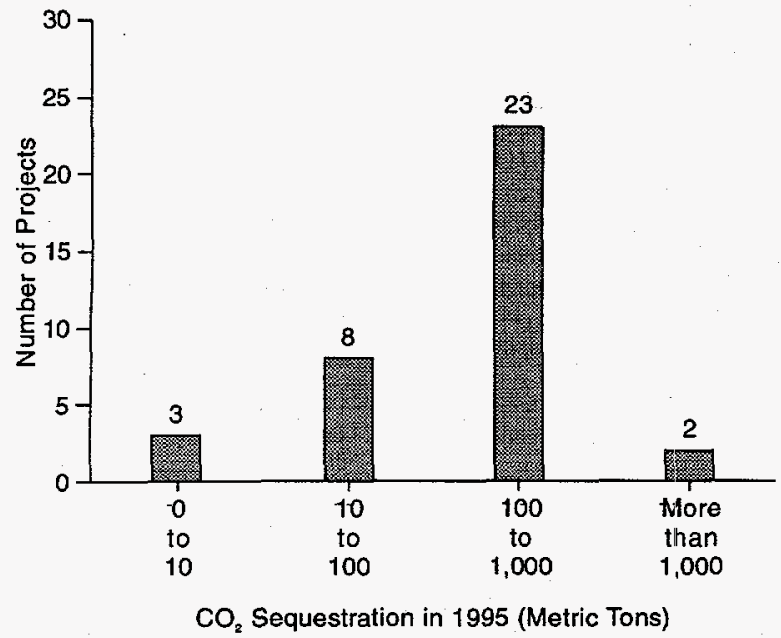

Source: Energy Information Administration, Form EIA-1605, "Voluntary Reporting of Greenhouse Gases."

Sunbelt Land and Mineral Company, a new reporter, reported an afforestation project at the Smith Place Tract in Dallas County, Alabama. The 163-acre tract was converted from pasture by the planting of loblolly pine seedlings. Additional activities undertaken to establish the stand and enhance growth included the elimination of the subsoil hardpan by row ripping, weed control, and the broadcast application of phosphate. Sunbelt Land and Mineral Company expects the pine plantation rotation to be 30 years, with forest management thinning in years 13 and 22 and the final cut in year 31. The tree survival rate after 1 year was 491 trees per acre. Estimated carbon dioxide sequestration was 298 metric tons in 1995.

Texas Utilities reported involvement in the Texas Reforestation Foundation, which is sponsored by the Texas Forest Service, commercial forestry companies, and private interests. Texas Utilities is the only electric utility member. Through the provision of funding and other arrangements, the foundation supports the planting of commercial species on suitable areas, mainly cut over or open lands. Texas Utilities contributes funds to the foundation on an annual basis. The amount of carbon dioxide sequestered by the Texas Reforestation Foundation's activities in 1995 was estimated at 980 metric tons.

Not all the new carbon sequestration projects were forestry projects. UNICOM (formerly Commonwealth Edison Company) reported the planting of Illinois Prairie Grasses on company properties. The amount of
Figure 19. Total Sequestration for American Electric Power's Domestic Forestry Projects, 1992-1995

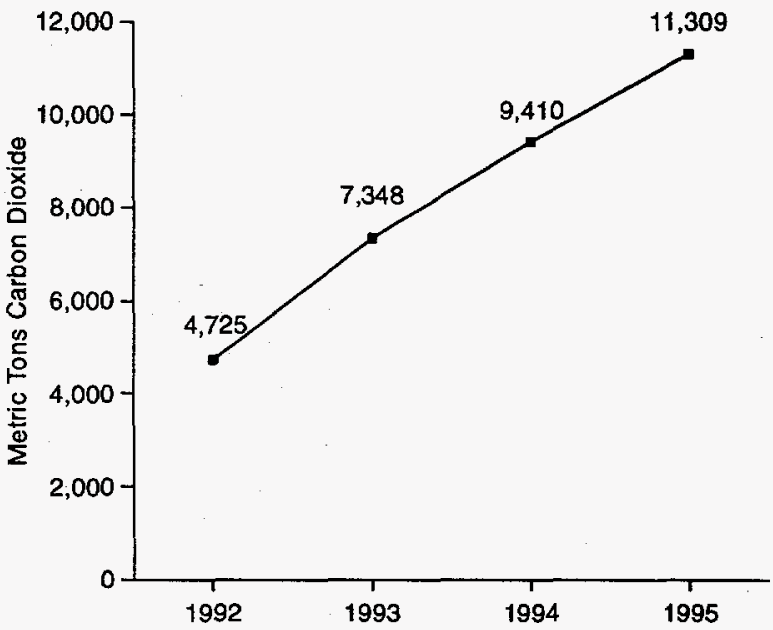

Source: Energy Information Administration, Form EIA-1605, "Voluntary Reporting of Greenhouse Gases."

carbon sequestered by prairie grasses is significantly greater than that sequestered by conventional turf grasses, because the former have much deeper root systems. UNICOM estimates that the prairie grasslands sequester 2,567 pounds of carbon dioxide per acre per year; hence, the total amount of carbon dioxide sequestered on the 300 acres planted by UNICOM was reported as 349 metric tons in 1995. UNICOM notes that other environmental benefits resulting from the project include reduced soil erosion and downstream flooding and elimination of the need for irrigation, fertilizers, pesticides, and herbicides.

\section{International Forestry Projects}

A total of 36 international projects were reported, in 15 different countries (Figure 20); however, 21 of these projects actually represent the shares reported by 20 different utilities involved in the Rio Bravo Carbon Sequestration Pilot Project in Belize. The box on page 43 provides more information on the project and the 20 participating reporters.

Thirteen of the 15 remaining projects were undertaken by a single organization: Trees for the Future, a nonprofit forestry organization. These projects are located in Africa (Cameroon, Ghana, Uganda, Kenya, and Chad), Asia (India, Nepal, Turkey, and the Philippines), and Central America (Guatemala, Belize, Honduras, and Panama). In 1995, Trees for the Future expanded plantings for 7 ongoing projects and initiated 6 new projects. More than 4 million trees were planted, which 


\section{Reporter Profile: American Forests}

American Forests, the oldest national conservation organization in the United State, was established in 1875 by a group of citizens concerned about the rapid deterioration of the Nation's forest resources. American Forests has sought to promote the protection and sustainable management of forests through programs in research, policy, education, and citizen action.

An important part of the organization's work in recent years has been to develop understanding of forests as part of the global climate change dynamic. American Forests has been involved in the development of science and technology to bring new information to the public discussion. It has also developed projects to reduce emissions through energy-saving urban forestry projects and carbon-sequestering rural projects, and has participated in the Federal Country Studies program to provide technical support to developing and transitional countries that are seeking to include forestry projects in their national efforts to mitigate global climate change. (Although the projects reported to EIA are domestic, American Forests also works through the U.S. Initiative on Joint Implementation to develop opportunities for investing in carbon offset projects in other countries.)

From a total of 12 projects in 12 States in 1992, American Forests' projects have expanded to 63 (including one urban forestry project) in 31 States as of 1995. American Forests estimates that the projects sequestered a total of 24,558 metric tons of carbon dioxide in 1995 , an average of nearly 400 metric tons per project.

The domestic forestry projects reported to EIA are part of the American Forests Global ReLeaf campaign, initiated in 1988. The Global ReLeaf Forests program-part of the organization's larger citizen action and education effort-supports the restoration of forest ecosystems across the United States that have been damaged by natural or human events. Global ReLeaf solicits project support from individuals and organizations to help improve the environmentlocally and globally - through tree planting. As of early 1997, the program had planted 5 million trees, representing one-fourth of the program's goal of 20 million by the year 2000 . Developing project support through organizations interested in sequestering carbon is a major strategy of attaining that goal. Examples of the Global ReLeaf projects reported to EIA include:

- The planting of a 25-acre tract in Pennsylvania's Allegheny National Forest with red oak seedlings, to replace trees lost to drought and gypsy moth defoliation. To protect the seedlings from the large deer population, each was planted with a tree shelter.

- The Big Woods Ecological Restoration Project in southeastern Minnesota, which was a joint effort involving the Minnesota Department of Natural Resources-Parks, the Minnesota Nature Conservancy, the Land Stewardship Project, the County Soil \& Water Conservation District, area colleges, public schools, private and public agencies and citizen groups, as well as American Forests. The project involved the planting of 8,000 red oak and 500 butternut seedlings on old fields. The project's goals included restoration of the canopy as well as the provision of educational opportunities and the enhancement of community involvement.

- The restoration of longleaf pine on the Sam Houston National Forest, San Jacinto Ranger District, Texas. The site is near the southwestern-most limit of the U.S. longleaf pine ecosystem, and it hosts a number of wildlife species that will benefit from the project, including quail and wild turkeys.

- The reforestation of a 60-acre site identified as an "Area of Critical Environmental Concern" near Casper, Wyoming. The site, which was damaged by the Little Red Creek Wildfire, is a winter roosting area for the American Bald Eagle.

- The planting of 17,000 seedlings on 43 acres to begin the restoration of a 1,000-acre site destroyed by Hurricane Andrew in Dade County, Florida. The site contained the last large expanse of South Florida slash pine in the southeastern part of the county. It could eventually accommodate 500,000 seedlings. exceeded the total number reported for previous years (1991 through 1994). Total estimated carbon sequestration for the 13 projects, which had increased from approximately 60,000 metric tons in 1992 to 105,000 metric tons in 1994, doubled in 1995 to 210,000 metric tons. 


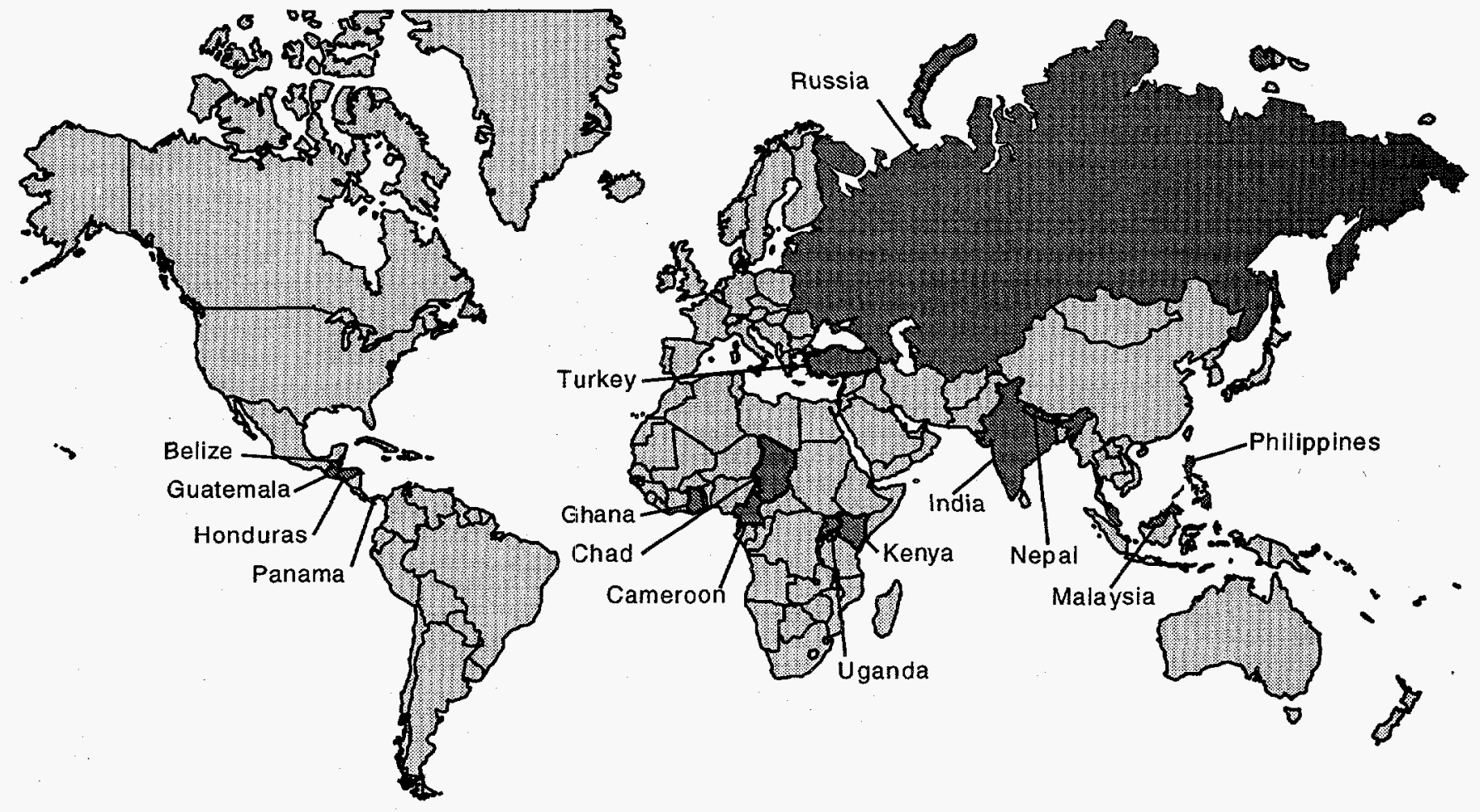

Source: Energy Information Administration, Forms EIA-1605 and EIA-1605EZ, "Voluntary Reporting of Greenhouse Gases."

Examples of the projects undertaken by Trees for the Future include:

- A project to provide training in agroforestry, reforestation, and silviculture management and to distribute seeds of fast-growing trees to communities in the Cortes Province of northern Honduras. As a result of logging, slash and burn agriculture, and cattle grazing, the uplands of northern Honduras have been almost entirely denuded of trees. The loss of upland forest has in turn led to flooding of the valleys and declining food production. Trees for the Future became involved in the region in response to a request from a local women's branch of International Friends, in the city of San Pedro Sula. The initial seed plantings, in August 1991, proved highly successful, thus convincing many additional communities to join the program. Since that time, seedbed nurseries have been established throughout Cortes Province, the program has expanded into the Santa Barbara and La Esperanza areas in cooperation with the Honduran Ecological Association, and a training center has been established in San Pedro Sula, with additional local extension trainers and technicians operating in the city of Puerto Cabezas and a number of smaller towns. New technologies are under development to expand the project's primary tree species (Leucena leucocephala) to coffee plantations. In addition to the carbon sequestration benefits of the project, local participants have benefitted from improved erosion control and use the leaves and wood for cattle forage, organic fertilizer, and fuel.

- A tree planting project near Mudaurai, India, which since 1991 has expanded to include two additional areas in India. Working with rotary clubs and other community organizations, Trees for the Future initially planted 5,000 leucena trees around Madurai. The success of this planting led to the planting of an additional 186,000 trees in the Madurai area, using seeds from the original 5,000 trees. The project was subsequently expanded to the areas of Uttar Pradesh, in the city of Vrindavan, and to the Bombay area. Vrindavan is a sacred city visited by hundreds of thousands of Hindu pilgrims each year. The Temple area was the initial planting site, selected so that pilgrims could see the enhancement provided by the trees. Since the initial planting, 435 hectares have been planted. The Vrindavan plantings have been conducted in cooperation with the Friends of Vrindavan, a U.S.-based organization. Finally, the Bombay-area activities, in cooperation with the RISED Foundation of Devashayam, the Amercy Foundation, and local rotary clubs, have reforested 450 hectares of barren land. More than 


\section{Project Profile: The Rio Bravo Carbon Sequestration Pilot Project}

The Rio Bravo Carbon Sequestration Pilot Project is being undertaken through a partnership of Wisconsin Electric, DTE Energy/Detroit Edison, Cinergy, Pacificorp, and UtiliTree Carbon Company (the "Financial Participants"). UtiliTree is a consortium of 40 electric utilities, and each contributed financial support to the Rio Bravo project. Also participating are The Nature Conservancy and a Belizean nongovernment organization, Programme for Belize. In addition to their financial role, the Financial Participants are closely involved in project design and implementation support. The project has been accepted by the U.S. Initiative on Joint Implementation.

The project is located in northwestern Belize, Central America, and centered on the eastern land parcels of the Rio Bravo Conservation and Management Area. The project has two components:

- Component A included the purchase and preservation of a 13,843 acre parcel of endangered forest threatened with deforestation and conversion to intensive row crop agriculture. The purchase of this parcel linked two forested Rio Bravo properties owned by Programme for Belize in the northwestern corner of Belize.

- Component B will establish a sustainable forestry management program on the entire Rio Bravo Conservation and Management Area, which includes Component $A$, as well as the other land parcels already held by Programme for Belize. Component B will implement improved forest management techniques and timber processing and marketing approaches. It is designed to optimize carbon sequestration in a 120,000-acre area.

Only Component A of the Rio Bravo project was reported for the 1995 reporting cycle. Component B will be reported in a subsequent reporting cycle.

The Rio Bravo project sequestered a total of 152,640 metric tons of carbon dioxide in 1995. The carbon sequestration estimate was based on actual measurements from 58 permanent plots in Component $A$ of the Rio Bravo project in 1996.

This project was reported by the 4 utility Financial Participants and by 16 of the utility participants in the UtiliTree Carbon Company: American Electric Power, Baltimore Gas \& Electric, Central Illinois Light Company, Duke Power Co., General Public Utilities Corp., Illinois Power Co., Kansas City Power \& Light, New England Electric System, Northern Indiana Public Service, Ohio Edison Co., Sierra Pacific Power Co., Tampa Electric Co., Tennessee Valley Authority, Texas Utilities Corp., Tucson Electric, and Western Resources. One of the Financial Participants (Cinergy Corp.) provided separate reports for its individual participation and its involvement through UtiliTree. As a result, the Voluntary Reporting Program received 21 separate reports on this project, although each reporter claimed only its share of the total carbon sequestration. The reports received covered 94 percent of the carbon sequestered by the project.
1 million trees have been planted in the three areas encompassed by the project.

- A land restoration and agroforestry project in and around Lake Chad, in Chad. The land around the lake is mainly desert, which has been sparingly grazed over many centuries. The lake is drying, due to evaporation and declining water aquifers in the surrounding uplands. Trees have been planted on hummocks in the lake itself to reduce evaporation, as well as on the surrounding uplands to control erosion and provide forage for grazing animals. The plantings consist of drought-resistant, fast-growing, multipurpose trees. The project is designed for sustainable production of fuel and forage; more recently, fruit trees and hardwood timber trees have been added to the stands.

\section{Urban Forestry Projects}

Urban forestry projects are unique, in that under some circumstances they can reduce energy consumption as well as sequester carbon. Shade trees planted near buildings reduce summer air conditioning requirements; in addition, trees can also act as windbreaks, reducing heating needs in the winter. A total of 32 urban forestry projects were reported for 1995 (Figure 21). Carbon sequestration estimates were provided for 31 of the 32 projects, but emissions reductions associated with energy savings were provided for only 5 projects. ${ }^{39}$ There are probably two main reasons for the absence of emissions reduction estimates. First, not all urban forestry projects involve the planting of shade trees near buildings. Urban forestry encompasses treeplanting in all urban and suburban settings, including

\footnotetext{
${ }^{39}$ Including one project for which sequestration effects were not reported.
} 
Figure 21. U.S. Urban Tree Planting Projects by State

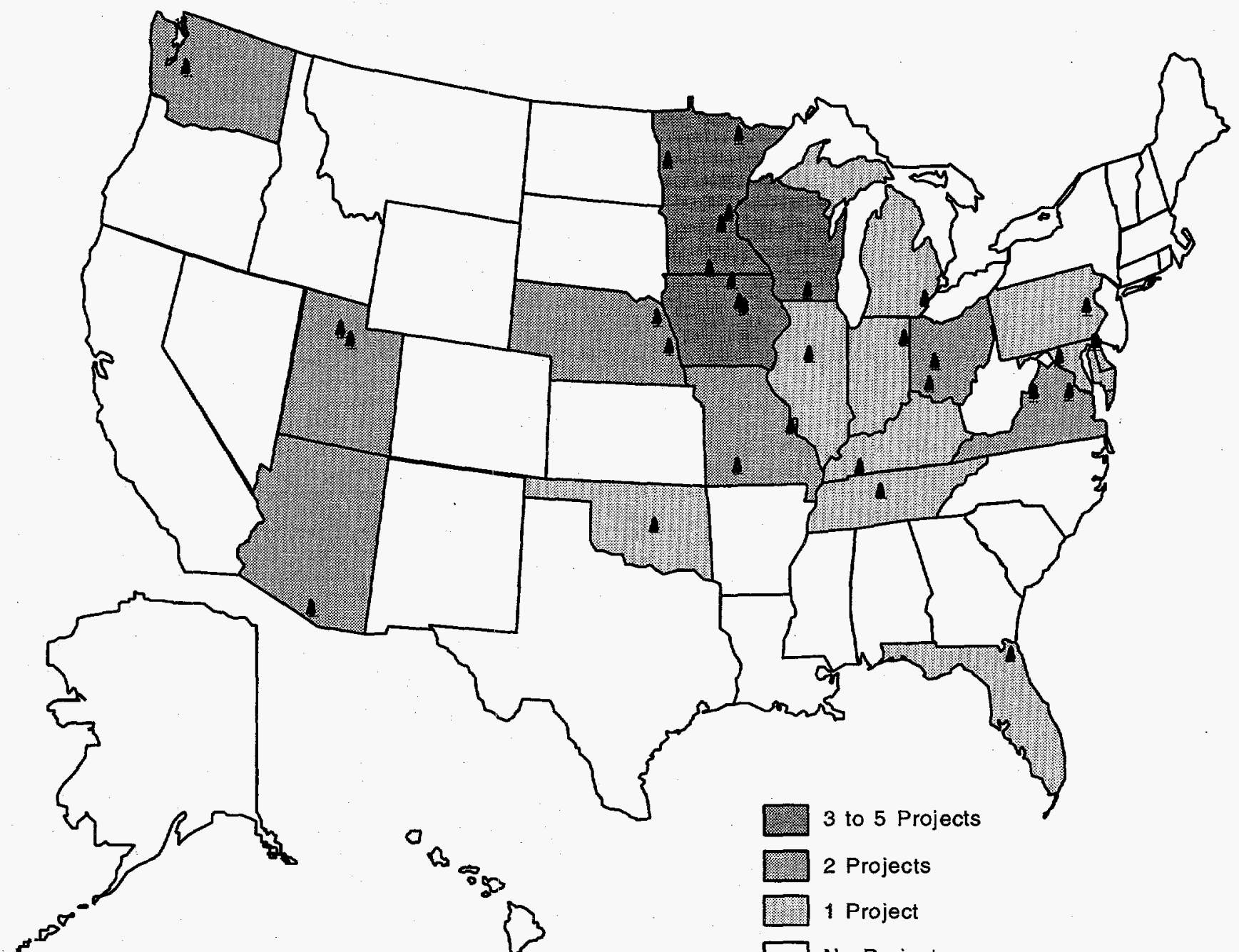

No Projects

Source: Energy Information Administration, Forms ElA-1605 and ElA-1605EZ, "Voluntary Reporting of Greenhouse Gases."

parks, utility rights of way, and city streets, as well as around buildings. Second, it is often difficult to estimate the energy savings resulting from urban forestry projects. Models have been developed for this purpose, but they are complex and not widely used.

American Forests was able to develop both sequestration and emissions reduction estimates for its urban forestry project at the Davis-Monthan Air Force Base in Arizona. The project, undertaken as part of DOE's Cool Communities program, involved the planting of 340 trees on a 64-home site at the base. The trees reduce ambient temperatures and decrease energy usage associated with air conditioning. American Forests estimated that the reduction in carbon dioxide emissions resulting from this project was significantly greater than the amount of carbon dioxide sequestered
(6.8 metric tons and 1.5 metric tons, respectively). This is typical of urban forestry projects undertaken to reduce energy consumption. The three other projects for which comparative data are available indicate that the emissions reductions range from about 3.5 to nearly 32 times the corresponding sequestration estimates.

The Davis-Monthan project was initiated in 1995. Other new projects initiated in 1995 include Bountiful City Light \& Power's tree replacement project, in which the utility offers its customers a replacement tree for each tree removed to clear transmission and distribution lines. If the affected customer does not wish to take the tree, it is offered to the City Parks Department, the School District, or a charitable organization for planting elsewhere in Bountiful. In 1995, 14 trees were planted as part of the project, including 4 silver maples, 3 
eastern redbuds, 3 cottonwoods, 2 mountain ashes, and 2 Norway maples. Total estimated sequestration for the project was 0.06 metric tons of carbon dioxide in 1995.

Central Illinois Light Company (CILCO) reported on its TreeLine USA Program, initiated in 1995 in cooperation with the cities of Peoria and Pekin. Under this project, CILCO donated $\$ 5,000$ to each city for the purchase and planting of deciduous trees on city property. A total of 121 deciduous hardwoods were planted in Peoria, and 64 were planted in Pekin, providing for the sequestration of an estimated 0.46 metric tons of carbon dioxide in 1995.

In addition to the above new projects, a number of new reporters reported on projects that were initiated before 1995. Tucson Electric Power Company (TEP), for example, reported on its Trees for Tucson program. The primary focus of this project is to reduce energy consumption for air conditioning by planting desertadapted shade trees (mainly mesquite) around homes and other buildings in TEP's service territory. Thus far, more than 11,000 trees have been distributed to residences, schools, community projects, and the DavisMonthan Air Force Base. The project sequestered an estimated 3 metric tons of carbon dioxide in 1995.

Another new reporter, Blue Earth Light \& Water, reported on its project to plant trees in various locations within the town of Blue Earth, Minnesota. This project sequestered an estimated 0.33 metric tons of carbon dioxide in 1995.

\section{Federal Voluntary Carbon Sequestration Programs}

More than half of the reported forestry projects were undertaken in part to fulfill commitments made under the Climate Challenge program. In addition, 10 percent were undertaken as part of the U.S. Initiative on Joint Implementation (USIJI). Established under the Climate Change Action Plan (CCAP), ${ }^{40}$ the USIJI is a pilot program that seeks to encourage foreign-based emissions reduction and carbon sequestration projects between U.S. and non-U.S. partners. Partners must submit a proposal to USIJI to receive approval of proposed projects; thus far, 24 projects have been approved, ${ }^{41}$ encompassing a wide variety of measures, including energy conservation in district heating systems, conversion of biomass waste to energy, wind power, and forestry projects. USIJI projects reported to EIA include the Rio Bravo Carbon Sequestration Pilot Project (see box on page 43); Oregon State University's RUSAFOR-SAP project, involving reforestation and afforestation of three sites in Russia; and New England Electric System Companies' Reduced Impact Logging Project, which involves the development and implementation of reduced-impact logging techniques on 1,400 hectares of commercial forest in Malaysia.

In addition to these USIJI projects, two urban forestry projects were reported as part of the Cool Communities Program. This program, sponsored by the U.S. Department of Energy, seeks to reduce energy consumption associated with air conditioning through the use of lighter wall and roof colors and the planting of shade trees around buildings. The program provides technical assistance and education in the implementation of these measures. The two Cool Communities projects were located in Arizona: American Forests' Urban Ecosystem Analysis project at the Davis-Monthan Air Force Base and Tucson Electric Power Company's Trees for Tucson program.

\section{Reporting Issues}

Some of the carbon removed from the atmosphere by plants becomes incorporated into structural elements of plants (e.g., roots, stems, foliage). The rest is consumed by the plant's metabolic processes (respiration), and the carbon is returned to the atmosphere as carbon dioxide. Likewise, when all or part of the plant dies and decays, much of the carbon is released to the atmosphere, and a portion is retained as soil organic matter. The effect of a forestry project on atmospheric levels of greenhouse gases is measured by net sequestration, the net quantity removed from the atmosphere in a given year.

Some guidance is available to assist reporters in estimating net sequestration, including that provided in the program's guidelines. ${ }^{42}$ This guidance typically focuses on net sequestration over a given period, usually until the forest reaches maturity. Annual net sequestration for an afforestation or reforestation project will vary considerably over this period. In the early years, net sequestration can be low or even negative. It generally peaks in the middle years and gradually tails off as the living biomass structures reach maximum size. At maturity, new growth sequestering carbon may. be balanced by mortality. Forests, if undisturbed, will

\footnotetext{
40President William J. Clinton, The Climate Change Action Plan (Washington, DC, October 1993), Appendix II.

41"Nine New USIJI Projects Approved," International Partnerships Report, Vol. 3, No. 1 (February 1997), p. 1.

${ }^{42}$ U.S. Department of Energy, Sector Specific Issues and Reporting Methodologies Supporting the General Guidelines for the Voluntary Reporting of Greenhouse Gases under Section 1605(b) of the Energy Policy Act of 1992, Vol. 2, Part 5 (Forestry Sector), DOE/PO-0028 (Washington, DC, October 1995).
} 
continue to be a net carbon sink indefinitely, as a portion of the carbon in the dead biomass ends up in the soil. Typically, the quantities reported represent the annual average sequestration over a specified time period, usually from planting until the forest reaches maturity.

Carbon in forests cannot be considered permanently sequestered, however. Perturbations, such as timber harvesting and fires, can rapidly reverse decades of sequestration, returning the carbon to the atmosphere. This represents an accounting challenge for any system of credits, allowances, or offsets designed to control greenhouse gases that mixes sequestration with emissions reductions. In contrast to the impermanence of sequestration, emissions reductions represent a permanent, irreversible debit from the amount of greenhouse gases in the atmosphere. To some degree, the problem can be overcome by a life-cycle approach to evaluating emissions that takes timber harvesting into account when average annual sequestration is estimated; however, unplanned events (forest fires) or any change in land use are problems for any greenhouse gas emissions accounting scheme.

Evaluating urban forestry projects presents reporters with the dual challenge of estimating carbon sequestration and emissions reductions resulting from energy savings. Most of the available guidance for estimating sequestration, aimed at estimating sequestration by the acre, is not applicable to urban forestry. As a remedy, EIA has developed a worksheet for this purpose (see box below).

The energy effects of urban forestry projects are even harder to estimate than the sequestration effects. Although models are available for this purpose, they are complex and require site-specific data, particularly on

\section{Reporting Issue: Ten Reporters Use Urban Forestry Guidance Document}

The Voluntary Reporting Program has released a guide designed to assist participants in determining the quantity of carbon sequestered by urban forestry projects. A total of 10 reporters used the guide in the preparation of their 1995 reports.

Calculating the carbon sequestration potential of urban trees can be a complex undertaking. It is necessary to account for differences in species type, which affect tree growth rates and sequestration potential. In addition, tree mortality, which differs by species type and over time, must be considered in determining the percentage of trees removed from the sequestration pool each year.

The guide, Method for Calculating Carbon Sequestration by Trees in Urban and Suburban Settings, was based on research by the Voluntary Reporting Program and findings from USDA Forest Service researcher David Nowak. Growth rate and mortality estimates for 100 tree species commonly planted in urban and suburban settings are included in the guide.

The guide contains the following components:

- Detailed instructions on all aspects of urban forestry carbon sequestration reporting under the Voluntary Reporting Program

- A look-up table containing species names, types, and growth rates of 100 common urban tree species
- A look-up table containing mortality rates ("survival factors") for different tree species

- Worksheets designed to walk a reporter through each step of the process.

The participants using the guide were Blue Earth Light and Water, Bountiful City Light and Power, Cedar Falls Utilities, Central Illinois Light Company, City Utilities of Springfield, Detroit Edison, Rappahannock Electric Cooperative, Seattle City Light, Shenandoah Valley Electric Cooperative, and Tucson Electric Power Company. The guide prepared by the Voluntary Reporting Program is by no means the only guide or even the best guide. It is simply a standardized tool that can be applied to a wide variety of locations and circumstances, with the intent of making the job of reporting carbon sequestration by urban forestry projects easier for participants in the program. Other participants employed their own calculation methodologies based on research from hired consultants, the USDA Forest Service, and other Federal and State government agencies.

Method for Calculating Carbon Sequestration by Trees in Urban and Suburban Settings is available to the public through the Voluntary Reporting Program's file transfer protocol (FTP) site at ftp://ftp.eia.doe.gov/pub/oiaf/ $1605 /$ cdrom (file name sequestr.pdf), ${ }^{*}$ by e-mailing a request to infoghg@eia.doe.gov, or by calling 1-800803-5182 or 202-586-0688.

*The software application Adobe Acrobat Reader is needed to open and print this file. This application is available free from Adobe at: http://www.adobe.com. 
climate, that are not readily available. Of the 32 urban forestry projects reported, only 4 explicitly estimated emissions reductions associated with the projects' energy effects. Two reporters (Waverly Light \& Power and Osage Municipal Utilities) used a stipulated factor of 132 kilowatthours saved per tree planted, developed by a consultant. To evaluate a project involving tree planting on home sites within an Air Force Base in Arizona,
American Forests used its own CITYgreen Urban Ecosystem Analysis software. PacifiCorp based its estimate of the energy savings and resulting emissions reductions of its Salt Lake City Urban Forestry Project on a spreadsheet model which assumes that annual cooling savings of 12 percent are achieved once a tree reaches maturity. 



\section{Projects To Reduce Methane Emissions}

\section{U.S. Methane Emissions in Perspective}

U.S. methane emissions totaled 30.9 million metric tons in 1995, the equivalent of 649 million metric tons of carbon dioxide considering the relative atmospheric warming effects of methane and carbon dioxide. ${ }^{43}$ Over a 100 -year time horizon, 1 ton of methane is estimated to have 21 times the warming effect of 1 ton of carbon dioxide. U.S. anthropogenic carbon dioxide emissions are about 170 times as large as methane emissions when measured by their full molecular weight, but when they are weighted by global warming potential (GWP), carbon dioxide emissions are only about 8 times as large as methane emissions (Table 8). (For a discussion of global warming potentials, see "What Are Greenhouse Gases" on page 6.)

While emissions of carbon dioxide rose by more than 5 percent between 1990 and 1995, emissions of methane declined by more than 2 percent. Because almost all carbon dioxide emissions ( 98 percent) can be attributed to fossil fuel consumption, changes in emissions levels are largely driven by economic growth, energy prices, and weather. Thus, during periods of steady or strong economic growth and stable or declining real energy prices, such as that which has been experienced in the United States since 1992, it is difficult to restrain the growth of carbon dioxide emissions.
In contrast, methane emissions are principally the result of either biological processes or unintended fugitive releases. Because methane can be used as an energy source, it can be recovered at some economic benefit. Additionally, methane releases from biological processes may represent system inefficiencies that can be modified by improved agricultural methods or more productive animal husbandry. Thus, trends in methane emissions are more easily separated from general economic trends than are trends in carbon dioxide emissions. Further, because a large share of methane emissions can be traced to a relatively small number of facilities, technological solutions and public policy may be more effectively focused on sources of methane emissions than on the millions of separate sources of carbon dioxide emissions in the United States.

\section{Projects Reported}

There were 58 methane reduction projects reported for 1995, an increase of nearly 35 percent over the number reported for $1994 .{ }^{44}$ Together, these 58 projects reduced methane emissions in 1995 by more than 1.1 million metric tons, more than 7 times the reduction of 150,000 metric tons reported for 1994 (Table 9). Nearly all reductions were reported as indirect; only a small portion $(8,269$ metric tons) were reported as reductions

Table 8. Estimated U.S. Emissions of Carbon Dioxide and Methane, 1990-1995

(Million Metric Tons)

\begin{tabular}{c|r|r|r|r|r|r}
\hline Gas & \multicolumn{1}{c|}{1990} & \multicolumn{1}{c|}{1991} & \multicolumn{1}{c}{1992} & \multicolumn{1}{c|}{1993} & \multicolumn{1}{c|}{1994} & 1995 \\
\hline Carbon Dioxide $\ldots \ldots \ldots \ldots \ldots \ldots \ldots \ldots \ldots \ldots \ldots \ldots \ldots$ & $5,037.1$ & $4,987.3$ & $5,059.8$ & $5,175.9$ & $5,256.1$ & $5,296.9$ \\
Methane (Full Molecular Weight) $\ldots \ldots \ldots \ldots \ldots \ldots \ldots \ldots$ & 31.6 & 31.6 & 31.7 & 30.8 & 31.4 & 30.9 \\
Methane (Carbon Dioxide Equivalent) $\ldots \ldots \ldots \ldots \ldots \ldots$ & 663.6 & 663.6 & 665.7 & 646.8 & 659.4 & 648.9 \\
\hline
\end{tabular}

Source: Energy Information Administration, Emissions of Greenhouse Gases in the United States 1996, DOE/EIA-0573(96) (Washington, DC, October 1997).

\footnotetext{
${ }^{43}$ Energy Information Administration, Emissions of Greenhouse Gases in the United States 1996, DOE/EIA-0573(96) (Washington, DC, October 1997).

${ }^{44} \mathrm{All}$ of the 43 projects reported for 1994 during the previous reporting cycle were reported again for 1995. An additional 15 projects were reported for 1995 during this reporting cycle.
} 
Table 9. Total Reported Methane Emissions Reductions, Data Years 1991-1995

(Metric Tons)

\begin{tabular}{|c|c|c|c|c|c|}
\hline Reporting Form & 1991 & 1992 & 1993 & 1994 & 1995 \\
\hline \multicolumn{6}{|l|}{ EIA-1605 } \\
\hline Direct Reductions & 6,303 & 6,885 & 9,557 & 20,981 & 8,269 \\
\hline Indirect Reductions & 47,351 & 83,842 & 91,249 & 104,608 & $1,065,548$ \\
\hline EIA-1605EZ & NA & NA & NA & 24,523 & 50,554 \\
\hline
\end{tabular}

NA = not available.

Source: Energy Information Administration, Forms EIA-1605 and EIA-1605EZ, "Voluntary Reporting of Greenhouse Gases."

in direct emissions. ${ }^{45}$ The most frequently reported method of reducing methane emissions was by recovering methane for energy. There were 41 such projects, 39 of which used the recovered methane to generate electricity, which was then used on-site or sold to a utility. Two projects sold recovered methane as pipeline-quality gas. In addition to the methane recovery projects, two projects used refuse-derived fuel, combusting waste rather than sending it to a landfill where it would decompose and generate methane emissions. One project was an experimental study on reducing rice field emissions. ${ }^{46}$

\section{Emissions Reductions by Source}

There are three principal sources of methane emissions: waste generation and disposal; energy production and distribution; and agriculture. Emissions from waste generation and disposal represent about one-third of total U.S. methane emissions, having declined steadily since 1990 as waste reaching landfills decreased and the volume of methane recovered increased (Figure 22). Emissions from energy production and distribution represent slightly more than 36 percent of all U.S. methane emissions. There are two major contributors to emissions from energy production and distribution: emissions from the oil and natural gas system from unintended leaks or vented associated gas; and fugitive emissions from coal mines during production. These two sources are discussed separately below. Twentynine percent of U.S. methane emissions can be traced to agricultural sources. More than 90 percent of emissions from agricultural sources result from animal husbandry,
Figure 22. U.S. Methane Emissions by Source, 1990 and 1995

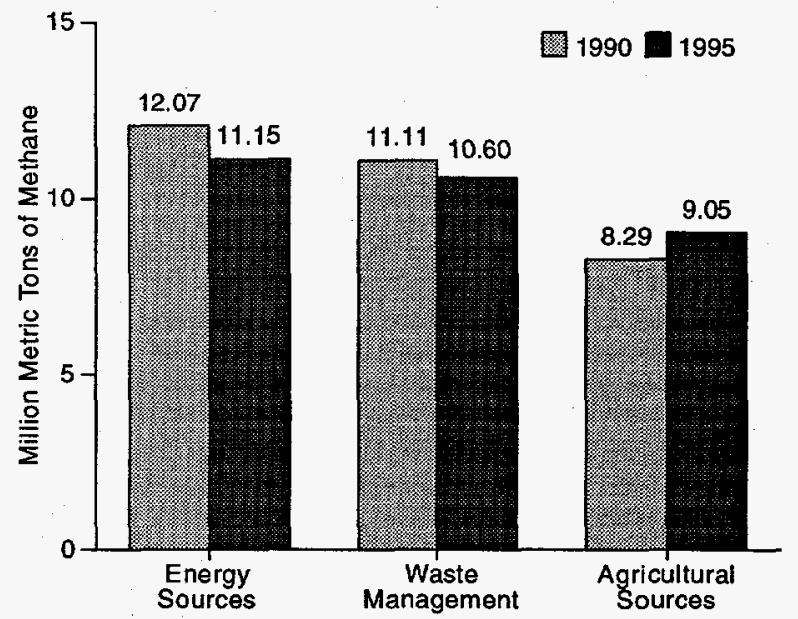

Source: Energy Information Administration, Emissions of Greenhouse Gases in the United States 1996, DOE/EIA-0573(96) (Washington, DC, October 1997).

with about two-thirds of that share traced to enteric fermentation and one-third emitted from animal wastes.

\section{Methane Emissions from Waste Generation and Disposal}

\section{Trends in U.S. Emissions}

Estimated U.S. methane emissions attributed to waste generation and disposal have declined steadily since reaching more than 11 million metric tons in 1990 . For 1995, an estimated 10.6 million metric tons of methane

\footnotetext{
${ }^{45}$ Direct emissions are from sources owned by the reporting entity. Indirect emissions are from sources outside the reporting entity that are affected by the reduction activities.

${ }^{46}$ There were several instances of double reporting that somewhat inflate the total number of projects reported. In one instance, a landfill gas-to-energy developer and the utility purchasing electricity from the developer reported the same project (see "Reporting Issues" at the end of this chapter). Two reporters reported one project each for the carbon dioxide emissions reductions and the methane emissions reductions attributable to their projects. This was an effect of the constraints imposed on reporters using the short form EIA-1605EZ, which allows the reporting of only one gas per project. Thus, if a reporter wishes to capture the carbon dioxide effects of a methane reduction project, it must be presented as two projects. Accounting for these instances of double reporting, 55 distinct activities to reduce methane emissions were reported.
} 
emissions can be traced to waste generation and disposal. Anaerobic (in the absence of oxygen) decomposition of waste in landfills is responsible for more than 98 percent of that total. ${ }^{47}$ Thus, the trend of diminishing emissions is largely the result of substantial increases in the share of waste being recycled or incinerated rather than landfilled between 1990 and 1995 and a near doubling in recovery of methane generated at landfills. Recovered methane may be flared or used to generate energy. The most frequently reported methane reduction activity was recovery for energy use.

\section{Reduction Activities Reported}

There were 39 projects reported that reduced methane emissions from waste generation and disposal, accounting for more than 1 million metric tons of reductions in 1995, nearly 9 times 1994 levels (Table 10). The 39 projects accounted for 99 percent of the total reported methane emissions reductions for 1995. This rapid escalation can be attributed to one waste-to-energy project reported by the Integrated Waste Services Association (IWSA), which accounts for more than 90 percent of the reductions from waste generation and disposal reported for 1995. The report included reductions for 1995 but not for previous years. The IWSA membership includes 65 of the Nation's 114 waste-to-energy facilities, and the report included the activities of the full membership, a total of 944,000 metric tons of indirect emissions reductions in 1995 (see box on page 52).

Though accounting for smaller reductions per individual project than the refuse-to-energy project reported by the IWSA, anaerobically generated biogas-to-energy projects were reported more often as a method for reducing methane emissions from waste generation and disposal. There were 36 such projects reported for 1995: 33 converted landfill gas to electricity, which was then consumed on-site or sold to a utility; 2 converted bio- gas from anaerobic digesters filled with wastewater to electricity; and 1 used cleaned landfill gas in natural gas pipelines. The typical biogas-to-energy project reduced emissions by between 1,000 and 10,000 metric tons, with four projects reducing between 10,000 and 20,000 metric tons in 1995. Reports for nine of the landfill gas-to-energy projects and one wastewater treatment project included estimates of the energy content of the recovered gas. Eight reported energy contents between 400 and 650 Btu per standard cubic foot, and two reported more than $900 \mathrm{Btu}$ per standard cubic foot for gas that had been cleaned to pipeline quality.

Twenty of the biogas-to-energy projects were reported by utilities that purchased either electricity generated from combusted methane or gas cleaned sufficiently to be transported via pipeline. Sixteen were reported by landfill gas-to-energy developers-14 on Form EIA$1605 \mathrm{EZ}$, likely reflecting the smaller staff and resources available to landfill gas developers. Ten of these projects were reported by Zahren Alternative Power Corporation (ZAPCO), a developer of landfill-gas-toenergy projects. Three methane recovery projects did not use the methane for energy but flared it, which has the effect of substituting the much lower warming effect of carbon dioxide for that of methane.

\section{Federal Programs To Reduce Methane Emissions from Waste Generation and Disposal}

Landfills are the largest single source of U.S. methane emissions, and the majority of emissions can be traced to approximately 700 of the Nation's largest landfills. This, together with the economic value of recovered methane, has made landfills potential candidates for government initiatives to reduce emissions. Because landfills pose other pollution concerns, such as volatile organic compound (VOC) emissions and groundwater contamination, they have a long history of regulation at

\section{Table 10. Reported Methane Emissions Reductions from Waste Generation and Disposal Projects, Data Years 1991-1995}

(Metric Tons)

\begin{tabular}{|c|c|c|c|c|c|}
\hline Reporting Form & 1991 & 1992 & 1993 & 1994 & 1995 \\
\hline \multicolumn{6}{|l|}{ EIA-1605 } \\
\hline Direct Reductions & 1,787 & 1,096 & 648 & 980 & 619 \\
\hline Indirect Reductions & 47,130 & 83,626 & 91,008 & 104,333 & $1,061,708$ \\
\hline ElA-1605EZ & NA & NA & NA & 24,388 & 50,325 \\
\hline
\end{tabular}

$\mathrm{NA}=$ not available.

Source: Energy Information Administration, Forms EIA-1605 and ElA-1605EZ, "Voluntary Reporting of Greenhouse Gases."

\footnotetext{
${ }^{47}$ Energy Information Administration, Emissions of Greenhouse Gases in the United States 1996, DOE/EIA-0573(96) (Washington, DC, October 1997).
} 


\section{Integrated Waste Services Association: Reducing Emissions Through Waste-to-Energy Facilities}

Integrated Waste Services Association (IWSA) is a national trade group whose members represent 65 of the 114 waste-to-energy facilities operating in the United States. According to the IWSA, these 65 facilities processed an estimated 31.3 million short tons of waste in 1995, providing 2,650 megawatts of electric generation capacity. IWSA assumed that 20 percent of the electricity generated was consumed internally or lost due to unit downtime, and 80 percent was exported to the electric grid. These waste-to-energy facilities also generated about 1.4 million pounds of steam (the equivalent of 1,400 million $\mathrm{Btu}$ ) per hour for export.

IWSA assumed that the municipal and industrial solid waste consumed in member facilities would have otherwise been placed in landfills. As waste decomposes in a landfill, both carbon dioxide and methane are generated. Carbon dioxide emissions result from aerobic decomposition and methane emissions from anaerobic decomposition. The IWSA assumes that 55 percent of the emissions from decomposition are carbon dioxide and 45 percent are methane, occurring over a period of 30 years, during which 60 percent of the waste decomposes. The IWSA report includes only the volume of waste diverted during 1995, but its emissions reduction estimate for 1995 includes the effects of waste diverted since 1987. The result is estimated reductions of just under 1 million metric tons of methane and 2.1 million metric tons of carbon dioxide from avoided decomposition at landfills in 1995.

IWSA also reported some offsetting emissions effects from the combustion of waste to generate electricity, estimating that combustion resulted in emissions of 28.4 million metric tons of carbon dioxide. The use of waste-to-energy facilities offset an estimated 8.97 million short tons of bituminous coal consumption, reducing emissions at electric power plants by more than 20 million metric tons, resulting in a net increase from fuel combustion during 1995 of more than 8 million metric tons of carbon dioxide. On an energy equivalent basis, the emissions rate for waste energy is about 2.5 percent lower than that for bituminous coal; however, the heat rate of waste-to-energy facilities is nearly 50 percent higher than that for coal-fired utility boilers, requiring more energy input for the same electricity output, which explains the net increase in emissions.

Despite the increase in net emissions of carbon dioxide, overall GWP-weighted emissions were reduced as a result of the activities reported by IWSA, because the GWP for methane is 21 times that for carbon dioxide over a 100-year time horizon. Also, IWSA did not measure or report the emissions reduction associated with exported steam heat, which would offset some of the increased emissions from combustion. the State and Federal levels. On March 12, 1996, the U.S. Environmental Protection Agency (EPA) implemented the New Source Performance Standards (NSPS) and Emission Guidelines (EG), which require all landfills with more than 2.5 million metric tons of waste in place and annual emissions of nonmethane volatile organic compounds (NMVOCs) exceeding 50 metric tons to collect and combust their landfill gas. The product of combustion may be flared or used as an energy resource. According to EPA estimates of landfill sizes and NMVOC emissions, this regulation should affect about 300 of the Nation's largest landfills, doubling the number recovering methane. The Climate Change Action Plan envisions emissions reductions of 15.4 million metric tons carbon dioxide equivalent, or 734,000 metric tons of methane, in 2000 as a result of these regulations. ${ }^{48}$
The EPA also sponsors a voluntary Landfill Methane Outreach Program (LMOP), which works with municipal solid waste landfill owners and operators, States, tribes, utilities, and other Federal agencies to promote the use of landfill gas to generate electricity or as a medium-Btu boiler fuel. Among its primary targets are those landfills affected by the NSPS and EG that will be required to recover and combust methane. By selling the energy from recovered methane, landfill operators may recover some of the capital cost incurred in complying with the new regulations. Under the Climate Change Action Plan, LMOP is expected to reduce methane emissions by 4 million metric tons carbon dioxide equivalent, or almost 200,000 metric tons of methane, by $2000 .{ }^{49}$ The eight reported projects that cited. LMOP affiliations showed reductions of 66,000 metric tons of methane for 1995.

\footnotetext{
${ }^{48}$ President William J. Clinton, The Climate Change Action Plan (Washington, DC, October 1993), p. 36.

${ }^{49}$ President William J. Clinton, The Climate Change Action Plan (Washington, DC, October 1993), p. 37.
} 


\section{Methane Emissions from Energy Production and Distribution: Natural Gas Systems}

\section{Trends in U.S. Emissions}

Methane emissions from the U.S. oil and natural gas system grew slowly between 1990 and 1994 due to increases in both natural gas consumption and miles of pipeline in the gas distribution system. In 1995, a sharp, temporary, and unexplained drop in the volume of associated gas vented to the atmosphere reduced emissions from the oil and natural gas system. This drop did not effect trends in the natural gas distribution system, and when 1996 saw a more typical volume of gas vented, U.S. emissions resumed their slow upward trend. Estimated emissions of methane from the oil and natural gas system stood at 6.8 million metric tons in 1996, up from 6.6 million metric tons in $1990 .^{50}$

\section{Reduction Activities Reported}

Thirteen projects reported reduced emissions from the natural gas system for 1995, two more than for the previous reporting cycle. Together, these 13 projects eliminated about 7,000 metric tons of methane emissions in 1995, down by about 24 percent from reductions reported from 13 projects for 1994 (Table 11). All reported projects focused on reducing or controlling emissions from the natural gas transmission and distribution system. Twelve of the projects involved one of two activities: (1) a change in operation and maintenance practices, such as reducing pipeline blowdowns, directed inspection and maintenance of controllers at gate stations, or reducing venting of compressed natural gas cylinders; or (2) equipment replacement and upgrade, typically in the form of pipeline repair and replacement. The other project, reported by Montana Power Company, involved the installation of catalytic converters at gas plants to reduce emissions of carbon monoxide and nitrogen oxides, with no reported effect on methane emissions.

Five of the projects to reduce methane emissions from the natural gas system were reported on Form EIA$1605 E Z$ by Brooklyn Union Gas. Four of these projects reduced methane emissions by less than 10 metric tons in 1995, but Brooklyn Union's project to rehabilitate leaky pipe saved more than 220 metric tons of methane in 1995. The remaining eight projects affecting the natural gas system were reported by seven different electric and gas utilities. Of the seven methane reduction projects reported on the long form, three saved less than 100 metric tons, three saved between 100 and 1,000 metric tons, and one project saved more than 1,000 metric tons during 1995. All the reductions reported for years prior to 1995 were characterized as direct because they typically involved activities to reduce fugitive emissions from transmission and distribution systems owned by the project reporter; however, 1995 reports showed a nearly even distribution between direct and indirect emissions reductions. The shift is attributable to a change in ownership. After completing system replacement and upgrades, Western Resources sold a portion of its natural gas distribution system to Columbia Gas. For the portion of the system that was sold, Western Resources reported emissions reductions from system replacement and upgrades as indirect, shifting about 3,000 metric tons of reductions reported as direct in 1994 to indirect in 1995.

\section{Federal Programs To Reduce Methane Emissions from the Oil and Natural Gas System}

Regulation of the oil and natural gas production and distribution industries has typically been of the economic rather than environmental variety, and much of it has fallen by the wayside over the past several

Table 11. Reported Methane Emissions Reductions from Natural Gas System Projects, Data Years 1991-1995 (Metric Tons)

\begin{tabular}{|c|c|c|c|c|c|}
\hline Reporting Form & 1991 & 1992 & 1993 & 1994 & 1995 \\
\hline \multicolumn{6}{|l|}{ EIA-1605 } \\
\hline Direct Reductions & 3,846 & 4,168 & 6,261 & 9,092 & 3,460 \\
\hline Indirect Reductions & 0 & 0 & 0 & 0 & 3,265 \\
\hline EIA-1605EZ & NA & NA & NA & 135 & 230 \\
\hline
\end{tabular}

NA $=$ not available.

Source: Energy Information Administration, Forms EIA-1605 and EIA-1605EZ, "Voluntary Reporting of Greenhouse Gases."

\footnotetext{
${ }^{50}$ Energy Information Administration, Emissions of Greenhouse Gases in the United States 1996, DOE/EIA-0573(96) (Washington, DC, October 1997).
} 
years. Because most emissions of methane from the natural gas transmission and distribution system represent a direct economic loss to system owners, it is not necessary to mandate that they avoid such losses. Instead, Federal efforts have focused on providing technical and institutional assistance to the oil and natural gas industry through EPA's voluntary Natural Gas STAR program.

The Natural Gas STAR program aims to reduce methane emissions by introducing and promoting costeffective technologies and practices throughout the natural gas industry. The program provides implementation guidelines, technical assistance, and an information sharing network for gas companies. The goal of the Natural Gas STAR program is to reduce emissions by 11 million metric tons carbon dioxide equivalent, or about 524,000 metric tons of methane, by 2000 . According to the EPA, Natural Gas STAR reduced methane emissions by 205,000 metric tons in 1994 and an additional 290,000 metric tons in 1995. Nine of the 13 reported projects were undertaken in cooperation with the Natural Gas STAR program. Together they reduced methane emissions by nearly 700 metric tons in 1995 .

\section{Methane Emissions from Energy Production and Distribution: Coal Mining}

\section{Trends in U.S. Emissions}

U.S. methane emissions from coal mining were nearly 4 million metric tons in 1995, more than 14 percent below 1990 levels, primarily because of decreased emissions from the ventilation and degasification systems of the Nation's gassiest coal mines and growing methane recovery from coal mines. ${ }^{51}$

\section{Reduction Activities Reported}

Three reported projects recovered methane from coal mines in 1995. Together, these three projects showed emissions reductions of 4,469 metric tons, almost 10,000 metric tons below the reductions reported for 1994 . Northwest Fuel Development, Inc., sold a seven-eighths interest in its project that recovers methane from an abandoned coal mine to Columbia Gas, which is now distributing the gas through its pipelines. Columbia Gas did not report to the Voluntary Reporting Program. Thus, the reductions continue, but they no longer appear in the Voluntary Reporting Program database.
In addition to Northwest Fuel Development, Cinergy Corporation and Peabody Holding Company reported projects that reduced methane emissions from coal mines. Cinergy Corporation reported purchases by its subsidiary, PSI Energy, of electricity generated using methane from a closed and abandoned underground mine. This project reduced methane emissions by 278 metric tons in 1995. Northwest Fuel Development, Inc., reported a similar project in which an internal combustion engine is used to generate electricity from methane recovered at the abandoned Nelms \#1 mine in Cadiz, Ohio. The electricity is supplied to Harrison Mining for use at a nearby mine. Excess production is sold to American Electric Power's Ohio Power Company. This project reduced methane emissions by 571 metric tons. Peabody Holding Company's project recovered pipeline-quality gas from a coal mine and delivered it directly into the natural gas distribution system, reducing emissions of methane by 3,620 metric tons. The CONSOL Coal Group also reported very large reductions in methane emissions from coal mines as part of an entity-level report but chose not to report on the project level (see box on page 55).

\section{Federal Programs To Reduce Methane Emissions from Coal Mining}

Federal regulation of the coal mining industry has historically focused on maintaining safety. Because methane in concentrations above 5 percent is explosive, coal mine operators have been required to provide sufficient ventilation to reduce methane levels in coal mines to below 2 percent. For many years, methane was viewed as a hazard and a nuisance. Only recently has it been recognized as a recoverable energy resource. The EPA has endeavored to encourage recovery through the voluntary Coalbed Methane Outreach Program (CMOP), which works with coal mines and related industries to encourage the recovery and use of methane that would otherwise be emitted to the atmosphere during mining operations. Program activities include profiling conditions at the gassiest coal mines; conducting site-specific assessments; and working with government agencies to reduce barriers to project development. The CMOP seeks to reduce emissions by 8.1 million metric tons carbon dioxide equivalent, or almost 400,000 metric tons of methane, by 2000 . The project reported by Peabody Holding Company was the only reported project associated with the CMOP.

\footnotetext{
${ }^{51}$ Energy Information Administration, Emissions of Greenhouse Gases in the United States 1996, DOE/EIA-0573(96) (Washington, DC, October 1997).
} 


\section{CONSOL Coal Group: Reducing Emissions of Coalbed Methane}

CONSOL Coal Group is one of the top ten producers and distributors of coal, operating some of the largest producing coal mines in the United States. Some of those mines are in the Nation's gassiest coal seams. Through a combination of changes in mining operations, sale of recovered coalbed methane, and internal use of coalbed methane as a fuel, CONSOL reported a reduction in methane emissions of about 525,000 metric tons in 1995, from a 1990 baseline of 1.4 million metric tons of emissions. The 1990 baseline estimate represents roughly one-third of total estimated U.S. emissions from coal mines during that year, and the 525,000-metric-ton reduction is nearly equivalent to the estimated decline in U.S. emissions from coal mines between 1990 and 1995.

Emissions estimates were supplied for 1990, 1994, and 1995, based on recorded measurements where possible and best estimates if measurements were unavailable. In 1993, CONSOL acquired Island Creek Coal Company, whose mines are located in a very gassy coal seam in Buchanan County, Virginia. Parallel to the financial accounting of mergers, acquisitions, and divestments guided by standard accounting practices, CONSOL has "restated" 1990 emissions to include emissions from the acquired Island Creek mines. Through selective mine closure and methane recovery for pipeline sales, CONSOL has reduced emissions from the mines substantially.

\section{Methane Emissions from Agriculture}

\section{Trends in U.S. Emissions}

In 1995, methane emissions from agricultural sources were just over 9 million metric tons, 9 percent higher than 1990 levels but slightly below 1994 levels. More than 90 percent of methane emissions from agriculture can be traced to animal husbandry, with about twothirds of that share traced to enteric fermentation and one-third emitted from animal wastes. Emissions from both sources are largely driven by animal sizes and populations. Between 1990 and 1994, emissions from animal sources grew steadily as animal populations and animal sizes increased, but they have since begun to recede as animal populations have decreased..$^{52}$

\section{Reduction Activities Reported}

Two reported projects reduced methane emissions from agriculture, both of which recovered methane generated anaerobically from animal wastes. No projects were reported that reduced emissions from enteric fermentation. The two projects were reported by General Public Utilities (GPU). In the first project, waste from dairy cows at the Mason Dixon Farms in Gettysburg, Pennsylvania, decomposed in an anaerobic digester, and the methane produced was used to generate electricity for on-site energy needs, with any excess sold to GPU. In the other project, electricity was generated from methane recovered from the decomposing waste of swine owned by Valley Pork, Inc., of Seven Valleys, Pennsylvania. Again, electricity was used on-site, and any excess was sold to GPU. Together, these two projects were responsible for emissions reductions of $\mathbf{3 0 0}$ metric tons in 1995, up by 9 percent from 1994.

An additional reported project described a study of methods to reduce methane emissions from wetland rice cultivation. The results of the study have not yet been implemented, and no associated emissions reductions were reported.

\section{Federal Programs To Reduce Methane Emissions from Agriculture}

The Federal Government sponsors the Ruminant Livestock Efficiency Program-a cooperative effort of the U.S. Department of Agriculture and the EPA-to provide research and demonstration projects aimed at reducing methane emissions from dairy and beef cattle due to enteric fermentation. Initiatives are aimed at improving nutrition through mechanical and chemical feed processing and strategic supplementation, genetic improvements, and disease control. The program is slated to reduce emissions by 6.6 million metric tons carbon dioxide equivalent, or more than 300,000 metric tons of methane, by 2000 .

To encourage the capture and use of methane produced from the anaerobic decomposition of animal waste, the EPA the U.S. Department of Energy, and the U.S. Department of Agriculture sponsor the AgSTAR program. As part of this program, participating producers commit to survey their facilities to identify profitable options for capture and use of methane as an on-site power source. The program includes demonstration projects and decision support software. AgSTAR is expected to contribute reductions of 5.5 million metric tons carbon dioxide equivalent, or about 260,000 metric tons of methane, under the CCAP.

\footnotetext{
${ }^{52}$ Energy Information Administration, Emissions of Greenhouse Gases in the United States 1996, DOE/ELA-0573(96) (Washington, DC, October 1997).
} 


\section{Reporting Issues}

\section{Double Reporting}

Many methane recovery projects provide the opportunity for double reporting; however, this should not be confused with double counting. Typically, a methane recovery project involves two or more parties: the party that recovers the gas, such as a landfill developer, wastewater treatment facility, livestock farm, or coal mine; and the party that uses the energy contained in the recovered methane, such as a utility or natural gas pipeline company. The party that recovers the gas reports the reduction as direct, since the emission would have occurred at that facility. The purchaser of the energy produced from the gas reports the reduction as indirect, since the reduction occurred at the seller's facility. Thus, the project is double reported. It is not double counted, however, because indirect and direct emissions reductions can be examined separately. Where double counting may occur, it will be restricted to indirect emissions when multiple reporters claim activities that affect emissions from a single source they do not own. (For a more extensive discussion of multiple reporting, see Appendix A, "Emissions Accounting Issues.")

The landfill gas recovery project at Hamm's landfill is an excellent example of how multiple reporters can provide information on a project without causing double counting. The developer of Hamm's landfill, Zahren Alternative Power Corporation (ZAPCO) reported direct methane reductions from the landfill of 1,575 metric tons during 1995. General Public Utilities (GPU) purchased the electricity generated at the landfill by ZAPCO and reported indirect methane emissions reductions of 1,475 metric tons during 1995. The difference in reductions claimed does not reflect inaccuracy on the part of either party but rather reflects the estimation methods used and the point in the fuel cycle at which emissions were measured. ZAPCO estimates reductions on the basis of metered gas recovery data. GPU estimates reductions on the basis of megawatthours of electricity purchased. The difference in the estimates is driven by assumptions about heat rate that GPU must make to take into account the energy losses associated with generation and transmission.

Today, reductions in emissions have no legislatively mandated economic value, nor has a system of property rights been established for either emissions or reductions. Thus, all contributors to an emissions reduction project may wish to report their reductions either as direct or indirect, as appropriate. In some cases, when multiple parties have contributed to a project, the parties have established contractual rights to report the emissions reductions.

\section{Methane Recovery as a Proxy for Emissions Reductions}

Most methane reduction projects use metered volumes of methane recovery as a proxy for estimating emissions reductions. This is not surprising, as it provides the most accessible and measurable data for estimating reductions. However, this method may overestimate actual reductions, because it assumes that all methane recovered would have been vented to the atmosphere. A few examples reveal that this may not necessarily be the case.

Methane recovered from animal waste is typically obtained by placing waste in a liquid system, such as an anaerobic digester. Such a system is specifically designed to maximize methane output. If the waste in the anaerobic digester were simply spread over pasture land, it would decompose aerobically and produce almost no methane. Similarly, absent degasification, the ultimate disposition of methane removed from a coal seam before mining is uncertain. The coal seam might never have been mined, ruling out emissions, or the methane might have remained in cracks and fissures of the coal seam or in portions of unmined coal. Methane from landfills is recovered by dropping wells into the waste and using a vacuum to pull out biogas. It is uncertain how much of the gas recovered would have been emitted otherwise, or when it would have been emitted. Some might have migrated into groundwater or been oxidized in cover soils, and some might have been permanently trapped in the landfill. Thus, while recovery data currently provide the best and easiest method for estimating emissions reductions, the method is imperfect.

\section{The Role of Carbon Sequestered in Waste in the Global Carbon Cycle}

In estimating emissions reductions from waste diversion or methane recovery projects, an understanding of the role of the carbon sequestered in waste relative to the global carbon cycle is important. Several approaches can be taken. Some reporters view the carbon contained in waste as part of the carbon cycle and, thus, as having no effect on emissions levels. This view is taken because the carbon portion of the organics in waste such as food and paper was fixed in those products through normal carbon uptake and, upon decomposition, will once again be fixed in plants, trees, animals, and the oceans. Others argue that the use of natural products for food or paper removes fixed carbon which, through decomposition, will be added to anthropogenic emissions of methane and carbon dioxide. Although both arguments have merit, it is a question that is unlikely to be resolved in the context of the Voluntary 
Reporting Program. Nevertheless, for an emissions reduction report, the role of carbon in waste should be treated in a consistent manner.

For example, when estimating reductions from a wasteto-energy project, a reporter may wish to assume that the carbon released from the waste during combustion is part of the normal carbon cycle, and thus that the reductions are equal to the full magnitude of the fossil fuel generation displaced. If so, the reporter should not also report the reductions in emissions from a landfill that would otherwise have received that waste, because the reporter has defined the methane and carbon dioxide that would have been released as part of the normal carbon cycle. If a methane recovery project is reported, the carbon contained in the methane has been defined as not part of the normal carbon cycle; thus, the carbon dioxide emissions from combusting that methane through flaring or for energy should be reported. 



\section{Halogenated Substances and Other Gases}

\section{U.S. Emissions of Halogenated Substances and Other Gases in Perspective}

Emissions of halogenated substances and other gasesall of which have relatively high global warming potential (GWP) - can be grouped into two classes according to their effects on global climate. In the first group are chlorofluorocarbons (CFCs), hydrochlorofluorocarbons (HCFCs), and other chlorine-containing gases. Because these gases contain chlorine, they have a tendency to react with ozone in the upper stratosphere, diminishing the concentration of ozone, which is itself a greenhouse gas. The resulting reduction in ozone offsets, to an undetermined degree, the absorption of infrared radiation associated with the chlorinated gases. As a result, the effect of these gases on global climate is ambiguous.

In contrast, the second class of gases discussed in this chapter-halocarbons, hydrofluorocarbons (HFCs), perfluorocarbons (PFCs), and sulfur hexafluoride-do not combine with ozone and therefore have less ambiguous effects on climate. Thus, their overall relative contribution to U.S. GWP-weighted emissions can be more readily evaluated. U.S. emissions of HFCs grew by nearly 60 percent between 1990 and 1995, emissions of perfluorocarbons by 24 percent, and emissions of sulfur hexafluoride by 29 percent. Despite the rapid increases, these gases still represent only about 2.5 percent of national GWP-weighted greenhouse gas emissions (Table 12).

\section{Projects Reported}

There were 22 projects that reduced emissions of CFCs, HFCs, HCFCs, PFCs and other high-GWP gases such as methyl chloroform and sulfur hexafluoride reported for 1995, an increase of 47 percent over the number of such projects reported for $1994 .{ }^{53}$ The 22 projects were reported by 15 separate entities, including 12 utilities, 2 aluminum companies, and 1 chemical company. The projects reported had one of three primary goals: (1) reductions in emissions of CFCs; (2) reductions in emissions of PFCs; and (3) reductions in emissions of sulfur hexafluoride.

\section{Emissions Reductions by Gas}

Emissions reductions were reported for three separate chlorofluorocarbons: CFC-11, CFC-12, and CFC-113. Most CFC reductions are attributed to CFC-12, with total reductions of more than 3,200 metric tons reported for 1995 (Table 13). ${ }^{54}$ Reductions reported for CFC-11 and CFC-113 totaled less than 5 metric tons for 1995. Emissions reductions for two PFCs, perfluoroethane

Table 12. Estimated U.S. GWP-Weighted Emissions of Greenhouse Gases, 1990-1995

(Million Metric Tons Carbon Dioxide Equivalent)

\begin{tabular}{c|r|r|r|r|r|r}
\hline Gas & 1990 & 1991 & 1992 & 1993 & 1994 & 1995 \\
\hline HFCs, PFCs, and SF $_{6} \ldots \ldots \ldots \ldots$ & 92 & 96 & 103 & 99 & 113 & 132 \\
Carbon Dioxide $\ldots \ldots \ldots \ldots \ldots$ & 5,037 & 4,987 & 5,060 & 5,176 & 5,256 & 5,297 \\
Nitrous Oxide $\ldots \ldots \ldots \ldots \ldots \ldots$ & 139 & 140 & 140 & 143 & 146 & 141 \\
Methane $\ldots \ldots \ldots \ldots \ldots \ldots$ & 664 & 664 & 666 & 647 & 659 & 649 \\
Total $\ldots \ldots \ldots \ldots \ldots \ldots$ & 5,931 & 5,888 & 5,970 & 6,066 & 6,174 & 6,219 \\
\hline
\end{tabular}

$\mathrm{HFCs}=$ hydrofluorocarbons. $\mathrm{PFCs}=$ perfluorocarbons. $\mathrm{SF}_{6}=$ sulfur hexafluoride.

Source: Energy Information Administration, Emissions of Greenhouse Gases in the United States 1996, DOE/EIA-0573(96). (Washington, DC, October 1997).

\footnotetext{
${ }^{53}$ One of 15 projects reported for 1994 was not reported for 1995, 14 projects were reported for both 1994 and 1995 , and 8 projects were newly reported for 1995 .

${ }^{54}$ These totals aggregate direct and indirect reductions and thus introduce the potential for double counting. Reported indirect reductions of CFC-12 were 6.89 metric tons in 1995, and reported indirect reductions of CFC-11 were 1.75 metric tons. No indirect reductions were reported for CFC-113.
} 
Table 13. Reported Halocarbon Emissions Reductions, Data Years 1991-1995

\begin{tabular}{|c|c|c|c|c|c|}
\hline Gas & 1991 & 1992 & 1993 & 1994 & 1995 \\
\hline CFC-11 & 0.00 & 0.00 & 1.24 & 3.04 & $\mathrm{a}_{4.08}$ \\
\hline CFC-12 & 27.70 & $2,511.20$ & $2,929.60$ & $3,180.00$ & $3,231.10$ \\
\hline CFC-113 & 0.00 & 0.00 & 0.03 & 0.03 & 0.33 \\
\hline Perfluoroethane $\ldots \ldots \ldots \ldots$ & 38.97 & 42.43 & 40.93 & 45.78 & 42.50 \\
\hline Perfluoromethane .......... & 391.69 & 428.26 & 414.18 & 465.77 & 431.00 \\
\hline .Sulfur Hexafluoride $\ldots \ldots \ldots \ldots$ & 1.57 & 2.24 & 8.59 & 10.29 & 8.72 \\
\hline HCFC-22 & 0.00 & 0.00 & 0.10 & 1.02 & 0.26 \\
\hline Methyl Chloroform .......... & 0.00 & 0.00 & 0.00 & 3.21 & 8.02 \\
\hline Other & 0.00 & 0.00 & 0.47 & 0.47 & 0.47 \\
\hline
\end{tabular}

ancludes 1.27 metric tons reported on Form EIA-1605EZ.

Note: Direct and indirect reductions have been aggregated, introducing the possibility of double counting; however, total indirect reductions of all the compounds shown did not exceed 40 metric tons in any year, and only for CFC-11 and HCFC-22 do indirect reductions make up a significant share of the total reductions shown.

Source: Energy Information Administration, Forn EIA-1605, "Voluntary Reporting of Greenhouse Gases."

and perfluoromethane, were reported. These reductions were somewhat less than those reported for CFC-12, but their respective GWPs of 9,200 and 6,500 magnify the importance of even small reductions of PFC gases. Reported reductions of sulfur hexafluoride were small in nominal terms but significant relative to the very low aggregate level of national emissions of the gas. Reductions were also reported for HCFC-22 and methyl chloroform as parts of projects that recovered other gases, but specific information on methods used to reduce emissions of these gases was not provided. Emissions of several CFC substitutes (HCFC-123, HCFC-142b, and HFC-134a) increased as they displaced other compounds as blowing agents and as coolants (Table 14).

\section{Chlorofluorocarbons}

\section{Trends in U.S. Emissions}

Driven by the phaseout required under the Montreal Protocol, U.S, emissions of CFCs declined substantially between 1990 and 1995. Emissions of CFC-11 decreased by more than 85 percent during that period, due to its elimination as a blowing agent and a substantial reduction in the number of chillers charged with CFC-11. Emissions of CFC-12 have dropped more slowly. The use of CFC-12 as a blowing agent dropped by some 90 percent over the 5 years, but a significant amount remains in use in automobile air conditioners. Emissions of CFC- 113 were reduced by 85 percent between 1990 and 1995.55

\section{Reduction Activities Reported}

Thirteen reported projects showed reductions of CFC-12. Together, these projects reported total emissions reductions of 3,231 metric tons for 1995, a small (1.6 percent) increase from 1994 levels. This total is by far the largest reduction for any of the gases in the halocarbon or other gases category and is nearly all ( 99.5 percent) attributable to two projects reported by Dow Chemical Company. Dow Chemical reported a $\mathrm{CFC}$ refrigeration systems conversion project and the replacement of CFCs as blowing agents in worldwide operations that together eliminated more than 3,200 metric tons of CFC-12 emissions. However, Dow substituted HCFC-142b as a blowing agent, increasing emissions of that compound by more than 3,200 metric tons in 1995 (see box on page 61).

Absent the substantial reductions reported by Dow, reductions of CFC- 12 reported for 1995 would have been smaller than those reported for 1994, for two reasons: the termination of Niagara Mohawk's Refrigerator Roundup program in 1995 (because the full charge of CFC-12 is recovered at the time of refrigerator turn-in, appliances removed from service do not generate ongoing emissions reductions) and a substantial diminution in reductions achieved through Wisconsin Electric Power's appliance turn-in program. Refrigerator roundups and appliance turn-ins were the most commonly reported method for reducing emissions of CFC-12, with six such projects reported. Two of the projects also reduced CFC-11 emissions. Overall, seven

\footnotetext{
${ }^{55}$ Energy Information Administration, Emissions of Greenhouse Gases in the United States 1996, DOE/EIA-0573(96) (Washington, DC, October 1997).
} 
Table 14. Reported Increases in Emissions of CFC Substitutes, Data Years 1991-1995

(Metric Tons)

\begin{tabular}{c|r|r|r|r|r}
\hline Gas & \multicolumn{1}{c|}{1991} & \multicolumn{1}{c|}{1992} & 1993 & 1994 & 1995 \\
\hline HCFC-123 $\ldots \ldots \ldots \ldots \ldots \ldots \ldots$ & 0.00 & 0.00 & 0.00 & 0.02 & 0.08 \\
HCFC-142b $\ldots \ldots \ldots \ldots \ldots \ldots \ldots$ & 0.00 & $2,025.00$ & $2,745.00$ & $3,453.00$ & $3,269.00$ \\
HFC-134a $\ldots \ldots \ldots \ldots \ldots \ldots$ & 0.00 & 0.00 & 0.00 & 0.02 & 0.03 \\
\hline
\end{tabular}

Note: Reported direct increases in emissions of HCFC-123 totaling 0.09 metric tons in 1995 were somewhat offset by reported indirect reductions of 0.01 metric tons.

Source: Energy Information Administration, Form EIA-1605, "Voluntary Reporting of Greenhouse Gases."

projects reported reducing emissions of CFC-11 in 1995. These projects reduced CFC-11 emissions by a total of 4.08 metric tons during 1995, up from just over 3 metric tons reported for 1994 .

\section{Federal Programs To Reduce Emissions of Chlorofluorocarbons}

Chlorofluorocarbons and halocarbons are unique among greenhouse gases in that their levels of use and emissions are largely a function of the regulation of ozone-depleting substances required under the Montreal Protocol and subsequent, related treaties. Under the Copenhagen Amendments to the Montreal Protocol, as implemented by the U.S. Environmental Protection Agency, U.S. production of CFCs, with the exception of small amounts for health and safety equipment, ceased in January 1996.

\section{Perfluorocarbons}

\section{Trends in U.S. Emissions}

The principal quantifiable source of PFC emissions is aluminum smelting. PFCs are produced during aluminum production when the alumina content of the electrolytic bath falls below critical levels required by the electrolytic effect. The resulting electrical upset in the reduction cell is manifested as a rapid voltage increase. The gases formed accumulate at the reduction cell anodes (hence the name "anode effect"). Semiconductor manufacturing also results in PFC emissions. Total U.S.

\section{Dow Chemical Company: Replacing CFCs as Blowing Agents in the Manufacture of Foams}

Dow Chemical Company does not produce CFCs but has used them as blowing agents in the manufacture of foamed plastics and as a refrigerant and heat transfer fluid in operations. CFCs have very high molecular stability, allowing them to migrate to the stratosphere when they are emitted. Once in the stratosphere, they react with and transform ozone, depriving Earth of its shield against harmful ultraviolet radiation. Thus, there has been international agreement to phase out their production and use. Since January 1996, CFCs have not been produced in the United States except in very small amounts for health and safety equipment. Since 1988, Dow has steadily and substantially reduced their use, and thus their emissions, throughout worldwide operations that include plants in 30 nations.

In January 1989, Dow began replacing CFCs in its operations with HCFCs. From a 1988 peak of more than 5,500 metric tons, Dow's worldwide emissions of
CFCs were only 70 metric tons in 1995, nearly a 99percent drop. The decline was measured by reviewing purchase orders and inventories to estimate usage and incorporating the estimate into an emissions model.

Dow's use of HCFCs as CFC replacements rose sharply during the same period, from 1,600 metric tons in 1990 to nearly 5,000 metric tons in 1995. The addition of a hydrogen atom in HCFCs reduces their stability, shortening their atmospheric lifetimes and thus limiting the likelihood that they will reach the stratosphere and react with ozone. HCFCs generally have lower warming impacts than the CFCs they replace; however, because ozone is itself a greenhouse contributor, the more benign effect of HCFCs on ozone may somewhat offset the reduced direct warming effect they have relative to CFCs. The ultimate net effect on atmospheric warming from the substitution of HCFCs for CFCs is still subject to scientific inquiry. 
emissions are estimated to be between 2,000 and 3,000 metric tons annually. Because a full accounting of emissions sources is unavailable, an overall trend is difficult to discern. ${ }^{56}$

\section{Reduction Activities Reported}

Two aluminum companies, Noranda Aluminum and Alcan Ingot's Sebree Aluminum Plant, reported projects that reduced emissions of perfluoromethane and perfluoroethane. Noranda Aluminum reduced the number and duration of anode effects through the installation of computer process controls. Alcan Ingot's Sebree Aluminum Plant reduced anode effects and hence PFC emissions through reductions in production. Together, these two projects reduced emissions of perfluoromethane by 431 metric tons in 1995, a slightly smaller reduction than the 466 metric tons reported for 1994 . They also reduced emissions of perfluoroethane by some 43 metric tons, just below the reduction of 46 metric tons reported for 1994.

\section{Federal Programs To Reduce PFC Emissions}

The aluminum industry is limited to a small group of firms. The principal source of PFCs, anode effects during aluminum smelting, represent an inefficiency in production. Thus, this small group can be targeted for an economic gain. In response, the EPA has created the Voluntary Aluminum Industrial Partnership (VAIP), which seeks to reduce emissions of PFCs, carbon tetrafluoride, and sulfur hexafluoride during primary aluminum production. Reductions are achieved through improved management and technological advances within the industry. The VAIP hopes to reduce emissions of PFCs by 6.6 million metric tons carbon dioxide equivalent in 2000 .

\section{Sulfur Hexafluoride}

\section{Trends in U.S. Emissions}

Sulfur hexafluoride is used as an insulator for circuit breakers, switch gear, and other electric equipment and as a cover gas in magnesium smelting. Annual U.S. emissions of sulfur hexafluoride are estimated to have remained steady in the neighborhood of 1,000 to 1,500 metric tons since 1990, with about three-quarters attributable to electrical equipment and one-quarter to magnesium smelting. Sulfur hexafluoride has a very high GWP-23,900 times the warming effect of carbon dioxide per ton emitted. Therefore, even small amounts of sulfur hexafluoride can play a disproportionate role in U.S. contributions to climate change. ${ }^{57}$

\section{Reduction Activities Reported}

Three electric utilities reported projects to reduce emissions of sulfur hexafluoride. Duquesne Light (see box below) and General Public Utilities improved maintenance and replaced seals on their transmission systems to reduce emissions. Tucson Electric reduced sulfur hexafluoride emissions by recycling the gas and returning it to circuit breakers. Together, these projects accounted for direct emissions reductions of 8.4 metric tons in 1995, down from the 10.3 metric tons reported for 1994.

\section{Duquesne Light Company: Reducing Emissions of Sulfur Hexafluoride}

Duquesne Light Company uses sulfur hexafluoride as an insulating gas in breakers and buses at its substations. Fugitive emissions at the sites result from leakage at sealed joints. In January 1993, Duquesne initiated improved maintenance practices to identify leaky seals and replace worn gaskets. As a result, sulfur hexafluoride emissions from Duquesne's transmission and distribution system have declined from more than 12 short tons in 1992 to just above 6 short tons in 1995-a reduction of nearly 150,000 short tons in carbon dioxide equivalent emissions. This project is easily replicable throughout the electricity transmission and distribution system, and emissions reductions can be simply estimated from data on purchases of sulfur hexafluoride.

\footnotetext{
${ }^{56}$ Energy Information Administration, Emissions of Greenhouse Gases in the United States 1996, DOE/EIA-0573(96) (Washington, DC, October 1997).

${ }^{57}$ Energy Information Administration, Emissions of Greenhouse Gases in the United States 1996, DOE/EIA-0573(96) (Washington, DC, October 1996).
} 


\section{Entity-Level Emissions and Future Commitments}

\section{About Entity Reporting}

The Voluntary Reporting Program encompasses three alternative mechanisms for reporting emissions and reductions of greenhouse gases:

- Emissions reduction projects, defined as specific actions to reduce emissions of greenhouse gases from a particular source or group of sources

- Entity-level emissions and reductions, defined as reducing the emissions of an entire company or other organization

- Commitments to make reductions in emissions in the future.

These mechanisms reflect differing approaches to the problem of defining and controlling emissions. The project approach focuses on a specific action, undertaken in a particular time and place, and then endeavors to estimate (with varying degrees of precision) the emissions consequences of the action. The entity approach, on the other hand, focuses on the emissions outcome, in the form of the actual time profile of the emissions of a particular organization. The reporter then may be able to estimate (with varying degrees of precision) the causes of a change in emissions. Future commitments are promises to undertake action or achieve results in the future, and hence can ultimately be evaluated by the outcomes as reported in future reporting cycles.

This chapter examines entity-level reporting and future commitments. Entity-level reporting and project reporting are not mutually exclusive: most entity reporters also reported on specific projects. Both project-level and entity-level reporters described future commitments.

In 1996, 51 reporters supplied entity-level reports, a 32percent increase over the 38 entity reporters in the Voluntary Reporting Program's first year. Most (41) of the reporters were electric utilities. The nonutilities included two chemical companies (DuPont and Dow), two coal companies (Peabody and CONSOL), three manufacturers (General Motors, Johnson \& Johnson, and IBM), one aluminum smelter (Alcan), a trade association (Integrated Waste Services Association), and one household.

The coverage of the U.S. economy and U.S. emissions by entity-level reports is uneven, with good coverage of the electric utility sector but much thinner coverage of other sectors. Although there are about 3,200 electric utilities in the United States, electricity generation and sales tend to be dominated by a much smaller number of very large utilities. Some 244 large investor-owned utilities account for about 76 percent of sales (measured in kilowatthours) to ultimate consumers. A further 512 large publicly owned utilities account for about 13 percent of sales to ultimate consumers. ${ }^{58}$

Entity-level electric utility voluntary reporters accounted for 44 percent of U.S. electric utility emissions and about 10 percent of U.S. energy-related carbon dioxide emissions. Coverage in the manufacturing sector was much lower, with direct emissions accounting for about 2 percent of industrial sector emissions, and about 0.5 percent of energy-related carbon dioxide emissions.

\section{Entity-Level Emissions}

Table 15 summarizes reported entity-level emissions. As one would expect, emissions-particularly, carbon emissions-were heavily weighted toward electric utilities. Of the 856 million metric tons of direct carbon dioxide emissions from stationary sources reported for 1995, nonutilities reported only 54 million tons, of which 28 million tons was reported by the Integrated Waste Services Association, whose members burned municipal solid waste to generate electricity, and 20.5 million tons by Dow Chemical. DuPont also reported "total carbon dioxide emissions" of $\mathbf{1 2 . 2}$ million metric tons in 1995 but did not distinguish between direct and indirect emissions and hence is not included in the total.

Direct emissions from transportation sources reported are largely incidental emissions from the vehicle fleets of reporting companies. ${ }^{59}$ Since transportation emissions are dominated by households and transportation

\footnotetext{
${ }^{58}$ Energy Information Administration, Financial Statistics: Major U.S. Publicly Owned Electric Utilities 1995 (DOE/EIA-0437(95)/2 (Washington, June 1997), pp. 3-4.

${ }^{59}$ The "blip" in 1990, 1994, and 1995 transportation emissions are due to reporting on emission in those years only by a coal company.
} 
Table 15. Reported U.S. Entity-Level Carbon Dioxide Emissions by Type of Activity, 1988-1995 (Thousand Metric Tons of Carbon Dioxide)

\begin{tabular}{|c|c|c|c|c|c|c|c|c|}
\hline Type of Emission & 1988 & 1989 & 1990 & 1991 & 1992 & 1993 & 1994 & 1995 \\
\hline \multicolumn{9}{|l|}{ Direct Emissions } \\
\hline \multicolumn{9}{|l|}{ Stationary Combustion } \\
\hline 1988-1995 Reporters & 623,027 & 604,949 & 601,765 & 613,234 & 592,636 & 628,382 & 622,600 & 649,259 \\
\hline 1990-1995 Reporters & - & -- & 194,412 & 137,571 & 152,017 & 148,523 & 188,963 & 206,492 \\
\hline Total . . . . . . . . & 623,027 & 604,949 & 796,177 & 750,805 & 746,653 & 776,905 & 811,563 & 855,751 \\
\hline Transportation $\ldots \ldots$ & 175 & 175 & 676 & 174 & 170 & 162 & 606 & 620 \\
\hline \multicolumn{9}{|l|}{ Indirect Emissions } \\
\hline Purchased Power & 82,522 & 78,136 & 90,239 & 87,267 & 89,021 & 93,047 & 91,406 & 102,252 \\
\hline Electricity Wholesale & 29,178 & 34,176 & 43,442 & 35,818 & 36,988 & 33,935 & 30,259 & 35,322 \\
\hline Other (GM Vehicles) & 477,292 & 459,460 & 441,381 & 425,673 & 412,059 & 397,320 & 385,120 & 378,344 \\
\hline
\end{tabular}

Note: Not all reporters provided historical data for years prior to 1990. "1988-1995 Reporters" are the group of reporters who provided emissions data for the entire period; "1990-1995 Reporters" provided information only for 1990 and subsequent years.

Source: Energy Information Administration, Form ElA-1605, "Voluntary Reporting of Greenhouse Gases," Schedule III.

firms such as airlines and railroads (which did not report), it is not surprising that reported emissions are very low.

Indirect emissions are defined as emissions from sources other than that owned by the reporter, but caused by actions on the part of the reporter. The predominant source of indirect emissions is the purchase or sale of electricity. Both utilities and nonutilities purchase electricity, and they reported estimated "indirect" emissions based on the supposed generation mix of the seller. Most small utilities in the United States do not own their own generating capacity, but purchase power from larger utilities. Indirect emissions can thus potentially be "double reported" if the seller is a reporting utility.

Another reporting complication is illustrated by the "electricity wholesaling" figure. As noted above, many utilities sell electricity to other utilities. In the EIA reporting scheme, an emission from generation is a "direct emission," while an emission caused by the reporter's use of electricity generated by others is an "indirect emission." However, views differ on who "owns" the emissions arising from power generated on behalf of others. The "electricity wholesaling" figure was calculated on the basis of information reported by seven utilities with significant third-party sales, which took the view that their "net" emissions should exclude emissions for power generated on behalf of others. Two utilities (Allegheny and Pacificorp) accounted for the bulk of reported electricity wholesaling.

The final indirect emissions category illustrates another reporting issue. General Motors reported, as an indirect emission, the calculated emissions of the fleet of GM vehicles in operation in the United States. Since the fuel efficiency of GM's vehicles has increased in recent years, the emissions of GM-built vehicles, taken as a group, have declined. The reported emissions account for about 23 percent of U.S. transportation emissions.

Table 16 illustrates reported emissions of greenhouse gases other than carbon dioxide. Only 11 reporters described emissions other than carbon dioxide. Most of these reporters indicated only minor emissions caused by combustion of fossil fuels or refrigerant leaks. There were, however, a few reporters who provided information on significant emissions (and reductions) from gases other than carbon dioxide.

CONSOL reported on methane emissions from its underground coal mining operations. By installing degasification systems and shifting production to less gassy mines, CONSOL reported that it was able to reduce methane emissions by 43 percent between 1990 and 1994. This is the global warming equivalent of about 12 million metric tons of carbon dioxide (3.3 million metric tons carbon equivalent), or about 0.2 percent of total U.S. greenhouse gas emissions.

DuPont reported emitting around 50,000 metric tons of nitrous oxide each year from it adipic acid plants. This is the equivalent of about 13 million metric tons of carbon dioxide ( 3.6 million metric tons carbon equivalent). DuPont indicates that it intends to install control measures that will sharply reduce these emissions in the near future.

Two firms reported entity-level emissions of perfluorocarbons: an aluminum smelter and a chemical company. A single firm (Dow) reported emissions of sulfur hexafluoride. Florida Power \& Light reported reductions in emissions (but not the emissions themselves) of 
Table 16. Reported U.S. Entity-Level Emissions of Other Greenhouse Gases, 1988-1995

(Metric Tons of Gas)

\begin{tabular}{|c|c|c|c|c|c|c|c|c|}
\hline Gas & 1988 & 1989 & 1990 & 1991 & 1992 & 1993 & 1994 & 1995 \\
\hline \multicolumn{9}{|l|}{ Methane } \\
\hline Direct (Consol) & NR & NR & $1,364,049$ & NR & NR & NR & 783,407 & 837,543 \\
\hline Direct (Other Reporters) & 1,298 & 1,183 & 1,242 & 1,319 & 1,258 & 1,278 & 1,248 & 1,211 \\
\hline Indirect $\ldots \ldots \ldots \ldots \ldots \ldots$ & 400,112 & 400,024 & 400,066 & 400,022 & 400,017 & 400,063 & 300,041 & 300,055 \\
\hline \multicolumn{9}{|l|}{ Nitrous Oxide } \\
\hline DuPont & NR & NR & NR & 48,534 & 44,906 & 48,988 & 46,720 & 54,885 \\
\hline Other Reporters & 1 & 1 & 1 & 1 & 1 & 1 & 1 & 1 \\
\hline Hydrofluorocarbons & NR & NR & NR & 1,209 & 1,275 & 1,673 & 2,572 & 2,225 \\
\hline Perfluorocarbons ...... & NR & NR & NR & 203 & 130 & 131 & 130 & 129 \\
\hline Sulfur Hexafluoride & NR & NR & NR & NR & 0 & 0 & 40 & 54 \\
\hline Chlorofluorocarbons $\ldots \ldots \ldots \ldots$ & 10,901 & 7,018 & 6,531 & 6,227 & 5,819 & 5,600 & 4,749 & 4,057 \\
\hline Hydrochlorofluorocarbons ...... & NR & NR & NR & 1,761 & 2,333 & 2,764 & 2,869 & 4,734 \\
\hline Other Ozone-Depleting Chemicals & 3,465 & 1,993 & 1,741 & 868 & 329 & 591 & 292 & 208 \\
\hline
\end{tabular}

NR $=$ not reported.

Source: Energy Information Administration, Form ElA-1605, "Voluntary Reporting of Greenhouse Gases," Schedule III.

sulfur hexafluoride. In fact, small-scale emissions of sulfur hexafluoride are probably common to most electric utilities.

There were a number of reporters of chemicals currently being phased out as ozone depleters, pursuant to the Montreal Protocol, including chlorofluorocarbons (CFCs), hydrochlorofluorocarbons (HCFCs), carbon tetrachloride, chloroform, and methylene chloride. All of the organizations reporting on these chemicals indicated that emissions declined rapidly during the 1990s.

\section{Entity-Level Reductions}

Most reporting organizations described both emissions and reductions in emissions on their entity reports. (There were a few exceptions: 5 of the 51 organizations reported emissions only, in order to provide a baseline for future claims of reductions.) Table 17 summarizes the reports of emissions reductions received. Emissions reductions totaling some 106 million metric tons of carbon dioxide ( 29 million metric tons carbon equivalent) were reported for 1995, equivalent to about 2 percent of 1995 U.S. emissions.

About 21 percent of total reductions were claimed by the Integrated Waste Services Association, reporting on behalf of a large portion of the waste-to-energy capacity in the United States. The Association argues that by combusting solid waste to make electricity, its members reduce emissions from fossil fuels and also avoid methane emissions that would otherwise have been caused by anaerobic decomposition of municipal solid waste.
Other large reductions were claimed by Florida Power \& Light (22.2 million metric tons of carbon dioxide), Duke Power (12.8 million metric tons of carbon dioxide), and the Tennessee Valley Authority (10.2 million metric tons of carbon dioxide).

The concept of an emissions reduction is more complex than one might imagine. Reduction claims are principally affected by the diverse ways in which organizations defined two ambiguous reporting issues:

- The definition of the reference case

- The treatment of "indirect" emissions and reductions.

\section{The Definition of the Reference Case}

A reduction can be defined as a reduction compared with emissions at some other point in time (for example, emissions are less than they were in 1990), or as a reduction compared with an alternative state of the world (new wind turbines reduced emissions in 1995 compared to what would have been emitted if the wind turbine had not been built). The state of the world to which actual emissions are compared is called "the reference case." A reference case defined as emissions at a particular point in time (usually 1990) is a "basic reference case." A reference case defined as emissions that would have occurred if emissions reductions actions had not been taken is called a "modified reference case." The actual emissions of firms adopting a modified reference case have often (but not universally) risen over time. 
Table 17. Reported U.S. Entity-Level Carbon Dioxide Emissions Reductions by Type of Activity, 1991-1995 (Thousand Metric Tons of Carbon Dioxide)

\begin{tabular}{|c|c|c|c|c|c|}
\hline Gas & 1991 & 1992 & 1993 & 1994 & 1995 \\
\hline \multicolumn{6}{|l|}{ Direct Reductions } \\
\hline Stationary Combustion & 25,413 & 44,044 & 53,089 & 65,143 & 83,107 \\
\hline Transportation & 8 & 10 & 14 & 91 & 79 \\
\hline Other Direct Sources & 0 & * & 12 & 15 & 85 \\
\hline \multicolumn{6}{|l|}{ Indirect Reductions } \\
\hline Purchased Power & 4,462 & 2,550 & 5,764 & 3,014 & 2,370 \\
\hline Electricity Wholesaling & 4,802 & 6,398 & 5,865 & 8,241 & 6,823 \\
\hline \multicolumn{6}{|l|}{ Other Indirect Sources } \\
\hline Integrated Waste Services Association . . & -- & -- & -- & -- & 22,136 \\
\hline Others $\ldots \ldots \ldots \ldots \ldots \ldots$ & -52 & -352 & -850 & 1,002 & 1,363 \\
\hline Carbon Sequestration $\ldots \ldots \ldots \ldots \ldots$ & 71 & 391 & 419 & 452 & 766 \\
\hline \multicolumn{6}{|l|}{ Reported Total Reductions } \\
\hline Integrated Waste Services Association ... & -- & -- & -- & - & 22,136 \\
\hline Others $\ldots \ldots \ldots \ldots \ldots \ldots \ldots$ & 27,259 & 46,842 & 56,606 & 67,198 & 84,126 \\
\hline
\end{tabular}

*Less than 500 metric tons.

Note: "Reported Total Reductions" do not add to the sum of reported components due to differences in the accounting treatment of indirect emissions by various reporters, and because some reporters did not disaggregate their emissions reductions by category.

Source: Energy Information Administration, Form EIA-1605, "Voluntary Reporting of Greenhouse Gases," Schedule III.

Most companies submitting entity-level reports used modified reference cases. The most common arrangement was to assert that the collection of projects reported on Schedule II had reduced emissions compared with the case in which the projects had not been undertaken. All of the largest reductions claimed (Florida Power \& Light, Duke, and TVA) came from organizations that used a modified reference case, and all indicated that their reductions were the result of nuclear availability improvements and (in the case of Florida Power \& Light) shifting fossil generation from coal-fired steam turbines to gas-fired combined-cycle plants. Duke Power indicated that reductions came from changes in generation mix and from improved operation of three nuclear power plants.

Ten firms reported reductions using a basic reference case, comparing their emissions with their 1990 emissions or their emissions over a period of years. Table 18 illustrates the 1990 and 1995 carbon dioxide emissions for these firms. The claimed 1995 reductions for three reporters differed from the "difference" shown in Table 18. Public Service Electricity \& Gas used an average of 1987-1989 emissions, and Long Island Lighting Company and Northeast Utilities used a 1987-1990 average to calculate their "baseline." The carbon dioxide reductions claimed by these firms were $787,000,1,289,000$, and 1,073,000 metric tons respectively. DTE (formerly Detroit Edison) had emissions that were below 1990 levels through 1994, but which increased again when its nuclear power plant shut down in 1995.

\section{Treatment of Indirect Emissions}

The report from Public Service Electricity \& Gas (PSE\&G) illustrates the potential importance of the accounting treatment of indirect emissions from electric power transactions. PSE\&G's direct emissions declined between 1990 and 1995, but its indirect emissions from power purchases increased by a greater amount (Table 18).

Several reporters could have used the basic reference case to report emissions reductions by comparison with their 1990 emissions but elected not to do so. These firms included Johnson \& Johnson, Ohio Edison, and Pennsylvania Power \& Light, all claiming reductions that were considerably smaller than they might have claimed by using a basic reference case.

Table 19 illustrates reported emissions reductions for gases other than carbon dioxide. In general, the firms that reported emissions of gases other than carbon dioxide at the entity level tended to be very conservative about formally claiming reductions, even when their emissions declined. One of the largest claims of emissions reductions was by CONSOL, which made a very straightforward presentation: CONSOL's reported 1990 methane emissions from coal mining were 1.36 
Table 18. Reported 1990 and 1995 Carbon Dioxide Emissions for Selected Reporters Using a "Basic Reference Case"

(Thousand Metric Tons of Carbon Dioxide)

\begin{tabular}{|c|c|c|c|c|c|c|c|}
\hline \multirow[b]{2}{*}{ Reporter } & \multicolumn{3}{|c|}{1990} & \multicolumn{3}{|c|}{1995} & \multirow{2}{*}{$\begin{array}{l}\text { Difference } \\
\text { in Total } \\
\text { Emissions }\end{array}$} \\
\hline & Direct & Indirect & Total & Direct & Indirect & Total & \\
\hline Arizona Public Service Corporation & 13,898 & -- & 13,898 & 11,251 & -- & 11,251 & $-2,647$ \\
\hline "Central Hudson Electric and Gas & 7,337 & 257 & 7,594 & 3,726 & 985 & 4,711 & $-2,883$ \\
\hline DTE/Detroit Edison ......... & 39,637 & 5,696 & 45,333 & 41,511 & 5,112 & 46,622 & 1,289 \\
\hline Long Island Lighting Company . & 8,271 & 1,405 & 9,677 & 6,290 & 2,510 & 8,800 & -877 \\
\hline Los Angeles Department of Power and Water & 15,347 & 1,067 & 16,414 & 13,757 & 1,021 & 14,778 & $-1,636$ \\
\hline Niagara Mohawk Power Corporation & 15,157 & 3,605 & 18,762 & 8,254 & 7,068 & 15,322 & $-3,440$ \\
\hline Northeast Utilities & 10,587 & 1,987 & 12,574 & 7,775 & 2,477 & 10,251 & $-2,323$ \\
\hline Peabody Holding Company .... & 598 & 1,103 & 1,700 & 462 & 881 & 1,345 & -355 \\
\hline Potomac Electric Power Company & 19,546 & -- & 19,546 & 16,939 & -- & 16,939 & $-2,607$ \\
\hline Public Service Electric and Gas & 12,500 & 6,931 & 19,430 & 9,760 & 11,612 & 21,372 & 1,942 \\
\hline
\end{tabular}

Source: Energy Information Administration, Form EIA-1605, "Voluntary Reporting of Greenhouse Gases," Schedule III.

Table 19. Reported U.S. Entity-Level Emissions Reductions for Other Gases, 1991-1995 (Thousand Metric Tons of Gas)

\begin{tabular}{|c|c|c|c|c|c|}
\hline Gas & 1991 & 1992 & 1993 & 1994 & 1995 \\
\hline \multicolumn{6}{|l|}{ Methane } \\
\hline \multicolumn{6}{|l|}{ Direct Reductions } \\
\hline CONSOL & -- & 89,754 & 302,088 & 580,641 & 526,505 \\
\hline Others & 883 & 1,908 & 3,022 & 2,723 & 4,357 \\
\hline \multicolumn{6}{|l|}{ Indirect Reductions. } \\
\hline Integrated Waste Services Association . . & -- & -- & -- & -- & 907,185 \\
\hline Others $\ldots \ldots \ldots \ldots \ldots \ldots$ & 16,237 & 46,477 & 51,105 & 53,224 & 55,520 \\
\hline CFCs, HCFCs, and Solvents . . . . . . . . . & -- & -- & 3 & 7 & 12 \\
\hline HFC-134a & -- & -- & -- & -- & * \\
\hline Sulfur Hexafluoride $\ldots \ldots \ldots \ldots \ldots \ldots$ & -- & 5 & 5 & 5 & * \\
\hline
\end{tabular}

*Less than 500 metric tons.

Source: Energy Information Administration, Form EIA-1605, "Voluntary Reporting of Greenhoușe Gases," Schedule III.

million metric tons; its 1995 emissions were 0.84 million metric tons; thus, methane emissions were reduced by 0.53 million metric tons ( 3 million metric tons carbon equivalent). The other large reduction claim came from the Integrated Waste Services Association, which claimed that by burning waste that otherwise would have been landfilled, it reduced methane emissions from landfills by more than 900,000 metric tons (5.2 million metric tons carbon equivalent). Peabody Holdings also claimed a much smaller direct reduction of methane emissions from coal mining, using a modified reference case. Other indirect emissions reductions were claimed by several electric utilities, notably the New England Electric System and Cinergy, both of which reduced methane emissions by purchasing electric power generated from landfill methane projects.

\section{Foreign Emissions and Reductions}

In general, only incidental or marginal entity-level foreign emissions were reported. Most reporters with international operations defined their reporting entity as the U.S. operations of the firm. The principal exception was Dow Chemical, which reported on both U.S. and foreign operations. Other firms, including Baltimore Gas \& Electric, Cinergy, Duke Power, Florida Power \& Light, Illinois Power, Kansas City Power \& 
Light, the New England Electric System, Ohio Edison, Sierra Pacific, and Tampa Electric, reported emissions "offsets" from international forestry projects.

\section{Future Commitments}

In addition to collecting information on emissions and achieved reductions, the EIA also collects information on commitments to reduce emissions in the future, using Schedule IV of the reporting form (see Appendix A). Reporting on commitments to take future actions was not envisaged in the statutory language of the Energy Policy Act; however, during the development of the Voluntary Reporting of Greenhouse Gases Program, the Department of Energy asked the EIA to include a section in which reporters could voluntarily record future commitments.

Some 60 reporters (out of 142) used Schedule IV to record future commitments. The reporters making future commitments, without exception, were participants in various U.S. Government voluntary programs and used the Voluntary Reporting Program to reiterate formally commitments made under the program(s) in which they were participating.

In order to facilitate reporting, the EIA developed a taxonomy of reduction commitments:

- Entity commitments. As the name suggests, an entity commitment is a commitment by the reporter to reduce emissions or to sequester carbon on behalf of an entire organization. The essence of an entity commitment is that the reporter promises results, without necessarily specifying means. This year, 26 firms made 40 specific entity commitments.

- Entity financial commitment. In this instance, the reporter undertakes to spend a particular amount of money but does not necessarily commit the organization to the results of the expenditure. This year, 30 reporters made 61 financial commitments.

- Project commitment. In a project commitment, the reporter promises to undertake a particular action, without necessarily specifying the exact results of the action. This year, 39 firms made 252 project commitments.

As the figures above suggest, the reporters filing these forms typically made more than one type of commitment and usually mademore than a single cornmitment of each type.

\section{Entity Commitments}

Of the 26 entity commitments, 22 were made by electric utilities. (The nonutilities were Dow, DuPont, Noranda, and Alcan.) The commitments took diverse forms. Some of the more interesting entity commitments were:

- Florida Power \& Light promised to limit its emissions rate to the 1990 level of 1.38 pounds of carbon dioxide emitted for each kilowatthour sold. Pacificorp made a similar commitment, promising to reduce its emissions rate to 10 percent below 1990 levels.

- DuPont promised to reduce its GWP-weighted emissions of greenhouse gases by 40 percent compared with a 1991 baseline.

- Dow Chemical promised to reduce its emissions of certain "high toxic and ozone depleting chemicals 75 percent by $2005^{\prime \prime}$ from 1994 levels. The chemicals include all the common CFCs, certain HCFCs, carbon tetrachloride, methyl chloroform, and chloroform.

- Public Service Electricity \& Gas promised to reduce its entity emissions to 2.5 million tons below 19871990 average levels by 2000 . New England Electric Systems promised a 20-percent reduction below 1990 levels.

The most common entity commitment, however, was to reduce emissions by some specified amount below the utility's projected year 2000 emissions.

\section{Project Financial Commitments}

This year, 30 reporters made 61 financial commitments, totaling some $\$ 110$ million, of which about $\$ 10.5$ million was actually expended in 1995. Of the total amount, some $\$ 78$ million was committed (in 12 separate initiatives) by the Southern Company, including $\$ 46$ million for a single coal ash recycling project.

Twenty-seven of the thirty reporters were electric utilities. The nonutilities were Alcan, Noranda, and DeBourgh Manufacturing. Alcan and Noranda committed to an improvement in smelting technology that would reduce emissions of perfluorocarbons, and DeBourgh committed to spending money on highefficiency lighting, converting to powder painting, and reducing convection heat loss in manufacturing operations. 
Most electric utility financial commitments were connected with "mutual fund" type programs organized by the Edison Electric Institute. These included:

- The "UtiliTree" forest carbon management initiative (20 commitments)

- The "Envirotech" venture capital Fund (5 commitments)

- The "Earth Comfort" geothermal heat pump program (10 commitments).

In each, the Edison Electric Institute has organized and manages an investment pool, to which utility members are invited to contribute funds. The pool itself then invests in forestry projects (in the case of UtiliTree) or in energy efficiency or renewable energy technology (Envirotech) or geothermal heat pumps (Earth Comfort).

\section{Project Commitments}

The third form of commitment is a project commitment. In this instance, a reporter commits to undertaking a particular action. This year, 39 firms made 252 project commitments. Thirty-five of the firms were electric utilities. The nonutilities were Alcan, DeBourgh Manufacturing, Dow Chemical, and Noranda Aluminum.
Firms tended to use project-level commitments for two distinct purposes:

- To report on some of the estimated future consequence of projects already reported under Schedule II. Reporters indicated that 125 of the 252 project commitments were made with respect to the future performance of projects already listed. The largest emissions reductions promised from projects currently reported were by Tennessee Valley Authority (increase in low-emitting capacity) and Texas Utilities (availability improvements), both referring to nuclear power plants.

- To report on planned (but not yet implemented) projects. There were 127 such projects, many with specific reductions attached. The largest reduction promised for a new project was by Pennsylvania Power \& Light, which expects to reduce its direct emissions by 0.6 million tons and its indirect emissions by 3.6 million tons by upgrading its Susquehanna Station.

In a few cases, reporters tended to spread their commitments to undertake emissions reductions across categories. For example, NIPSCO reported its participation in the Edison Electric Institute's UtiliTree program as both a financial commitment and a project commitment. 



\section{Appendix A \\ The Voluntary Reporting Program: A Developmental Overview}

\section{Introduction}

Rising global atmospheric concentrations of carbon dioxide, methane, nitrous oxide, and other "greenhouse gases" have been a subject of increasing scientific and policy concern for the past decade. Many scientists and policymakers believe that increasing atmospheric concentrations of these gases (thought to be caused by human activities, particularly the combustion of fossil fuels) may cause significant long-term changes in global weather and climate by trapping more of the sun's heat within the atmosphere. The heat trapping properties of greenhouse gases are discussed in the box in Chapter 1 , page 6.

In 1992, President Bush signed a multilateral treaty, the Framework Convention on Climate Change, which committed the United States to take steps, in conjunction with other signatory states, to "... achieve ... stabilization of the greenhouse gas concentrations in the atmosphere at a level that would prevent dangerous anthropogenic interference with the climate system." 60

As the Framework Convention was being negotiated, the Congress began to consider measures that would help the U.S. Government develop the national "commitment" required by the treaty. One such measure was Section 1605(b) of the Energy Policy Act of 1992, which requires the Energy Information Administration (EIA) to create reporting forms and a database for the voluntary reporting of emissions and reductions in emissions of greenhouse gases.

The Voluntary Reporting Program was developed in a cooperative effort with potential reporters, the Department of Energy's Office of Policy, and the U.S. Environmental Protection Agency. The program permits individuals, corporations, and other organizations to report to the EIA on actions taken that have reduced emissions of greenhouse gases.

Reporters may choose to undertake the considerable effort of preparing their submissions for a variety of reasons, such as:

- To establish a public record of their voluntary contributions to achieving a national policy objective

- To provide the opportunity for others to benefit from their experience in reducing emissions

- To demonstrate their commitment to voluntary approaches to solving or ameliorating environmental conditions

- To record the activities undertaken pursuant to voluntary programs under the President's Climate Change Action Plan

- To create a presumption of "standing" in a possible future regulatory scheme to stabilize or reduce national emissions of greenhouse gases.

\section{Development of the Voluntary Reporting Program}

The Voluntary Reporting Program is required by Section 1605(b) of the Energy Policy Act of 1992 (see box in Chapter 1, page 2). More than 3 years elapsed from the passage of the law, in October 1992, to the completion of the first reporting cycle. The development of the Voluntary Reporting Program consisted of three phases:

- Guidelines development (October 1992 to October 1994)

- Forms development (February 1994 to July 1995)

- First report processing (July 1995 to March 1996).

\footnotetext{
${ }^{60}$ United Nations, "Report of the Intergovernmental Negotiating Committee for a Framework on Convention for Climate Change on the Work of the Second Part of its Fifth Session, Held at New York from 30 April to 9 May 1992," UN Document A/AC.237/18, Part II (May 15, 1992).
} 


\section{Guidelines Development}

The principal clauses of Section 1605(b) of the Energy Policy Act require the U.S. Department of Energy (DOE), in consultation with the U.S. Environmental Protection Agency (EPA), to issue guidelines for reporting emissions of greenhouse gases. The EIA was then required to develop a reporting framework consistent with the guidelines. The information collected was to be accessible for public use.

The development of the guidelines was assigned to DOE's Office of Policy, which began a series of public workshops to gather information about public expectations of the program. The public workshops on the guidelines ran from September 1993 to March 1994 and were held in Washington, DC, Atlanta, GA, and Chicago, IL. The workshops spanned a range of issues relating to the objectives of the Voluntary Reporting Program, the definition of a "credible" report, and methods of reporting.

On April 21, 1993 (Earth Day), President Clinton committed the United States to stabilizing its emissions of greenhouse gases at 1990 levels by the year 2000. The methods by which the Government proposes to achieve this objective were described in the President's Climate Change Action Plan, published in October 1993.61 That document spells out a range of largely voluntary programs intended to limit emissions of greenhouse gases. Readers may also wish to consult the Action Plan's Technical Supplement, published in early 1994, which describes the assumptions underlying the Plan in greater detail. ${ }^{62}$

Differing notions of the purpose of the Voluntary Reporting Program were expressed, as well as differing views about the nature and type of information to be collected. Many potential reporters tended to stress the notion that the reporting system should be "simple and flexible." They typically opposed suggestions to construct detailed "official" definitions of baselines, reporting entities, and coverage of reports. It was argued that such definitions were premature in an experimental program, would discourage companies from reporting, and would render the program relatively narrow.

Some commenters argued the reverse. They urged explicit and specific definitions of "who is responsible for an emission." The individuals and organizations holding these views hoped to elicit reports that revealed absolute and verifiable emissions reductions.

Following the workshops, a public review draft of the guidelines was published in May 1994. After further public comment, final guidelines were published in October $1994 .^{63}$

The guidelines contain several broad themes that have shaped the program:

- The Department held that the primary objective of the program was "broad participation." Any U.S. "legal person" (i.e., individual, corporation, trade association, or private voluntary organization) may report.

- Within the confines of the statute, reporters were given nearly complete flexibility in crafting their reports. Reporters were free to define as they saw fit the nature of the reporting entity, the emissions and reductions to be reported, methods of calculating emissions and reductions, and the type of activity deemed to cause emissions reductions.

- Reporters were to be permitted to report on activities both in the United States and abroad, so long as they distinguish between domestic and foreign activities.

- Reporters were to be encouraged to report both emissions and emissions reductions as comprehensively as possible, accounting for both "direct" and "indirect" emissions, and also for "primary" and "secondary" effects. These terms are further defined below.

- Reporters were to be encouraged to report on emissions and emissions reductions for a range of greenhouse gases.

- Reporters were to be permitted to report "achieved reductions," defined as emissions reductions achieved since 1990.

The guidelines did not define "property rights" in emissions. For example, the emissions from generating electricity could be the responsibility of an electric utility or the purchaser of the electricity. By accepting the validity of differing possible interpretations of who "owns" emissions, reporters were given considerable

\footnotetext{
${ }^{61}$ President William J. Clinton, The Climate Change Action Plan (Washington, DC, October 1993), p. i.

${ }^{62}$ U.S. Department of Energy, The Climate Change Action Plan: Technical Supplement, DOE/PO-0011 (Washington DC, March 1994).

${ }^{63}$ U.S. Department of Energy, Voluntary Reporting of Greenhouse Gases Under Section 1605(b) of the Energy Policy Act of 1992: General Guidelines, and Sector-Specific Issues and Reporting Methodologies Supporting the General Guidelines for the Voluntary Reporting of Greenhouse Gases Under Section 1605(b) of the Energy Policy Act of 1992, Volumes 1 and 2, DOE/PO-0028 (Washington, DC, October 1994).
} 
flexibility in reporting on their greenhouse gas emissions and emissions reduction activities. The guidelines explicitly recognized the possibility that, in the absence of clear "property rights," two or more organizations might report on the same emissions reduction activity, an eventuality called "double reporting." The flexibility of the guidelines has, of necessity, resulted in a relatively complex reporting form and database.

\section{Forms Development}

The EIA developed, in parallel, reporting forms and a database consistent with the guidelines. In early November 1994, 2 weeks after the issuance of the final guidelines, the EIA issued draft forms for public review. The draft forms were pre-tested by several firms interested in reporting, including Niagara Mohawk Power, Houston Light \& Power, and General Motors. Many useful comments were received, both from pre-testers and from the public review process.

Following the public review, the EIA sent the forms to the Office of Management and Budget (OMB) for formal clearance under the Paperwork Reduction Act, a legal requirement for any Federal data collection exercise. The OMB requested further public comment and, after reviewing the forms, cleared them for public use in May 1995. After final editing and layout revisions to enhance readability, the EIA released the forms to the public in July 1995.

\section{The Voluntary Reporting Program and the Climate Change Action Plan}

As the President's Climate Change Action Plan got underway, managers of certain DOE- and EPAsponsored voluntary emissions reduction programs (as well as some participants) felt the need for a reporting system to record and describe the actions of participants in those programs. The 1605(b) Voluntary Reporting Program, already underway with an OMBapproved data collection instrument and a requirement to collect information about a broad range of emissions reduction activities, turned out to be a useful vehicle for recording results of the voluntary reduction programs. Participants in the "Climate Challenge" program (for electric utilities) and the "Climate Wise" program (for manufacturing firms) are strongly encouraged to file reports documenting their emissions reduction efforts with the Voluntary Reporting Program. ${ }^{64}$

\section{Forms Design}

The data collection forms for the Voluntary Reporting Program, as developed, endeavor to cover the complexity in categories of emissions required by the guidelines. To this end, the structure of the voluntary reporting database needed to be expansible to cover many different contingencies, including the following:

- Reporters ranged from some of the largest industrial firms in the United States to individual households and voluntary organizations.

- Reporters could report on particular actions they had taken to reduce emissions or on the emissions (and reductions) of their entire organizations.

- The statute required, and reporters requested, the ability to report on many different classes of actions that have the effect of reducing greenhouse gas emissions, ranging from energy conservation to carbon sequestration.

- The reporting format seeks to identify areas where multiple reporting of the same project actually occurs, and to make possible a general assessment of the reliability and possible ownership of the reports.

- The lack of generally accepted accounting principles for greenhouse gas emissions requires a design that permits a variety of reporting formats. This led to ambiguities that the forms design tried to clarify.

- The guidelines permit the reporting of foreign emissions reduction actions.

- The guidelines permit reporting on reductions for a range of greenhouse gases.

- Managers of voluntary programs asked the EIA to develop a mechanism for collecting participants' commitments to reduce future emissions.

The EIA developed two alternative reporting instruments: the long form (Form EIA-1605), which comprises four schedules (described in the box on page 74), and the short form (Form EIA-1605EZ). The short form is intended to cover reporting solely on emissions reduction projects and for a single year only.

The text box on page 74 outlines the basic structure of the long form. The form has four schedules. The first schedule simply asks for the name and address of the

\footnotetext{
${ }^{64}$ Not all participants in those programs have filed 1605 (b) reports. Many participants have promised to take actions in the future, which will not be reportable until the actions have produced results. Section $1605(\mathrm{~b})$ obliges the EIA to receive reports of "achieved reductions," meaning the results of actions already taken. Further, many participants joined the voluntary programs after the close of the 1995 reporting cycle. Finally, some voluntary program participants may have experienced difficulty in gathering together the necessary information to file their reports.
} 


\section{The Structure of Form EIA-1605}

\section{Schedule I. General Information}

This schedule asks for the reporter's name, address, and type of entity, and whether the report contains confidential information.

\section{Schedule II. Project Level Emissions and Reductions}

This schedule covers reporting of specific actions that the reporter has taken that have reduced emissions. It is divided into ten parts, each covering a specific type of project. Each part requests general information about the location and nature of the project, emissions, emissions reductions, and (if applicable) fuel or energy savings. Each part also asks a number of questions specific to the project type that will enhance the ability of data users to assess the emissions reductions claimed.

Section 1 Electric Power Generation, Transmission, and Distribution

Section 2 Cogeneration

Section 3 Energy End Use
Section 4 Transportation and Off-Road Vehicles

Section 5 Waste Treatment and Disposal-Methane

Section 6 Agriculture-Methane and Nitrous Oxide

Section 7 Oil and Natural Gas Systems and Coal Mining-Methane

Section 8 Carbon Sequestration

Section 9 Halogenated Substances

Section 10 Other Projects

\section{Schedule III. Entity Level Emissions and Reductions}

This schedule covers reporting on the emissions of an entire entity. It requests direct and indirect emissions, reductions in direct and indirect emissions, carbon sequestered, and total emissions reductions.

\section{Schedule IV. Commitments to Emissions Reduction or Sequestration Projects}

This schedule permits reporters to outline commitments to reduce emissions in the future, generally as part of a Government-sponsored voluntary program. reporter, along with some particulars about the report. The most fundamental distinction is between "project reporting" in Schedule II, and "entity reporting" in Schedule III. Project reporters are reporting on specific actions they have taken to reduce emissions. Entity reporters are reporting on emissions and emissions reductions for an entire organization. For example, during the second reporting cycle of the Voluntary Reporting Program (1996 reporting year), 51 reporters provided entity-level reports, and 129 reporters provided project-level reports. Thirty-nine reporters filed both entity-level and project-level reports, while 13 reporters filed only entity-level reports. Within Schedule II, the report is further subdivided into ten sections, reflecting the diversity of anticipated reduction actions. Each section contains general questions that are applicable to all ten sections, as well as other questions which are specific to the particular type of project, to help reporters and the EIA understand and describe the project.

In order to clarify what reporters are claiming as "their" emissions, the voluntary reporting system generally distinguishes between "direct" and "indirect" emissions. A direct emission is defined as an emission from a facility owned by a reporter, while an indirect emission is defined as an emission from a facility owned by someone else, but for whose emissions the reporter deems himself to be responsible.

Schedule IV was added to assist participants in DOEand EPA-sponsored voluntary programs in recording their commitments to reduce future emissions. Fortytwo firms reported on Schedule IV. All Schedule IV reporters were electric utilities, and all were participants in the "Climate Challenge" program. 


\section{Appendix B Emissions Accounting Issues}

\section{Introduction}

The Department of Energy's guidelines for the Voluntary Reporting Program generally took the view that it was for reporters themselves to define the emissions and reductions for which they felt themselves responsible. However, it was the task of the Energy Information Administration (EIA) to develop a reporting system in which these possibly diverse definitions could be made clear to data users. In attempting to achieve this objective, the EIA was able to identify a number of emissions accounting issues that presented significant problems in understanding and interpreting the data.

This appendix discusses several important issues in the development of the forms and the review of incoming reports. This work may assist data users in understanding the uses and limitations of data from the Voluntary Reporting Program.

\section{The Nature of the Entity}

As noted in Chapter 8 of this report, there are different views about the nature of the entity, and reporters have adopted various conventions. In general, the most common definition of the entity is a corporation. However, reporters have made a number of modifications to this concept; for example, General Motors excluded its overseas operations and its interest in Electronic Data Systems (EDS) from its definition of its corporate entity. Most electric utilities defined their entities as their regulated utility activities, excluding unrelated activities owned by their holding companies. Houston Light \& Power excluded the activities of its parent company, Houston Industries, which include a cable TV operation.

Not all entities are firms. Several reporters are facilities, notably, Alcan's Sebree Aluminum Plant, which reduced emissions of perfluorocarbons. Several firms reported projects which they undertook on behalf of some other organization, such as landfill methane capture or tree planting, where the owner of the project was not necessarily the reporter. This led to several instances of multiple reporting.

\section{Types of Reports}

The language of the statute calls for reporting of "annual reductions of greenhouse gas emissions ... achieved through any measures ..." $(1605(\mathrm{~b})(1)(\mathrm{B}))$, and separately calls for "an aggregate calculation of greenhouse gas emissions by each reporting entity." As interpreted in the guidelines and in the forms, it establishes two categories of reporting of emissions reduction:

- In an "entity-wide" report, the emissions reported are the emissions of the entire entity: for example, the total emissions of a particular electric utility. The emissions of the entity can rise or fall. Some firms (6) did not report emissions reductions but simply reported emissions.

- In a "project report," the reporter indicates the results of certain specified actions taken (called "projects") that resulted in a reduction of emissions of greenhouse gases (or increased sequestration). Most firms that filed entity-wide reports also filed one or more reports on projects.

\section{Emissions and Reductions}

The distinction between reporting emissions and reporting emissions reductions is fundamental to the Voluntary Reporting Program. The program, following the language of the statute, asks for both emissions and reductions. At the entity level, the definition of emissions is relatively straightforward. At the project level, however, the definitions of emissions and reductions can be intricate. The fundamental problem is that the project may be only a piece of a larger system, and it is not clear whether "emissions and reductions" refer to the emissions of the part or the emissions of the whole system.

In some cases, a project may not have meaningful emissions at all. For example, large electric utilities have multiple power generation plants that are used, as a group, to generate electricity. Since electricity consumption varies from moment to moment-depending on the season, weather, time of day, and whims of thousands or millions of customers-utilities operate dispatch 
centers that continually choose the least-cost generation mix to actually dispatch at a particular moment in time. At any given time, some plants may be on "spinning reserve," some are generating power, others may be on standby, and others may be shut down for maintenance. All available generation units are ranked by "merit order" (some combination of short-run marginal cost and operational considerations) and are used in order of increasing "merit," with the lowest cost units used first, subject to availability. Momentary surpluses of electricity may be sold to others, and shortages may be made up by purchases from others.

Suppose a large utility replaces an old, low-efficiency fossil plant with a new, high-efficiency plant. In principle, the new plant could affect the usage (and hence emissions) of every other plant on the utility's system, and even on other utility systems, since the new unit will "bump" all higher cost units in the merit order. Thus, the relevant emissions that are being reduced by the project are the emissions of the entire system, and the actual emissions of the new plant may be much higher than the emissions of the old unit. Since the old unit was a high-cost unit, it may have been used only occasionally. The new unit, with low costs, will be dispatched frequently and will displace the emissions not of the unit it replaced, but of other units with costs greater than the new unit but lower than the old unit.

Some utility reporters chose to define their emissions as all of their power generation emissions. Other utilities defined their emissions as the emissions of a particular plant. While both definitions are reasonable, they are not comparable.

\section{Direct and Indirect Emissions and Reductions}

One of the more contentious issues that emerged in the process of developing the guidelines was the question of defining exactly who was responsible for particular emissions. Suppose, for example, in response to an EPA initiative, that a refrigerator manufacturer designs and builds an energy-efficient refrigerator with performance that far exceeds that of other refrigerators on the market. An electric utility then offers rebates to customers if they purchase the energy-efficient refrigerator. Customers buy the refrigerator and accept the rebate. The customers purchase less electricity, and the electric utility generates (or purchases) less electricity from fossil fuels, thus reducing emissions. But who is "responsible" for this reduction, and on what grounds?
- Government (for sponsoring the initiative)?

- The refrigerator manufacturer (for building the refrigerator)?

- The refrigerator dealer (for choosing to buy and carry the efficient model in preference to some other model)?

- The electric utility (for offering the rebate)?

- The customer (for choosing to buy the refrigerator)?

- The customer (for purchasing less electricity)?

- The electric utility (for burning less fuel)?

- Some other electric utility (for burning less fuel, as a consequence of selling less electricity to the customer's utility)?

There is no perfect answer to this question. All the participants have some influence on the eventual outcome. Further, "responsibility" can have multiple meanings. Will a firm be made legally responsible for the emissions in some hypothesized future regulatory environment? Or, alternatively, who gets "recognition" for taking an action that reduces emissions?

In addition, different observers could choose a particular responsible party for different reasons, which means that they might agree on this example and disagree on some other example. Some might view the payment of the rebate as the "act" that makes the utility the "responsible" party. Others might view the utility as the responsible party because it was the utility whose emissions actually declined.

The guidelines, in accordance with legislative provisions and the objective of broad participation, do not assign the "right" to report emissions or reductions. Thus, in the Voluntary Reporting Program, all the participants in the hypothetical transaction described can justifiably report on an action to reduce emissions, since ownership in this case is not exclusive.

This decision created, not surprisingly, second-order problems for the design of the reporting system. The two largest problems were:

- Multiple entities could report on the same project, a contingency dubbed "multiple reporting."

- Since reporters' definitions of "their" emissions and reductions are, in principle, restricted only by the reporters' (possibly inclusive) notions of the nature of causation, it could be very difficult to determine the actual origin of the claimed emissions and reductions. 
The design of the Voluntary Reporting Program took several steps to identify instances of multiple reporting and to clarify reporters' definitions of emissions. To clarify instances of multiple reporting, project-level reporters are asked whether other entities might be reporting on the same activity and, if so, who. Reporters are also asked about joint-venture partners (if any) for projects, which helps to identify a particular class of multiple reporting with precision.

In order to clarify the reporters' definitions of "ownership" of emissions, the guidelines define (and the forms implement) the concept of "direct" and "indirect" emissions. A "direct" emission is an emission from a source owned and controlled by the reporter. If you drive a car, the emissions from the tailpipe of your car are direct emissions (for you). "Indirect" emissions are emissions that the reporter in some sense "caused" to occur, although the reporter did not own or control the facility producing the emission.

Direct emissions correspond to the most restrictive, and most intuitive, sense of "ownership" of emissions. Indirect emissions account for less restrictive definitions of ownership or responsibility. The Voluntary Reporting Program requires reporters to distinguish between "direct" and "indirect" emissions, and this distinction has proved useful in understanding reporters' definitions of "ownership."

In practice, with a few exceptions, reporters tended to have very straightforward and intuitive definitions of "their" emissions and "their" reductions; however, these straightforward and intuitive definitions were not always consistent across reporters. Nearly everyone tended to accept the notion that direct emissions and reductions belong to the owner of the source producing the emissions. Thus, if a reporter owns and operates a fossil fuel power plant, usually the reporter is viewed as being responsible for the emissions of the plant.

In the case of sales of electricity, views were much more diverse. Electricity consumers, such as households and manufacturing firms, tended to view themselves as responsible for indirect emissions arising from their use of electricity. On the other hand, electric utilities also tended to view themselves as responsible for their customers' use of electricity.

Reporters accounted for wholesale electricity transactions in various ways:

- Distribution-only electric utilities tended to behave like end-use consumers, and to view themselves as responsible for the electricity consumption of their customers and, hence, for the indirect emissions of their suppliers.
- Electric utilities that both bought and sold electricity had diverse views: some utilities assumed responsibility only for their direct emissions (i.e., sales to wholesale and retail customers, but no responsibility for electricity purchases).

- Other utilities added direct emissions to wholesale purchases but did not deduct wholesale sales. (This is the approach recommended in the instructions.)

- Still others summed their purchases and wholesale sales of electricity to calculate "net" indirect emissions as an addition to direct emissions.

Each approach produces a different figure for the total emissions of the reporter, and there is no theoretical basis for defining one approach as "correct." Each approach has conceptual and practical merits and drawbacks, depending on the intended purpose of the calculation and the circumstances of the particular reporter.

In general, the treatment of wholesale power transactions is important only for those electric utilities that (a) have large wholesale power sales relative to generation and retail sales (if the number is small, it matters little what accounting convention one follows); (b) have large changes in the level of wholesale power sales (if the number does not change much, it will not affect reductions); and (c) are using a "basic" reference case (if the reduction is defined as the outcome of a set of actions, the level of wholesale power transactions will not affect the magnitude of the reduction).

The importance of wholesale power transactions is likely to grow in the near future, however, since it is probable that pending changes in transmission access regulations will greatly increase the amount of electric power that is traded among utilities in the United States. In the absence of a common definition of responsibility for wholesale transactions, it will be increasingly difficult to compare reports from different utilities without a careful study of the underlying assumptions.

\section{Reporting Fuel Cycle Effects}

"Primary effects" and "secondary effects" are terms that are defined in the guidelines. The guidelines were concerned with the notion that reporters could claim reductions from actions that might produce much larger emissions elsewhere. This notion is linked to the concept of fuel cycle effects. As an example, a reporter claims to have reduced emissions by replacing his gasoline-powered automobile with an electric automobile. The primary effect is the direct reduction in emissions from the reduction in burning gasoline. Most 
reporters would consider the increased electricity consumption due to the electric automobile to be a primary effect as well, though an indirect emission.

There are also other (secondary) effects that one might wish to consider. Mining additional coal and producing additional natural gas causes additional emissions of methane. Reducing gasoline consumption also reduces emissions from oil refining and methane emissions from crude oil and gasoline transportation and storage, a positive secondary effect.

Primary and secondary effects are loosely related to direct and indirect emissions. Direct emissions reductions are generally the primary effect. Indirect emissions reductions may be a primary or a secondary effect, but the secondary effects almost always cause indirect emissions.

Despite the amount of space given to primary and secondary effects in the guidelines, reporters almost universally ignored secondary effects (whether positive or negative) in their reporting. When queried about this point, reporters tended to argue that they had no basis for estimating secondary effects, which would require "certifying the accuracy" of an estimate of emissions from other industries remote in space and time from the reporter's knowledge and concern.

\section{The Nature of the Reference Case}

The emphasis of the Voluntary Reporting Program is on reporting reductions in emissions. However, the development of the guidelines raised the question: reductions compared to what? The guidelines developed the notion that a "reduction" in emissions is defined by comparison with an alternative situation. This alternative situation was called a "reference case." The guidelines defined two ways in which a reference case could be defined: "basic" and "modified."

A basic reference case is the most straightforward. A basic reference case is the reporter's level of emissions at some period in the recent past: for example, the reporter's emissions in the year 1990. This definition is closest to the definitions implicit in the Framework Convention and those used in the Clean Air Act emissions trading scheme. If the reporter's emissions today are less than they were in 1990, then the size of the reporter's reduction is equal to the difference between current emissions and 1990 emissions.

Basic reference cases are most meaningful in the context of entity-wide emissions. When applied to specific projects, however, a basic reference case can often become ambiguous or meaningless. For example, suppose an electric utility offers a program to induce homebuilders to add more energy-efficient appliances to newly constructed houses. The new appliances will consume less energy in the future than some alternative device, but there are no baseline historic emissions. Any new project that is not an exact, one-for-one replacement for an old project faces a similar problem. It is useful to recall that one of the purposes of the Voluntary Reporting Program is to recognize and encourage actions that tend to reduce greenhouse gas emissions, whether they are new or existing sources.

In the Voluntary Reporting Program, therefore, a second method of calculating reductions is provided: the "modified reference case." A modified reference case is, in effect, a hypothetical case: the notion is that a reporter's emissions would have been higher, had he not taken certain actions. In the case of the electric utility, the "modified reference case" would be the putative emissions of the new houses with the appliances that homebuilders would have chosen without the intervention of the electric utility, and the reduction would be the difference between emissions with the energy-efficient appliances and emissions with "typical" appliances.

Modified reference cases always have a degree of uncertainty about them, since it is never possible to be absolutely certain about what would have happened in the absence of a particular action. By providing modified reference cases, the guidelines permitted the reporting of an extensive range of important and interesting projects. In practice, most project reports used various forms of a modified reference case. About twothirds of entity-wide reporters also used a modified reference case, indicating that while emissions increased, they did not increase as much as they would have increased in the absence of actions by the reporter.

\section{Mergers and Acquisitions}

The definition of reference cases for measuring reductions presupposes that the definition of the entity itself remains stable over time. This is not always the case. Firms can merge, buy and sell assets, expand, shrink, or even go out of business altogether.

When this occurs, the basis for comparing past emissions with present emissions becomes more complex, as . in the following examples of measurement issues:

- In 1990, Pacificorp purchased certain coal-fired power plants from Arizona Public Service Corporation. Pacificorp initially considered incorporating the emissions of these plants prior to 1990 in order to provide a profile of emissions from a consistent 
set of facilities. Arizona Public Service wished to include the pre-1990 emissions of these plants in their emissions profile as well. Ultimately, Pacificorp decided not to report pre-1990 emissions from the plant.

- When two reporters merge, the newly formed firm will probably file a single report. Merging the historical emissions of the two firms produces a nonhistorical reference case, though it is a logical basis for comparison with current and future emissions.

In general there are three approaches to an entity that is changing shape over time. One can either accept that a changing entity will produce changing emissions and report the results, or one can restate historical emissions "as if" the new entity had always existed. Finally, one can restate current emissions "as if" the older form of the entity existed today.

The CONSOL Coal Group chose the latter approach in this year's report. CONSOL reported emissions estimates for 1990, 1994, and 1995 based on recorded measurements where possible and best estimates if measurements were unavailable. In 1993, CONSOL acquired Island Creek Coal Company, whose mines are located in a very gassy coal seam in Buchanan County, Virginia. Parallel to the financial accounting of mergers, acquisitions, and divestment guided by standard accounting practices, CONSOL has "restated" 1990 emissions to include those emissions from acquired Island Creek mines.

In general, each of these approaches will have its merits in particular situations. In many cases, however, the problem will be best dealt with by properly accounting for changes in indirect emissions. For example, if a utility signs a power purchase agreement with an independent power producer (IPP), in principle it is outsourcing its power generation, and a reduction in direct emissions (from the utility's own capacity) is offset by an increase in indirect emissions (from the IPP).

\section{Domestic and Foreign Actions}

Reporters are permitted to file reports on actions both within the United States and abroad, but they are required to distinguish between domestic and foreign emissions and reductions and report them separately. The rationale for this distinction is that, on the one hand, the President's commitment under the Framework Convention is to reduce domestic emissions. Therefore, only domestic emissions "count" in achieving the President's commitment. On the other hand, it has long been an objective of U.S. climate change policy to promote "joint implementation," wherein one coun- try participates in emissions reduction projects in another country. Further, since greenhouse gas emissions have equal consequences no matter where the source of the emissions is located, foreign reductions are just as valuable as domestic reductions in ameliorating climate change. Therefore, both kinds of report are permitted, while the distinction between domestic and foreign reports is preserved. In practice, only a relatively small number of reports were received relating to projects or activities abroad, largely forestry projects.

\section{Confidentiality}

Section 1605(b)(3) requires the Energy Information Administration to offer protection from publication and Freedom of Information Act requests to reporters who are submitting trade secret and commercial or financial information. In practice, for most firms wishing to participate in a public, voluntary program, one of whose benefits is public recognition of their actions, confidentiality is unnecessary. Firms worried about proprietary data can refrain from reporting, or design their reporting definitions to protect proprietary data. In 1996, only two firms requested confidentiality. Their reports are not included in the release of the Public Use Database.

\section{Emissions Trading}

One of the most striking uses of a voluntary report occurred when Niagara Mohawk Power Corporation and the Arizona Public Service Company engineered the first-ever trade of carbon dioxide emissions reductions. Arizona Public Service Company agreed to trade 20,000 sulfur dioxide allowances (obtained under the Clean Air Act Amendments) in exchange for rights to 2.25 million metric tons of carbon dioxide emissions reductions achieved by Niagara Mohawk in the period 1991 through 1993. This exchange was expected to have taken place by December 31, 1996. Niagara Mohawk indicated its intent to donate the sulfur dioxide allowances to a nonprofit environmental organization, which would then cancel the sulfur allowances. Niagara Mohawk also indicated that it intended to use the tax benefits associated with the donation to fund additional greenhouse gas emissions reduction projects.

\section{Data Validation and Accuracy}

Section 1605(b) of the Energy Policy Act requires the Secretary of Energy to issue guidelines that "establish procedures for the accurate voluntary reporting of greenhouse gases." During the development of the 
Voluntary Reporting Program, there was considerable discussion of the related topics of "data validation" and "data accuracy." Some observers, who were concerned about the accuracy of emissions reporting, recommended "third-party validation," meaning, in essence, reviews or audits of reporting by disinterested third parties. The law also states: "Persons reporting under this subsection shall certify the accuracy of the information reported." That sentence has been interpreted to mean that it is the reporter who is responsible for the accuracy and correctness of the emissions and reductions claimed in the Voluntary Reporting Program.

The EIA devotes considerable effort to the review of incoming reports. Each report is assigned to an EIA reviewer, who reviews the reported information for internal consistency, accuracy of calculation, and comparability with other sources of information. The reviewer then prepares a list of issues for discussion with the reporter, who is asked about possible problem areas identified in the review. In some cases, reporters subsequently chose to revise their reports. All of the information described in this document is the product of that review' process.

This work has given EIA useful insights into the potential and limitations of data validation and accuracy. First, nothing in the review process gave the slightest credence to the notion that reporters deliberately prepared and submitted inaccurate voluntary reports. Reporters found the task of developing emissions and reductions estimates sufficiently daunting in itself. The notion of deliberately inaccurate reporting has tended to divert attention from the genuine problems faced by reporters in attempting to prepare accurate reports. Some of those real problems include:

- Lack of generally accepted "accounting standards" for emissions. This left each reporter to make judgments about the limits of the reporting entity and the ownership of emissions. Most reports were clear about the judgments that had been made, but it still can be difficult to aggregate and compare reports.

- Imprecision in estimation methods. Emissions of greenhouse gases generally are estimated on the basis of operating data, particularly, consumption of fossil fuels. Estimates of direct emissions from the combustion of fossil fuels should be reasonably accurate; however, there are significant uncertainties inherent in the estimation of indirect emissions generally, as well as in the estimation of emissions (direct or indirect) of other gases (particularly, methane and nitrous oxide). Many reporters chose not to report indirect emissions or emissions of other gases because of those uncertainties.

- Limited expertise in emissions estimation. Organizations rarely collect information on greenhouse gas emissions, and they have no reason to develop corporate expertise in estimating emissions. Reporters must start from scratch in collecting underlying operating data and developing expertise in estimating emissions on the basis of operating data.

- Limited availability of data within the organization. A comprehensive emissions and reductions report might cover direct combustion of fossil fuels, electricity purchases, use of halogenated substances as refrigerants and solvents, consumption of transportation fuels (gasoline and diesel), and any process emissions peculiar to the reporter. Collecting such information within an organization can present significant challenges, particularly for manufacturing companies, where energy is a relatively small portion of total operating costs. Companies may not collect fuel, electricity, or refrigerant consumption data at all, and many companies may record financial (but not quantitative) data in their accounting systems. Alternatively, the information may be collected only at the local (plant) level and never forwarded to corporate headquarters. In such cases, the person preparing the report must obtain information from a host of individual plant managers. Personnel in separately managed subsidiaries may be unable or unwilling to provide information. While current data may be available, historical data may be destroyed, archived, or otherwise practically unrecoverable.

These considerations have shaped the reports submitted to the Voluntary Reporting Program. Reporters have tended to calculate emissions where data are available, to make the calculations they can make, and to form reasonable judgments about what information they should meaningfully include. 


\section{Appendix C Summary of Reports Received}

Table C1. 1995 Reporting Entities

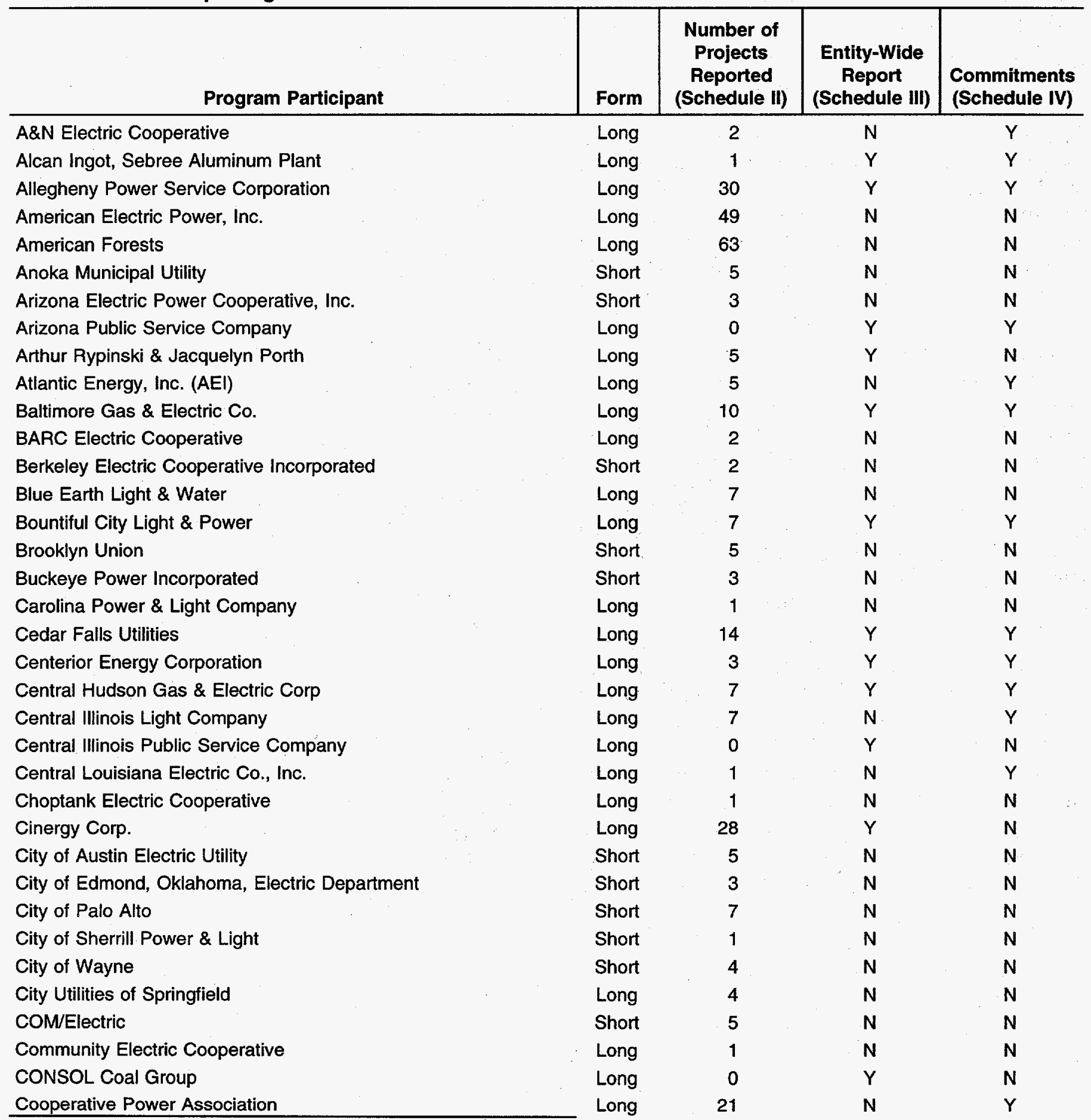




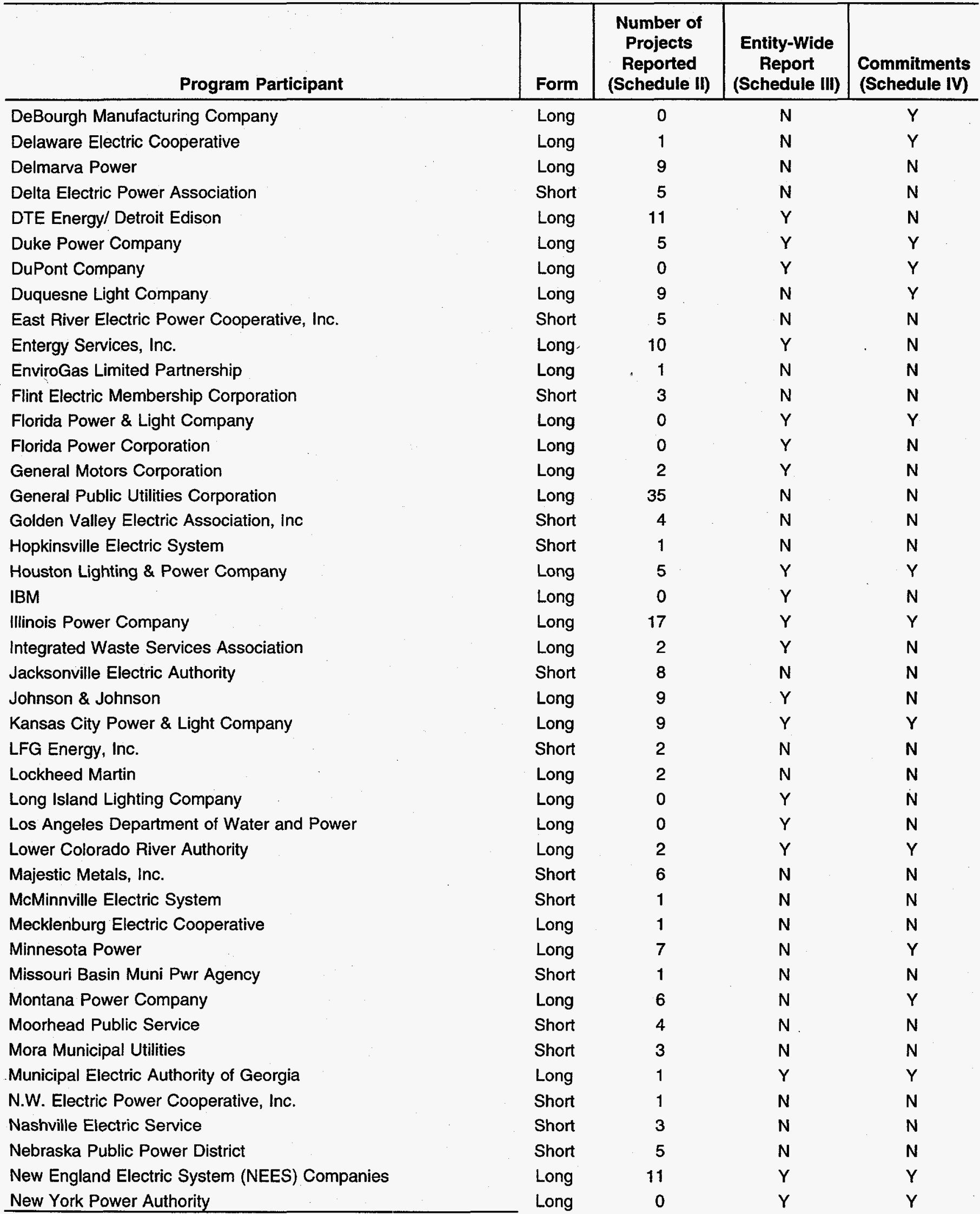




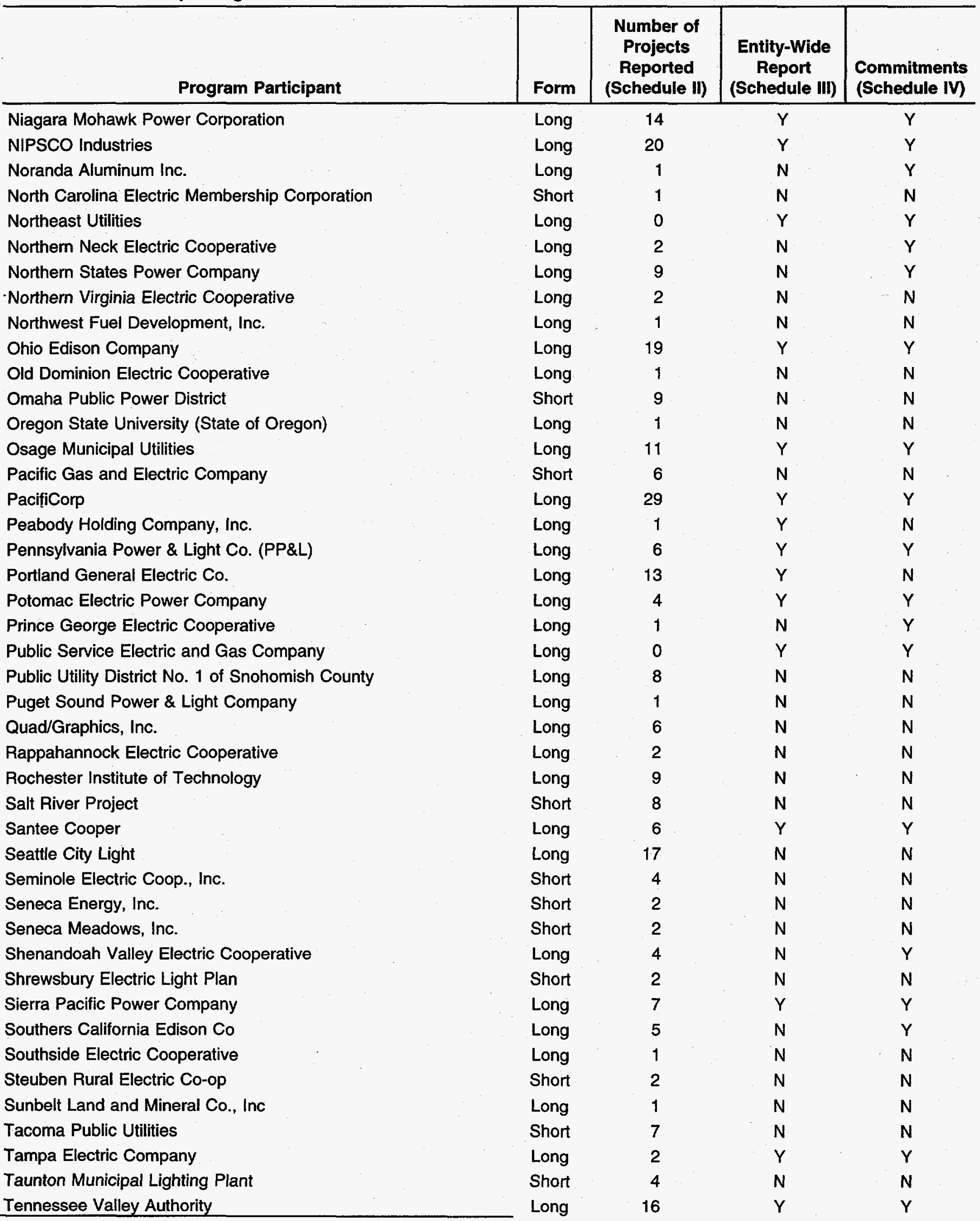




\begin{tabular}{l|c|c|c|c}
\hline \multicolumn{1}{c|}{ Program Participant } & Form & $\begin{array}{c}\text { Number of } \\
\text { Projects } \\
\text { Reported } \\
\text { (Schedule II) }\end{array}$ & $\begin{array}{c}\text { Entity-Wide } \\
\text { Report } \\
\text { (Schedule III) }\end{array}$ & $\begin{array}{c}\text { Commitments } \\
\text { (Schedule IV) }\end{array}$ \\
\hline Texas Utilities Electric Company & Long & 9 & $\mathrm{~N}$ & $\mathrm{Y}$ \\
The Dow Chemical Company & Long & 2 & $\mathrm{Y}$ & $\mathrm{Y}$ \\
The Southern Company & Long & 11 & $\mathrm{Y}$ & $\mathrm{Y}$ \\
Trees for the Future & Long & 13 & $\mathrm{~N}$ & $\mathrm{~N}$ \\
Tucson Electric Power Company & Long & 8 & $\mathrm{~N}$ & $\mathrm{Y}$ \\
UNICOM (Commonwealth Edison Company) & Long & 8 & $\mathrm{~N}$ & $\mathrm{Y}$ \\
Union Electric Company & Long & 18 & $\mathrm{~N}$ & $\mathrm{Y}$ \\
United Power Association & Long & 8 & $\mathrm{~N}$ & $\mathrm{Y}$ \\
Utah Municipal Power Agency & Short & 4 & $\mathrm{~N}$ & $\mathrm{~N}$ \\
Vermont Public Power Supply Authority & Long & 12 & $\mathrm{~N}$ & $\mathrm{~N}$ \\
Waverly Light \& Power Company & Long & 9 & $\mathrm{Y}$ & $\mathrm{Y}$ \\
Western Resources, Inc. & Long & 26 & $\mathrm{~N}$ & $\mathrm{Y}$ \\
Wisconsin Electric Power Co. & Long & 9 & $\mathrm{~N}$ & $\mathrm{Y}$ \\
Wisconsin Power \& Light & Long & 16 & $\mathrm{Y}$ & $\mathrm{Y}$ \\
Wisconsin Public Power Inc. & Short & 12 & $\mathrm{~N}$ & $\mathrm{~N}$ \\
Wisconsin Public Service Corporation & Long & 3 & $\mathrm{Y}$ & $\mathrm{Y}$ \\
Zahren Alternative Power Corp. & Short & 10 & $\mathrm{~N}$ & $\mathrm{~N}$ \\
Zeeland Board of Public Works & Short & 3 & $\mathrm{~N}$ & $\mathrm{~N}$ \\
\hline
\end{tabular}




\begin{tabular}{|c|c|c|c|}
\hline Reporter/Project & Form & $\begin{array}{l}\text { U.S. or } \\
\text { Foreign }\end{array}$ & Project Type \\
\hline A\&N Electric Cooperative & Long & & \\
\hline Transmission and Distribution Efficiency Improvements & & U.S. & Electric Power G \& T \\
\hline Demand-side Management Load Control Program & & U.S. & Energy End Use \\
\hline Alcan Ingot, Sebree Aluminum Plant & Long & & \\
\hline PFC Emissions Reductions & & U.S. & Halogenates \\
\hline Allegheny Power Service Corporation & Long & & \\
\hline Armstrong Boiler No. 2 Renovation Project & & U.S. & Electric Power G \& T \\
\hline Auxiliary Fuel Switching & & U.S. & Electric Power G \& T \\
\hline Wire Replacement on Transmission Lines & & U.S. & Electric Power G \& T \\
\hline Potomac Edison 138/500 kV System Split & & U.S. & Electric Power G \& T \\
\hline Armstrong Unit 2 - Boiler Controls Replacement & & U.S. & Electric Power G \& T \\
\hline Rivesville Unit No. 6 - Boiler Controls Replacement & & U.S. & Electric Power G \& T \\
\hline R. P. Smith Unit 4 - Boiler Controls Replacement & & U.S. & Electric Power G \& T \\
\hline Hattield Unit 1 - HP/IP Turbine Upgrade & & U.S. & Electric Power G \& T \\
\hline Hatfield Unit 2 - HP/IP Turbine Upgrade & & U.S. & Electric Power G \& T \\
\hline Rivesville Unit 6 - High Pressure Turbine Upgrade & & U.S. & Electric Power G \& T \\
\hline Willow Island - Low Pressure Turbine Upgrade & & U.S. & Electric Power G \& T \\
\hline NOx Compliance with Clean Air Act Ammendments of 1990 & & U.S. & Electric Power G \& T \\
\hline Efficient Distribution Transformers & & U.S. & Electric Power G \& T \\
\hline Application of Capacitors & & U.S. & Electric Power G \& T \\
\hline Economic Conductor Selection & & U.S. & Electric Power G \& T \\
\hline Replace Small Primary Conductors & & U.S. & Electric Power G \& T \\
\hline Conversion to Higher Voltage Distribution & & U.S. & Electric Power G \& T \\
\hline Small Hydroelectric Station Relicensing & & U.S. & Electric Power G \& T \\
\hline Energy Star Transformer Program & & U.S. & Electric Power G \& T \\
\hline Armstrong Boiler No. 1 Renovation Project & & U.S. & Electric Power G \& T \\
\hline Lake Lynn Hydro Electric Station Relicensing & & U.S. & Electric Power G \& T \\
\hline Armstrong Unit 1 - Boiler Controls Replacement & & U.S. & Electric Power G \& T \\
\hline Hatfield Unit 3 - LP Turbine Upgrade & & U.S. & Electric Power G \& T \\
\hline Demand-Side Management Programs & & U.S. & Energy End Use \\
\hline Green Lights Utility Ally Program & & U.S. & Energy End Use \\
\hline Heat Pipe Heat Exchanger & & U.S. & Energy End Use \\
\hline Adjustable Speed Drives for Plastic Injection Molding Machin & & U.S. & Energy End Use \\
\hline Canonsburg Plant Upgrade & & U.S. & Waste Methane \\
\hline Black Oak Property Tree Planting & & U.S. & Carbon Sequestration \\
\hline Fly Ash use as replacement for cement & & U.S. & Other \\
\hline American Electric Power, Inc. & Long & & \\
\hline Heat Rate Improvement Projects (Oper. and Equip. Changes) & & U.S. & Electric Power G \& T \\
\hline Heat Rate Improvement (Due to oper. at higher load factor) & & U.S. & Electric Power G \& T \\
\hline Open-Loop Transmission Groundwire Resistive Loss Reduction & & U.S. & Electric Power G \& T \\
\hline Distribution System Equipment Improvements & & U.S. & Electric Power G \& T \\
\hline Transmission System Reinforcements & & U.S. & Electric Power G \& T \\
\hline Nuclear Plant Improved Utilization & & U.S. & Electric Power G \& T \\
\hline AEP Hydroelectric Facility Improvements & & U.S. & Electric Power G \& T \\
\hline Fuel Switch Coal to Natural Gas (Conesville Unit 1-3) & & U.S. & Electric Power G \& T \\
\hline Residential Demand Side Management Programs & & U.S. & Energy End Use \\
\hline
\end{tabular}


Table C2. 1995 Emissions Reduction Projects Reported

\begin{tabular}{|c|c|c|c|}
\hline Reporter/Project & Form & $\begin{array}{l}\text { U.S. or } \\
\text { Foreign }\end{array}$ & Project Type \\
\hline Commercial/Industrial Demand Side Management Programs & & U.S. & Energy End Use \\
\hline Green Lights & & U.S. & Energy End Use \\
\hline AEP-OPCo-1991P & & U.S. & Carbon Sequestration \\
\hline AEP-OPCo-1991H & & U.S. & Carbon Sequestration \\
\hline AEP-OPCo-1992H & & U.S. & Carbon Sequestration \\
\hline AEP-OPCo-1992P1 & & U.S. & Carbon Sequestration \\
\hline AEP-OPCo-1992P2 & & U.S. & Carbon Sequestration \\
\hline AEP-OPCo-1994P & & U.S. & Carbon Sequestration \\
\hline AEP-OPCo-1994H & & U.S. & Carbon Sequestration \\
\hline AEP-OPCo-1993P1 & & U.S. & Carbon Sequestration \\
\hline AEP-OPCo-1993H1 & & U.S. & Carbon Sequestration \\
\hline AEP-OPCo-1993P2 & & U.S. & Carbon Sequestration \\
\hline AEP-OPCo-1993P3 & & U.S. & Carbon Sequestration \\
\hline AEP-APCo-1993 & & U.S. & Carbon Sequestration \\
\hline AEP-APCo-1994 & & U.S. & Carbon Sequestration \\
\hline AEP-OPCo-1991FM & & U.S. & Carbon Sequestration \\
\hline AEP-OPCo-1992FM & & U.S. & Carbon Sequestration \\
\hline AEP-OPCo-1993FM & & U.S. & Carbon Sequestration \\
\hline AEP-OPCo-1994FM & & U.S. & Carbon Sequestration \\
\hline AEP-IMPCo-1994FM & & U.S. & Carbon Sequestration \\
\hline AEP-IMPCo-1993FM & & U.S. & Carbon Sequestration \\
\hline AEP-APCo-1993FM & & U.S. & Carbon Sequestration \\
\hline AEP-APCo-1994FM & & U.S. & Carbon Sequestration \\
\hline AEP-OPCo-1995P1 & & U.S. & Carbon Sequestration \\
\hline AEP-SOCCo-1995P2 & & U.S. & Carbon Sequestration \\
\hline AEP-SOCCo-1995P3 & & U.S. & Carbon Sequestration \\
\hline AEP-OPCo-1995P4 & & U.S. & Carbon Sequestration \\
\hline AEP-OPCo-1995H1 & & U.S. & Carbon Sequestration \\
\hline AEP-OPCo-1995H2 & & U.S. & Carbon Sequestration \\
\hline AEP-APCO-1993-2 & & U.S. & Carbon Sequestration \\
\hline AEP-AEPSC- 1995 & & U.S. & Carbon Sequestration \\
\hline AEP-OPCO-1995FM & & U.S. & Carbon Sequestration \\
\hline AEP-OPCO-1995FM2 & & U.S. & Carbon Sequestration \\
\hline Rio Bravo Carbon Sequestration Pilot Project & & Foreign & Carbon Sequestration \\
\hline AEP-CSPCO-1995FM & & U.S. & Carbon Sequestration \\
\hline AEP-APCO-1995FM & & U.S. & Carbon Sequestration \\
\hline AEP-APCO-1995FM2 & & U.S. & Carbon Sequestration \\
\hline AEP-APCO-1995FM3 & & U.S. & Carbon Sequestration \\
\hline AEP-I\&M-1995FM & & U.S. & Carbon Sequestration \\
\hline Fly Ash Utilization Program (Cement Replacement) & & U.S. & Other \\
\hline American Forests & Long & & \\
\hline Urban Ecosystem Analysis -- Davis-Monthan, Arizona & & U.S. & Energy End Use \\
\hline Global ReLeaf Forests -- Conecuh, Alabama & & U.S. & Carbon Sequestration \\
\hline Global ReLeaf Forests -- Choccolocco, Alabama & & U.S. & Carbon Sequestration \\
\hline Global ReLeaf Forests -- Cossatot, Arkansas & & U.S. & Carbon Sequestration \\
\hline Global ReLeaf Forests -- Cache River, Arkansas & & U.S. & Carbon Sequestration \\
\hline
\end{tabular}


Table C2. 1995 Emissions Reduction Projects Reported

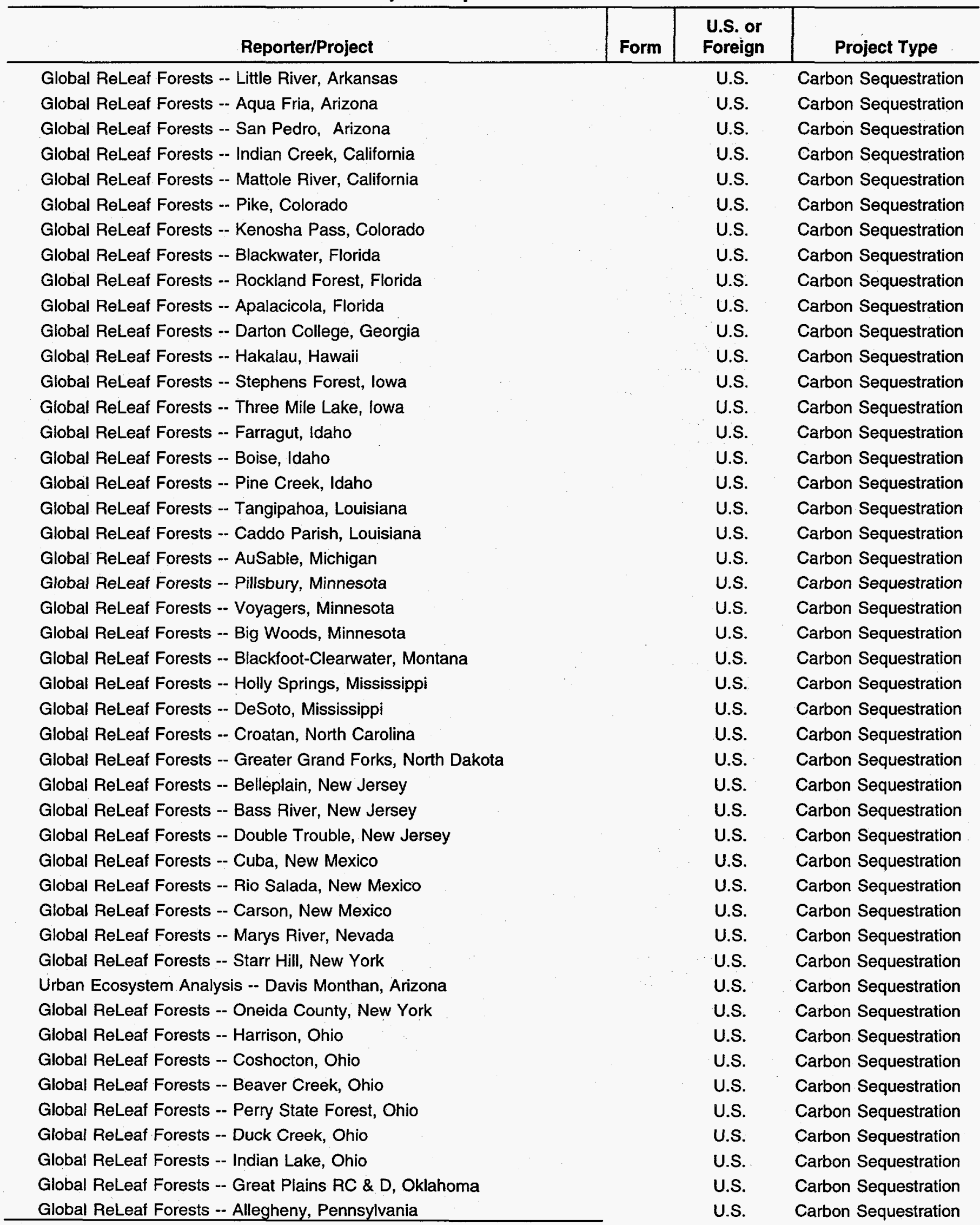


Table C2. 1995 Emissions Reduction Projects Reported

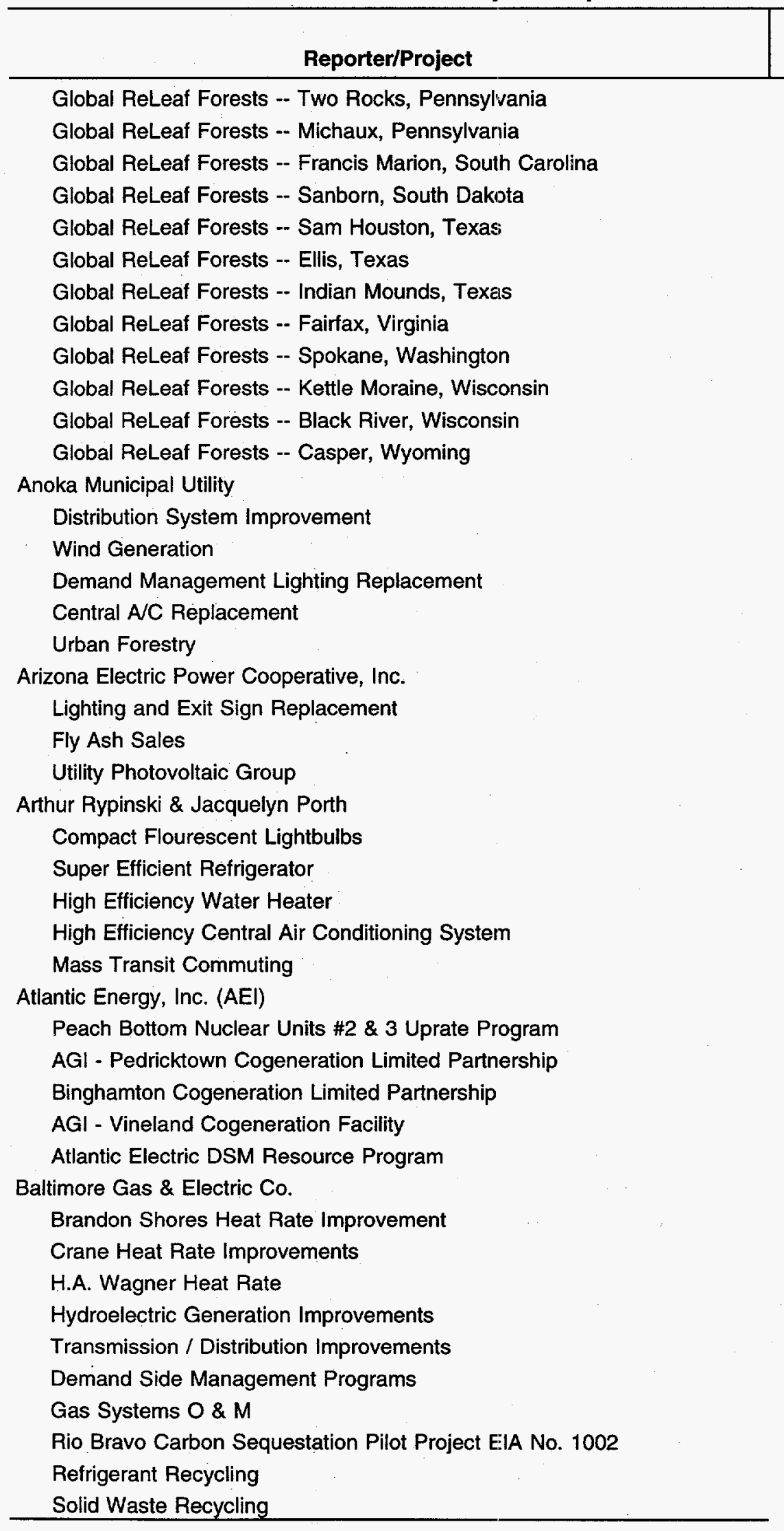

Form

U.S. or Foreign

Project Type

U.S.

U.S.

Carbon Sequestration

U.S.

Carbon Sequestration

U.S.

Carbon Sequestration

U.S.

Carbon Sequestration

U.S.

Carbon Sequestration

U.S.

Carbon Sequestration

U.S.

Carbon Sequestration

U.S.

Carbon Sequestration

U.S.

Carbon Sequestration

U.S.

Carbon Sequestration

U.S.

Carbon Sequestration

Carbon Sequestration

Short

Long

U.S. Electric Power G \& T

U.S. Electric Power $G \& T$

U.S. Energy End Use

U.S. Energy End Use

U.S. Carbon Sequestration

Short

Long
U.S. Energy End Use
U.S. Other
U.S. Other
U.S. Energy End Use
U.S. Energy End Use
U.S. Energy End Use
U.S. Energy End Use
U.S. Transportation

U.S. Electric Power G \& T

U.S. Cogeneration

U.S. Cogeneration

U.S. Cogeneration

U.S. Energy End Use

Long

U.S. Electric Power $G$ \& $T$

U.S. Electric Power $G$ \& $T$

U.S. Electric Power $G$ \& $T$

U.S. Electric Power $G$ \& $T$

U.S. Electric Power $G$ \& $T$

U.S. Energy End Use

U.S. Oil \& Gas Methane

Foreign Carbon Sequestration

U.S. Halogenates

U.S. Other 
Table C2. 1995 Emissions Reduction Projects Reported

\begin{tabular}{|c|c|c|c|}
\hline Reporter/Project & Form & $\begin{array}{l}\text { U.S. or } \\
\text { Foreign }\end{array}$ & Project Type \\
\hline BARC Electric Cooperative & Long & & \\
\hline System Line Conversions and Reconductoring & & U.S. & Electric Power G \& T \\
\hline Demand-Side Management Load Control Programs & & U.S. & Energy End Use \\
\hline Berkeley Electric Cooperative Incorporated & Short & & \\
\hline Load Control Electric Water Heater (New and Replacements) & & U.S. & Energy End Use \\
\hline DSM through Advertising Good Cents Energy Efficient Homes & & U.S. & Energy End Use \\
\hline Blue Earth Light \& Water & Long & & \\
\hline Distribution Upgrade & & U.S. & Electric Power G \& T \\
\hline New Generation & & U.S. & Electric Power G \& T \\
\hline Street Lighting & & U.S. & Energy End Use \\
\hline Compact Fluorescent Retrofits & & U.S. & Energy End Use \\
\hline Hot water insulation blankets & & U.S. & Energy End Use \\
\hline Shower head flow restrictors & & U.S. & Energy End Use \\
\hline Tree planting & & U.S. & Carbon Sequestration \\
\hline Bountiful City Light \& Power & Long & & \\
\hline Hydroelectric plant operations & & U.S. & Electric Power G \& T \\
\hline Capacitor bank installation - increasing system efficiency & & U.S. & Electric Power G \& T \\
\hline Air fuel ratio controller installed in dual fuel engine & & U.S. & Electric Power G \& T \\
\hline District heating & & U.S. & Cogeneration \\
\hline Street lighting replacement & & U.S. & Energy End Use \\
\hline Residential compact fluorescent lighting program & & U.S. & Energy End Use \\
\hline Tree planting & & U.S. & Carbon Sequestration \\
\hline Brooklyn Union & Short & & \\
\hline Rehab of Leaky Distribution Pipe & & U.S. & Oil \& Gas Methane \\
\hline Directed I\&M at surface and subsurface facilit & & U.S. & Oil \& Gas Methane \\
\hline Flaring When Retiring Gas Holders & & U.S. & Oil \& Gas Methane \\
\hline Reduce venting of CNG cylinders & & U.S. & Oil \& Gas Methane \\
\hline Reduct. of Controller Venting at Gate Stations & & U.S. & Oil \& Gas Methane \\
\hline Buckeye Power Incorporated & Short & & \\
\hline Heat Rate Improvement at Cardinal Operating Company & & U.S. & Electric Power G \& T \\
\hline Water Heater Replacement Program & & U.S. & Energy End Use \\
\hline Geothermal Heat Pump Project & & U.S. & Energy End Use \\
\hline Carolina Power \& Light Company & Long & & \\
\hline Nuclear Capacity Improvement & & U.S. & Electric Power G \& T \\
\hline Cedar Falls Utilities & Long & & \\
\hline Streeter Unit 6 Controls Upgrade (PROJECT 1.1) & & U.S. & Electric Power G \& T \\
\hline High-Efficiency Transformers (PROJECT 1.2) & & U.S. & Electric Power G \& $T$ \\
\hline Co-Owned Generation (PROJECT 1.3) & & U.S. & Electric Power G \& T \\
\hline Co-Owned Generation (PROJECT 1.4) & & U.S. & Electric Power G \& T \\
\hline Council Bluffs \#3 ESP Hot-Side Conversion (PROJECT 1.5) & & U.S. & Electric Power G \& T \\
\hline Neal \#4 ESP Hot-Side Conversion (PROJECT 1.6) & & U.S. & Electric Power G \& T \\
\hline Streeter ACC \& VFD (PROJECT 1.7) & & U.S. & Electric Power G \& T \\
\hline City Street Light Conversion (PROJECT 3.1) & & U.S. & Energy End Use \\
\hline Home Energy Survey (PROJECT 3.2) & & U.S. & Energy End Use \\
\hline Good Cents Home Program (New Homes) (PROJECT 3.3) & & U.S. & Energy End Use \\
\hline Good Cents Improved Home (PROJECT 3.4) & & U.S. & Energy End Use \\
\hline
\end{tabular}


Table C2. 1995 Emissions Reduction Projects Reported

\begin{tabular}{|c|c|c|c|}
\hline Reporter/Project & Form & $\begin{array}{l}\text { U.S. or } \\
\text { Foreign }\end{array}$ & Project Type \\
\hline Security Lighting Services (PROJECT 3.5) & & U.S. & Energy End Use \\
\hline Water Heater Jacket Rebate (PROJECT 3.6) & & U.S. & Energy End Use \\
\hline Cedar Falls Trees (PROJECT 8.1) & & U.S. & Carbon Sequestration \\
\hline Centerior Energy Corporation & Long & & \\
\hline Demand Side Management & & U.S. & Energy End Use \\
\hline Various CFC Replacements & & U.S. & Halogenates \\
\hline Use of Ash in Cement Production & & U.S. & Other \\
\hline Central Hudson Gas \& Electric Corp & Long & & \\
\hline Roseton Gas Co-Firing & & U.S. & Electric Power G \& T \\
\hline Danskammer Heat Pipe Air Heater & & U.S. & Electric Power G \& T \\
\hline Roseton Unit 2 Main Step-Up Transformer Replacement & & U.S. & Electric Power G \& T \\
\hline Danskammer Unit 4 Main Step-Up Transformer Replacement & & U.S. & Electric Power G \& T \\
\hline Demand-Side Management & & U.S. & Energy End Use \\
\hline Natural Gas Vehicles & & U.S. & Transportation \\
\hline EPA Natural Gas Star Program & & U.S. & Oil \& Gas Methane \\
\hline Central Illinois Light Company & Long & & \\
\hline E.D. Edwards Unit \#3 Last Stage Bucket Heat Rate Improvement & & U.S. & Electric Power G \& T \\
\hline CILCO Cogen One & & U.S. & Cogeneration \\
\hline Tazewell County Landfill Methane Outreach Program & & U.S. & Waste Methane \\
\hline UtiliTree Carbon Company Forest Management & & Foreign & Carbon Sequestration \\
\hline TreeLine USA Program & & U.S. & Carbon Sequestration \\
\hline Freon TF (CFC-113) Substitution & & U.S. & Halogenates \\
\hline "In Concert With the Environment" Education Program & & U.S. & Other \\
\hline Central Louisiana Electric Co., Inc. & Long & & \\
\hline Cycloid - Domestic & & U.S. & Transportation \\
\hline Choptank Electric Cooperative & Long & & \\
\hline System Line Conversions and Reconductoring & & U.S. & Electric Power G \& T \\
\hline Cinergy Corp. & Long & & \\
\hline Gibson Performance Maximization Program & & U.S. & Electric Power G \& T \\
\hline Cayuga Heat Rate Improvements & & U.S. & Electric Power G \& T \\
\hline Wabash River Heat Rate Improvement & & U.S. & Electric Power G \& T \\
\hline Wabash River Unit 1 Repowering Project & & U.S. & Electric Power G \& T \\
\hline Merger Dispatch Savings & & U.S. & Electric Power G \& T \\
\hline Residential Wrap-Up Program & & U.S. & Energy End Use \\
\hline Residential Energy Efficient Lighting Program & & U.S. & Energy End Use \\
\hline Residential Smart \$aver \& Heat Pump Savings Programs & & U.S. & Energy End Use \\
\hline Residential Seal-Up \& Low-Income Efficiency Program & & U.S. & Energy End Use \\
\hline Commercial Audit/ncentive Program & & U.S. & Energy End Use \\
\hline Commercial Direct Lighting & & U.S. & Energy End Use \\
\hline Industrial Efficiency Improvement \& Energy Awareness Program & & U.S. & Energy End Use \\
\hline Commercial/Industrial Peak Reduction Program & & U.S. & Energy End Use \\
\hline Planergy & & U.S. & Energy End Use \\
\hline Green Lights Program & & U.S. & Energy End Use \\
\hline Commercial//ndustrial Lighting Rebate Program & & U.S. & Energy End Use \\
\hline Thermal Energy (Cool) Storage Program & & U.S. & Energy End Use \\
\hline Commercial/Industrial High Efficiency Motors Plan & & U.S. & Energy End Use \\
\hline
\end{tabular}


Table C2. 1995 Emissions Reduction Projects Reported

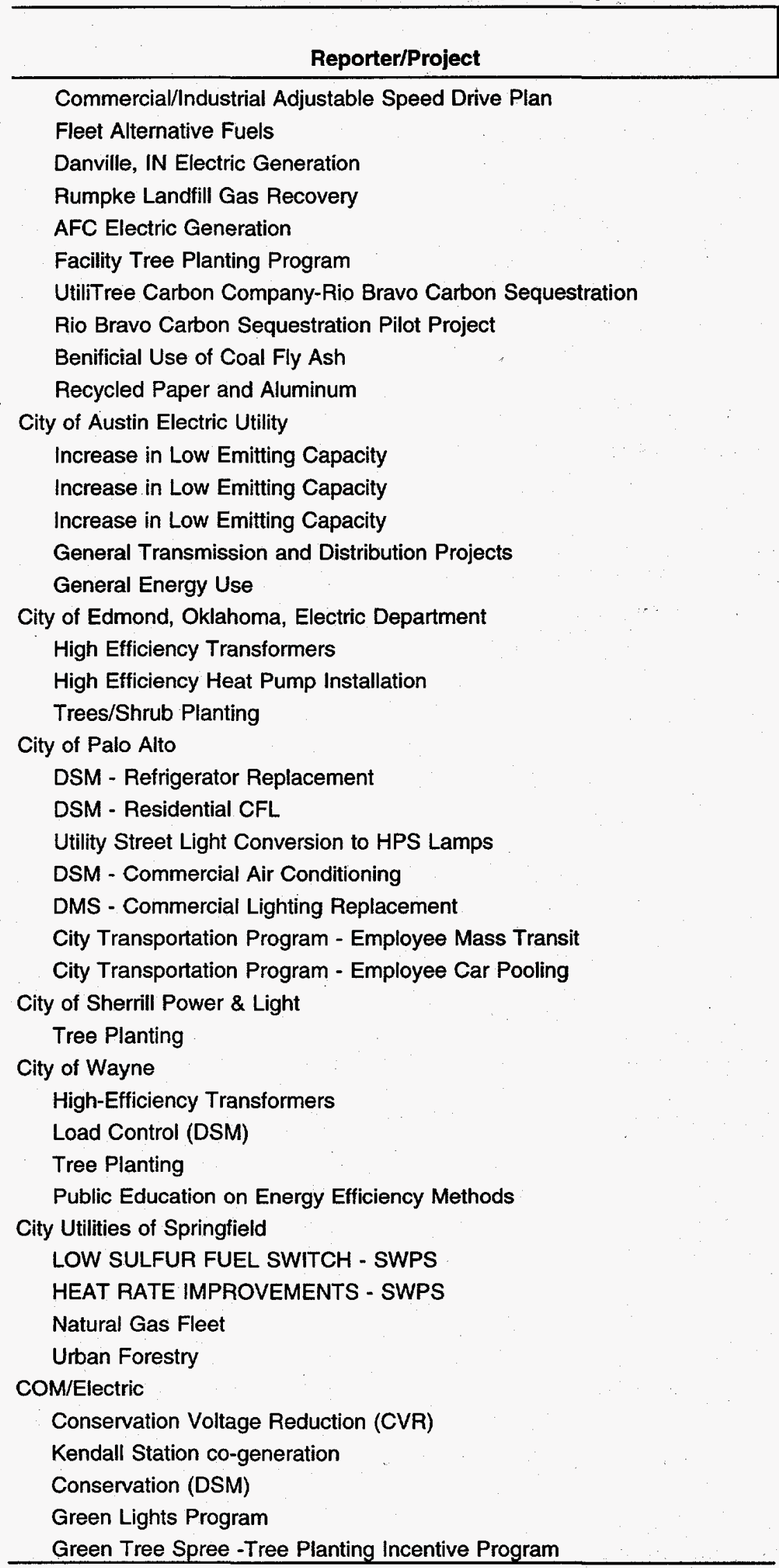

Short

Short

Short
U.S. Electric Power G \& T
U.S. Electric Power G \& T
U.S. Electric Power $G \& T$
U.S. Electric Power $G$ \& $T$
U.S. Energy End Use
U.S. Electric Power G \& $T$
U.S. Energy End Use
U.S. Carbon Sequestration

Short
U.S. Energy End Use
U.S. Energy End Use
U.S. Energy End Use
U.S. Energy End Use
U.S. Energy End Use
U.S. Transportation
U.S. Transportation

U.S. Carbon Sequestration

Short

Long
U.S. Electric Power $\mathrm{G} \& \mathrm{~T}$
U.S. Energy End Use
U.S. Carbon Sequestration
U.S. Other
U.S. Electric Power G \& $T$
U.S. Electric Power $G \& T$
U.S. Transportation
U.S. Carbon Sequestration

Short:

$\begin{array}{ll}\text { U.S. } & \text { Electric Power G \& T } \\ \text { U.S. } & \text { Cogeneration } \\ \text { U.S. } & \text { Energy End Use } \\ \text { U.S. } & \text { Energy End Use } \\ \text { U.S. } & \text { Carbon Sequestration }\end{array}$




\begin{tabular}{|c|}
\hline Reporter/Project \\
\hline $\begin{array}{l}\text { Community Electric Cooperative } \\
\text { System Line Conversion and Reconductoring }\end{array}$ \\
\hline Cooperative Power Association \\
\hline L-O Buckets \\
\hline Ultrasonic \& Helium Leak Detection Improvements \\
\hline Cooling Tower Improvements \\
\hline Energy Intelligent Business \& Farm Grants \\
\hline Efficient Lighting \\
\hline Water Heater Blankets \\
\hline Low-Flow Showerheads \\
\hline Setback Thermostats \\
\hline Excess Water Heating Setting Reductions \\
\hline Water Pipe Insulation \\
\hline Low Interest Financing \\
\hline Capacitor Installation and Control \\
\hline Transformer Sizing and Changeout \\
\hline Low Loss Transformers \\
\hline Loss Reduction Measures \\
\hline Residential and Commercial Audits \\
\hline Other DSM \\
\hline Coal Creek Station Vanpool \\
\hline Tree-planting programs \\
\hline Coal Ash Programs \\
\hline Recycling Projects \& Activities \\
\hline Delaware Electric Cooperative \\
\hline System Line Conversions \& Reconductoring \\
\hline Delmarva Power \\
\hline T\&D Loss Reduction \\
\hline Hay Road Combined Cycle \\
\hline Edge Moor Natural Gas Use \\
\hline DP\&L Facility Energy Saving \\
\hline Demand Side Management \\
\hline CNG Vehicles \\
\hline Edge Moor Landfill Gas Use \\
\hline Urban Tree Planting \\
\hline Ash Reuse \\
\hline Delta Electric Power Association \\
\hline High Efficiency Transformers \\
\hline Reconductoring \\
\hline Load Control Interruptible Rate \\
\hline Conversion - 175 Watt Mercury Vapor to 100 Watt High Pressur \\
\hline Off Peak Pumping and Aeration - Catfish Ponds \\
\hline DTE Energy/ Detroit Edison \\
\hline Increased Nuclear Utilization \\
\hline Greenwood Energy Center Fuel Switching \\
\hline Distribution Improvements \\
\hline
\end{tabular}

Form

Long

U.S. or Foreign

Project Type

U.S. Electric Power G \& T

Long

U.S. Electric Power $G$ \& $T$

U.S. Electric Power $G \& T$

U.S. Electric Power $G$ \& $T$

U.S. Energy End Use

U.S. Energy End Use

U.S. Energy End Use

U.S. Energy End Use

U.S. Energy End Use

U.S. Energy End Use

U.S. Energy End Use

U.S. Energy End Use

U.S. Energy End Use

U.S. Energy End Use

U.S. Energy End Use

U.S. Energy End Use

U.S. Energy End Use

U.S. Energy End Use

U.S. Transportation

U.S. Carbon Sequestration

U.S. Other

U.S. Other

Long

Long

U.S. Electric Power G \& T

U.S. Electric Power G \& T

U.S. Electric Power $G$ \& $T$

U.S. Electric Power $G \& T$

U.S. Energy End Use

U.S. Energy End Use

U.S. Transportation

U.S. Waste Methane

U.S. Carbon Sequestration

U.S. Other

Short

U.S. Electric Power G \& $T$

U.S. Electric Power $G \& T$

U.S. Electric Power $G \& T$

U.S. Energy End Use

U.S. Energy End Use

Long

U.S. Electric Power $G$ \& $T$

U.S. Electric Power $G$ \& $T$

U.S. Electric Power $G \& T$ 
Table C2. 1995 Emissions Reduction Projects Reported

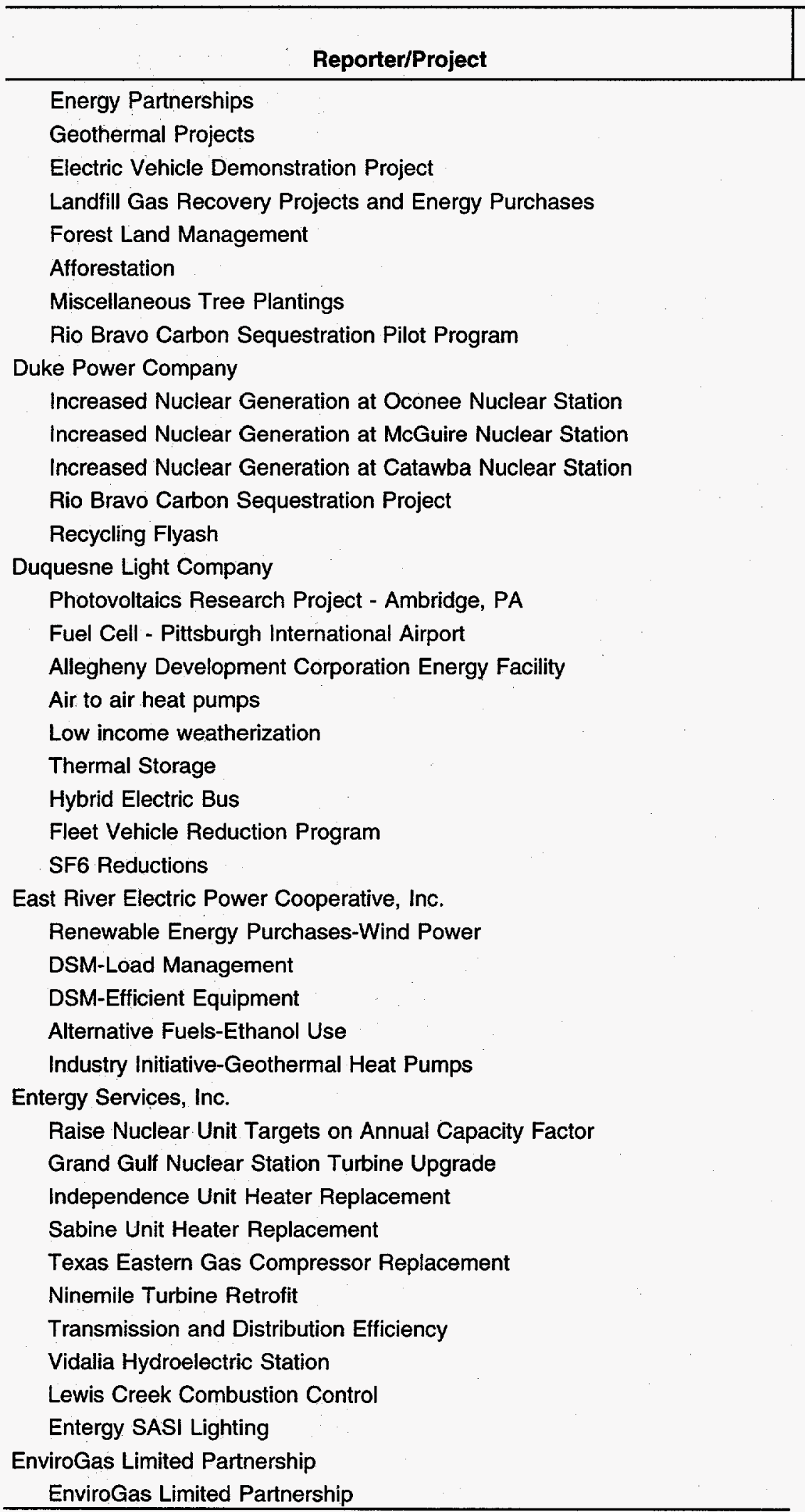

Form

U.S. or Foreign

Project Type

U.S. Energy End Use

U.S. Energy End Use

U.S. Transportation

U.S. Waste Methane

U.S. Carbon Sequestration

U.S. Carbon Sequestration

U.S. Carbon Sequestration

Foreign Carbon Sequestration

Long

U.S. Electric Power G \& T

U.S. Electric Power G \&.T

U.S. Electric Power $\mathrm{G} \& \mathrm{~T}$

Foreign Carbon Sequestration

U.S. Other

Long

Short

U.S. Electric Power G \& $T$

U.S. Electric Power $G \& T$

U.S. Cogeneration

U.S. Energy End Use

U.S. Energy End Use

U.S. Energy End Use

U.S. Transportation

U.S. Transportation

U.S. Halogenates

U.S. Electric Power G \& T

U.S. Energy End Use

U.S. Energy End Use

U.S. Transportation

U.S. Other

Long

U.S. Electric Power $G$ \& $T$

U.S. Electric Power G \& T

U.S. Electric Power $G$ \& $T$

U.S. Electric Power $G$ \& $T$

U.S. Electric Power G \& $T$

U.S. Electric Power G \& T

U.S. Electric Power $G$ \& $T$

U.S. Electric Power $G \& T$

U.S. Electric Power $G$ \& $T$

U.S. Energy End Use

Long

U.S. Waste Methane 


\begin{tabular}{|c|}
\hline Reporter/Project \\
\hline Flint Electric Membership Corporation \\
\hline Transmission and Distribution Upgrades \\
\hline Demand Side Mgt. through Marketing (Heat Pump, Good Cents) \\
\hline Load Control \\
\hline General Motors Corporation \\
\hline 1991 - 1995 General Motors Annual Energy Competition \\
\hline 1993 - 1995 Mich. Demand Side Mgt. and Energy Partner Prog. \\
\hline General Public Utilities Corporation \\
\hline Yards Creek Pumped Storage Upgrade \\
\hline Seneca Pumped Storage Upgrade \\
\hline Sayreville Generating Station Retirements \\
\hline Front Street Generating Station Retirement \\
\hline Williamsburg Generating Station Retirement \\
\hline Transformer Loss Evaluation Program \\
\hline Shunt Capacitor Program \\
\hline T \& D System Improvements \\
\hline TMI Capacity/Availability Improvement Program \\
\hline Oyster Creek Capacity/Availability Improvement Program \\
\hline Biomass Co-firing R \& D Program \\
\hline Photovoltaics Project-User Scale Applications-(USAPV) \\
\hline Homer City Greenhouse Project \\
\hline JCP\&L Fuel Cell-Crawford Hill. \\
\hline Met-Ed/Penelec DSM, Efficiency \& Electrotechnology Program \\
\hline JCP\&L DSM, Efficiency \& Electrotechnology Program \\
\hline JCP \& L Green Lights Program \\
\hline Met-Ed Lighting \& Building Energy Consumption Reduction Prog \\
\hline Building Energy Consumption Reduction Program \\
\hline Genco Lighting \& Building Energy Consumption Reduction Progr \\
\hline Information Services - Green Computers \\
\hline GPU Service Lighting \& Building Energy Efficiency Project \\
\hline Video - Conferencing \\
\hline Electric Vehicles and Employee Trip Reduction Program \\
\hline FR \& S Landfill NUG \\
\hline Lebanon Methane NUG \\
\hline Hamm's Landfill NUG \\
\hline L \& D Landfill NUG \\
\hline Corry \\
\hline Valley Pork \\
\hline Mason Dixon Farms, Inc. \\
\hline Utiltree Carbon Sequestration Project \\
\hline Transmission \& Distribution Facility Maintenance - JCP\&L \\
\hline JCP\&L Applaince Turn-In Service Program \\
\hline Recycling Program \\
\hline Golden Valley Electric Association, Inc \\
\hline Use of Hydropower \\
\hline Energy Sense DSM Program \\
\hline
\end{tabular}

U.S. or

Form

Foreign

Project Type

Short

Long

Long

$\begin{array}{ll}\text { U.S. } & \text { Electric Power G \& T } \\ \text { U.S. } & \text { Energy End Use } \\ \text { U.S. } & \text { Energy End Use }\end{array}$

U.S. Energy End Use

U.S. Energy End Use

U.S. Electric Power G \& T

U.S. Electric Power $G$ \& $T$

U.S. Electric Power $G \& T$

U.S. Electric Power $G \& T$

U.S. Electric Power $\mathrm{G} \& \mathrm{~T}$

U.S. Electric Power $G \& T$

U.S. Electric Power $G \& T$

U.S. Electric Power $G \& T$

U.S. Electric Power $G$ \& $T$

U.S. Electric Power $G \& T$

U.S. Electric Power $G \& T$

U.S. Electric Power G \& T

U.S. Cogeneration

U.S. Cogeneration

U.S. Energy End Use

U.S. Energy End Use

U.S. Energy End Use

U.S. Energy End Use

U.S. Energy End Use

U.S. Energy End Use

U.S. Energy End Use

U.S. Energy End Use

U.S. Transportation

U.S. Transportation

U.S. Waste Methane

U.S. Waste Methane

U.S. Waste Methane

U.S. Waste Methane

U.S. Waste Methane

U.S. Agriculture

U.S. Agriculture

Foreign Carbon Sequestration

U.S. Halogenates

U.S. Halogenates

U.S. Other

Short

U.S. Electric Power G \& T

U.S. Energy End Use 
Table C2. 1995 Emissions Reduction Projects Reported

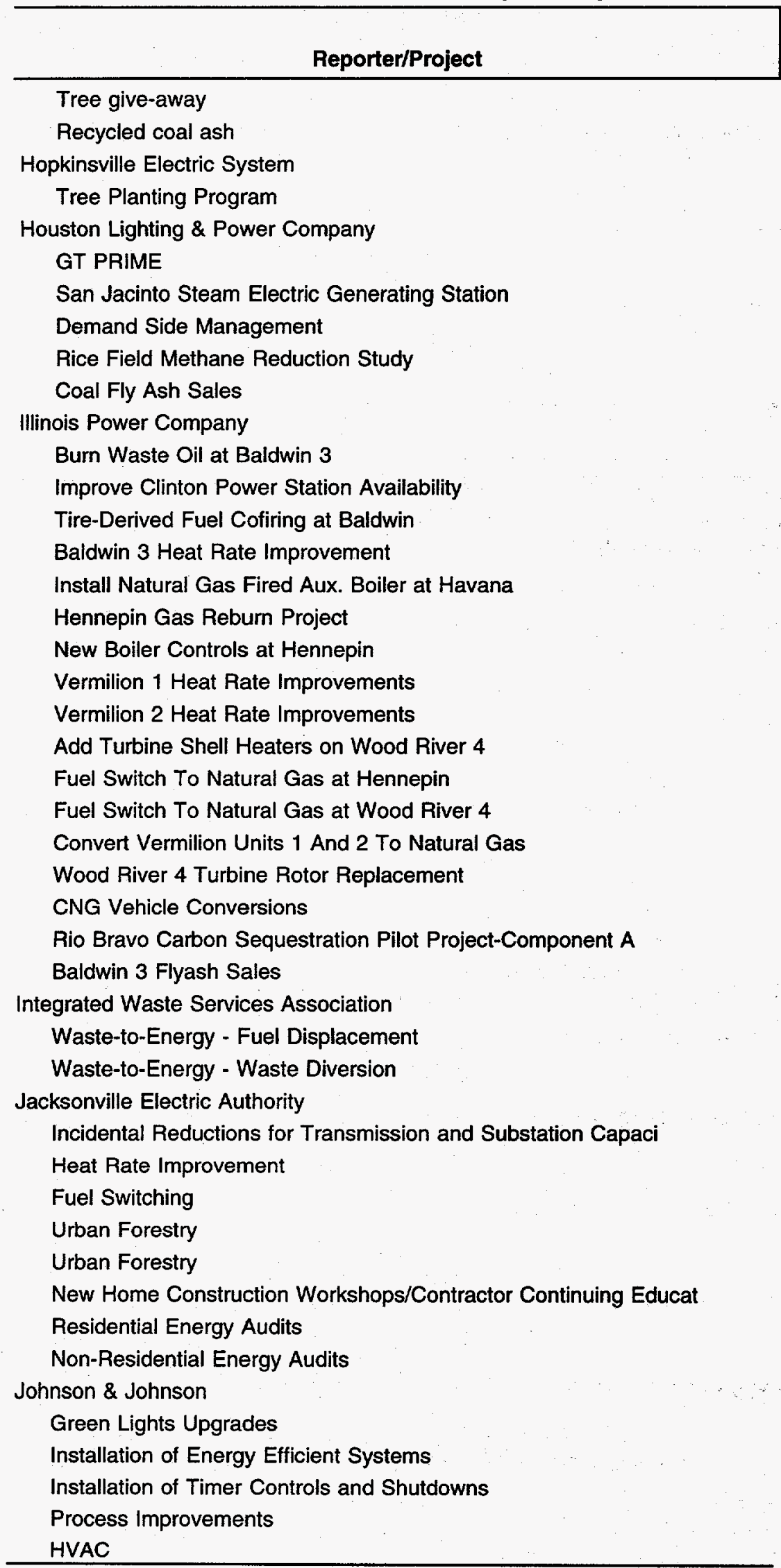

\begin{tabular}{|c|c|}
\hline & $\begin{array}{r}\text { U.S. or } \\
\text { Foreign }\end{array}$ \\
\hline
\end{tabular}

U.S. Carbon Sequestration

U.S. Other

Short

Long

U.S. Carbon Sequestration

U.S. Electric Power G \& T

U.S. Cogeneration

U.S. Energy End Use

U.S. Agriculture

U.S. Other

Long

U.S. Electric Power G \& $T$

U.S. Electric Power $G \& T$

U.S. Electric Power $G \& T$

U.S. Electric Power $G \& T$

U.S. Electric Power $G \& T$

U.S. Electric Power $G \& T$

U.S. Electric Power $G \& T$

U.S. Electric Power $G \& T$

U.S. Electric Power $G \& T$

U.S. Electric Power $G \& T$

U.S. Electric Power G \& T

U.S. Electric Power G \& $T$

U.S. Electric Power G \& $T$

U.S. Electric Power $G \& T$

U.S. Transportation

Foreign Carbon Sequestration

U.S. Other

Long

U.S. Electric Power G \& T

U.S. Waste Methane

Short

U.S. Electric Power $G$ \& $T$

U.S. Electric Power $G$ \& $T$

U.S. Electric Power $G \& T$

U.S. Carbon Sequestration

U.S. Carbon Sequestration

U.S. Other

U.S. Other

U.S. Other

Long
U.S. Energy End Use
U.S. . Energy End Use
U.S. Energy End Use
U.S. Energy End Use
U.S. Energy End Use 
Table C2. 1995 Emissions Reduction Projects Reported

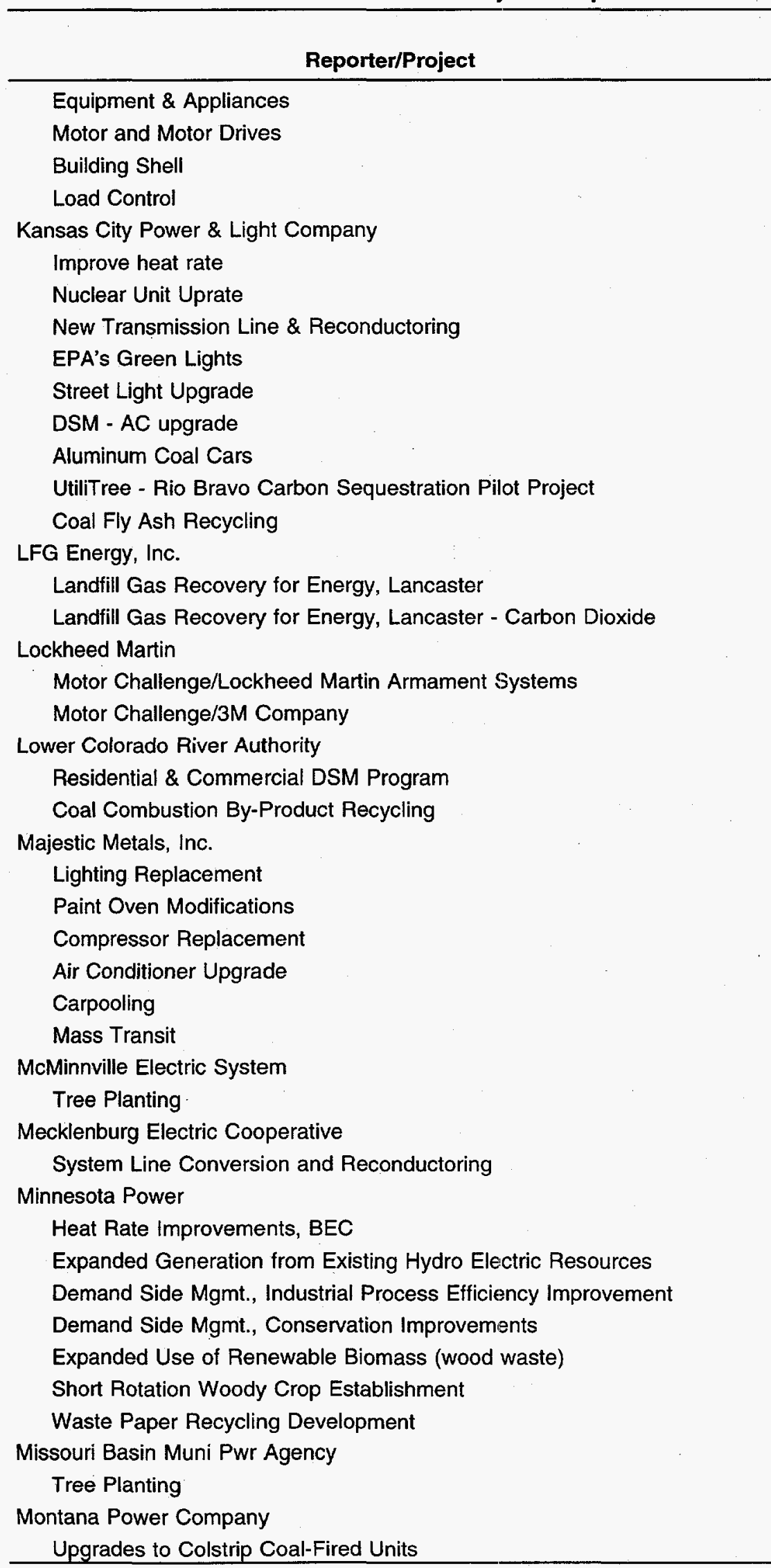

Form

U.S. or Foreign

U.S.

U.S.

U.S.

U.S.

Long

U.S. Electric Power $G$ \& $T$

U.S. Electric Power $G$ \& $T$

U.S. Electric Power G \& T

U.S. Energy End Use

U.S. Energy End Use

U.S. Energy End Use

U.S. Transportation

Foreign - Carbon Sequestration

U.S. Other

Short

Long
U.S.
Waste Methane
U.S. Waste Methane

$\begin{array}{ll}\text { U.S. } & \text { Energy End Use } \\ \text { U.S. } & \text { Energy End Use }\end{array}$

Long

Short

Short
U.S. Energy End Use
U.S. Other
U.S. Energy End Use
U.S. Energy End Use
U.S. Energy End Use
U.S. Energy End Use
U.S. Transportation
U.S. Transportation

U.S. Carbon Sequestration Long

Long

U.S. Electric Power G \& T

U.S. Electric Power G \& $T$

U.S. Electric Power $G$ \& $T$

U.S. Energy End Use

U.S. Energy End Use

U.S. Energy End Use

U.S. Carbon Sequestration

U.S. Other

Short

U.S. Carbon Sequestration Long 
Table C2. 1995 Emissions Reduction Projects Reported

\begin{tabular}{|c|}
\hline Reporter/Project \\
\hline Hydro-Electric Plant Upgrades \\
\hline Demand Side Management Programs \\
\hline Natural Gas Vehicles - Fleet Conversion \\
\hline Gas Plant Catalytic Converters \\
\hline Sale of Fly Ash \\
\hline Moorhead Public Service \\
\hline Insulation Improvement \\
\hline Lighting Retrofit Program \\
\hline Custom rebate for energy efficiency improvements \\
\hline Urban Forestry (sequestration only) \\
\hline Mora Municipal Utilities \\
\hline Demand Side Management (Load Management) \\
\hline Demand Side Management (Lighting Replacement) \\
\hline Tree Planting \\
\hline Municipal Electric Authority of Georgia \\
\hline Nuclear Generation Utilization \\
\hline N.W. Electric Power Cooperative, Inc. \\
\hline Market and Sell Geothermal Heat Pumps \\
\hline Nashville Electric Service \\
\hline Distribution Voltage Upgrade \\
\hline High-efficiency transformers \\
\hline Urban Forestry (sequestration only) \\
\hline Nebraska Public Power District \\
\hline Plant Efficiency Improvements \\
\hline Transformer Changeout \\
\hline Distribution Improvements \\
\hline Hydro Efficiency Improvements \\
\hline Street Light Conversions \\
\hline New England Electric System (NEES) Companies \\
\hline Brayton Point Station Unit No. 4 Gas Conversion \\
\hline Power Purchases from Natural Gas Generation \\
\hline Manchester Street Repowering \\
\hline Demand-Side Management Programs \\
\hline Green Lights Program \\
\hline Johnston Landfill Gas to Electricity Project \\
\hline Turnkey Landfill Gas to Electricity Project \\
\hline Reduced Impact Logging Project \\
\hline Rio Bravo Carbon Sequestration Pilot Project \\
\hline Appliance Removal Program \\
\hline Coal Ash Recycling as Cement Replacement \\
\hline Niagara Mohawk Power Corporation \\
\hline Nuclear Generation Performance Improvements \\
\hline Amorphous Metal Core Transformers \\
\hline Installation and Operation of Wind Turbines \\
\hline Installation and Operation of Photovoltaic Energy Systems \\
\hline Nuclear Generation Capacity Improvements \\
\hline
\end{tabular}

Form

U.S. or
Foreign

Project Type

U.S. Electric Power G \& T

U.S. Energy End Use

U.S. Transportation

U.S. Oil \& Gas Methane

U.S. Other

Short

Short
U.S. Energy End Use
U.S. Energy End Use
U.S. Energy End Use
U.S. Carbon Sequestration

$\begin{array}{lll} & \begin{array}{l}\text { U.S. } \\ \text { U.S. }\end{array} & \begin{array}{l}\text { Energy End Use } \\ \text { Energy End Use } \\ \text { L.S. }\end{array} \\ \text { Larbon Sequestration } \\ \text { Short } & \text { U.S. } & \text { Electric Power G \& T } \\ \text { Short } & \text { U.S. } & \text { Energy End Use } \\ & \text { U.S. } & \text { Electric Power G \& T } \\ & \text { U.S. } & \text { Electric Power G \& T } \\ & \text { U.S. } & \text { Carbon Sequestration }\end{array}$

Short

U.S. Electric Power G \& T

U.S. Electric Power $G$ \& $T$

U.S. Electric Power $G$ \& $T$

U.S. Electric Power $G$ \& $T$

U.S. Energy End Use

Long

U.S. Electric Power $\mathrm{G} \& \mathrm{~T}$

U.S. Electric Power $G \& T$

U.S. Electric Power $G$ \& $T$

U.S. Energy End Use

U.S. Energy End Use

U.S. Waste Methane

U.S. Waste Methane

Foreign Carbon Sequestration

Foreign Carbon Sequestration

U.S. Halogenates

U.S. Other

Long

U.S. Electric Power G \& T

U.S. Electric Power $G \& T$

U.S. Electric Power $G \& T$

U.S. Electric Power $G \& T$

U.S. Electric Power $G \& T$ 


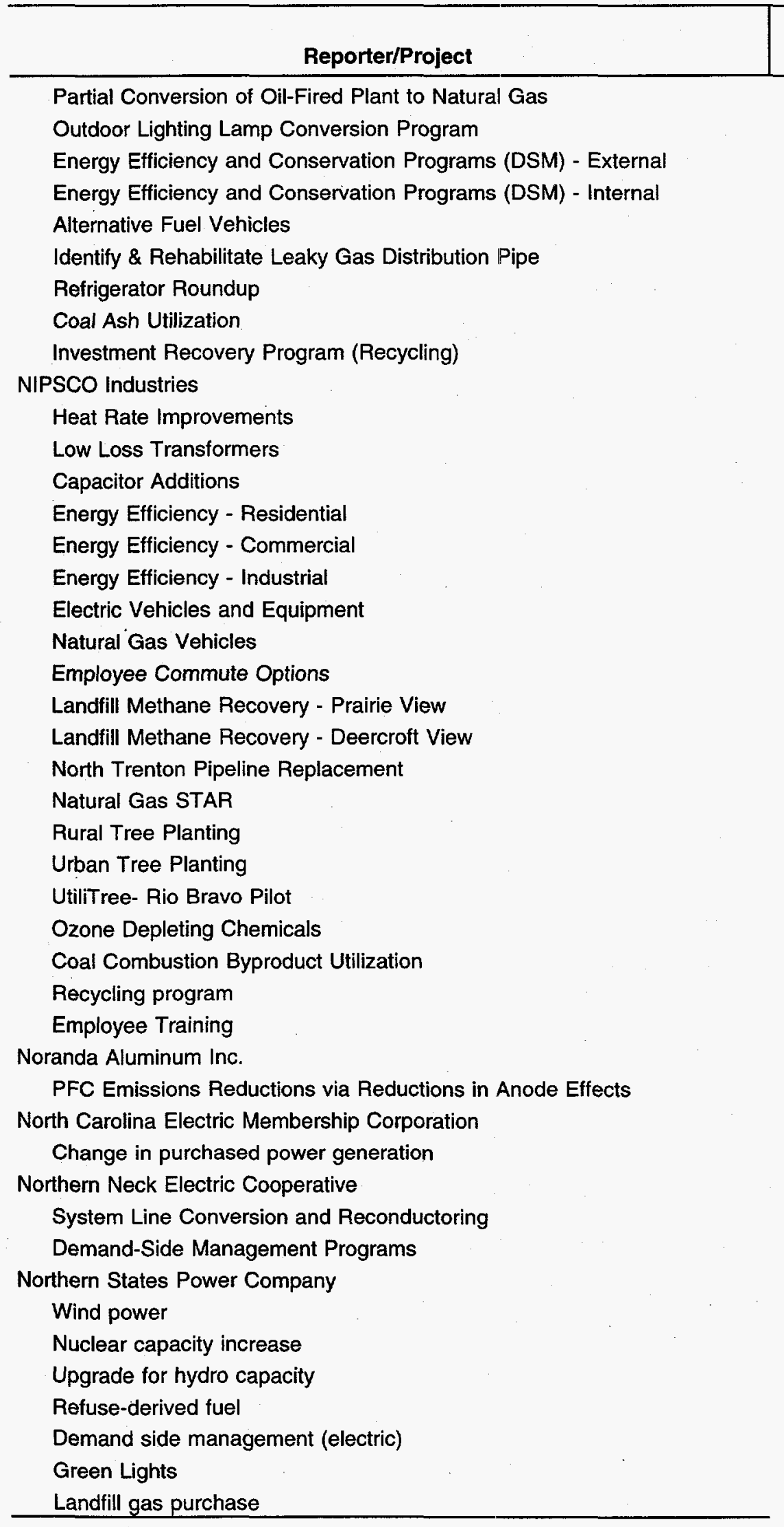

Form

U.S. or
Foreign

Fis.

Project Type

U.S. Electric Power G \& T

U.S. Energy End Use

U.S. Energy End Use

U.S. Energy End Use

U.S. Transportation

U.S. Oil \& Gas Methane

U.S. Halogenates

U.S. Other

U.S. Other

Long

U.S. Electric Power G \& T

U.S. Electric Power G \& T

U.S. Electric Power $G$ \& $T$

U.S. Energy End Use

U.S. Energy End Use

U.S. Energy End Use

U.S. Transportation

U.S. Transportation

U.S. Transportation

U.S. Waste Methane

U.S. Waste Methane

U.S. Oil \& Gas Methane

U.S. Oil \& Gas Methane

U.S. Carbon Sequestration

U.S. Carbon Sequestration

Foreign Carbon Sequestration

U.S. Halogenates

U.S. Other

U.S. Other

U.S. Other

Long

U.S. Halogenates

Short

Long

U.S. Electric Power G \& T

U.S. Electric Power G \& T

U.S. Energy End Use

Long

U.S. Electric Power G \& T

U.S. Electric Power $G \& T$

U.S. Electric Power $G \& T$

U.S. Electric Power G \& T

U.S. Energy End Use

U.S. Energy End Use

U.S. Waste Methane 


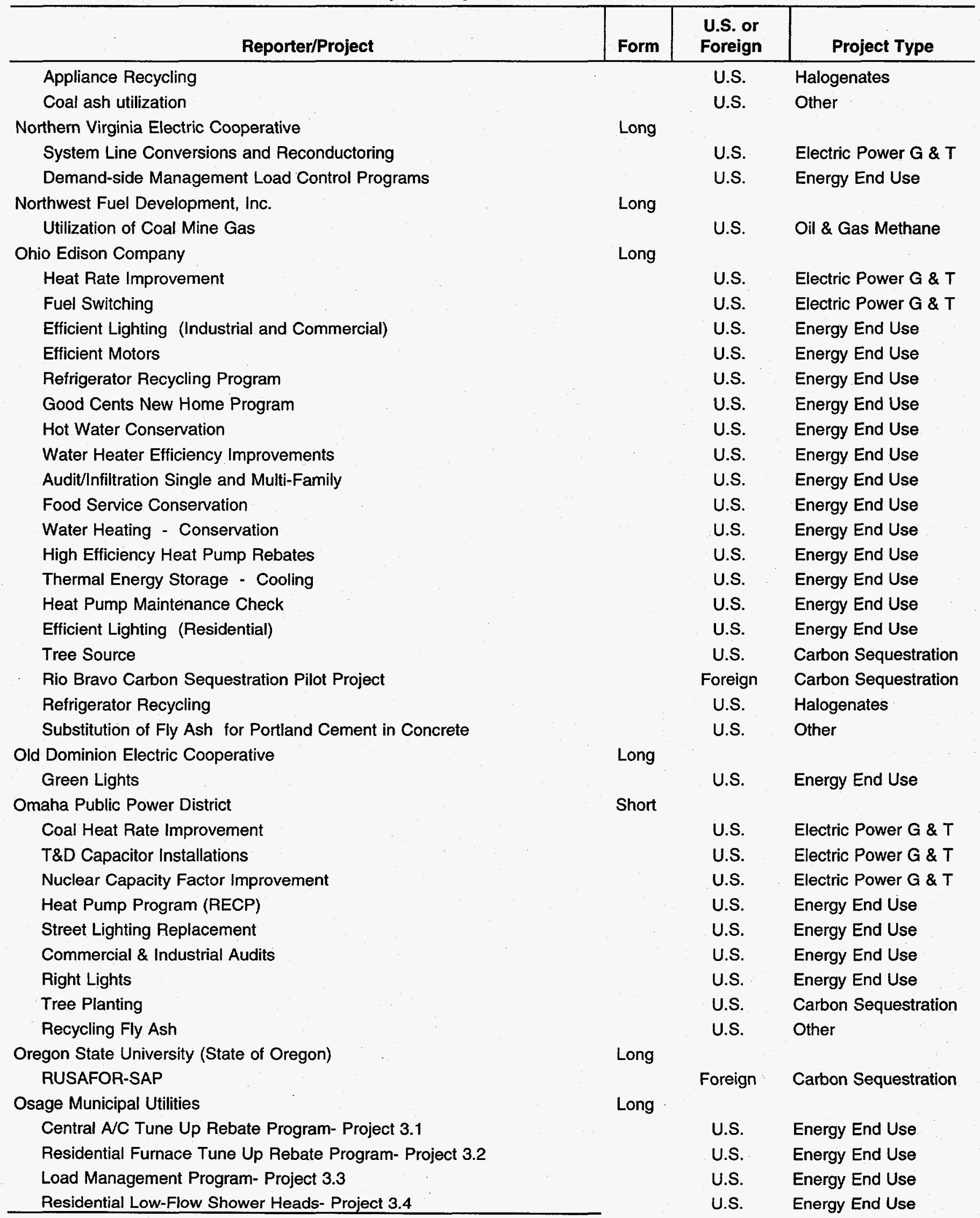


Table C2. 1995 Emissions Reduction Projects Reported

\begin{tabular}{|c|c|c|c|}
\hline Reporter/Project & Form & $\begin{array}{l}\text { U.S. or } \\
\text { Foreign }\end{array}$ & Project Type \\
\hline Residential Water Heater Jackets- Project 3.5 & & U.S. & Energy End Use \\
\hline Faucet Aerator Project- Project 3.7 & & U.S. & Energy End Use \\
\hline Compact Fluorescent Lighting Rebate Prograrn-Project 3.8 & & U.S. & Energy End Use \\
\hline Overhead Door Replacement at Municipal Complex- Project 1.3 & & U.S. & Energy End Use \\
\hline Tree-Planting Program- Project 8.1 & & U.S. & Carbon Sequestration \\
\hline Pacific Gas and Electric Company & Short & & \\
\hline New 1995 Electric Energy Efficiency & & U.S. & Energy End Use \\
\hline Prior Electric Energy Efficiency in 1995 & & U.S. & Energy End Use \\
\hline Prior CNG Vehicles in 95 (PG\&E and customers) & & U.S. & Transportation \\
\hline Pacificorp & Long & & \\
\hline Salt Lake City Urban Forestry Project & & U.S. & Energy End Use \\
\hline Super Good Cents & & U.S. & Energy End Use \\
\hline Manufactured Housing Acquisition Program (MAP) & & U.S. & Energy End Use \\
\hline Low Income Weatherization and Conservation Programs & & U.S. & Energy End Use \\
\hline Residential Weatherization Programs & & U.S. & Energy End Use \\
\hline Home Comfort & & U.S. & Energy End Use \\
\hline Water Heater / Solar & & U.S. & Energy End Use \\
\hline Energy FinAnswer Retrofit & & U.S. & Energy End Use \\
\hline Industrial Energy FinAnswer & & U.S. & Energy End Use \\
\hline Major Accounts Program & & U.S. & Energy End Use \\
\hline Irrigation FinAnswer Program & & U.S. & Energy End Use \\
\hline Residential Competitive Bid - ECONS & & U.S. & Energy End Use \\
\hline Small Commercial Retrofit & & U.S. & Energy End Use \\
\hline Commercial Competitive Bid - EUAVOnsite & & U.S. & Energy End Use \\
\hline Competitive Bid - CESMay & & U.S. & Energy End Use \\
\hline Salt Lake City Urban Forestry Project & & U.S. & Carbon Sequestration \\
\hline Reforestation in Eastern Washington & & U.S. & Carbon Sequestration \\
\hline Reforestation of Private Lands in Oregon - Site Class III & & U.S. & Carbon Sequestration \\
\hline Reforestation of Private Lands in Oregon - Site Class II & & U.S. & Carbon Sequestration \\
\hline Rio Bravo Carbon Sequestration Pilot Project & & Foreign & Carbon Sequestration \\
\hline Coal Ash Recycling & & U.S. & Other \\
\hline Ethanol Production Carbon Offset Project & & U.S. & Other \\
\hline
\end{tabular}

Peabody Holding Company, Inc.

Long

Coal Bed Methane Utilization

U.S. Oil \& Gas Methane 


\begin{tabular}{|c|c|c|c|}
\hline Reporter/Project & Form & $\begin{array}{l}\text { U.S. or } \\
\text { Foreign }\end{array}$ & Project Type \\
\hline Pennsylvania Power \& Light Co. (PP\&L) & Long & & \\
\hline Susquehanna Steam Electric Station Re-Rate & & U.S. & Electric Power G \& T \\
\hline Transformer Savings & & U.S. & Electric Power G \& T \\
\hline Fossil Plant Efficiency & & U.S. & Electric Power G \& T \\
\hline Demand Side Management Project & & U.S. & Energy End Use \\
\hline Trees for the Future & & U.S. & Carbon Sequestration \\
\hline Ash Use in Cement Making & & U.S. & Other \\
\hline Portland General Electric Co. & Long & & \\
\hline T\&D: Power Factor Correction Capacitors & & U.S. & Electric Power G \& T \\
\hline Oak Grove Turbine Runner Replacements - 1991 - Units $1 \& 2$ & & U.S. & Electric Power G \& T \\
\hline Sullivan turbine rebuilds & & U.S. & Electric Power G \& T \\
\hline Bull Run Turbin Runner Replacements & & U.S. & Electric Power G \& T \\
\hline Faraday Units 4\&5 1994 & & U.S. & Electric Power G \& T \\
\hline Beaver Efficiency Improvements & & U.S. & Electric Power G \& T \\
\hline Boardman Efficiency Improvements & & U.S. & Electric Power G \& T \\
\hline Transformer Efficiency Improvements & & U.S. & Electric Power G \& T \\
\hline Photovoltaic Streetlight Controls & & U.S. & Electric Power G \& T \\
\hline 1995 Colstip Units $3 \& 4$ Ruggedizing & & U.S. & Electric Power G \& T \\
\hline Demand-Side Management Projects & & U.S. & Energy End Use \\
\hline Green Lights Programs & & U.S. & Energy End Use \\
\hline Natural Gas Fleet Vehicles & & U.S. & Transportation \\
\hline Potomac Electric Power Company & Long & & \\
\hline GLP -- Lighting Replacement & & U.S. & Energy End Use \\
\hline Energy Mngt/Conservation Programs & & U.S. & Energy End Use \\
\hline Investment Recovery & & U.S. & Other \\
\hline Coal Combustion By-Product Utilization & & U.S. & Other \\
\hline Prince George Electric Cooperative & Long & & \\
\hline Transmission and Dist. Efficiency Improvements & & U.S. & Electric Power G \& T \\
\hline Public Utility District No. 1 of Snohomish County & Long & & \\
\hline Transmission Networking and Reconductoring & & U.S. & Electric Power G \& T \\
\hline Conservation Voltage Reduction & & U.S. & Electric Power G \& T \\
\hline Demand Side Management & & U.S. & Energy End Use \\
\hline Commute Reduction Program & & U.S. & Transportation \\
\hline Bicycles for Meter Readers & & U.S. & Transportation \\
\hline Battery and Solar Powered Boat Races & & U.S. & Transportation \\
\hline Electric Car Race & & U.S. & Transportation \\
\hline We-cycle Office Wastepaper (WOW) Program & & U.S. & Other \\
\hline Puget Sound Power \& Light Company & Long & & \\
\hline Demand Side Management & & U.S. & Energy End Use \\
\hline Quad/Graphics, Inc. & Long & & \\
\hline Energy Efficient Installations & & U.S. & Energy End Use \\
\hline Duplainville return load project & & U.S. & Transportation \\
\hline New Mass Transit routes & & U.S. & Transportation \\
\hline 12 hour shift & & U.S. & Transportation \\
\hline Waste Paper Reduction Program & & U.S. & Other \\
\hline West Allis Plant Brownfield Site & & U.S. & Other \\
\hline
\end{tabular}


Table C2. 1995 Emissions Reduction Projects Reported

\begin{tabular}{|c|c|c|c|}
\hline Reporter/Project & Form & $\begin{array}{l}\text { U.S. or } \\
\text { Foreign }\end{array}$ & Project Type \\
\hline Rappahannock Electric Cooperative & Long & & \\
\hline System Line Conversions and Reconductoring & & U.S. & Electric Power G \& T \\
\hline Tree Planting & & U.S. & Carbon Sequestration \\
\hline Rochester Institute of Technology & Long & & \\
\hline Campus LED Exit Signs & & U.S. & Energy End Use \\
\hline Occupancy Sensors & & U.S. & Energy End Use \\
\hline T-8 Lamps James Booth - 7A & & U.S. & Energy End Use \\
\hline T-8 Lamps, College of Science & & U.S. & Energy End Use \\
\hline T-8 Lamps - Liberal Arts & & U.S. & Energy End Use \\
\hline T-8 Lamps, Chester Carison & & U.S. & Energy End Use \\
\hline Compact Fluorescent Lamps & & U.S. & Energy End Use \\
\hline T-8 Lamps - Frank Gannett & & U.S. & Energy End Use \\
\hline T-8 Lamps - George Eastman & & U.S. & Energy End Use \\
\hline Salt River Project & Short & & \\
\hline Heat Rate Improvement & & U.S. & Electric Power G \& T \\
\hline Lighting Replacement & & U.S. & Energy End Use \\
\hline Electric Vehicles Demonstration and Business Use & & U.S. & Transportation \\
\hline Carpooling & & U.S. & Transportation \\
\hline Replaced R-11 with R-123 & & U.S. & Halogenates \\
\hline Fly Ash Sales & & U.S. & Other \\
\hline Cooperative Photovoltaic and Fuel Cell & & U.S. & Other \\
\hline Halophyte Farming & & U.S. & Other \\
\hline Santee Cooper & Long & & \\
\hline Cross Unit 2 Upgrade & & U.S. & Electric Power G \& T \\
\hline Winyah Unit 1 Turbine Upgrade & & U.S. & Electric Power G \& T \\
\hline Summer Nuclear Upgrade & & U.S. & Electric Power G \& T \\
\hline Demand Side Management Programs & & U.S. & Energy End Use \\
\hline Forestation/Reforestation & & U.S. & Carbon Sequestration \\
\hline Fly Ash Used in Cement Manufacture & & U.S. & Other \\
\hline Seattle City Light & Long & & \\
\hline Gorge Dam turbine runner replacement & & U.S. & Electric Power G \& T \\
\hline Diablo Dam turbine runner replacement & & U.S. & Electric Power G \& $T$ \\
\hline Ross Dam turbine runner replacement & & U.S. & Electric Power G \& T \\
\hline Cedar Falls turbine runner replacement & & U.S. & Electric Power G \& T \\
\hline $4 \mathrm{kV}$ to $26 \mathrm{kV}$ Distribution System Conversion & & U.S. & Electric Power G \& T \\
\hline South Fork Tolt River hydroelectric project & & U.S. & Electric Power G \& T \\
\hline Home Water Savers Program & & U.S. & Energy End Use \\
\hline Multifamily Common Area Lighting Program (MF-CAL) & & U.S. & Energy End Use \\
\hline Warm Home Program (WMHM) & & U.S. & Energy End Use \\
\hline Long-Term Super Good Cents Program (LTSGC) & & U.S. & Energy End Use \\
\hline Energy Efficient Water Heater Rebate Program (EEWHRP) & & U.S. & Energy End Use \\
\hline Energy Smart Design & & U.S. & Energy End Use \\
\hline Energy \$avings Plan (E\$P) & & U.S. & Energy End Use \\
\hline Multifamily Conservation Program: Standard-Income & & U.S. & Energy End Use \\
\hline Multifamily Conservation Program: Low-Income & & U.S. & Energy End Use \\
\hline
\end{tabular}




\begin{tabular}{|c|c|c|c|}
\hline Reporter/Project & Form & $\begin{array}{l}\text { U.S. or } \\
\text { Foreign }\end{array}$ & Project Type \\
\hline Low-Income Electric Program & & U.S. & Energy End Use \\
\hline Urban Tree Replacement Program & & U.S. & Carbon Sequestration \\
\hline Seminole Electric Coop., Inc. & Short & & \\
\hline Heat Rate Improvement & & U.S. & Electric Power G \& T \\
\hline Transmission Conductor Optimization & & U.S. & Electric Power G \& T \\
\hline Lighting Replacement & & U.S. & Energy End Use \\
\hline Fly Ash and Bottom Ash Reuse & & U.S. & Other \\
\hline Seneca Energy, Inc. & Short & & \\
\hline Seneca Energy, Seneca Meadows Landfill, Seneca Falls, NY & & U.S. & Waste Methane \\
\hline Seneca Energy, Seneca Meadows Landfill, Seneca Falls - CO2 & & U.S. & Waste Methane \\
\hline Seneca Meadows, Inc. & Short & & \\
\hline Seneca Meadows Landfill, Seneca Falls, New York & & U.S. & Waste Methane \\
\hline Seneca Meadows Landfill, Seneca Falls, New York - CO2 & & U.S. & Waste Methane \\
\hline Shenandoah Valley Electric Cooperative & Long & & \\
\hline System Line Conversions and Reconductoring & & U.S. & Electric Power G \& T \\
\hline Energy Efficient Transformers & & U.S. & Electric Power G \& T \\
\hline Demand-Side Management Load Control Programs & & U.S. & Energy End Use \\
\hline Visual Screening-Tree Planting & & U.S. & Carbon Sequestration \\
\hline Shrewsbury Electric Light Plan & Short & & \\
\hline High-Efficiency Transformers & & U.S. & Electric Power G \& T \\
\hline Lighting Replacement & & U.S. & Energy End Use \\
\hline Sierra Pacific Power Company & Long & & \\
\hline Geothermal Contracts & & U.S. & Electric Power G \& T \\
\hline Fuel Switching (Residual Oil to NG) - Tracy Plant & & U.S. & Electric Power G \& T \\
\hline Heat Rate Improvements & & U.S. & Electric Power G \& T \\
\hline Demand Side Management Measures & & U.S. & Energy End Use \\
\hline CNG Fleet Vehicles & & U.S. & Transportation \\
\hline Rio Bravo Carbon Sequestration Pilot Project & & Foreign & Carbon Sequestration \\
\hline Valmy 1 Fly Ash Reuse & & U.S. & Other \\
\hline SOUTHERN CALIFORNIA EDISON CO. & Long & & \\
\hline Renewable Energy Purchases - Wind & & U.S. & Electric Power G \& T \\
\hline Renewable Energy Purchases - Geothermal & & U.S. & Electric Power G \& T \\
\hline Renewable Energy Purchases - Biomass & & U.S. & Electric Power G \& T \\
\hline Demand Side Management & & U.S. & Energy End Use \\
\hline ENVEST SCE & & U.S. & Energy End Use \\
\hline Southside Electric Cooperative & Long & & \\
\hline System Line Conversion and Reconductoring & & U.S. & Electric Power G \& T \\
\hline Steuben Rural Electric Co-op & Short & & \\
\hline Other Transmission \& Distribution Improvements & & U.S. & Electric Power G \& T \\
\hline Water Heater Control Program & & U.S. & Energy End Use \\
\hline Sunbelt Land and Mineral Co., Inc & Long & & \\
\hline Smith Place Tract & & U.S. & Carbon Sequestration \\
\hline Tacoma Public Utilities & Short & & \\
\hline Generator Improvement (Cushman/Nisqually) & & U.S. & Electric Power G \& T \\
\hline Generator improvement (Wynochee) & & U.S. & Electric Power G \& T \\
\hline Fuel Switching (Steam Plant No.2 - wood waste and RDF) & & U.S. & Electric Power G \& T \\
\hline
\end{tabular}




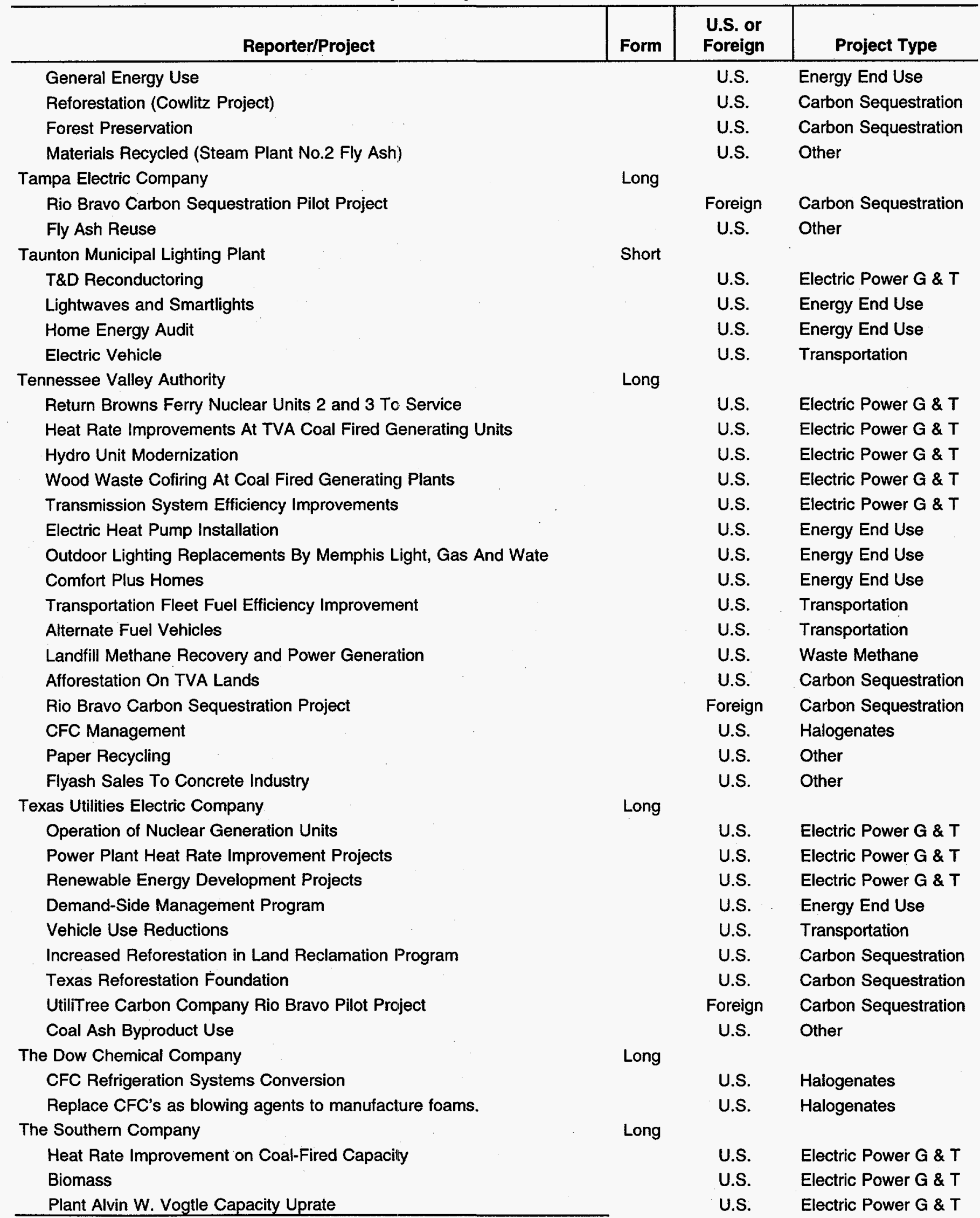




\begin{tabular}{|c|c|c|c|}
\hline Reporter/Project & Form & $\begin{array}{l}\text { U.S. or } \\
\text { Foreign }\end{array}$ & Project Type \\
\hline Plant Alvin W. Vogtle Nuclear Availability Improvements & & U.S. & Electric Power G \& T \\
\hline Bulk Power Transmission Improvements & & U.S. & Electric Power G \& T \\
\hline New Combustion Turbines & & U.S. & Electric Power G \& T \\
\hline Gas Capability at Watson $4-5$ & & U.S. & Electric Power G \& T \\
\hline Chevron Cogenerating Plant - Unit 5 & & U.S. & Cogeneration \\
\hline Demand Side Management & & U.S. & Energy End Use \\
\hline Transportation Research & & U.S. & Transportation \\
\hline Carbon Sequestration on Company Lands & & U.S. & Carbon Sequestration \\
\hline Trees for the Future & Long & & \\
\hline Guatemala & & Foreign & Carbon Sequestration \\
\hline Ghana & & Foreign & Carbon Sequestration \\
\hline Cameroon & & Foreign & Carbon Sequestration \\
\hline Belize & & Foreign & Carbon Sequestration \\
\hline Honduras & & Foreign & Carbon Sequestration \\
\hline India & & Foreign & Carbon Sequestration \\
\hline Nepal & & Foreign & Carbon Sequestration \\
\hline Kenya & & Foreign & Carbon Sequestration \\
\hline Panama & & Foreign & Carbon Sequestration \\
\hline Philippines & & Foreign & Carbon Sequestration \\
\hline Tchad & & Foreign & Carbon Sequestration \\
\hline Turkey & & Foreign & Carbon Sequestration \\
\hline Uganda & & Foreign & Carbon Sequestration \\
\hline Tucson Electric Power Company & Long & & \\
\hline Commercial DSM Programs & & U.S. & Energy End Use \\
\hline Residential DSM Programs & & U.S. & Energy End Use \\
\hline Travel Reduction Program & & U.S. & Transportation \\
\hline Trees for Tucson & & U.S. & Carbon Sequestration \\
\hline UtiliTree Program & & Foreign & Carbon Sequestration \\
\hline R-22 Recycling & & U.S. & Halogenates \\
\hline R-11 Recycling & & U.S. & Halogenates \\
\hline SF6 Recycling & & U.S. & Halogenates \\
\hline UNICOM (Commonwealth Edison Company) & Long & & \\
\hline Collins Station 123-Fuel Switch & & U.S. & Electric Power G \& T \\
\hline High Efficiency Transformers & & U.S. & Electric Power G \& T \\
\hline Windmill & & U.S. & Electric Power G \& T \\
\hline Energy Cooperative & & U.S. & Energy End Use \\
\hline UNICOM Thermal Cooling Plant & & U.S. & Energy End Use \\
\hline Aluminum Railroad Cars & & U.S. & Transportation \\
\hline Illinois Prairie Grass Plantings & & U.S. & Carbon Sequestration \\
\hline Unicom Thermal Cooling Plant & & U.S. & Halogenates \\
\hline Union Electric Company & Long & & \\
\hline Subtransmission Reconductoring & & U.S. & Electric Power G \& T \\
\hline Transformer Replacement " & & U.S. & Electric Power G \& T \\
\hline Waste Oil Heat Recovery & & U.S. & Electric Power G \& T \\
\hline Meramec Power Plant Control Upgrade & & U.S. & Electric Power G \& T \\
\hline Conversion to a dry flyash handling system. & & U.S. & Electric Power G \& T \\
\hline
\end{tabular}




\begin{tabular}{|c|c|c|c|}
\hline Reporter/Project & Form & $\begin{array}{l}\text { U.S. or } \\
\text { Foreign }\end{array}$ & Project Type \\
\hline Install adjustible speed fan drives replacing fixed speed & & U.S. & Electric Power G \& T \\
\hline Replaced motor-generator exciters with static exciter system & & U.S. & Electric Power G \& T \\
\hline Increased Nuclear generation & & U.S. & Electric Power G \& $T$ \\
\hline Sioux Plant Control Upgrade & & U.S. & Electric Power G \& T \\
\hline Demand Side Management Projects & & U.S. & Energy End Use \\
\hline Meramec Power Plant Lighting Upgrade & & U.S. & Energy End Use \\
\hline Street Light Conversion & & U.S. & Energy End Use \\
\hline EnviroTech Fund & & U.S. & Energy End Use \\
\hline Purchase of Light Weight Rail Cars & & U.S. & Transportation \\
\hline Union Electric Car Pool & & U.S. & Transportation \\
\hline Milam Landfill Methane Recovery & & U.S. & Waste Methane \\
\hline Green Leaf Project & & U.S. & Carbon Sequestration \\
\hline Flyash substitution for cement. & & U.S. & Other \\
\hline United Power Association & Long & & \\
\hline L-O Bucket Improvements & & U.S. & Electric Power G \& T \\
\hline Ultra-sonic and Helium leak detection improvements & & U.S. & Electric Power G \& T \\
\hline Cooling Tower Improvements & & U.S. & Electric Power G \& T \\
\hline Load Management & & U.S. & Energy End Use \\
\hline Ground-Source Heat Pumps & & U.S. & Energy End Use \\
\hline Conservation & & U.S. & Energy End Use \\
\hline Refuse Derived Fuel (RDF) Project & & U.S. & Waste Methane \\
\hline Coal Ash Programs & & U.S. & Other \\
\hline Utah Municipal Power Agency & Short & & \\
\hline Geothermal Generation & & U.S. & Electric Power G \& T \\
\hline In-House Conservation & & U.S. & Energy End Use \\
\hline Street Light Replacement & & U.S. & Energy End Use \\
\hline Tree Planting & & U.S. & Carbon Sequestration \\
\hline Vermont Public Power Supply Authority & Long & & \\
\hline Swanton Village Hydro Expansion & & U.S. & Electric Power G \& T \\
\hline Transmission and Distribution System Efficiency Improvements & & U.S. & Electric Power G \& T \\
\hline Residential Water Heating and Lighting Efficiency Program & & U.S. & Energy End Use \\
\hline Residential Appliance Disposal Program & & U.S. & Energy End Use \\
\hline Residential Low Income Weatherization Piggyback Program & & U.S. & Energy End Use \\
\hline Residential Mail Order Lighting Program & & U.S. & Energy End Use \\
\hline Farm Efficiency Program & & U.S. & Energy End Use \\
\hline Small Commercial Retrofit Program & & U.S. & Energy End Use \\
\hline Large Commercial and Industrial Audit Program & & U.S. & Energy End Use \\
\hline Equipment Replacement and Remodeling Program & & U.S. & Energy End Use \\
\hline Street and Area Lighting Efficiency Program & & U.S. & Energy End Use \\
\hline Act 250 New Construction Program & & U.S. & Energy End Use \\
\hline Waverly Light \& Power Company & Long & & \\
\hline Wind Turbine (Project 1 ) & & U.S. & Electric Power G \& T \\
\hline Hydro (Project 2) & & U.S. & Electric Power G \& T \\
\hline Distribution System Upgrade (Project 3) & & U.S. & Electric Power G \& T \\
\hline Low-Loss Transformers (Project 4) & & U.S. & Electric Power G \& T \\
\hline Energy End-Use Programs (Project 3.1) & & U.S. & Energy End Use \\
\hline
\end{tabular}




\begin{tabular}{|c|c|c|c|}
\hline Reporter/Project & Form & $\begin{array}{l}\text { U.S. or } \\
\text { Foreign }\end{array}$ & Project Type \\
\hline High-Pressure Sodium Lights (Project 3.2) & & U.S. & Energy End Use \\
\hline Energy Savings Due to Trees Forever (Project 3.3) & & U.S. & Energy End Use \\
\hline Electric Vehicle (Project 4.1) & & U.S. & Transportation \\
\hline Trees Forever (Project 8.1) & & U.S. & Carbon Sequestration \\
\hline Western Resources, Inc. & Long & & \\
\hline JEC2 Turbine Upgrade & & U.S. & Electric Power G \& T \\
\hline Wolf Creek Increased Capacity Rating & & U.S. & Electric Power G \& T \\
\hline Transformer Replacements & & U.S. & Electric Power G \& T \\
\hline Distribution Capacitor Additions & & U.S. & Electric Power G \& T \\
\hline LEC5 Upgrades & & U.S. & Electric Power G \& T \\
\hline HEC4 Cooling Tower Upgrade & & U.S. & Electric Power G \& T \\
\hline GEV1 Feedwater Heater Upgrade & & U.S. & Electric Power G \& T \\
\hline TEC8 Condenser Upgrade & & U.S. & Electric Power G \& T \\
\hline LAC2 Turbine Upgrade & & U.S. & Electric Power G \& T \\
\hline JEC1 Precipitator Intermittent Energization & & U.S. & Electric Power G \& T \\
\hline JEC2 Precipitator Intermittent Energization & & U.S. & Electric Power G \& T \\
\hline Photovoltaic Installations & & U.S. & Electric Power G \& T \\
\hline TEC8 Precipitator Intermittent Energization & & U.S. & Electric Power G \& T \\
\hline GEV2 Feedwater Controls Upgrade & & U.S. & Electric Power G \& T \\
\hline GEV2 Feedwater Heater Upgrade & & U.S. & Electric Power G \& T \\
\hline TEC7 Precipitator Intermittent Energization & & U.S. & Electric Power G \& T \\
\hline JEC3 Precipitator Intermittent Energization & & U.S. & Electric Power G \& T \\
\hline Wolf Creek Turbine Modifications & & U.S. & Electric Power G \& T \\
\hline Residential Conservation Use Rate DSM Program & & U.S. & Energy End Use \\
\hline Electrotechnologies Marketing & & U.S. & Energy End Use \\
\hline Conversion of Company Fleet Vehicles to Alternative Fuels & & U.S. & Transportation \\
\hline Purchase of Aluminum Rail Cars & & U.S. & Transportation \\
\hline Natural Gas Distribution System Replacement Program & & U.S. & Oil \& Gas Methane \\
\hline Natural Gas Transmission System Blowdown Reductions & & U.S. & Oil \& Gas Methane \\
\hline Rio Bravo Carbon Sequestration Pilot Project & & Foreign & Carbon Sequestration \\
\hline Coal Fly Ash Recycling & & U.S. & Other \\
\hline Wisconsin Electric Power Co. & Long & & \\
\hline Fossil plant heat rate improvements & & U.S. & Electric Power G \& T \\
\hline Hydro plant improvements and additions & & U.S. & Electric Power G \& T \\
\hline Transmission \& distribution system loss reductions & & U.S. & Electric Power G \& T \\
\hline Demand-side management energy efficiency programs & & U.S. & Energy End Use \\
\hline Vehicle conversion to dual fuel capability & & U.S. & Transportation \\
\hline Beneficial use of landfill methane & & U.S. & Waste Methane \\
\hline Rio Bravo Carbon Sequestration Pilot Project & & Foreign & Carbon Sequestration \\
\hline CFC-12 Recovery from Appliance Turn-In Program & & U.S. & Halogenates \\
\hline Fly ash substitution program & & U.S. & Other \\
\hline Wisconsin Power \& Light & Long & & \\
\hline Columbia 2 turbine blade Heat rate improvement & & U.S. & Electric Power G \& T \\
\hline Fuel Switching & & U.S. & Electric Power G \& T \\
\hline Columbia 1 turbine blade Efficiency improvements & & U.S. & Electric Power G \& T \\
\hline Edge 5 Excess Air Efficiency improvements & & U.S. & Electric Power G \& T \\
\hline
\end{tabular}


Table C2. 1995 Emissions Reduction Projects Reported

\begin{tabular}{|c|c|c|c|}
\hline Reporter/Project & Form & $\begin{array}{l}\text { U.S. or } \\
\text { Foreign }\end{array}$ & Project Type \\
\hline Columbia 2 economizer Efficiency improvements & & U.S. & Electric Power G \& T \\
\hline Columbia $1 \& 2$ Excess Air Efficiency improvements & & U.S. & Electric Power G \& T \\
\hline Tire Derived Fuel Generation & & U.S. & Electric Power G \& T \\
\hline Transmission line improvements & & U.S. & Electric Power G \& T \\
\hline Energy end use projects-Electric & & U.S. & Energy End Use \\
\hline Energy end use-Gas & & U.S. & Energy End Use \\
\hline Verona Landfill Methane & & U.S. & Waste Methane \\
\hline Modified Forest Management & & U.S. & Carbon Sequestration \\
\hline Conservation tillage & & U.S. & Carbon Sequestration \\
\hline Forest preservation & & U.S. & Carbon Sequestration \\
\hline Afforestation & & U.S. & Carbon Sequestration \\
\hline Habitat Restoration & & U.S. & Carbon Sequestration \\
\hline Wisconsin Public Power Inc. & Short & & \\
\hline Boswell Heat Rate Reduction & & U.S. & Electric Power G \& T \\
\hline Kaukana CT I\&C Upgrade & & U.S. & Electric Power G \& T \\
\hline Dispatch Change - Menasha Unit & & U.S. & Electric Power G \& T \\
\hline Residential Appliances & & U.S. & Energy End Use \\
\hline Commercial Industrial Farm Program & & U.S. & Energy End Use \\
\hline Street Lighting & & U.S. & Energy End Use \\
\hline Tree Power 1991 Plantings (5 Year Olds) & & U.S. & Carbon Sequestration \\
\hline Tree Power 1992 Plantings (4 Year Olds) & & U.S. & Carbon Sequestration \\
\hline Tree Power 1993 Plantings ( 3 year Olds) & & U.S. & Carbon Sequestration \\
\hline Tree Power 1994 Plantings (2 year olds) & & U.S. & Carbon Sequestration \\
\hline Tree Power 1995 Plantings ( 1 Year Olds) & & U.S. & Carbon Sequestration \\
\hline Energy Education & & U.S. & Other \\
\hline Wisconsin Public Service Corporation & Long & & \\
\hline Transmission Line Construction & & U.S. & Electric Power G \& T \\
\hline Demand Side Management Programs & & U.S. & Energy End Use \\
\hline Afforestation and Reforestation Efforts & & U.S. & Carbon Sequestration \\
\hline Zahren Alternative Power Corp. & Short & & \\
\hline Landfill Gas Recovery for Energy, Oceanside & & U.S. & Waste Methane \\
\hline Landfill Gas Recovery for Energy, SPSA & & U.S. & Waste Methane \\
\hline Landfill Gas Recovery for Energy, Smithtown & & U.S. & Waste Methane \\
\hline Landfill Gas Recovery for Energy, Oyster Bay & & U.S. & Waste Methane \\
\hline Landfill Gas Recovery for Energy, Hamm's & & U.S. & Waste Methane \\
\hline Landfill Gas Recovery for Energy, Bondi's & & U.S. & Waste Methane \\
\hline Landfill Gas Recovery for Energy, Intervale & & U.S. & Waste Methane \\
\hline Landfill Gas Recovery for Energy, Amity Facili & & U.S. & Waste Methane \\
\hline Landfill Gas Recovery for Energy, Onondaga & & U.S. & Waste Methane \\
\hline Landfill Gas Recovery for Energy, Dunbarton & & U.S. & Waste Methane \\
\hline Zeeland Board of Public Works & Short & & \\
\hline Distribution Line Improvements & & U.S. & Electric Power G \& T \\
\hline General Tranmission \& Distribution & & U.S. & Electric Power G \& T \\
\hline General Carbon Sequestration & & U.S. & Carbon Sequestration \\
\hline
\end{tabular}


Table C3. Reporting Entities by Type of Form and Organization, Data Years 1994 and 1995 (Number of Forms Received)

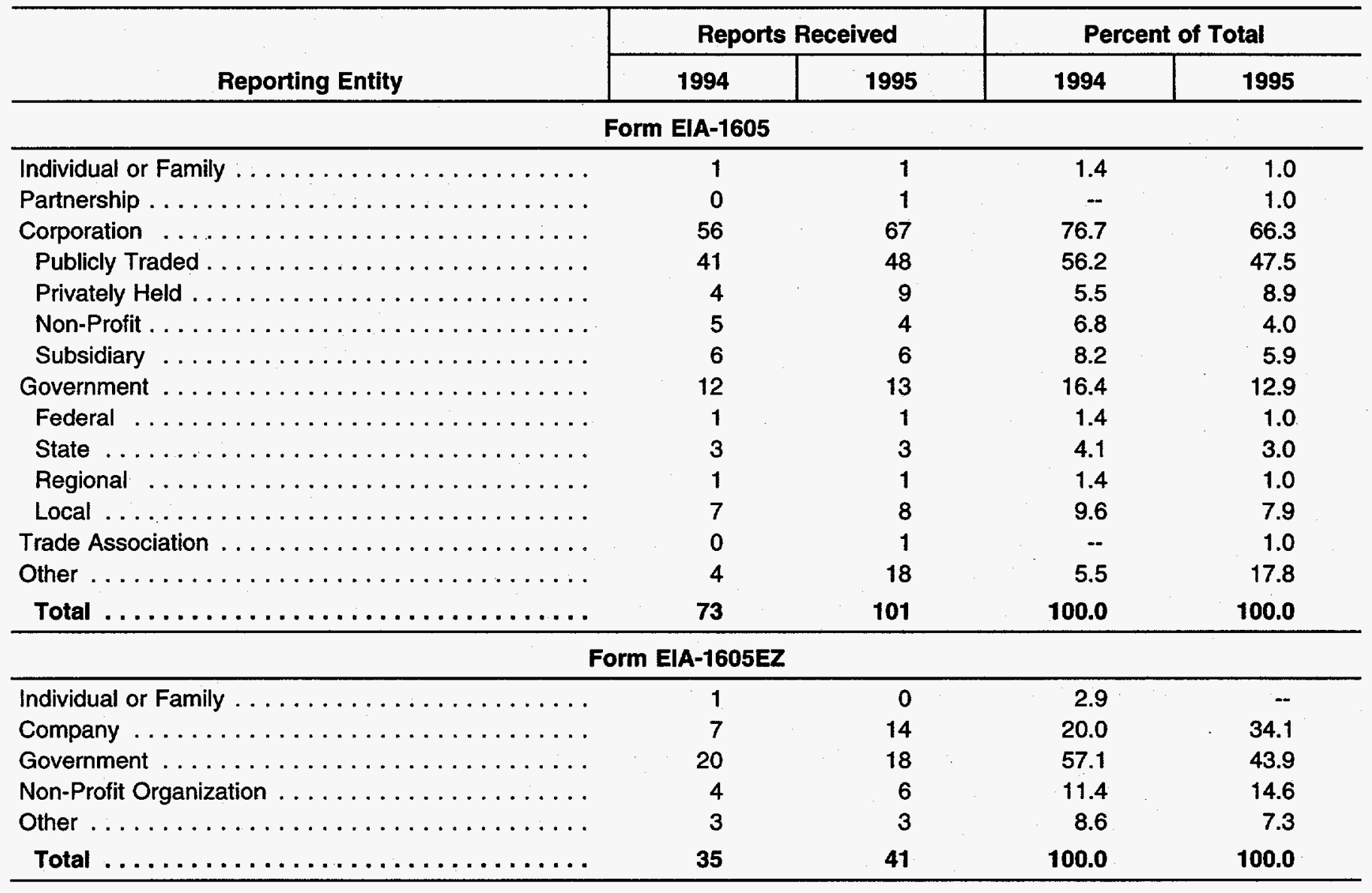

Source: Energy Information Administration, Forms EIA-1605 and EIA-1605EZ, "Voluntary Reporting of Greenhouse Gases."

Table C4. Summary of Reports Received by Schedule, Data Years 1994 and 1995 (Number of Reports Received)

\begin{tabular}{|c|c|c|c|c|c|c|}
\hline Type of Information & \multicolumn{2}{|c|}{ Form EIA-1605 } & \multicolumn{2}{|c|}{ Form EIA-1605EZ } & \multicolumn{2}{|c|}{ Total } \\
\hline Emissions Reductions Projects (Schedule II) & 64 & 88 & 35 & 41 & 99 & 129 \\
\hline Entity-Wide Emissions or Reductions (Schedule III) . . . . . & 40 & 51 & -- & -- & 40 & 51 \\
\hline Commitments to Reduce Future Emissions (Schedule IV) & 42 & 59 & -- & -- & 42 & 59 \\
\hline
\end{tabular}

Note: The totals are smaller than the sums of the numbers for each type of information, because most reporters provided information on more than one schedule.

Source: Energy Information Administration, Forms EIA-1605 and EIA-1605EZ, "Voluntary Reporting of Greenhouse Gases." 
Table C5. Distribution of Projects Reported by Project Type Category, Data Years 1994 and 1995

\begin{tabular}{|c|c|c|c|c|}
\hline \multirow[b]{2}{*}{ Project Type } & \multicolumn{2}{|c|}{ Number of Reporters } & \multicolumn{2}{|c|}{ Number of Projects } \\
\hline & 1994 & 1995 & 1994 & 1995 \\
\hline Electricity Generation, Transmission, and Distribution & 71 & 86 & 223 & 292 \\
\hline$\ldots \ldots \ldots \ldots \ldots \ldots \ldots \ldots$ & 5 & 8 & 7 & 11 \\
\hline Energy End Use & 77 & 91 & 208 & 276 \\
\hline Transportation & 26 & 34 & 33 & 50 \\
\hline Waste Treatment and Disposal (Methane) & 12 & 20 & 27 & 39 \\
\hline Agriculture (Methane and Nitrous Oxide) & 2 & 2 & 3 & 3 \\
\hline Oil and Natural Gas Systems and Coal Mining (Methane) & 8 & 10 & 13 & 16 \\
\hline Carbon Sequestration & 40 & 62 & 78 & 199 \\
\hline Halogenated Substances & 13 & 18 & 15 & 22 \\
\hline Other Emissions Reductions & 33 & 45 & 38 & 59 \\
\hline All Categories.. & 99 & 129 & 645 & 967 \\
\hline Did Not Report Projects & 9 & 13 & -- & -- \\
\hline Total, All Reporters . . . . & 108 & 142 & 645 & 967 \\
\hline
\end{tabular}

Note: The total numbers of reporters are smaller than the sums of the numbers of reporters for each project type, because most reporters provided information on more than one project.

Source: Energy Information Administration, Forms EIA-1605 and EIA-1605EZ, "Voluntary Reporting of Greenhouse Gases."

Table C6. Distribution of Projects Reported by Project Type Category and Reporting Form, Data Year 1995

\begin{tabular}{|c|c|c|c|c|c|c|}
\hline \multirow[b]{2}{*}{ Project Type } & \multicolumn{2}{|c|}{ Form EIA-1605 } & \multicolumn{2}{|c|}{ Form EIA-1605EZ } & \multicolumn{2}{|c|}{ Total } \\
\hline & $\begin{array}{l}\text { Number of } \\
\text { Reporters }\end{array}$ & $\begin{array}{l}\text { Number of } \\
\text { Projects }\end{array}$ & $\begin{array}{l}\text { Number of } \\
\text { Reporters }\end{array}$ & $\begin{array}{l}\text { Number of } \\
\text { Projects }\end{array}$ & $\begin{array}{l}\text { Number of } \\
\text { Reporters }\end{array}$ & $\begin{array}{l}\text { Number of } \\
\text { Projects }\end{array}$ \\
\hline $\begin{array}{l}\text { Electricity Generation, Transmission, and } \\
\text { Distribution } \ldots \ldots \ldots \ldots \ldots \ldots \ldots \ldots \ldots\end{array}$ & 62 & 248 & 24 & 44 & 86 & 292 \\
\hline Cogeneration & 7 & 10 & 1 & 1 & 8 & 11 \\
\hline Energy End Use & 63 & 221 & 28 & 55 & 91 & 276 \\
\hline Transportation & 28 & 40 & 6 & 10 & 34 & 50 \\
\hline Waste Treatment and Disposal (Methane) . . & 16 & 23 & 4 & 16 & 20 & 39 \\
\hline Agriculture (Methane and Nitrous Oxide) & 2 & 3 & 0 & 0 & 2 & 3 \\
\hline $\begin{array}{l}\text { Oil and Natural Gas Systems and Coal } \\
\text { Mining (Methane) } \ldots \ldots \ldots \ldots \ldots \ldots\end{array}$ & 9 & 11 & 1 & 5 & 10 & 16 \\
\hline Carbon Sequestration & 44 & 175 & 18 & 24 & 62 & 199 \\
\hline Halogenated Substances . . & 17 & 21 & 1 & 1 & 18 & 22 \\
\hline Other Emissions Reductions & 35 & 44 & 10 & 15 & 45 & 59 \\
\hline Total (All Project Types) $\ldots \ldots \ldots \ldots \ldots$. . . & 88 & 796 & 41 & 171 & 129 & 967 \\
\hline
\end{tabular}

Note: The total numbers of reporters are smaller than the sums of the numbers of reporters for each project type, because most reporters provided information on more than one project.

Source: Energy Information Administration, Forms EIA-1605 and EIA-1605EZ, "Voluntary Reporting of Greenhouse Gases." 
Table C7. Affiliation of Reported Emissions Reduction and Carbon Sequestration Projects with Voluntary Programs by Project Type Category, Data Year 1995

\begin{tabular}{|c|c|c|c|c|c|c|}
\hline \multirow[b]{2}{*}{ Voluntary Program } & \multirow[b]{2}{*}{$\begin{array}{l}\text { Number of } \\
\text { Reporters }\end{array}$} & \multicolumn{4}{|c|}{ Project Type } & \multirow[b]{2}{*}{$\begin{array}{c}\text { Total } \\
\text { Number of } \\
\text { Projects }\end{array}$} \\
\hline & & Electricity & $\begin{array}{l}\text { Energy } \\
\text { End Use }\end{array}$ & $\begin{array}{l}\text { Carbon } \\
\text { Sequestra- } \\
\text { tion }\end{array}$ & $\begin{array}{l}\text { Other } \\
\text { Emissions } \\
\text { Reductions }\end{array}$ & \\
\hline Climate Challenge..$\ldots \ldots \ldots$ & 97 & 264 & 221 & 107 & 129 & 721 \\
\hline Coalbed Methane Outreach ..... & 1 & 0 & 0 & 0 & 1 & 1 \\
\hline Climate Wise Recognition & 5 & 0 & 8 & 0 & 5 & 13 \\
\hline Energy Star Building $\ldots \ldots \ldots \ldots$ & 1 & 0 & 8 & 0 & 0 & 8 \\
\hline Energy Star Computers . . . . . . . & 1 & 0 & 1 & 0 & 0 & 1 \\
\hline Energy Star Transformers ...... & 5 & 5 & 0 & 0 & 0 & 5 \\
\hline Green Lights . . . . . . . . . . & 18 & 0 & 29 & 0 & 0 & 29 \\
\hline Landfill Methane Outreach . . . . . . & 6 & 0 & 0 & 0 & 8 & 8 \\
\hline Motor Challenge $\ldots \ldots \ldots \ldots$ & 3 & 0 & 4 & 0 & 0 & 4 \\
\hline Natural Gas STAR $\ldots \ldots \ldots \ldots$ & 5 & 0 & 0 & 0 & 9 & 9 \\
\hline Other Federal, State, and Local . . & 5 & 0 & 3 & 3 & 0 & 6 \\
\hline USIJI & 17 & 0 & 0 & 19 & 0 & 19 \\
\hline WasteWi\$e .............. & 3 & 0 & 1 & 0 & 2 & 3 \\
\hline Other $\ldots \ldots \ldots \ldots \ldots \ldots \ldots$ & 9 & 1 & 4 & 2 & 8 & 15 \\
\hline None Specified & 33 & 26 & 23 & 78 & 49 & 176 \\
\hline Total $\ldots \ldots \ldots \ldots \ldots \ldots$ & 129 & 292 & 276 & 199 & 200 & 967 \\
\hline
\end{tabular}

USIJI = U.S. Initiative on Joint Implementation.

Note: The total numbers are smaller than the sums of the numbers for each voluntary program type, because some projects were affiliated with more than one voluntary program and most reporters reported on more than one project.

Source: Energy Information Administration, Forms EIA-1605 and EIA-1605EZ, "Voluntary Reporting of Greenhouse Gases." 



\section{Glossary}

Afforestation: Planting of new forests on lands that have not been recently forested.

Anaerobic lagoon: A liquid-based manure management system, characterized by waste residing in water to a depth of at least 6 feet for a period ranging between 30 and 200 days.

Associated gas: Natural gas found mixed with crude oil in underground reservoirs, released as a byproduct of oil production.

Baseline period: The years 1987 through 1990 for which entity-level emissions may be reported.

Biofuels: Organic materials, such as wood, waste, and alcohol, burned for energy purposes.

Biogas: A mixture of carbon dioxide and methane produced through bacterial action.

Biomass: Materials that are biological in origin, including organic material (both living and dead) from above and below ground, e.g., trees, crops, grasses, tree litter, roots, and animals and animal waste.

British thermal unit (Btu): A common unit used in measuring energy, equal to the amount of heat needed to raise the temperature of 1 pound of water by $1^{\circ} \mathrm{F}$.

Carbon sink: A reservoir that absorbs or takes up released carbon. Vegetation and soils are common carbon sinks.

Chlorofluorocarbons (CFCs): A family of inert, nontoxic, and easily liquefied chemicals used in refrigeration, air conditioning, packaging, and insulation, or as solvents or aerosol propellants. Because they are nonreactive, they drift into the upper atmosphere, where they are disassociated by solar radiation and where their components destroy ozone.

Cogeneration: The sequential use of energy to generate electricity and another form of useful thermal energy, such as heat or steam.

Commercial-scale: Application of a demonstrated technology at a cost-effective scale.

Commitment: An expressed intention to undertake an action or actions that will reduce greenhouse gas emissions, increase carbon sequestration, or achieve a stated emissions goal.
Conversion factor: A unique value used to convert one unit (e.g., acres) to another appropriate unit (e.g., hectares).

Deforestation: The removal of forest stands.

Emission coefficient/factor: A unique value for scaling emissions to activity data in terms of a standard rate of emissions per unit of activity (e.g., pounds of carbon dioxide emissions per barrel of fossil fuel consumed).

Emissions: Anthropogenic (human-caused) releases of greenhouse gases to the atmosphere (e.g., the release of carbon dioxide during fuel combustion).

Emissions, direct: Emissions from sources owned (wholly or in part) or leased by an entity.

Emissions, fugitive: Emissions that are released inadvertently or accidentally from a controlled or closed system, such as natural gas pipelines.

Emissions, indirect: Emissions from sources not owned or leased by an entity that occur, wholly or in part, as a result of its activities.

Emissions reduction: A decrease in annual greenhouse gas emissions.

Energy conservation: Activities that reduce end-use demand for energy by reducing the service demanded.

Entity: For the purposes of the Voluntary Reporting Program, an individual or organization that is a legal U.S. person (e.g., a U.S. citizen, resident alien, company, organization or group incorporated under or recognized by U.S. law; or a Federal, State, or local government agency).

Entity boundary: Conceptually, a line drawn to encompass the emissions sources and sinks to be evaluated in an entity-level report. An entity boundary should include all the emissions sources and sinks owned (wholly or in part) or leased by the entity, and, to the extent possible, other emissions sources and sinks affected by the entity's activities.

Entity-level reporting: The reporting of greenhouse gas emissions, emission reductions, and carbon sequestration for an entire entity.

Estimation method: The techniques, including key assumptions and data sources, used by the reporter to 
derive the reported emissions, emission reductions, or sequestration.

Foreign activities: All actions outside of the United States, its territories, and trusts.

Fossil fuel: A hydrocarbon fuel, such as petroleum, derived from living matter of a previous geologic time.

Fuel cycle: The entire set of sequential processes or stages involved in the utilization of fuel, including extraction, transformation, transportation, and combustion. Emissions generally occur at each stage of the fuel cycle.

Fuel switching: The substitution of one type of fuel for another. The fuel substitution may be either temporary (as in the case of a power plant that temporarily switches from coal to natural gas) or permanent (as in the case of a fleet operator who replaces gasolinepowered automobiles with electric cars).

Fugitive emissions: See Emissions, fugitive.

Gob: A zone of rubble created when the roof of a coal mine collapses behind the mining operations.

Greenhouse effect: A popular term used to describe the roles of water vapor, carbon dioxide, and other trace gases in keeping the Earth's surface warmer than it would otherwise be. These radiatively active gases are relatively transparent to incoming shortwave radiation but are relatively opaque to outgoing long-wave radiation. The latter radiation, which would otherwise escape to space, is trapped by these gases within the lower levels of the atmosphere. The subsequent reradiation of some of the energy back to the Earth maintains surface temperatures higher than they would be if the gases were absent. There is concern that increasing concentrations of greenhouse gases, including carbon dioxide, methane, and man-made halogenated substances, may enhance the greenhouse effect and cause global climate change.

Greenhouse gases: Those gases, such as water vapor, carbon dioxide, tropospheric ozone, nitrous oxide, and methane that are transparent to solar radiation but opaque to long-wave radiation, thus preventing longwave radiation energy from leaving the atmosphere. The greenhouse gases covered by the Voluntary Reporting Program are (1) carbon dioxide $\left(\mathrm{CO}_{2}\right)$, (2) methane $\left(\mathrm{CH}_{4}\right)$, (3) nitrous oxide $\left(\mathrm{N}_{2} \mathrm{O}\right)$, and (4) halogenated substances. Increasing levels of greenhouse gases in the atmosphere may contribute to an increase in average global temperatures, resulting in adverse climate changes.

Halogenated substance: A volatile compound containing halogens, such as chlorine, fluorine, or bromine.
Horizon year: The year in which a commitment to reduce greenhouse gas emissions or increase sequestration (reported on Schedule IV) is expected to be met.

Intergovernmental Panel on Climate Change (IPCC): A panel established jointly in 1988 by the World Meteorological Organization and the United Nations Environment Program to assess scientific information relating to climate change and to formulate realistic response strategies.

Life cycle: $A$ progression of a product through its service life. For most products, emissions and energyconsuming characteristics will be altered as they age.

Longwall mining: A technique of underground mining in which a cutting machine is pulled back and forth along a panel of coal 300 to 1,000 feet wide and as much as 2 miles long. As the panel is cut, the broken coal is removed by a conveyor, and movable roof supports advance, allowing the roof in mined-out areas to collapse.

Manure management: The method used to dispose of the solid waste produced by livestock and poultry.

Municipal solid waste: Residential solid waste and some nonhazardous commercial, institutional, and industrial wastes.

Ozone: A molecule made up of three atoms of oxygen. In the stratosphere, it occurs naturally and provides a protective layer shielding the Earth from harmful ultraviolet radiation. In the troposphere, it is a chemical oxidant and major component of photochemical smog.

Photosynthesis: The manufacture of carbohydrates by plants from carbon dioxide and water in the presence of chlorophyll, with sunlight as the energy source. In this process, carbon is sequestered and oxygen is released.

Pilot project: A small-scale trial designed to test or demonstrate the efficiency or efficacy of a project.

Project: An action undertaken to reduce greenhouse gas emissions or sequester carbon.

Project boundary: Conceptually, a line drawn to encompass the emissions sources and sinks affected by a project. A project boundary should include all the significant and quantifiable effects of the project.

Project ID code: $A$ unique code assigned by the Energy Information Administration to a reported project for tracking purposes.

Project-level reporting: Reporting on emissions reductions or carbon sequestration achieved as a result of a specific action or group of actions. 
Reconductoring: Replacement of existing conductors with large-diameter conductors to reduce line losses. Conductors (including feeders and transmission lines). are a major source of transmission and distribution system losses. In general, the smaller the diameter of the conductor, the greater its resistance to the flow of electric current, and the greater the consequent line losses.

Reference case: The emissions level to which the current actual emissions levels is compared when calculating emissions reductions.

Reference case, basic: A reference case using actual historical emissions or sequestration values.

Reference case, modified: A reference case using projected emissions or sequestration values, representing the emissions level that would have occurred in the absence of the reduction or sequestration efforts.

Reforestation: Replanting of forests on lands that have recently been harvested.

Reporter: An entity (see definition above) completing either Form EIA-1605 or Form EIA-1605EZ and submitting it to the Energy Information Administration.
Room and pillar mining: The most common method of underground coal mining, in which the mine roof is supported by coal pillars left at regular intervals.

Sequestered carbon: Carbon that is removed from the atmosphere and retained in a carbon sink (such as a growing tree) or in soil.

Sequestration: The fixation of atmospheric carbon dioxide in a carbon sink through biological or physical processes, such as photosynthesis.

Sink: See carbon sink.

Third-party reporter: An authorized party that submits a report on behalf of two or more entities which have engaged in emissions-reducing or sequestrationincreasing activities. Possible third-party reporters include trade associations reporting on behalf of members that have undertaken reduction projects.

Vhar metering: Phase shifters on watthour meters that measure reactive volt ampere hours or varhours.

Watt (W): A common metric unit used in measuring power (the rate at which work is done), defined as 1 Joule per second and equivalent to 3.412 Btu per hour. 

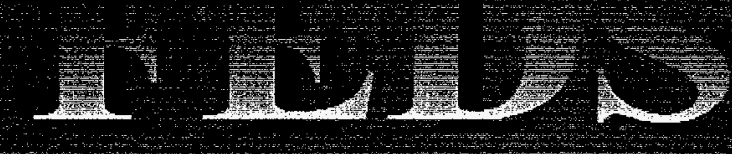

15 祭

章

\section{Window on the \\ Spectrum of Federal Statistics}

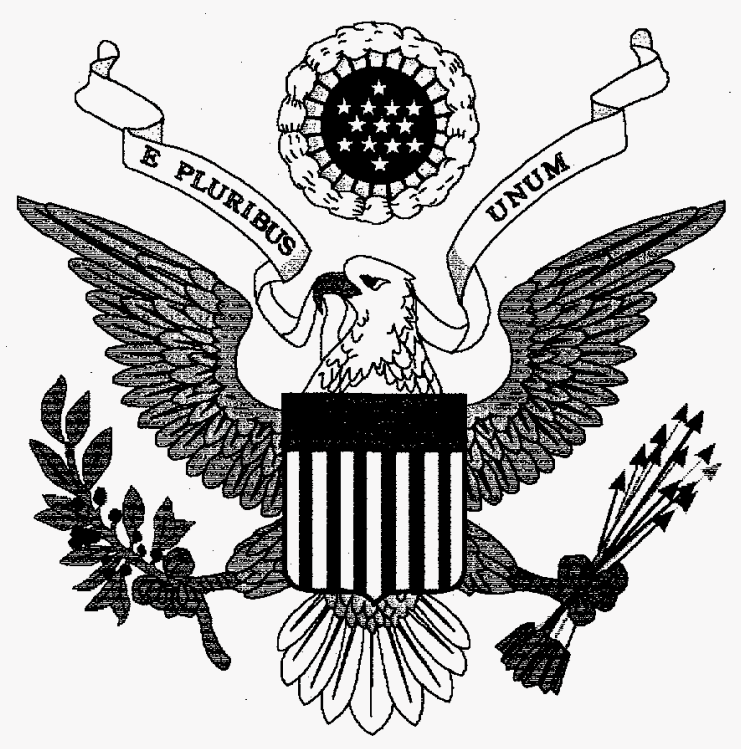

www.fedstats.gov

Easy Access to the Full Range of

Federal Statistics Available for Public Use 